

João Rafael Coelho Cursino dos Santos

\title{
A FESTA dO DIVINO de SÃO LUIZ DO PARAITINGA: O DESAFIO DA CULTURA POPULAR NA CONTEMPORANEIDADE
}

Orientadora: Profa. Dra . Marina de Mello e Souza

\author{
MESTRADO FFLCH/USP \\ São Paulo \\ 2008
}




\author{
Universidade de São Paulo \\ FACULDADE DE FILOSOFIA LETRAS E CIÊNCIAS HUMANAS
}

DEPARTAMENTO DE HISTÓRIA

PROGRAMA DE PÓS-GRADUAÇÃO EM HISTÓRIA SOCIAL

\title{
A FESTA DO DIVINO DE SÃO LUIZ DO PARAITINGA: O \\ DESAFIO DA CULTURA POPULAR NA CONTEMPORANEIDADE
}

João Rafael Coelho Cursino dos Santos

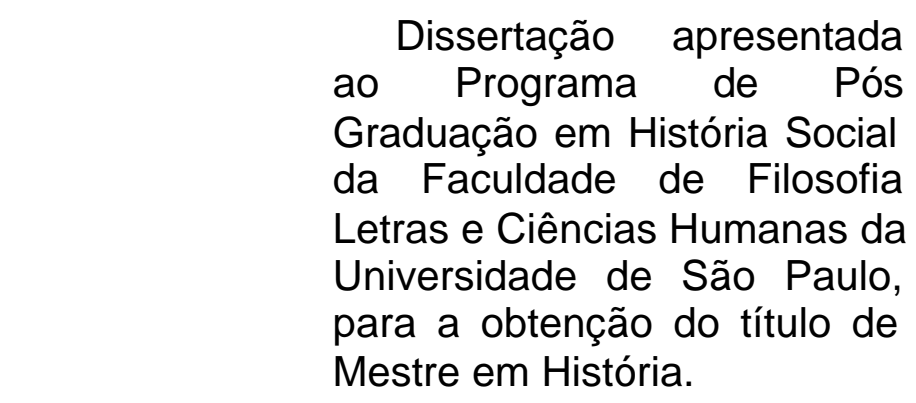

Orientadora: Prof ${ }^{a}$.Dr ${ }^{\text {a }}$. Marina de Mello e Souza

São Paulo 
Autorizo a reprodução e divulgação total ou parcial deste trabalho, por qualquer meio convencional ou eletrônico, para fins de estudo e pesquisa, desde que citada a fonte.

Serviço de Biblioteca e Documentação da Faculdade de Filosofia, Letras e Ciências Humanas da Universidade de São Paulo

Santos, João Rafael Coelho Cursino dos
S237 A Festa do Divino de São Luiz de Paraitinga : o desafio da cultura popular na contemporaneidade / João Rafael Coelho Cursino dos Santos ; orientadora Marina de Mello e Souza. -- São Paulo, 2008.

210 f. : il.

Dissertação (Mestrado - Programa de Pós-Graduação em História Social. Área de concentração: História Social) - Departamento de História da Faculdade de Filosofia, Letras e Ciências Humanas da Universidade de São Paulo.

1. Cultura popular - São Luiz do Paraitinga (SP). 2. Festas religiosas - São Luiz do Paraitinga (SP). 3. Religiosidade popular. I. Título. 
Aos meus pais,

João Bosco e Ana Maria

e a toda população de São

Luiz do Paraitinga. 


\section{$\underline{\text { Agradecimentos }}$}

Fica difícil expressar a gratidão e apontar o grande número de pessoas e órgãos que foram fundamentais na elaboração deste trabalho. Seria impossível citar todos neste espaço, fica, entretanto, o profundo agradecimento a todas as pessoas que contribuíram, direta ou indiretamente, para a elaboração desta pesquisa. Em especial:

- Toda minha família, especialmente meus pais João Bosco e Ana Maria, pelo constante apoio e incentivo;

- Todos professores e colegas de estudo da Universidade de São Paulo, especialmente minha orientadora prof. ${ }^{\mathrm{a}} \mathrm{dr}^{\mathrm{a}}$. Marina de Mello e Souza. Uma orientação que transcendeu as discussões deste trabalho servindo como guia para toda a minha vida;

- Meus colegas de trabalho pela constante paciência com minhas ausências e inquietações causadas pela pesquisa;

- Aos funcionários da secretaria de Pós Graduação da FFLCH/USP pelo constante e eficiente atendimento;

- Ao prof. ${ }^{o}$ dr. ${ }^{\circ}$ Nicolau Sevcenko e ao prof. ${ }^{o}$ dr. ${ }^{o}$ José Geraldo Vinci de Moraes pelas contribuições fundamentais da banca de qualificação;

- A prof ${ }^{a}$. Cássia Moradei pela preciosa ajuda na revisão ortográfica;

- A todos os amigos e familiares, especialmente Luciane Bittencourt, que sempre contribuíram lendo trechos deste trabalho, questionando e fazendo-o crescer;

- Aos membros da Banda Estrambelhados sempre solícitos em ajudar e respeitando minhas ausências dos compromissos musicais em determinados momentos da pesquisa;

- A todos funcionários do Arquivo do Estado de São Paulo, CAPH/USP, Museu Dr. Oswaldo Cruz, Prefeitura Municipal de São Luiz do Paraitinga, Biblioteca Central da FFLCH/USP e todos outros museus, arquivos, instituições e bibliotecas pesquisados;

- De maneira ainda mais especial, a todos os membros da cultura popular que a pesquisa permitiu aproximação. A concepção de mundo que os cerca me fez enxergar a vida de uma maneira totalmente diferente. 
“ (...) Distingo- agora, o casario esbranquiçado, os velhos telhados e o larguinho... rodeado de sobradões antigos. Uma ou outra parede de azulejo.

Histórias do passado! nenhuma casa nova.

Olhos úmidos, e a Cidade à minha frente, aumentando... Sem sentir, estou em cima do rio

Atravessando a ponte nova!

Ah!, a velha ponte esburacada d'outrora, Que, em menino eu pensava, ser a fronteira que separava a minha Cidade, da terra dos fantasmas! Não errava.

Hoje sei que a ponte nova Que ali está, Na saída, da minha cidadezinha,

é a fronteira impediosa, que separa dois mundos grandes.

Quanta coisa me assalta! Passado distante, saudades de menino!"

Aziz Nacib Ab'Sáber Janeiro de 1946 


\section{$\underline{\text { Índice de fotos }}$}

Foto 01 -Fiéis empunham suas bandeiras dentro do Império do Divino

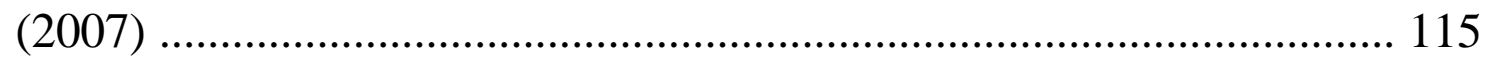

Foto 02 - Membro da folia do Divino carrega a bandeira da festa (2007) 118

Foto 03 - Benção do afogado pelo Monsenhor Eugênio (1994)............. 121

Foto 04 - Saída da procissão do Divino de 2007 ..................................... 122

Foto 05 - Rei e Rainha do Congo na festa de 2005 ................................ 126

Foto 06 - População saboreando o afogado (2008)................................ 164

Foto 07 - Centro histórico de São Luiz do Paraitinga lotado no Carnaval 2008 . 185

Foto 08 - Desfile dos bonecões do Carnaval 2008 de São Luiz do Paraitinga. 187 


\section{$\underline{\text { Indice de tabelas }}$}

Tabela 01 - Produção cafeeira em arrobas vale do Paraíba (1836)...........65

Tabela 02 - Lista Nominativa anual de habitantes da vila de São Luiz do

Paraitinga para o ano de 1801 (Roberto da Silva Leme) .67

Tabela 03 - População de São Luiz do Paraitinga (1836-1940) ................71

Tabela 04 - Orçamento de arrecadação da prefeitura municipal de São

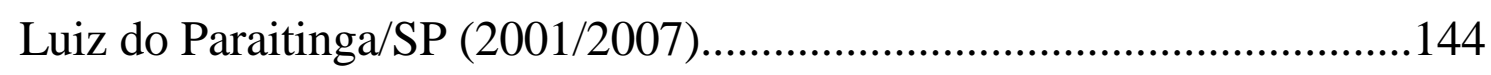

Tabela 05 - Domicílios permanentes e de uso ocasional em São Luiz do

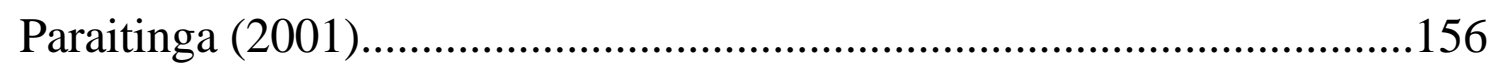




\section{SUMÁRIO}

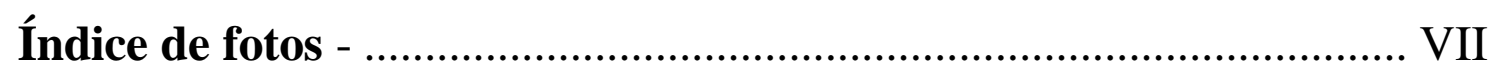



Resumo - ............................................................................ XII

Abstract $-\ldots \ldots \ldots \ldots \ldots \ldots \ldots \ldots \ldots \ldots \ldots \ldots \ldots \ldots \ldots \ldots \ldots \ldots \ldots \ldots \ldots \ldots \ldots \ldots \ldots \ldots \ldots \ldots \ldots \ldots \ldots \ldots \ldots . . . \mathrm{XIII}$

Capítulo I- O CAMINHO TEÓRICO ESCOLHIDO.....................................

1.1 Apresentação.................................................................................. 01

1.2 Discussão sobre o conceito de popular:-...…………………………...... 04

1.3 A questão fundamental da memória ...................................................16

1.4 A festa do Divino Espírito Santo de São Luiz do Paraitinga como representação de uma cultura diferenciada...................................................20

1.5 As indagações que nortearam a seleção das fontes $\mathrm{e}$ a

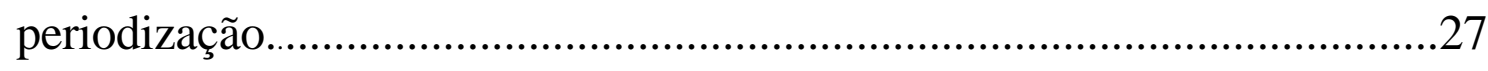

Capítulo II- A IMPORTÂNCIA DA HISTÓRIA LOCAL NAS MANIFESTAÇÕES POPULARES DE SÃO LUIZ DO PARAITINGA .38

2.1. As tropas do ouro e o papel de São Luiz do Paraitinga como entreposto comercial do vale do Paraíba.....................................................................42

2.2. A fundação de uma nova cidade...........................................................52

2.3. - Um "novo tempo": o desenvolvimento das lavouras cafeeiras no vale



2.4. A "invenção" do poderio cafeeiro luizense...........................................64

2.5 A economia local: da derrocada do café às potencialidades do turismo. .69 
Capítulo III- A HISTÓRIA DA FESTA DO DIVINO DE SÃO LUIZ DO PARAITINGA E SUAS CARACTERÍSTICAS PECULIARES................76

3.1. Os cultos pagãos incorporados pelo catolicismo nas festas do Divino Espírito Santo. .78

3.2. As principais influências da Festa do Divino brasileira .................... 84

3.3. A história da Festa do Divino em São Luiz do Paraitinga.................. 91

3.4. A festa do Divino Espírito Santo de São Luiz do Paraitinga como ponto de sociabilidade primordial no município. 100

3.5. A importância da folia na festa do Divino de São Luiz do Paraitinga .106

3.6 O conceito de reciprocidade e o dia-a-dia da festa do Divino luizense. 114

3.7 A proeminência do rei do Congo na festa do Divino de São Luiz do Paraitinga 123

3.8 Os conflitos entre a Igreja Católica e a religiosidade popular. 131

- Capítulo IV- A RELAÇÃO DA FESTA DO DIVINO DE SÃO LUIZ DO PARAITINGA COM AS ATUAIS TRANSFORMAÇÕES NA SOCIEDADE LOCAL 139

4.1. A situação econômica atual da cidade e o êxodo de mão-deobra 142

4.2. Uma cidade cada vez menos isolada 145

4.3. Riscos trazidos pelo turismo e o surgimento da população de "segunda residência". 150

4.4. As novas tendências religiosas locais e o impacto na festa do Divino 157

4.5. O crescimento da interferência do poder público nas festas atuais. 162 
- Capítulo V- CONSIDERAÇÕES FINAIS: O SURGIMENTO DE NOVAS MANIFESTAÇÕES POPULARES NA CIDADE....................171

5.1. O exemplo da música popular luizense.................................................174

5.2. O carnaval das marchinhas de São Luiz do Paraitinga........................183

5.3. O "Raloim Caipira” e as últimas considerações..................................190



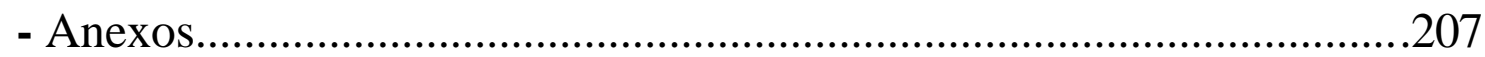




\section{$\underline{\text { Resumo }}$}

A festa do Divino Espírito Santo de São Luiz do Paraitinga, estado de São Paulo, mantém, na atualidade, muitos elementos típicos da cultura popular, destacadamente a constituição de uma fortalecida identidade local, a presença da oralidade e uma memória pautada em padrões coletivos e elementos altamente simbólicos e agregadores. Através da análise da história desta festa foi possível perceber a grande capacidade de plasticidade e transformação da cultura popular, e deparar-se com novas possibilidades de interpretação tanto da história local, como do espaço das manifestações populares na sociedade contemporânea brasileira.

Palavras-chaves: festa do Divino, cultura popular, memória coletiva e identidade. 


\begin{abstract}
$\underline{\text { Abstract }}$
The festivity of the Holy Spirit at São Luiz do Paraitinga, in the state of São Paulo, keeps nowadays many typical elements of the popular culture, specially de constitution of a strong local identity, the presence of orality and a memory based upon collective patterns and elements highly symbolic and aggregative. By analyzing this festivity it was possible to notice the popular culture great malleability and capacity of transform itself, and face new possibilities of interpreting both local history and the place of the popular culture in the Brazilian contemporary society.
\end{abstract}

Key words: feast of Holy Spirit, popular culture, collective memory and identity. 


\section{Capítulo I - O caminho teórico escolhido}

\section{1- Apresentação}

"É verdade que o mundo contemporâneo - neste momento da história denominado ora de sociedade pós-moderna, pós-industrial ou pós-mercantil, ora de modernidade tardia - está marcado pelos avanços na comunicação e na informática e por outras tantas transformações tecnológicas e científicas. Essas transformações intervêm nas várias esferas da vida social, provocando mudanças econômicas, sociais, políticas, culturais, afetando, também, as escolas e o exercício profissional da docência."

José Carlos Libâneo ${ }^{1}$

Sabemos o quão é intensa a discussão sobre o desafio da cultura popular na contemporaneidade. Achei interessante começar por essa citação de um pedagogo, José Carlos Libâneo, justamente por demonstrar que a discussão sobre qual o espaço restante da cultura popular neste dito mundo moderno é uma preocupação que transcende o campo de atuação de antropólogos, sociólogos e historiadores. Em um mundo propenso a valorizar a individualidade e uma espécie de uniformização de padrões culturais, vemos as manifestações folclóricas coletivas sendo cerceadas de forma cada vez mais forte e, muitos com certa razão em alguns de seus argumentos, já falam em fim da cultura popular.

Para mim estas tendências a ver negativamente o futuro da cultura popular constituem uma espécie de paradoxo. Morando em São Paulo, capital, para cursar História na Universidade de São Paulo, pude perceber bem a cidade brasileira que mais representa esta tendência à modernidade e à valorização da individualidade. Ao mesmo tempo, freqüentando todo fim-de-semana minha cidade de origem, São Luiz do Paraitinga, no vale do Paraíba paulista ${ }^{2}$, convivia com uma outra realidade que acabava e, aliás, ainda permanece, desdizendo muitas teses negativistas sobre um possível desaparecimento da cultura popular. Em São Luiz é possível ver, no mesmo século XXI, a força da cultura oral, a tradição dos grupos folclóricos, a identidade da comunidade perante valores coletivos além da manutenção de tradições seculares.

\footnotetext{
1 José Carlos LIBÂNEO. Profissão professor ou adeus professora? Exigências educacionais contemporâneas e novas atitudes docentes in "Adeus professor adeus professora”. Editora Cortez, São Paulo, 1998, p.23.

2 Vide mapa de localização do município luizense no anexo V no fim da dissertação.
} 
Neste quadro destaca-se a Festa do Divino Espírito Santo, que já dura, só em São Luiz do Paraitinga, mais de dois séculos.

Nesta festa, especificamente, podemos encontrar ainda hoje, vários "resíduos" de oralidade. O autor Eric Havelock aponta conceitos chaves em sua obra A revolução da escrita na Grécia para o entendimento deste objeto de análise:

"normalmente seguem a prática de reforçar os ritmos da métrica verbal casando-os com os ritmos de dança, dos instrumentos musicais e da melodia (...) uma canção é mais memorizável que um poema." 3.

Essas são características marcantes, por exemplo, nos grupos de folia do Divino que percorrem o município por quase um ano, exercendo forte influência sobre a população local. Como nas culturas orais, a interação dos cantadores com o público - a população de forma geral - é fundamental. No momento em que a folia está tocando, todos páram para vê-la, e a própria folia faz uso de recursos expressivos e dramáticos como pessoas vestidas de palhaço ou momentos do canto em que se expressa bastante sentimentalidade nas melodias e letras.

Exemplos como esse podem facilmente ser multiplicados nessa cidade, seja com os grupos de congada, de moçambique, de folia de reis, ou muitos outros que possibilitam apresentar a mesma questão: como é possível a sobrevivência destas manifestações na contemporaneidade, já que cada vez mais se dá destaque aos valores que são diversos dos pregados por estes grupos?

São fundamentais para grupos folclóricos como as folias do Divino valores como os de solidariedade, identidade de grupo, memória coletiva, oralidade, ao mesmo tempo em que não é difícil constatar como a sociedade contemporânea dá cada vez mais destaque aos valores de individualidade, de massificação de cultura entre outros similares, chocando-se diretamente com os citados anteriormente.

Nicolau Sevcenko é um dos historiadores que discute com clareza esta nova realidade em sua obra denominada A Corrida para o Século XXI ${ }^{4}$. Situa-nos em um

\footnotetext{
${ }^{3}$ Eric A. HAVELOCK. A Revolução da Escrita na Grécia, São Paulo: Unesp; Rio de Janeiro: Paz e Terra, 1996, cap.9, pp.187-218.

${ }^{4}$ Nicolau SEVCENKO. A corrida para o século XXI. No loop da montanha russa. São Paulo: Companhia das Letras, 2001.
} 
momento onde é cada vez mais difícil prever situações haja vista a velocidade das transformações tecnológicas ${ }^{5}$. Estas mesmas mudanças acabam abolindo tanto a percepção do tempo quanto as referências espaciais, abrindo-se, seguindo Sevcenko, o espaço profícuo ao termo globalização. E este novo mundo globalizado constitui um sistema que tem como característica fundamental fazer com que os indivíduos, nas mais variadas localidades, estejam conectados sob códigos semelhantes e uniformizadores. Fica assim, cada vez mais difícil, por exemplo, a renovação de um grupo folclórico, sendo tarefa quase impossível mostrar a sua importância às novas gerações frente às inovações que correspondem, sobretudo, aos valores de consumo e, praticamente, transformam em algo atrasado quaisquer manifestações tradicionais.

A sociedade contemporânea, entretanto, possui na contrapartida cultural, segundo Sevcenko ${ }^{6}$, a única forma de atuar criticamente sobre as inovações tecnológicas. Ao mesmo tempo em que estamos em um país alijado, de uma forma geral, dos principais desenvolvimentos do mundo globalizado, poderíamos transformar isto em um trunfo, apontando criticamente os limites da técnica através da contrapartida cultural. Mesmo estando próxima de grandes centros e com a população, na atualidade, interada com os meios mais modernos de comunicação existentes em nosso país - como a internet, tv a cabo -, é inegável o quanto ainda impera um modo de vida singular em localidades como a de São Luiz do Paraitinga, em uma posição totalmente diferente daquela pregada como moderna pelos grandes centros.

Mais interessante ainda é a força das tradições populares, opostas a estes princípios modernizantes, que conseguiram sustentar sua existência e seu papel fundamental para a identidade do povo no dia-a-dia desta realidade tecnológica. $\mathrm{O}$ mundo atual pode, sim, já ter provocado muitas mudanças no interior destas

\footnotetext{
${ }^{5} \mathrm{O}$ autor consegue sintetizar de maneira muito interessante as transformações de nossa sociedade em três períodos análogos ao passeio em uma montanha-russa. No primeiro momento quando no "brinquedo" se está subindo, Sevcenko compara com a realidade que engloba desde o século XVI até meados do XIX quando a elite européia se destacou ao dominar forças naturais, de comunicação e transporte e conseqüentemente expandir seu domínio pelo mundo. Em um segundo momento, ao descer no brinquedo de maneira extremamente rápida, estaria falando das inúmeras transformações que a sociedade recebeu em fins do século XIX, por exemplo, nas aplicações da eletricidade, dos derivados de petróleo, das indústrias químicas, entre outras. O terceiro momento, do "loop da montanha russa", seria esta nova situação que enfrentamos e que Sevcenko chama de "um novo surto dramático de transformações, a Revolução da Microeletrônica". Com as transformações cada vez mais velozes é de se imaginar a imensa dificuldade para os grupos folclóricos se adaptarem a este "novo mundo".

${ }^{6}$ Nicolau SEVCENKO op cit, p.16-22.
} 
manifestações, mas, a sua resistência e continuidade constituem um sinal importante de que estas possuem um espaço de destaque e um poder de transformação m chamado mundo moderno, globalizado e contemporâneo.

Entender essa espécie de paradoxo é algo que sempre me despertou imensa curiosidade surgindo como desafio para esta pesquisa, permitindo discutir a partir dele uma diversidade de questões correlatas. A partir de profícuas discussões nos cursos de História da Cultura, da África e do Cotidiano $^{7}$, cursados no bacharelado da Universidade de São Paulo, já pude começar a refletir sobre o papel da cultura na formação da identidade de um povo. É fundamental também para este entendimento a íntima relação das manifestações culturais com a história do cotidiano, sendo esta sempre entendida como um espaço de constante mudança.

\section{2 - Discussão sobre o conceito de popular:}

Definir cultura e cultura popular é um dos desafios fundamentais em qualquer projeto que trabalhe com temas como o da Festa do Divino. E inicio pela significação proposta pela pesquisadora Martha Abreu ${ }^{8}$. Segundo esta autora, o termo cultura popular, embora muito combatido por algumas correntes, consegue abarcar em seu interior um grupo constituído em sua maioria por pessoas das camadas mais baixas da população, mantenedoras de uma série de manifestações perpetuadoras de tradições como a de louvor ao Divino Espírito Santo - seu tema de investigação também.

Deixando clara a dificuldade de definição direta do que é cultura popular, Martha Abreu mostra um caminho onde o próprio grupo impõe pelas suas características singulares, sua diferenciação social:

“conceito que emerge na própria busca do como as pessoas comuns, as camadas pobres ou populares (ou pelo menos o que se considerou como tal) criavam e viviam seus valores e, no caso, as manifestações festivas, considerando sempre a relação complexa, dinâmica, criativa e política mantida

\footnotetext{
${ }^{7}$ Ministrados respectivamente pelo Prof.Dr. Nicolau Sevcenko, prof. ${ }^{\text {a }}$ Dr. ${ }^{\text {a }}$ Marina Mello e Souza e prof.Dr. Norberto Guarinello (org).

${ }^{8}$ Martha ABREU. O império do Divino: festas religiosas e cultura popular no Rio de Janeiro, 1830 1900. Rio de Janeiro: Nova Fronteira; São Paulo: Fapesp, 1999. pgs 27-29.
} 
com os diferentes segmentos da sociedade: seus próprios pares, representantes do poder, setores eruditos e reformadores". 9

Sabendo da amplitude de formas de interpretação da cultura popular, acabei adotando durante esta pesquisa uma linha muito próxima à proposta pelo prof. ${ }^{\text {d }}$ dr. ${ }^{\text {o }}$ Nicolau Sevcenko em curso ministrado na pós-graduação na Universidade de São Paulo, o qual acompanhei como aluno regular. ${ }^{10}$ Abriu-se um horizonte, verdadeiramente novo, quando foi ficando mais claro que uma festa popular característica como a do Divino Espírito Santo, em uma cidade singular como São Luiz do Paraitinga, não representaria apenas aquele embate direto de tradição versus modernidade.

Essa perspectiva permite a identificação do popular através de suas manifestações presentes nos momentos de destaque da festa, mas também, no dia-adia da comunidade. Os novos códigos que foram sendo criados, resignificados, permitem detectar a atuação do popular na história daquela comunidade. Existe uma espécie de "longa história" da cultura popular, pensando sempre nas conectividades existentes entre as relações internas desta população específica com as situações habituais da comunidade e com a sociedade brasileira de uma forma mais abrangente. Personagens, como o mestre da folia do Divino, constituirão uma classificação social diferenciada de seu grupo, transcendendo tanto o espaço e o tempo da festa.

Resumindo, a altura popular possui uma lógica diferenciada, possui um espaço de atuação próprio, um código de simbologias e concepções singulares e um tempo particular que precisam ser identificados conforme cada situação específica. É essa a missão deste trabalho visando a presença e atuação do "popular" na Festa do Divino luizense.

Dessa forma podemos concluir que a dita modernidade constitui sim um dos desafios maiores que este "mundo do popular" possa estar enfrentando, mas não

\footnotetext{
${ }^{9}$ Ibid, pg.28-29

10 SEVCENKO, Nicolau. "FLH-5115-1 - História da Cultura e Cultura Popular: Interveniências Temáticas, Analíticas e Conceituais". $2^{\circ}$ semestre de 2006. É necessário que fique claro que estou adotando um dos diversos caminhos apontados pelo prof. durante suas aulas expositivas e textos propostos. Foi fundamental perceber a diversidade da documentação adotada e analisada e sua amplitude de possibilidades, colocando-a em outra escala de tempo e de espaço, muito mais complexa do que aquela que estamos acostumados.
} 
podemos reduzir a questão a uma simples oposição. No capítulo V apresentarei duas novas manifestações privilegiadas neste caminho de buscar o sentido da cultura popular luizense e sua capacidade de transformação: o Carnaval $^{11}$ e a festa do "Raloim Caipira"12.

Exemplos fundamentais para ressaltar a capacidade de plasticidade das manifestações culturais, mostrou que ficar buscando permanências, resquícios ou mesmo continuidades - como é feito na maioria das vezes - transforma-se em um caminho "suicida" da própria dinâmica do popular. Isso seria limitar justamente o campo mais profícuo destas manifestações. A globalização não é simplesmente o outro lado da moeda que acabaria, no "fim da história", 13 com as manifestações tradicionais do mundo popular. Ela representa sim uma nova realidade, pois, são vários os exemplos de transformação de manifestações populares, transparecendo a sua plasticidade, e não uma situação estática, sendo isso o que é fundamental a ser ressaltado.

Cultura é algo vivo pulsante, e não possui centro, limite ou fronteira. Falo isso pois, sempre destacando o papel da cultura luizense especificamente, posso acabar passando uma imagem sobre a realidade de uma cultura estritamente local, quando a idéia de toda essa pesquisa é justamente a oposta. Neste espaço diferenciado de vivência do popular, encontramos os indícios de como não podemos

\footnotetext{
${ }^{11}$ O Carnaval de São Luiz do Paraitinga é semelhante à festa do Divino Espírito Santo no que diz respeito à constituição de um ambiente de efervescência cultural. Ganha uma nova identidade no início da década de 1980, sendo reconhecido atualmente como um dos mais tradicionais do estado de São Paulo. É totalmente baseado na participação popular, sendo sua principal característica diferenciadora ser formado por uma trilha sonora toda composta pela própria comunidade (reinterpretações das tradicionais marchinhas carnavalescas brasileiras). Dissertam em suas letras sobre a identidade local (personagens destacados na comunidade suplantaram o papel de figuras típicas do carnaval brasileiro como o arlequim e o pierrô). Há ainda fortes influências musicais de grupos como congadas, moçambiques e folias. Desta forma, será que quando percebemos uma diminuição no público em uma festa do Divino é o mesmo que sentenciar o fim do popular nesta localidade?!

12 A manifestação que surgiu recentemente na cidade, a festa do "Raloim Caipira" - segunda nova manifestação local que gostaria de ressaltar - reforça a questão dos pontos semelhantes destacados na nota anterior. Criada em 2001 - vide a página na internet www.sosaci.org.br - por um grupo que reúne intelectuais de diversas localidades, contadores de história da região de São Luiz do Paraitinga, músicos reconhecidos no cenário nacional e simpatizantes deste âmbito cultural de uma forma geral, congrega um grupo que vem transformando esta festa em algo de grande popularidade, ganhando importante espaço na imprensa brasileira, fundado no reconhecimento por pregar a valorização do folclore nacional. É feita a oposição da cultura popular brasileira frente à invasão estrangeira, por exemplo, ao se brincar com o conhecido "Halloween"norte-americano. A festa luizense, o "Raloim Caipira" acontece nas proximidades do dia 31 de outubro - data símbolo da festa norte-americana.

${ }^{13}$ Usando o sentido de "fim da história" proposto por Fukuyama em FUKUYAMA, Francis. Fim da historia e o último homem. Rio de Janeiro : Rocco, 1992. Lembrando que discordo do sentido finalista desta sua tese.
} 
simplesmente delimitar, classificar de uma forma rígida. Embora seja a festa do Divino de uma pequena cidade do interior o objeto de investigação, estamos analisando mecanismos sobre um modo de vida presente em diversas esferas e espaços da sociedade brasileira. Grupos afirmam suas concepções a partir de símbolos, representações coletivas, que formam a identidade coletiva. Ao mesmo tempo, é a partir da forma, das intenções com que nos dirigimos a um objeto específico, como a própria festa do Divino, que chegamos a um contexto cultural maior e seus múltiplos momentos, agora, pensando na constituição de uma identidade coletiva mais ampla. Ao nos aproximarmos da cultura popular, lidamos com valores ligados à autenticidade, à integridade. Tudo isso se opõe totalmente às questões homogeneizantes da modernidade. A realidade luizense expressa com clareza esse papel do popular na contemporaneidade.

Dessa forma, todas as manifestações culturais no mundo "moderno e globalizado" não podem mesmo ser simplesmente encaradas como "sobrevivências", contrapostas, agora, a uma nova realidade. É fundamental buscar entender cada "processo cultural", como define Néstor Canclini ${ }^{14}$, dentro de seu tempo e a partir de suas transformações. A festa do Divino de São Luiz do Paraitinga, mais do que resistência, interage e se transforma junto com as modificações de toda a sociedade, inclusive, fora do território luizense. Ao invés de buscar um discurso que mostre o contraponto, é importante ressaltar a necessidade de os discursos históricos ampliarem seu campo de ação, privilegiando estas diversas, porém, concomitantes realidades. Canclini define isso muito bem:

"Narrar histórias em tempos globalizados, mesmo que seja a própria, a do lugar que se nasceu ou se vive, é falar para os outros, não apenas contar o que existe mas também imaginá-los fora de si" ${ }^{\text {"15 }}$

Quando buscamos entender na atualidade o papel de uma folia do Divino para uma comunidade a ela identificada, crente, é incrível perceber o quanto é forte a relação da comunidade com o sagrado, tornando-a mais forte perante influências externas. Sem sombras de dúvida, é essa relação uma das características

\footnotetext{
${ }^{14}$ CANCLINI , Néstor García. Culturas híbridas. Estratégias para entrar e sair da modernidade. São Paulo: Edusp, $4^{\circ}$ edição, 2003.

${ }^{15}$ CANCLINI , Néstor García. A globalização imaginada. São Paulo: Editora Iluminuras LTDA, 2003. Página 48.
} 
fundamentais fortalecedoras da manutenção de manifestações populares em tempos e espaços dispersos na história, adaptadas às situações mais diversas a ela apresentadas. Entrevistando um dos mestres de folia de São Luiz do Paraitinga, seu José de Arimatéia, ficou claro a necessidade de um cuidado redobrado ao analisar uma cultura cujos padrões de funcionamento são muitas vezes diversos daqueles ao qual estamos acostumados, partindo de nossos próprios princípios.

Perguntei a ele como era possível a folia luizense - com mais de dois séculos de existência - não possuir ao menos um registro escrito dos cantos que realiza. Transcrevo agora sua resposta surpreendente para mim no momento. Entretanto, óbvia quando percebemos a dinâmica própria dessas manifestações no decorrer da história:

"Mas canto ao Divino não se escreve, a inspiração é do próprio Espírito Santo... É ele que nos ilumina e não nos faz esquecer, afinal somos representantes dele não é verdade...? São os momentos que nos apresentamos que mostram o que temos que cantar..."16

Assim, só se entende a Festa do Divino hoje, considerando suas concepções características em correspondências às manifestações da cultura popular no decorrer de nossa história. Seria limitar demais observá-la somente a partir das questões da atualidade, perdendo esta temporalidade mais ampla. Torna-se fundamental, dessa forma, ressaltar a importância do papel da oralidade e os caminhos de independência adquiridos por esta dentro das sociedades no decorrer da história. "O popular está sempre em tensão e fugindo do controle oficial do Estado, da Igreja, dos poderes públicos. "17

Representativa desta lógica que queremos afirmar para a cultura popular como um todo, a oralidade surge como outro grande exemplo. Ela nunca desapareceu. A invenção e a preponderância da linguagem escrita surgem como grandes desafios, contudo, nunca como interditos a esta manifestação. Neste mundo moderno, homogeneizante, encontramos, sim, muitas formas de manifestação da oralidade. E não são simplesmente as situações como as presentes no interior de

\footnotetext{
${ }^{16}$ Entrevista com José de Arimatéia realizada no dia 24 de junho de 2006.

${ }^{17}$ BENAMOU, Michel. Postface: Praise of Marginality in Alcheringa - A first international symposium. Cambridge: Boston, University Press, 1976, pg 133-142.
} 
festas tradicionais como as do Divino que gostaria de ressaltar nesse argumento, embora também o reforcem. Conversas via internet ${ }^{18}$, cada vez mais populares entre as pessoas em todo o mundo, vêm fortalecendo muito da atuação da oralidade na contemporaneidade, pois, afinal, estão constituindo praticamente um novo código de comunicação entre as pessoas. A escrita prevalece em programas como esse, porém, é totalmente modificada, com uma espécie de suspensão das regras que a formam. Além do mais, situações como risos, surpresas, símbolos constituem formas de representações comuns da oralidade, permitindo a comunicação de comunidades totalmente diferenciadas em uma espécie de criação de um "novo código".

O resultado desta análise preliminar foi a delimitação de um caminho para este desafio de definir o popular durante esta pesquisa, na qual a grande "descoberta", foi, justamente, o tamanho da complexidade desta questão. Dificuldades enfáticas da própria definição de quem seriam os "populares" sempre estão presentes nas discussões dentro da pesquisa. É tentadora, muitas vezes, a delimitação pura e simples de que os menos privilegiados na sociedade s̃o os membros da cultura popular. Porém, não é o único elemento a condição social para a classificação de quem faz parte de um grupo folclórico, ou seja, um participante ativo de uma festa popular. Da mesma forma, não se pode dizer o mesmo de um membro da dita "cultura de elite".

Outro entrave que deve ser superado é achar que os membros da cultura popular formam um grupo homogêneo. Uma das principais características, quaisquer que sejam as manifestações, é justamente a formação de um contexto de conflitos de interesses e atuações. Talvez, a cultura popular seja exatamente um grande nicho de diversidade, tornando ainda mais complexa a alocação de seus sujeitos como constituintes de um único grupo.

"A incerteza reconhecida acerca das fronteiras da área do popular, acerca da sua homogeneidade em face da unidade profunda e sempre reforçada da cultura das elites, poderia perfeitamente significar que a área do popular ainda não existe porque somos incapazes de falar dele sem fazer com que deixe de existir ${ }^{\prime 19}$

\footnotetext{
${ }^{18}$ Destaque para o programa Windows Live Messenger da multinacional Microsoft, propagado pelo mundo todo.

${ }^{19}$ REVEL, Jacques. A invenção da sociedade. Editora Bertrand Brasil S.A., Rio de Janeiro, 1989, página 64.
} 
Quando Edward Tylor (1832-1917) propôs, pela primeira vez, o termo cultura, respondia a discussões que estiveram presentes em toda a história da humanidade e visava sempre resolver o dilema entre "a conciliação da unidade biológica e a grande diversidade cultural da espécie humana" ${ }^{20}$. Neste momento, mostrava-se a cultura como uma espécie de aprendizado em detrimento da idéia de aquisição inata, tão presente em correntes historiográficas, em especial, a positivista. Os caminhos para a "independência" da cultura abriam-se cada vez mais e o homem passou a se sentir muito mais como resultado do meio em que se socializou e no qual responde a inúmeras influências hereditárias do que determinado por espaços geográficos e/ou biológicos.

Outra questão importante e já não tão recente na antropologia é a discussão que conseguiu romper a dicotomia entre cultura material e não material que persistiu por tanto tempo. A cultura material passou a ser encarada como portadora de conteúdos produzidos pela vida social dos indivíduos, onde qualquer homem intervém, influencia e é modelado. Como pano de fundo de quaisquer acontecimentos estão padrões e valores coletivos. Assim, todos os símbolos (artefatos) produzidos por uma cultura material devem levar em conta tanto o seu aspecto de produto como o de vetor de uma relação social.

Na Festa do Divino e na religiosidade popular como um todo, esta relação entre os símbolos, seus produtores e a sociedade constituem uma rede de relações envolvendo várias questões fundamentais à sua compreensão, exigindo - como se fosse totalmente possível - que fizéssemos "tabula rasa" de nossos conceitos e pudéssemos apreender rapidamente os padrões da cultura popular ao se aproximar dela. Entender símbolos como a bandeira do Divino, representa mais do que estudar a história dos grupos envolvidos com esse símbolo e sim, a busca do entendimento de um setor da sociedade brasileira que, na verdade, pautou sua religiosidade por padrões totalmente particulares, nos quais a relação direta estabelecida com o sagrado tem um papel fundamental no decorrer dos tempos. Nos capítulos

\footnotetext{
${ }^{20}$ Cliford GEERTZ apud Roque de Barros LARAIA. Cultura: um conceito antropológico. Rio de Janeiro: Jorge Zahar, 2004, pg 10-25.
} 
específicos sobre a festa perceber-se-á mais diretamente a força de toda esta simbologia.

Aliás, este mesmo exemplo pode servir como modelo para discutir outra questão importante: a definição de folclore e cultura popular. É comum ainda encontrar a separação elaborada sobretudo na década de 1980, entre os estudiosos da cultura popular - que englobaria as manifestações das camadas populares, a simbologia ali produzida e todo o processo histórico que se constituiu ao seu redordos folcloristas, muito mais preocupados em registrar as tradições e lutar contra o seu desaparecimento ${ }^{21}$. Seguindo a definição de Câmara Cascudo, o folclore é justamente a normatização da cultura do popular pela tradição. Algo assim constituinte e não diferenciador da cultura popular. ${ }^{22}$

O que precisa, entretanto, sempre estar claro, é que nunca tratamos folclore pensando-o como uma tradição estática. A manutenção de costumes é movida pela característica fundamental da cultura popular conforme apresentada anteriormente e influenciada por todo um contexto social, não sendo possível trabalhar com padrões estáticos de comportamento, como é comum quando nos referirmos à tradição desses grupos. É no dia-a-dia que as práticas culturais são transformadas e legitimadas, estando sempre suscetíveis às transformações dos novos padrões e desafios. Bom exemplo para o nosso caso é a já citada realidade da massificação da cultura na sociedade contemporânea valorizada pelos mais diversos meios e, nem por isso, determinante do fim da oralidade e do popular.

São Luiz do Paraitinga, desde sua elevação à Estância Turística, em $2002^{23}$, é caracterizada pela grande imprensa e mesmo por muitos artigos científicos como a cidade onde se mantém viva a "genuína" cultura caipira, incluindo a primazia da religiosidade popular, e constituindo um modo de vida não encontrado mais praticamente em local algum. Uma argumentação de certo modo romântica e até

\footnotetext{
${ }^{21}$ Marina de Mello e SOUZA. Patrimônio imaterial, turismo cultural e identidade nacional uma tentativa de refletir acerca de Parati. Revista Tempo Brasileiro, número 147 - outubro-dezembro 2001, pg 141.

${ }^{22}$ Luís da Câmara Cascudo. Đicionário do folclore brasileiro. $10^{\mathrm{a}}$ edição. São Paulo: Global, 2001, pg 240.

${ }^{23}$ Desde sua elevação à categoria de estância através do estatuto aprovado pela Lei Estadual de São Paulo $\mathrm{n}^{\circ} 11.197$, de 5 de julho de 2002 o turismo tem crescido de forma exponencial e a cidade vem recebendo um reconhecimento da sua vocação cultural haja vista a maior visitação e assim, a constituição do importante desafio de gerência desta realidade.
} 
exagerada, sendo ainda marcada, infelizmente, pela busca de uma realidade que estaria "congelada no tempo", esquecendo-se a fundamental característica de transformação presente no interior de toda cultura.

Um artigo interessante sobre esta questão especificamente é o "Carnaval caipira em São Luiz do Paraitinga. Chuva, suor, cerveja e chita" do professor da Faculdade de Arquitetura e Urbanismo Mackenzie, Abílio Guerra. Este autor faz críticas importantes à estrutura do turismo luizense, - que cresce de forma vertiginosa nos últimos anos - especificamente sobre o Carnaval. Entretanto, o enfoque é justamente o criticado logo acima:

"Esta cidade, que ao primeiro olhar despreocupado se assemelha a um vilarejo perdido no tempo, é habitada por uma comunidade pacata e hospitaleira (...)Surge diante dos olhos o inevitável: a total integração tecnológica ao mundo contemporâneo, a incompetência gerencial do município, o abismo entre a dimensão da festa e a capacidade da cidade em abrigá-la com um mínimo de conforto.(... ) Entretanto, o imponderável sempre pode surgir em cena. Todos os dias, no início da noite - horário quando ninguém estava dormindo ou dançando -, legiões de jovens sentavam-se em rodas nas calçadas, trocando impressões e experiências. De forma involuntária e absolutamente casual, acabaram por experimentar uma verdadeira tradição da vida caipira: tomar a fresca depois do jantar. Sem televisão, sem pressa, sem angústia." 24 .

É bem verdade que o próprio prof. Abílio Guerra insere em sua discussão uma crítica a "Nosso Feriado",25, revista local que tem sido distribuída aos turistas na cidade luizense, incentivando a busca deste cenário e do "caipira autêntico", utilizando-se inclusive de uma citação equivocada em sua colocação do dássico trabalho "Os Parceiros do Rio Bonito" ${ }^{\text {26 }}$ do prof. dr. Antonio Candido:

“O cidadão de São Luiz do Paraitinga representa perfeitamente o modo de vida caipira, com todos os aspectos daquilo que Antonio Candido definiu com tanta propriedade como Cultura Caipira. Segundo o ilustre ensaísta e crítico literário emérito 'a cultura caipira não é e nunca foi um reino separado, uma espécie de cultura primitiva independente, como a dos índios. Ela representa a adaptação do colonizador ao Brasil, portanto veio na maior parte

\footnotetext{
${ }^{24}$ GUERRA, Abílio. Carnaval caipira em São Luiz do Paraitinga. Chuva, suor, cerveja e chita. In Revista eletrônica Minha Cidade, número 178, fevereiro de 2007. http: // www.vitruvius.com.br/ minhacidade / mc178/ mc178.asp

${ }^{25}$ COSTA, Sérgio. A cultura caipira. Nosso feriado, no 5, São Luiz do Paraitinga, 2007, pág. 4. Foram mantidos os erros de grafia e de coordenação das citações presentes na publicação original.

${ }^{26}$ CANDIDO, Antonio. Os parceiros do Rio Bonito: estudo sobre o caipira paulista e a transformação dos seus meios de vida. São Paulo: Duas cidades, 2001.
} 
de fora, sendo sob diversos aspectos sobrevivência do modo de ser, pensar e agir do português antigo...' Os muitos anos de relativo isolamento fizeram que se conservasse muitos desses aspectos '... da difusão intensa da cultura portuguesa com a aborígine e conservando a fala, os usos, as técnicas, os cantos, as lendas...', continua o Antonio Candido, confirmando a gênese da criação do arquétipo do caipira '...que a cultura da cidade ia destruindo, alterando essencialmente ou caricaturando...' Nas palavras do ensaísta '... O caipira, um ser extraordinário, capaz de sentir e conhecer a fundo o mundo natural, usando o com uma sabedoria e eficácia que nenhum de nós possui' .,27

Um culto ao "caipira autêntico", ao isolamento, seria a própria estratégia de suicídio lembrando-se a realidade, cada vez mais clara, do contato com outras formas de manifestação pautadas na modernidade, na tecnologia, nos meios de comunicação de massa. Não há como pensar ser possível a manutenção de uma forma de vida isenta da adaptação à nova realidade da sociedade. Se já torna-se muito difícil a renovação de grupos folclóricos, como será possível atrair novas gerações se os padrões não condizem com a realidade por eles vivida?!

"De maneira que, hoje, quando estudamos a vida caipira, não podemos mais reportar-nos ao seu universo por assim dizer fechado, mas à sua posição no conjunto da vida do estado e do país."28

Ou seja, Antonio Candido mostra claramente a necessidade da busca do espaço do popular, do caipira, do oral na realidade atual e em consonância com o espaço ocupado pela modernidade, pela tecnologia, e não, simplesmente reduzindo a questão pelo caminho da oposição.

A Festa do Divino Espírito Santo de São Luiz do Paraitinga é emblemática na manutenção de tradições folclóricas que têm origens diversas, e que são extremamente marcadas pelas sociedades que a fizeram e transformaram-nas: desde a colonial portuguesa até a influência africana que a festa recebeu no Brasil. Na verdade, cada festa do Divino possui a sua própria feição, afinal, é essa a própria marca da cultura popular. Uma festa como a do Divino Espírito Santo é, sim, permeada por tradições comuns, contudo, sempre marcada por uma identidade própria.

\footnotetext{
${ }^{27}$ COSTA, Sérgio. A cultura caipira. Nosso feriado, $n^{\circ}$ 5, São Luiz do Paraitinga, 2007, pág. 4. Foram mantidos os erros de grafia e de coordenação das citações presentes na publicação original.

${ }^{28}$ CANDIDO, Antonio, op cit (2001), pg 271.
} 
Transformações que acabam definindo essas tradições folclóricas ou mesmo modificando-as ocorrem na esfera do cotidiano e são necessários também instrumentos específicos para entender as particularidades do cotidiano da cultura popular. A festa aparentemente é um momento corriqueiro dentro de uma sociedade, porém, é um momento de quebra de rotinas, regras e de exceção ampla dentro do cotidiano daquela comunidade. Não se pode esquecer, entretanto, que ela está sempre integrada a ele.

Isso porque o cotidiano precisa ser analisado sempre como protagonista dentro da análise histórica de uma sociedade. Ainda mais quando pesquisamos objetos como uma festa do Divino. Ele faz parte de um tempo, que segundo o historiador Norberto Guarinello, é o "tempo concreto da realização das relações sociais" ${ }^{29}$. Ou seja, o cotidiano é um palco privilegiado na constituição do folclore e da cultura popular. Pela ânsia de vislumbrarem-se grandes estruturas, perde-se a possibilidade de atentar para um campo que provoca profundas transformações no dia-a-dia das sociedades.

Um desafio constante às manifestações da cultura popular e bastante claro ao estudar esta festa luizense, é a ainda forte dicotomia existente entre a chamada "cultura de elite" e a manifestação do popular. Oposições como civilização X barbárie ou mesmo modernidade $X$ tradição são utilizadas de forma pejorativa na quase totalidade das discussões que tratam das manifestações folclóricas.

A autora Maria Laura Cavalcanti situa o movimento romântico - a partir de meados do século XVIII - como fundamental para a afirmação de noções como folclore e cultura popular. Surge assim um "mundo" idealizado, com uma vida integrada em sua totalidade e a valorização do primitivo ${ }^{30}$, do comunitário, do rural e do oral. Podemos ir mais longe a partir disso:

"Folclore/cultura popular e cultura de elite opõem-se nessa perspectiva. A questão pode tornar-se ainda mais complexa, se introduzirmos, nesse quadro, a idéia de cultura de massa com relação ao qual ambos os níveis de

\footnotetext{
${ }^{29}$ Norberto Luiz GUARINELLO. Festa, trabalho e cotidiano in JANCSÓ, Istvan; KANTOR, Íris (org) Festa: cultura e sociabilidade na América Portuguesa. São Paulo: Hucitec: Edusp: Imprensa Oficial: Fapesp, 2001, pg 966-975.

${ }_{30} \mathrm{O}$ termo primitivo que cito aqui precisa ser entendido como a forma da manifestação artística do popular, enraizada.
} 
cultura - popular ou de elite - exibiriam, ambos, uma aura de relativa pureza". 31

Peter Burke mostra que foi só por volta de 1800 que a cultura popular - como resultado de movimentos como as reformas católicas e protestantes, o movi mento renascentista, a criação de um código de conduta para os nobres suprirem sua diferenciação haja vista o declínio da vida militar - deixou de ser a cultura de todos: "uma segunda cultura para os instruídos e a única cultura para todos os outros"32. O novo código cultural para clero, nobreza e burguesia era pautado por uma forma diversa de falar e se portar com uma moral onde a ordem e o "autocontrole" eram básicos. Ficava, portanto, em direta oposição a todas as manifestações populares, e sua cultura passou a ser rejeitada por todos que se consideravam "elite".

Esta barreira conflituosa entre a cultura popular e a cultura de elite mantémse, na realidade, longe de ser equacionada. Esquece-se, comumente, que a cultura de um grupo social é algo constituído por todas as práticas sociais que formam este mesmo grupo e, onde o popular é muito mais ativo do que se costuma considerar. Burke indica novamente uma direção ao enfatizar que é extremamente vaga a fronteira entre as manifestações do popular e da cultura de elite. Assim, a melhor atitude é justamente a de procurar decifrar as características de suas interações do que classificá-las em patamares diferenciados.

O papel da oralidade - em quaisquer que sejam as sociedades humanas alimenta essa discussão, reafirmando a idéia de separação entre o oral como popular e o escrito como representante da elite. O texto "Origens douradouras",33 de George Steiner discute a complexidade deste conflito entre o oral e o escrito, citando Platão e sua visão da morte da memória a partir do desenvolvimento da escrita e mostra, do

\footnotetext{
${ }^{31}$ José Jorge CARVALHO apud Maria Laura Viveiros de Castro CAVALCANTI. Cultura e saber do povo: uma perspectiva antropológica. In Revista Tempo Brasileiro, número 147 - outubro-dezembro 2001, pg 70-71. Outra obra fundamental para essa questão, traçando um verdadeiro panorama do conceito do popular na história brasileira e da América Latina é a ORTIZ, Renato. Românticos e folcloristas. São Paulo, Editora Olho D'água. 1997.

${ }^{32}$ BURKE, Peter. Cultura Popular na Idade Moderna. São Paulo: Companhia das Letras, 1989, pg 291. Nesta mesma obra surge um exemplo de como identificar o popular, afinal quando Bakhtin (Mikhail BAKHTIN apud Peter Burke, op cit -1989- pg 21.) deixou de se opor às elites ao definir o Carnaval e o carnavalesco colocando-os em oposição a uma cultura oficial, processou-se uma mudança de paradigma. O popular poderia estar em qualquer pessoa (seria como a porção rebelde de cada indivíduo) e não restrito a um grupo social em determinada sociedade. Tudo isso sem falar na importância fundamental apresentada pelo trabalho de Bakhtin onde Rabelais torna-se um dos primeiros a escrever em língua vernácula e incorporar o repertório popular em sua obra.

${ }^{33}$ STEINER, George. Origens Douradoras. In Lições de Mestres. Editora Record, Rio de Janeiro, 2005, pg 19-54.
} 
outro lado, Jesus Cristo - o grande "mestre" Ocidental - provavelmente como analfabeto, ressaltando os limites deste papel determinado da escrita. É bem verdade que esta acaba refinando e reformulando muitos conceitos de identidade e de cultura de um grupo no decorrer do tempo, principalmente, pela oficialização, a partir da História, de muitas questões dos repertórios escritos em detrimento de determinados aspectos das manifestações sociais. Contudo, isso não é tudo.

Pensar o papel exercido pela oralidade nas festas luizenses é mostrar a tensão existente entre a oficialização propiciada pela escrita e a resistência demonstrada pela cultura popular, assentada mas manifestações orais. Essa importante lição fez com que eu deixasse de considerar, nessa pesquisa, a oralidade e os valores coletivos a ela associados "apenas" como um contraponto aos padrões individualizados pregados no mundo moderno.

\section{3 - A questão fundamental da memória}

Outro exemplo claro da importância da cultura popular é sua função para a construção da memória de um povo. Os acontecimentos históricos nunca farão sentido por si mesmos, afinal, só incorporamos conceitos na nossa experiência sensitiva se isto vier acompanhado de significados e símbolos de identificação para nós. A memória representa a reprodução de um passado que guardamos, porém, sempre resguardado de uma forma especial. Simbologias como as presentes na festa do Divino são fundamentais para perpetuar significados coletivos entre os que a vivem e dela participam.

Esta festa será um palco emblemático para comprovar o argumento de Halbwachs ${ }^{34}$ quando diz que a memória individual, embora exista e possua suas especificidades, só comprova-se a partir do grupo em que foi constituída e necessita ser confirmada a todo instante pela sociedade. Halbwachs rompe a idéia de um tempo privilegiado e estável onde se desdobrariam todos os fenômenos humanos. Há sempre de se considerar um tempo coletivo em consonância ao individual e movido pelos questionamentos do momento vivido por todas as pessoas.

\footnotetext{
${ }^{34}$ Maurice HALBWACHS. A memória coletiva. São Paulo: Centauro, 2004.
} 
Dessa forma chega-se a uma consciência de que jamais estará fechada sobre si mesma. A memória constituída no interior dos grupos folclóricos, ou da festa do Divino como um todo, não é algo semelhante no decorrer da história, pois está sujeita a "invenções" típicas da construção da memória coletiva.

Jean Duvignaud, comentando o texto de Halbwachs, constata, a partir dessa discussão, a distinção entre a "memória histórica" formada pelos fatos do passado construído a partir do presente, e a "memória coletiva" que traz um aspecto mais mágico a este mesmo passado. ${ }^{35}$ A festa permite a construção dessa memória coletiva e também acaba influenciando diretamente a história do local no qual se realiza.

Halbwachs mostra ainda que tanto uma guerra como uma cerimônia, ou mesmo uma festa popular, são fatos únicos em seu gênero, pelos quais a existência de um grupo é sempre modificada. Entretanto, para isso acontecer, é necessário que uma série de imagens que atravessam as consciências individuais se coloquem sob o ponto de vista do grupo para, aí sim, se consolidarem e se constituírem em eventos ordinários na história dos próprios grupos onde acontecem. Assim, esta nova situação deixa de ser apenas impressão pessoal e passa a se apoiar na memória histórica - uma nova construção do passado a partir da nova realidade presente. ${ }^{36}$

A memória, é importante atentar, constitui algo sempre altamente seletivo, funcionando com um mecanismo de esquecimentos programados, onde os fatos que ganham mais destaque são justamente aqueles em que a comunidade como um todo se destaca. Os eventos da festa do Divino Espírito Santo são todos extremamente marcantes para os habitantes de São Luiz do Paraitinga, fazendo parte, inegavelmente, da memória coletiva local. Estudar o que se mantém e o que se modifica nesta festa, é, acima de tudo, estudar a constante transformação da história dessa comunidade de uma forma geral.

David Lowenthal discute igualmente estas especificidades da memória e sua relação com a história atentando para a importância de determinadas pessoas para a sua constituição. Apesar de se basear sempre em um sentimento coletivo, como discutido acima, é importante relativizar e mostrar a memória como algo também

\footnotetext{
${ }^{35}$ Jean DUVIGNAUD. Prefácio. In Maurice HALBWACHS op cit (2004) pg10-11.

${ }^{36}$ Maurice HALBWACHS. A memória coletiva. São Paulo: Centauro, 2004, pg 65.
} 
individual e parcial, onde determinadas pessoas têm mais autonomia que outras, selecionando fatos de acordo com suas vontades ${ }^{37}$.

Assim, a memória torna-se um sistema autônomo que mais articula a realidade do que a reflete. O que não faz, como apontei logo acima, da memória algo absolutamente individual, ela possui, sim, um limite importante justamente por partir do individual, porém, é extremamente necessário uma espécie de legitimação coletiva para confirmar e ligar suas lembranças com os fatos históricos. Muitas vezes, a participação pessoal do indivíduo nos acontecimentos importantes da história é exagerada pela sua ânsia de participar ativamente na sua constituição. Isso é bastante claro em alguns depoimentos sobre a festa do Divino na qual ter um papel de destaque em sua organização indica um lugar social importante. Em entrevista com Dona Benedita Antunes de Andrade ${ }^{38}$ ela cita um verso de sua autoria que, longe de quaisquer análises teóricas, traz à tona essa mesma discussão:
"Para que a memória não se perca
$\mathrm{O}$ que se tem registrado
Não será esquecido
Um dia será lembrado
E à memória devolvido"39

É bem provável que ela pense apenas na primazia da necessidade do registro escrito como possibilidade de manutenção da memória. Entretanto, a questão do retorno à memória mostra claramente a adaptação ao presente dos fatos do passado. Além do que, a partir da memória também se consegue, e de maneira muito importante, o fortalecimento da legitimação do indivíduo a partir da sua identidade local. É o caso desses versos de Dona Benedita Antunes. Citando o próprio Lowenthal, a partir do fortalecimento da memória coletiva no decorrer da história constitui-se uma identidade de uma coletividade como um grupo social, ou mesmo, um país: "Relembrar o passado é crucial para nosso sentido de identidade: saber o que fomos confirma o que somos".40

\footnotetext{
37 LOWENTHAL, David. Como conhecemos o passado. In Revista do Programa de Estudos Pós Graduados em História do Departamento de História Da Pontifícia Universidade Católica de São Paulo: Projeto História - trabalhos de memória. São Paulo, número 17, novembro de 1998.

38 Em setembro de 2007. No capítulo III apresentarei o histórico dessa senhora tão importante na organização das Festas do Divino da cidade.

39 Entrevista realizada no dia 25 de maio de 2007.

${ }^{40}$ LOWENTHAL, David, op cit, página 83.
} 
É a memória que estabelecerá um ponto de partida para se buscar uma visão do passado, entretanto reafirmando sempre a situação do presente. Essa é uma visão também muito diferente do rigor científico que um discurso histórico, nos padrões ditos "tradicionais", busca construir. O autor José Carlos Sebe demonstra esta especificidade da memória na seguinte afirmação:

"Memórias são lembranças organizadas segundo uma lógica subjetiva que seleciona e articula elementos que nem sempre correspondem aos fatos concretos, objetivos e materiais ${ }^{\wedge 11}$.

Entender um pouco a metodologia de trabalho da História Oral ${ }^{42}-$ extremamente importante durante a pesquisa - foi fundamental no contato com os realizadores das comemorações ao Divino. Aliás, nunca imaginaria a possibilidade de manter em um trabalho acadêmico - como esta dissertação - exageros como um exemplo presente no relato de Dona Cinira ${ }^{43}$ quando parecia que estivera presente no momento da visita de Dom Pedro II à cidade de São Luiz do Paraitinga, em meados do século XIX. Permitir a manutenção de informações como essa - como faço no capítulo seguinte, tratando da história do município luizense - permite a possibilidade de revelações importantíssimas que acabam surgindo em momentos simplesmente ignorados por uma perspectiva "convencional" onde se omitem estes fatos considerados "mentirosos".

Foi só a partir deste "exagero" da colaboradora que se pode discutir uma concepção fundamental na identidade luizense durante sua história: a construção de um mito do "baronato". Essa construção - que retomarei no capítulo seguinte - está ainda presente nas festas do Divino e é partilhada pela comunidade como um todo.

\footnotetext{
${ }^{41}$ José Carlos Sebe Bom MEHYI. Manual de História Oral. Edições Loyola, São Paulo, Brasil, $4^{\mathrm{a}}$ edição, maio de 2002. pg 54-55.

${ }^{42}$ Recolhido o material das entrevistas, passei pelos processos recomendados pelo prof. Bom Meihy - op cit. - em seu manual, sendo sua concepção de história oral a adotada nesta pesquisa. Primeiramente o processo de transcrição, tentando não perder signos importantes a partir de recursos de pontuação, da manutenção de interjeições e expressões reveladoras do repertório do colaborador, sendo muito mais que uma "simples" transmissão absoluta de um texto oral para o escrito. Feita a transcrição de todas entrevistas, suprimi as questões que eu fizera ao colaborador. Consegue-se imprimir um caráter textual e narrativo ao material recolhido. Assim, por fim, seguindo uma seqüência cronológica, mas, não sendo pautado por uma rigidez absoluta, trabalhei com o processo de transcriação com a totalidade do material recolhido. Neste processo que nega totalmente a possibilidade de neutralidade de quem faz a pesquisa, não se busca o utópico "fato legítimo" e, sim, a experiência.

${ }^{43}$ Resultado de uma série de entrevistas com Dona Cinira dos Santos em setembro de 2006. Viúva do compositor Elpídio dos Santos, ela representa uma espécie de ícone da história local, sendo respeitada por toda a população como "guardiã" da memória luizense.
} 
A partir de um relato individual, como nesse exemplo, podem surgir os caminhos que marcam a identidade de toda a coletividade.

Retomo mais uma vez Néstor Canclini para mostrar como a memória pode ser o meio com o qual estes sujeitos conseguem reafirmar, através dessa festa e de outras manifestações da mesma natureza, o papel que eles próprios ocupam m mundo moderno:

“A comemoração se torna uma prática compensatória: se não podemos competir com as tecnologias avançadas, celebremos nosso artesanato e técnicas antigas; se os paradigmas ideológicos modernos parecem inúteis para dar conta do presente e não surgem novos, re-consagremos os dogmas religiosos ou os cultos esotéricos que fundamentaram a vida antes da modernidade ${ }^{, 44}$.

\section{4 - A festa do Divino Espírito Santo de São Luiz do Paraitinga como representação de uma cul tura diferenciada.}

Meu objetivo inicial nessa pesquisa era encontrar explicações parar a persistência da Festa do Divino em São Luiz do Paraitinga no ambiente "hostil" da modernidade, buscando respostas que explicariam o fenômeno a partir do isolamento, em uma simples oposição entre modernidade e tradição. A grata surpresa foi justamente descobrir - e graças à aproximação deste modo de vida e totalmente diferenciado formulado pelos "populares" - o quanto estaria reduzindo a análise com esta simples oposição.

Entendi as manifestações em louvor ao Divino - e que já duram mais de dois séculos nesta pequena cidade, atravessando todo o apogeu econômico do município no tempo do café - como a possibilidade única de reforçar a construção da memória e do passado luizense. A resposta para a inquietação inicial seria, dessa forma, demonstrar a força mantenedora de tradições como a dos grupos folclóricos - já desaparecidas na maior parte do país - como uma possibilidade de se enfrentar o "perigo modernizador" e não perder a identidade de uma época de destaque da história da região.

\footnotetext{
${ }^{44}$ CANCLINI , Néstor García. Culturas híbridas. Estratégias para entrar e sair da modernidade. São Paulo: Edusp, $4^{\circ}$ edição, 2003.pág.: 166.
} 
Foi ficando claro, entretanto, que a força da tradição era uma das motivações primordiais, contudo, insuficiente. A pesquisa acabou demonstrando a necessidade da discussão de um sentido mais amplo para esta questão: a colocação da cultura popular luizense em um campo de atuação alongado no espaço e no tempo, e não simplesmente, em estratégia de sobrevivência na modernidade, graças ao seu isolamento. Só mostrar a importância das tradições soa como um discurso condizente com as teses baseadas em uma visão até romântica da manutenção do folclore como algo estático. O dinamismo e a plasticidade são as marcas desta cultura. Além do que, São Luiz do Paraitinga está localizada a apenas cinqüenta quilômetros da via Dutra, interligada aos mesmos meios de comunicação acusados pela disseminação dos padrões massificadores por todos os cantos do planeta. Seria a mesma coisa que continuar defendendo a sobrevivência de algo com data marcada para desaparecer.

Não estou questionando com isso toda a construção - muito importante por sinal - existente sobre a cidade de São Luiz do Paraitinga e colocando-a como "guardiã do popular", mesmo que transparecendo uma concepção da manutenção da cultura em padrões estáticos. E essa construção, por sinal, está fortemente ligada à realização da festa do Divino, consolidando alguns consensos tanto para seus habitantes como para aqueles que se dirigem a eles através da imprensa ou mesmo por meio do turismo. E é, sim, importante, no momento, se empenhar na manutenção de representações. O próprio movimento que se constrói para apoiar um grupo folclórico em desaparecimento - mesmo que pregue um caminho de revivê-lo em padrões ultrapassados - é muito importante para estabelecer uma base fundamental à sua sobrevivência, demonstrando a valorização de sua atuação na atualidade.

Vejamos, agora, alguns dos dogmas presentes na concepção dos luizenses ligados às festividades do Divino e, mesmo revelando concepções muitas vezes diversas das situações encontradas nos documentos, fundamentais à sua manutenção: um ideal da rememoração de um tempo de destaque de sua urbe na província de São Paulo - sendo São Luiz a primeira cidade planejada desta-; ou a marca na história exercida por uma localidade classificada como um importante entreposto comercial no caminho ao litoral - recebendo a construção de inúmeras 
edificações históricas, hoje, tombadas ${ }^{45}$; o orgulho propagado pela manutenção de dezenas de grupos folclóricos, lembrando o status cada vez maior da cidade na grande imprensa por essa identidade ímpar; a cidade guardiã do título de "cidade imperial" atribuído por D. Pedro $\mathrm{II}^{46}$. Na verdade poderia continuar citando muitos outros exemplos, porém, o mais importante é a constituição de uma concepção da história local "exagerada" em seus feitos ligados ao mundo da cultura popular, fundamental para a identidade do luizense nesta "nova" sociedade, moderna.

Remeter-me-ei no capítulo seguinte a vários documentos apontando esse rico passado luizense, tão reafirmado por sua população, entretanto, muito mais fruto daquela memória coletiva construída e seletiva do que amparado na realidade dos fatos. Situação que não diminui em nenhum grau a importância desta construção popular para a "história oficial", afinal, só confirma que a cultura popular é um tema com uma dinâmica diferenciada e que necessita de muito cuidado em sua análise. Verdade absoluta dos fatos é algo inatingível e construções que passam a ser reconhecidas pela maioria transformam-se no melhor caminho para a identificação da própria comunidade como viventes de uma história comum e, no caso, de destaque.

O município luizense era comandado, sobretudo no século XIX, por um pequeno grupo de grandes fazendeiros - responsáveis pela construção do conjunto arquitetônico ainda hoje existente - sendo, na verdade, a pobreza a principal marca da sociedade. A produção cafeeira luizense também sempre esteve longe dos principais produtores da época, inclusive, no próprio vale do Paraíba. Porém, é exatamente essa "invenção da tradição"47 que normatiza e fortalece o sentido da identidade do luizense atual, respondendo pela sua atuação frente aos grupos folclóricos e manifestações religiosas e por diversas outras formas de manifestações populares.

Qualquer festa é um momento importante para a sociabilidade, mas, a do Divino, por ser a mais tradicional em São Luiz do Paraitinga, mostra isso com força

\footnotetext{
${ }^{45}$ São Luiz do Paraitinga possui o maior conjunto arquitetônico tombado pelo CONDEPHAAT segundo os registros do próprio órgão.

${ }^{46}$ São Luiz do Paraitinga obteve no dia 11 de junho de 1873 o título de "Cidade Imperial" atribuído por Dom Pedro II momentos antes da passagem de sua corte pela cidade. Vide Comitê Pró Associação para o Desenvolvimento Cultural e Ambiental de São Luiz do Paraitinga (org). São Luiz o ano inteiro. Taubaté: Vogal Editora, 1997. página 18.

${ }^{47}$ HOBSBAWM, E. J. Sobre história : ensaios. São Paulo : Companhia das Letras, 2007.
} 
ainda maior. É esclarecedor quando Marina de Mello e Souza diz: “As festas geralmente congregam diferentes segmentos sociais, sendo momento privilegiado para o exercício de trocas culturais" ${ }^{48}$.

O festeiro do Divino é um ser influente e que ao realizar a festa reafirma sua posição e sua identidade. Na organização das festas, se encontram grupos disputando hierarquias, lugares sociais. A festa, ao mesmo tempo em que unifica, acaba também diferenciando tanto os que participam ativamente dela como os que estão fora. Analisar a Festa do Divino de São Luiz do Paraitinga no fim do século XIX, por exemplo, é analisar a força dos principais grupos cafeeiros que geralmente eram os festeiros do Divino e determinavam o espaço bem delimitado da população dentro de suas manifestações.

A festa do Divino luizense possui ainda uma especificidade fundamental na discussão da congregação social. O rei e a rainha do Congo - membros representativos das irmandades dos "homens pretos", notoriamente um segmento oprimido na história de nosso país - são figuras de destaque na procissão do Divino, no dia principal da festa. Não se pode esquecer, que esta festa está agora ligada às irmandades brancas, sempre reafirmadoras de padrões da elite, sobretudo, os ligados à realeza, mesmo contando predominantemente com a ação da população mais simples. ${ }^{49}$ Documentos da paróquia local mostram de forma até surpreendente alguns casos de escravos sendo aceitos em irmandades elitistas como a do Sagrado Coração de Jesus, não se esquecendo de estarmos situados no auge da opressão da mão-de-obra cafeeira. ${ }^{50}$ Podemos, a partir disso, pensar em caminhos novos de entendimento onde ascendem figuras como a de Salvador Barbosa ${ }^{51}$ - rei Congo por

\footnotetext{
48 Marina de Mello e SOUZA. Parati: a cidade e as festas. Rio de Janeiro: Editora UFRJ/ Tempo Brasileiro, 1994.

49 A autora Marina de Mello e Souza nos lembra como desde a época colonial as irmandades foram adquirindo um caráter segmentar racial e social, separando as pessoas por classes sociais, e inclusive, considerando a cor da pele como fator determinante. Vide SOUZA, Marina de Mello e. Reis Negros no Brasil Escravista: história da festa e coroação do Rei Congo. Belo Horizonte: Editora UFMG, 2002.

${ }^{50}$ Os documentos citados são livros-tombo da filiação das irmandades que datam desde o fim do século XVIII pertencentes à Paróquia São Luiz de Tolosa, esta, membro da diocese de Taubaté/SP. Um exemplo muito interessante destes casos citados é o de um escravo, sr. José do Patrocínio, propriedade de um padre - sr. Pedro Antonio - que tem sua anuidade paga e a aceitação na irmandade datada do ano de 1867.

${ }^{51}$ Retomarei o papel deste personagem no capítulo sobre a história da festa do Divino em São Luiz do Parait inga por vários motivos: o papel de preponderância que assumiu nas festas recentes - até sua morte, em 2003, era uma das principais personagens no interior da festa -; construiu uma identidade muito forte, sendo um "sinônimo" da cultura popular para os próprios luizenses; e foi o personagem principal de outro acontecimento interessantíssimo na festa luizense: uma coroação oficial como o "Rei do Congo" no ano de 1981, em uma festa do Divino montada em setembro - foi a segunda daquele ano! - e que contou com
} 
mais de trinta anos nas festas luizenses -, ou muitos líderes de congadas e moçambiques que tiveram seu espaço de preponderância na sociedade luizense no decorrer de sua história.

Assim, toda festa, embora possua um calendário anual com as mesmas manifestações - peregrinação da folia, encontro de bandeiras, novena, distribuição de comida... -, diferencia-se a cada ano, estabelecendo novas relações sociais em campos diversos. "A festa é, assim, não um simples somatório, mas uma articulação de festas singulares". 52

Semelhante ao cotidiano - e como já ressaltado também constituinte deste - a festa, em reproduções aparentemente estáticas, possui uma incrível dinâmica onde todo o grupo social participante age sobre si mesmo, modificando a realidade de toda a comunidade. As transformações dentro das manifestações costumam ser muito maiores do que nos damos conta e não só refletem as transformações exteriores ao grupo social como uma nova atitude destes frente à sociedade. Martha Abreu mostrou como a festa do Divino era sempre um momento propício para negociações culturais, conversas e comunicações de uma forma mais ampla na sociedade carioca no período de 1830-1900, sendo, muito mais que entretenimento, decisiva para os rumos da sociedade carioca daquele momento. ${ }^{53}$

A festa do Divino em São Luiz do Paraitinga discute, hoje, em seu interior como em toda sua história - questões políticas das mais diversas e disputas por influência mo interior da comunidade a partir do destaque que ela proporciona. A mesma lógica pregada por Martha Abreu em uma situação espacial e temporal diversa.

O status das pessoas da sociedade é muitas vezes questionado por eventos da festa e, justamente, uma das características mais importantes e conflituosas na manutenção da festa do Divino - causando inclusive discussões muito mais amplas na Igreja Católica - é a forma como a religião é praticada pelos fiéis nas comemorações em louvor ao Espírito Santo. A Igreja Católica nunca conseguiu

\footnotetext{
representantes de destaque da política - governador, secretário da cultura - e do clero local - incluindo-se de maneira ainda mais surpreendente um membro do Vaticano.

52 GUARINELLO, Norberto. Festa, trabalho e cotidiano in JANCSÓ, Istvan; KANTOR, Íris (org) Festa: cultura e sociabilidade na América Portuguesa. São Paulo: Hucitec: Edusp: Imprensa Oficial: Fapesp, 2001. Pg 974.

53 Martha ABREU. O império do Divino: festas religiosas e cultura popular no Rio de Janeiro, 18301900. Rio de Janeiro: Nova Fronteira; São Paulo: Fapesp, 1999. pg 14.
} 
brecar a relação direta que ocorre entre os indivíduos participantes das festividades com a esfera do sagrado. Por mais que esta instituição venha tentando modificar manifestações para justamente ter mais controle sobre os eventos, é muito difícil modificar práticas populares. Novamente, na atualidade, está evidente a força da cultura popular e como ela é resistente no decorrer da história.

É sempre importante pensar ms situações de manutenção e concomitante mudança no interior das festas populares. Um dos primeiros motivos que me despertou o interesse em estudar a Festa de São Luiz do Paraitinga, já nos tempos do início da graduação ${ }^{54}$, foi a diferença entre suas manifestações atuais e a de alguns anos anteriores, ainda em minha infância. Por mais que seja representativa a afirmação da importância e da pujança atual da Festa do Divino luizense, é inegável que muitos grupos folclóricos vêm perdendo sua força e, com relação à própria festa, cabe a interrogação do quanto ela é forte o bastante para enfrentar os "impactos da modernidade".

A constatação mais evidente para a maioria da população luizense é, sim, a triste impressão da sua decadência. O grupo tão tradicional de jongo, por exemplo, de cinco anos para cá não se apresenta mais ${ }^{55}$. Quanto aos grupos de folia que se revezavam durante as festividades, atualmente, são "emprestados" músicos de municípios vizinhos para a coleta de prendas para a festa.

Na realidade, o que não costuma ser tão perceptível, é que as próprias pessoas não vêm perdendo toda a sua devoção e seu empenho na realização da Festa do Divino como parece à primeira vista e se costuma profetizar. É fato a decadência de certos grupos, mas também é verdade que novos grupos e novas formas de manifestação acabam surgindo desde que se consiga transmitir o sentido destes grupos para as pessoas, principalmente, os mais jovens. Ou mesmo, que as pessoas têm buscado outros caminhos mais próximos da sua realidade atual, para os mesmos fins de tempos atrás.

\footnotetext{
${ }^{54} \mathrm{O}$ primeiro trabalho sobre o tema foi um seminário a respeito da relação dos cantos da folia do Divino com a cultura oral apresentado no curso "História da Cultura", ministrado pelo prof. Dr. Nicolau Sevcenko, no segundo semestre de 2000.

${ }^{55}$ Em 2008 houve uma tentativa de revitalização da apresentação dos “jongueiros” luizenses coordenado pelo professor da Unicamp Alberto T. Ikeda - pesquisador de longa data das manifestações populares da cidade -, entretanto, não se conseguiu constituí-la como de costume. Acabou sendo uma conversa muito rica entre este pesquisador e os antigos integrantes das tradicionais rodas de jongo da cidade.
} 
Ainda se crê em São Luiz do Paraitinga, principalmente, nas regiões da zona rural, na importância da doação da prenda do Divino para colher bons frutos em sua plantação, como manda a tradição da ligação direta entre o homem e o sagrado expressada nessa festa desde suas origens anteriores ao catolicismo. Embora seja cada vez menos comum as pessoas levarem suas bandeiras nas procissões, não se pode afirmar que o Divino deixou de ser fundamental em suas vidas. É claro, sobretudo com o avanço do turismo, que há um risco constante da transformação de manifestações tão carregadas de sentidos próprios e historicidade em formas mais próximas da cultura de entretenimento. Porém, não se pode nunca esquecer que ao encararmos a manutenção de uma tradição popular como algo estático, estaremos justamente tirando o cerne da cultura popular: a sua dinâmica de mutabilidade.

Além disso, mesmo quando ocorrem transformações consideradas extremamente negativas pela população como o desaparecimento de certas apresentações tradicionais, antes de considerá-la decadente é necessário refletir um pouco mais. Por exemplo, um mesmo grupo de congada que se preza por estar desfilando há mais de 200 anos nas festas de São Luiz do Paraitinga, exemplo vivo da transmissão de seus valores pelas gerações, manteve-se apresentando da mesma forma ou modificou vários sentidos em suas apresentações no decorrer do tempo? Além disso, será que a população receptiva às suas apresentações na atualidade não os enxerga de forma totalmente diferente daqueles que os acompanhavam no contexto da escravidão em meados do século XIX? Antes de detectar seu enfraquecimento é preciso investigar se novos elementos não são tão importantes como aqueles que se perderam.

São Luiz do Paraitinga sempre foi exaltada pelo seu isolamento que acabou permitindo, ou ao menos contribuindo, para a formação de uma identidade comum. Essa nova situação na qual se reafirma o contato cada vez maior com outros públicos, surpreendentemente, tem produzido novas saídas como a do Carnaval e da festa em afirmação do folclore brasileiro: eventos também representativos do cidadão brasileiro, do popular, frente à cultura massificadora da modernidade globalizadora. Dá até para pensar: será essa globalização tão “demonizada" mesmo assim em seu confronto com o popular? Afinal, é ela mesma que permite - ou até obriga - o fortalecimento da cultura popular pela busca de novos caminhos pelos 
seus indivíduos, não a fadando ao desaparecimento pela possível estagnação em suas manifestações.

Assim, ao afirmar a cultura popular como algo definidor e preponderante na memória e na identidade da sociedade luizense, se reforça este perfil de mudança muito mais do que a imagem isolacionista deste grupo. Observar seus momentos de transformações, recriações e, mesmo, abandono de tradições é fundamental para um melhor entendimento de suas manifestações. Considerar, assim, uma festa decadente por ela apresentar aspectos que são diversos da sua constituição em décadas atrás ou mesmo diferentes dos novos padrões culturais - como ainda vem sendo feito por muitas pessoas - acaba caracterizando um caminho simplista e até desrespeitoso com os que ainda a mantêm, trazendo sentido para sua realização seja isto consciente ou não. Deixar de contemplar novas formas de manifestação, mesmo muito diferentes daquelas praticadas em louvor ao Divino, parece não levar em consideração, da maneira apropriada, esse "mundo" tão rico e complexo. É essa a missão que me proponho a partir de agora nessa pesquisa.

\section{5 - As indagações que nortearam a seleção das fontes e a periodização:}

A primeira motivação para o presente projeto foi derivada da própria curiosidade e vontade em conhecer, analisar e interpretar mais a fundo aspectos da cultura popular da região à qual pertenço e tanto me identifico. Desde a infância pude acompanhar manifestações culturais, na sua maioria religiosas, com variados registros de devoção e tradição. Procurar conhecer melhor como isto se constituiu e se alterou no decorrer do tempo tornou-se tarefa extremamente convidativa. Embora muitas manifestações já tenham sido analisadas por alguns cientistas sociais e historiadores é certa a existência de um amplo campo de pesquisa sobre uma cultura tão especial e cujos resultados podem ajudar a pensar o crescimento do interesse por São Luiz do Paraitinga e, consequentemente, sua cultura.

Procurar entender as alternativas que os próprios grupos folclóricos têm criado para a sua sobrevivência na atualidade, ou mesmo a incapacidade de alguns em se manterem, é uma das discussões ainda a serem feitas sobre a realidade 
luizense. Escutar diretamente as pessoas, membros destes grupos, tem constituído um aprendizado inestimável.

Foi sendo criada pela própria pesquisa uma necessidade cada vez maior por saber um pouco mais da história local de São Luiz do Paraitinga. Mesmo endo como foco principal a festa na atualidade, o trabalho optou por comparar a festa atual com seu momento de maior destaque - início do século XX - coincidente com o ciclo cafeeiro, o que exigiu buscar substratos na história do município para inserir a festa e sua concepção social naquele momento.

E tendo que fazer essa busca da história local como substrato ao entendimento da festa do Divino, a periodização adotada por esse projeto acabou adotando o "tempo longo" chegando até a atualidade. Uma temporalidade ampla, mas, com um recorte direcionado aos acontecimentos ligados às festividades em comemoração ao Divino Espírito Santo. Permitindo dessa maneira uma perspectiva comparativa entre uma festa do XIX, do século XX e outra já do XXI.

A construção desta tarefa, entretanto, foi se mostrando bastante difícil devido à existência de pouquíssimos trabalhos já escritos sobre a história luizense e que pudessem servir de suporte comparativo. Sempre referência atual em artigos que tratam do Divino, do Carnaval, do turismo cultural, ecológico, os trabalhos sobre a história da cidade de São Luiz do Paraitinga são ainda bastante escassos.

E embora não tendo como propósito escrever uma história desta cidade, fui tomando contato, por exemplo, com os documentos existentes nos arquivos públicos que se remetem ao início da constituição desta cidade, e acabei instigado a dedicar um capítulo inteiro sobre este assunto ${ }^{57}$. Espero com ele, dar mais fundamentos para entendermos o papel da festa - diretamente ligado aos percalços sociais e políticos locais - e contribuir para a escrita de uma ainda incipiente história local.

\footnotetext{
56 A definição de Fernand Braudel citando Lucien Febvre é esclarecedora do sentido de "longa duração" adotado na periodização: "Lucien Febvre, durante os dez últimos anos de vida, terá repetido: ' história ciência do passado, ciência do presente'. A história dialética da duração, não é à sua maneira explicação do social em toda a sua realidade e portanto atual. Valendo sua lição nesse domínio como uma proteção contra o evento: não pensar apenas no tempo curto, não crer que somente os atores que fazem barulho sejam os mais autênticos; há outros e silenciosos - mas quem já não o sabia". BRAUDEL, Fernand. Capítulo História e Ciências Sociais - a longa duração in Escritos sobre a História. Editora Perspectiva, $2^{a}$ edição, 1992 - São Paulo/SP, página 58.

57 O capítulo citado denomina-se "A importância da história local nas manifestações populares de São Luiz do Paraitinga" e vem logo a seguir.
} 
Mais uma vez, baseado na genialidade dos textos de Fernand Braudel, parto em busca da reflexão sobre uma história local, porém, sempre inserida em um contexto mais amplo. A periodização mais alongada não permite esmiuçar detalhes locais tão a fundo, por outro lado, abre um caminho imenso de reflexões comparativas com outras manifestações separadas no espaço e no tempo como algo ainda mais necessário. Aloca-se, dessa maneira, a festa do Divino de São Luiz do Paraitinga, reafirmando uma realidade local dentro de um universo mais amplo que é o da cultura popular brasileira:

"Cada um dentre nós sabe que toda a sociedade, todo grupo social, com relações próximas ou remotas, participa fortemente de uma civilização, ou mais exatamente, de uma série de civilizações superpostas, ligadas entre si e por vezes muito diferentes. Cada uma delas e seu conjunto nos inserem num movimento histórico imenso, de longuíssima duração, que é para cada sociedade, a fonte de uma lógica interna que lhe é própria..."58.

De qualquer forma, foi no arquivo do Estado de São Paulo que encontrei as principais fontes para essa tarefa de investigação da cidade luizense via festa do Divino. Lá se encontram preservadas muitas atas da Câmara Municipal, exemplares da imprensa da época - na minha opinião, a fonte mais rica preservada - e vários outros documentos que cobrem a maioria do período da virada do século XIX para o $\mathrm{XX}^{59}$. São documentos importantes para a reconstituição da festa e também ressaltam aspectos históricos, como ilustram os pedidos de licença para folias vizinhas esmolarem no município - indicando, inclusive, o relativo prestígio econômico que a cidade exercia perante cidades vizinhas ${ }^{60}$ e permitindo esse diálogo buscado entre o local e o contexto mais amplo.

Tanto no $\mathrm{CAPH}^{61}$ como nas caixas 9009 e 9050 do Arquivo do Estado encontram-se exemplares dos jornais "O Luizense", "O Parahytinga" e "O

\footnotetext{
58 BRAUDEL, Fernand. Capítulo III- História e tempo presente in Escritos sobre a História. Editora Perspectiva, $2^{\text {a }}$ edição, 1992 - São Paulo/SP, página 278.

59 Caixa 25 9033. Arquivo do Estado de São Paulo. S Manuscritos São Luiz do Paraitinga (avulsos XVII - XVIII- XIX-XX) população, religião, serviços públicos, terras.

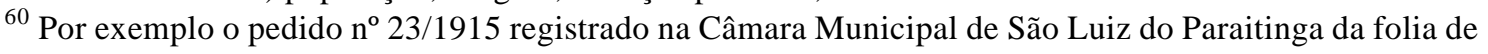
Cunha "em esmolar pela região da jurisdição da cidade de Paraitinga revelando-se a importância não só econômica, mas, religiosa de nosso grupo buscar auxílio em terra abençoada por seu povo e suas lavouras". O documento datava de 13 de maio de 1915 e era assinado pelo sr. José Benedito de Souza (contra-mestre da folia). Consta na caixa 9037 do Arquivo do Estado de São Paulo.

61 Centro de Apoio à Pesquisa Histórica da Faculdade de Filosofia Letras e Ciências Humanas da Universidade de São Paulo.
} 
Defensor”. Embora as edições preservadas tenham várias interrupções, são também fontes importantíssimas para um panorama da importância da festa na época caracterizada pela pujança do município ${ }^{62}$ A existência de testamentos, inventários e censos variados, tanto no arquivo do Estado como no arquivo do Fórum de São Luiz do Paraitinga, têm permitido analisar elementos importantes da história desta localidade e acabam suscitando questões de naturezas diversas. ${ }^{63}$

A documentação utilizada permitiu a orientação da pesquisa conforme o que propôs Martha Abreu quando, ao analisar a Festa do Divino na primeira metade do século XIX no Rio de Janeiro, buscou entender um pouco mais da história da então capital brasileira e não apenas encarar a festa como um problema histórico independente ${ }^{64}$. Estender este desafio a São Luiz do Paraitinga, mantendo as devidas proporções entre a erudição de um trabalho como o de Martha Abreu e o de um historiador iniciante, trouxe a motivação para a elaboração de um terceiro capítulo, que fará um histórico da Festa do Divino, contudo sempre dando ênfase à sua história na cidade luizense. Como citado anteriormente é dentro de uma festa como esta que encontramos, através dos conflitos e das transformações, um campo propício para entender as principais diretrizes da sociedade de cada época.

Estudar a Festa do Divino em São Luiz do Paraitinga tem sido também a possibilidade de reforçar a importância da história do cotidiano e das mentalidades, haja vista o peso que esta manifestação tem no dia-a-dia das pessoas, sendo capaz de modificar decisões importantes na história do município como um todo. Nunca se pode esquecer de uma característica que é comum aos pequenos municípios brasileiros, a força inquestionável dos eventos ligados à religião na realidade local. Com essa festa atividades temporárias e corriqueiras da comunidade são suspensas

\footnotetext{
${ }^{62}$ A própria existência de uma imprensa local que desde 1874 movimentava as discussões em São Luiz do Paraitinga e que nas primeiras décadas do século XX possuísse não só estas três publicações citadas, mas, jornais como "A ordem", "O Paraitinga", "O Eco" era um referencial da importância do município frente a uma imprensa praticamente inexistente na atualidade.

${ }^{63}$ Os censos têm-se revelados serem os principais documentos para questionar a afirmação corrente de uma cidade extremamente rica. Ainda não encontrei declarações de posses que justificassem grande poderio econômico e/ ou político nesta época. Poucas famílias de fazendeiros, como os "Domingues de Castro", "Manoel Bento", exerciam, sim, um destaque na sociedade, amparados por produções cafeeiras, posses na cidade e grandes fazendas na zona rural. Entretanto, a produção por eles apresentada, não é significativa quando comparamos com cidades como Bananal ou mesmo Taubaté.

${ }^{64}$ Martha ABREU. O império do Divino: festas religiosas e cultura popular no Rio de Janeiro, $1830-$ 1900. Rio de Janeiro: Nova Fronteira; São Paulo: Fapesp, 1999.
} 
em torno de um objeto específico, surgindo também um foco único, e gerando memória e identidade.

Dessa forma, a organização de uma festa como esta envolve quase a totalidade da comunidade. Ao mesmo tempo em que se contempla a coletividade com a união de quase todos em torno das simbologias referentes ao Divino, construindo-se uma forte identidade, são mantidas as relações de poder que regem a comunidade no interior da organização da festa. Daí a justificativa da necessidade de um estudo histórico da festa do Divino luizense, as relações entre os diversos segmentos sociais e o impacto provocado pelas decisões decorrentes das festas do Divino na situação política do município como um todo. Só como mais um exemplo, inclusive já citado, na época áurea do café no vale do Paraíba era comum um dos produtores luizenses mais prósperos ser escolhido como festeiro do Divino, assim como, hoje, ser festeiro é ainda sinônimo de status e poder de influência na comunidade.

Embora a festa de São Luiz já tenha sido objeto de estudo dentro de trabalhos importantes como a tese de Jaime de Almeida ${ }^{65}$ ou a dissertação de Flávia Albergaria Raveli ${ }^{66}$, foi sempre um desafio tentar penetrar mais nas discussões que permitissem explicar a sua força em um ambiente tão "hostil" às suas manifestações na atualidade. Embora a convivência que possuo com a cidade e esta manifestação tenha constituído um complicador no momento de analisar os fatos, também abriu caminhos ao facilitar a obtenção de entrevistas e permitir uma vivência mais próxima com os personagens principais nas suas últimas realizações.

Ao propor o estudo da minha cidade e daquela festa com a qual tanto me identifico, assim como com os mesmos símbolos ciados pela comunidade que sugiro investigar, senti uma grande incerteza sobre o quanto esta ligação poderia atrapalhar o "rigor acadêmico", o distanciamento que acreditava ser sempre imprescindível. Logicamente que um certo distanciamento - não confundido com

\footnotetext{
65 Jaime de ALMEIDA. Foliões (Tomos I e II). Tese de doutoramento apresentada ao departamento de História da FFLCH-USP. São Paulo, 1987. Este material apresenta um valiosíssimo trabalho de pesquisa documental estudando as várias festas, entre elas, a do Divino, no período de 1888-1918, em São Luiz do Paraitinga, destacando a figura do "folião" e sua relação com o sagrado.

66 Flávia Albergaria RAVELI. A reforma ultramontana e a Festa do Divino - São Luiz do Paraitinga entre os séculos XIX e XX. Dissertação de Mestrado, São Paulo, FFLCH-USP, 1999. Um trabalho preocupado sobretudo com os impactos da reforma ultramontana na Festa do Divino utilizando São Luiz do Paraitinga como estudo de caso.
} 
isenção - sempre deve ser buscado quando se procura analisar uma situação, mas, valorizar a oportunidade do contato direto com aqueles que fazem a festa, com os informantes de sua história, foi uma "lição" que as teorias da História Oral permitem confirmar, quebrando muitos de nossos "preconceitos metodológicos"67.

São algumas lições de História Oral, da escola baseada no NEHO-USP, que busquei adotar neste trabalho: a ética que deve prevalecer na relação com seu colaborador; as possibilidades de se relativizar aquela busca utópica pelo que seria a "verdade histórica" frente à riqueza proporcionada pela busca da experiência; a importância de se criar maiores vínculos com a sociedade estudada, implicando em um compromisso político de devolução. Situações que transformaram a metodologia da História Oral não mais como um mero instrumento de enriquecimento do discurso da História e, sim, como um outro campo do conhecimento responsável por fazer a própria História repensar muito de suas concepções.

Uma das possibilidades apresentadas por essa perspectiva foi ter a certeza de embora estar analisando uma cidade muito pequena, como São Luiz do Paraitinga, e um grupo bastante restrito quanto ao número de pessoas, ser possível discutir temas muito amplos, estendido às mais diversas realidades. Não há mais lugar para o intelectual universal, capaz de controlar conhecimentos infindáveis. É preciso buscar, como diz o célebre Foucault, uma pesquisa “diagnosticadora do presente, 68 .

A própria noção da busca dos resíduos da oralidade - prática prioritária no início de minha pesquisa - acabava passando uma imagem da busca de algo que "sobrou" sobre algo imóvel durante o tempo. Justamente o oposto das possibilidades abertas com as manifestações pautadas na oralidade. Buscar a comunicação no mundo dos indivíduos, acrescentando a interferência de diversas formas de

\footnotetext{
${ }^{67}$ A oralidade, através da História Oral, fica agora longe da acepção acessória e passa a ser protagonista em minha pesquisa, mostrando novos caminhos, contrapondo-se as outras formas de documentação que tomava como único caminho. E, mais importante, mostrando que, por mais que sempre digamos o contrário, investigar a oralidade com procedimentos sólidos como os apresentados pelo "Manual de História Oral" do prof. José Carlos Sebe (op. cit) possibilitam revelações até assustadoras de como somos objetivos em muitas práticas como pesquisadores, mesmo que sempre reafirmássemos os limites desta objetividade.

68 "Eu sou um diagnosticador do presente" frase de Michel Foucault emblemática deste perfil de intelectual que propõe. In ARTIÈRE, Philippe. Dizer a atualidade: o trabalho de diagnóstico em Michel Foucaul in GROS, Fréderic. (org). Foucault a coragem da verdade. São Paulo: Parábola Editorial, 2004. pg: $15-37$.
} 
mediação e expressão, a relação entre os sentidos e a interferência tecnológica, permitiu chegar, através da amplitude da discussão proporcionada pela História Oral, a uma postura que modificou aquela que eu possuía inicialmente. Pois, paradoxalmente defendendo um discurso de não neutralidade, da interferência do historiador, acabava, na prática, buscando - e como se fosse possível - uma espécie de "resgate do passado" da Festa do Divino luizense através das entrevistas.

Adotei prática semelhante na análise das fontes musicais, tão fundamentais à pesquisa quanto as anteriores. Os fundamentos aprendidos durante o curso "História, memória e música popular: dilemas, impasses e possibilidades de construção do conhecimento histórico"69 , ministrado pelo prof. dr. José Geraldo Vinci de Moraes, mostraram como no trabalho com a oralidade as possibilidades que surgem a partir do objeto - no caso, a música - relacionam-se com os diversos discursos históricos.

“ (...) Ou seja, a canção e a música popular poderiam ser encaradas como uma rica fonte para compreender certas realidades da cultura popular e desvendar a história de setores da sociedade pouco lembrados pela historiografia."70

Desafio feito, acabei tomando contato mais direto com a musicalidade produzida pelos grupos folclóricos, como também passei a atentar para a produção de grupos como o "Paranga"71, que utilizava-se justamente desta musicalidade regional como proposta de trabalho dentro de círculos importantes da música popular brasileira. Buscar estas fontes musicais durante a pesquisa transformou-se na busca da compreensão do mundo e das relações sociais destes grupos envolvidos na festa do Divino.

“ (...) La musique offre un faisceau d'investigations particulièrement riche. Elle ne se réduit pás à un createur et à une oeuvre. Sés médiateurs que sont l'instrument et l'interpréte (professionnel et amateur), sés modes de diffusion (...) et ses consommateurs (...) méritent également d'être questionnés". 72

\footnotetext{
${ }^{69}$ Disciplina oferecida pelo programa de pós graduação em História Social da Universidade de São Paulo no primeiro semestre de 2006.

70 MORAES, José Geraldo Vinci de. História e música: canção popular e conhecimento histórico. In Revista Brasileira de História, São Paulo, volume 20, número 39, página 203-221, 2000.

71 Grupo musical luizense ainda em atividade que surgiu no fim dos anos 70 e percorreu espaços importantes da música brasileira como o teatro Lira Paulistana tendo como proposta fundamental a afirmação da musicalidade luizense e a importância de seus grupos folclóricos para a musicalidade regional brasileira.

${ }^{72}$ CHIMÈNES, Myriam. Musicologie et histoire. Frontière ou 'no man's land entre deux disciplines. In Revue de Musicologie, Tome 84, nº 01, 1998. pág: 75 e 76.
} 
Obviamente a relação entre música popular e cultura popular, tão marcante dentro da festa luizense, transcende explicações restritas às análises da linguagem musical e vai de encontro à crítica acima citada de Myriam Chimènes. Esta musicóloga francesa dirigiu-se criticamente aos próprios companheiros de profissão justamente pelo distanciamento que seus estudos mantinham com os cientistas humanos de áreas próximas. Que esta atitude sirva de lição...

E falo isso tudo, ademais, assim como com a oralidade, destacando a importância da musicalidade presente nas manifestações do Divino e não analisada de forma mais completa no início da pesquisa. Era traído, na prática, por uma perspectiva com a qual ao estudar essa musicalidade, fazia com que parecesse uma espécie de acessório dentro das festividades. Não percebia, analisando um canto de folia do Divino luizense prioritariamente através da crítica da letra, uma atitude incoerente, percebendo agora ser a letra um dos fatores menos importantes dentro de um desses cantos.

Afinal, na prática, estava reproduzindo a principal crítica que fazia aos trabalhos mais recentes nessa área de estudo e sobre a quase totalidade das pesquisas existentes até recentemente, versando, de alguma maneira, sobre música popular brasileira. A tônica tem sido se manter longe das complexas discussões interdisciplinares que este campo do estudo poderia provocar ${ }^{73}$.

São várias as relações, como exemplos a serem citados, entre os grupos de folia de São Luiz do Paraitinga, suas músicas, apresentações e questões da sociedade luizense não só presentes na letra de seus cantos, mas na constituição dos grupos, nas relações de poder formadas a partir de suas apresentações, suas relações sociais, entre muitos outros motes, principalmente aqueles relacionados às reinterpretações desta fonte musical por grupos musicais ligados aos principais meios de comunicação e às "linguagens musicais" mais antenadas com a produção contemporânea da indústria fonográfica. Discutir os prós e contras desta

\footnotetext{
${ }^{73}$ Podemos pesquisar na historiografia da música popular brasileira e encontraremos sobretudo análises centradas em discussões literárias, ou focadas especificamente em questões musicais. Trabalhos mais recentes, entretanto, vêm modificando esta realidade e serviram de exemplo para o trabalho com esta fonte. Cito como exemplo principal deste aprofundamento da análise sociedade $\mathrm{X}$ música o trabalho de BESSA, Virginia. Um bocadinho de cada coisa. Trajetória e obra de Pixinguinha. História e música popular no Brasil dos anos 20/30. São Paulo: DH/FFLCH/USP, 2006.
} 
possibilidade cada vez mais real no dia-a-dia desses grupos populares tornou-se tarefa obrigatória e será a tônica do capítulo IV desta dissertação.

Por fim, um dos trabalhos que muito ajudou também desde os primeiros passos da pesquisa foi o do pesquisador luizense Marcelo Toledo ${ }^{74}$. Procurando ressaltar a importância existente na relação direta do sujeito que participa dessa manifestação com o sagrado, mostrou o quanto isso se configura como elemento crucial para entendermos a importância da festa para seus personagens. Toledo reafirma como São Luiz do Paraitinga tem ficado à margem do surto de transformações e progressos com os fenômenos da modernização e industrialização, favorecendo, em sua concepção, a manutenção de padrões mais tradicionais de convivência, sobretudo, os relacionados à produção de uma "cultura religiosa".

A forte manutenção de muitas tradições frente à "invasão" da cultura de massa, o que pode ser constatado pelas antenas parabólicas em toda a zona rural - e poderia citar muitos outros exemplos -, mostra ser necessário refletir se essa invasão e a tentativa de dominação da cultura popular é algo concreto e cuja tendência é a de dominação ou se o processo trata de uma importante transição e adaptação, inclusive, adicionando-se alguns elementos da dita modernidade em suas representações.

Seria assim "apenas" mais um desafio frente às variadas situações de conflito já superadas pelos membros constituintes dessa "poderosa" cultura que é a popular. Aqui é bom lembrar a superação do desafio representado pelos ideais republicanos, na virada do século XIX para o XX em nosso país, que pregavam uma sociedade modernizante e procuravam apagar tudo que representasse o atraso, com destaque para as manifestações populares do passado recente de nosso país.

Um fato marcante até esse momento da pesquisa e que gostaria de ressaltar lembrando que a parte do material documental ainda carece de análise mais cuidadosa, que poderá ainda enriquecer o texto futuramente - é o sentimento de devolução social desse projeto. A comunidade não só tem ajudado no dia-a-dia da pesquisa como apóia a iniciativa imensamente. Sempre tenho sido questionando sobre os progressos e dúvidas que naturalmente vão aparecendo. Fiquei

\footnotetext{
${ }^{74}$ Marcelo Henrique Santos TOLEDO. Espaços individuais e coletivos da sacralidade nos meios populares. Dissertação de mestrado apresentada ao departamento de Ciências da Religião da PUC-SP. São Paulo, 2001.
} 
extremamente lisonjeado de ter a discussão deste trabalho inserida, por exemplo, na montagem do plano diretor da cidade, percebendo muitas transformações que esta pesquisa possa trazer, mesmo sabendo de todas suas limitações. ${ }^{75}$

E fico esperançoso pelo futuro - mesmo levando em conta todas as dificuldades da modernidade como já bastante reafirmado - justamente pela preocupação evidente em todos os debates que vêm acontecendo na cidade atualmente $^{76}$, cuja tônica tem sido justamente a necessidade da manutenção deste perfil cultural do município que garantiria à população luizense afirmar sua identidade e seu espaço em uma realidade econômica extremamente difícil. O debate cada vez mais presente sobre patrimônio imaterial faz todo o sentido na realidade luizense e gostaria muito que fosse um caminho sugerido pelo poder público dentro dos próximos anos.

Seria, dessa forma, um caminho frutífero adotar a festa do Divino e suas várias manifestações populares como um patrimônio local legitimado juridicamente e com a possibilidade de abertura para se desenvolverem projetos de apoio à cultura local. Um dos objetivos primordiais dessa pesquisa é, portanto, ransformar esse trabalho em mais uma voz clamante pelo espaço de representação dos populares, envolvendo ainda mais no dia-a-dia da cidade e da região essa já pulsante atuação da comunidade luizense. Como aponta Joaquim Falcão:

“ Ninguém, pois, ignora que a globalização aumenta a tensão entre o nacional e o internacional, entre o exógeno e o endógeno, a metrópole e a província, entre padrões culturais globalizados e padrões comunitários locais. A grande indagação é como essa tensão vai se resolver e se institucionalizar. (...) como participar autonamente de uma cultura e de uma economia cada vez mais globalizadas de modo a proteger e expandir seus valores, sua prática e sua identidade cultural? Como preservar uma autonomia decisória, capaz de escolher o que melhor lhes convém?",77

\footnotetext{
75 Embora ainda não tenha sido aprovado pela Câmara Municipal local a tônica da montagem do plano diretor de São Luiz do Paraitinga tem sido muito animadora para o futuro da cultura popular na cidade. Coloca-se como um plano inovador, levando em conta as especificidades de um pequeno município e, neste caso particular, de uma cidade que deve primar pela valorização de sua cultura. Tem recebido o apoio da Fundação da Unesp/SP-Araraquara em sua elaboração e foram realizados diversos encontros com a comunidade, tanto urbana quanto a rural, geridas por um grupo com participantes de vários setores da sociedade.

76 Elaboração do plano diretor, discussões do Conselho Municipal do Turismo, projetos montados pela secretaria de educação municipal entre outras iniciativas.

77 FALCÃO, Joaquim. Patrimônio imaterial: um sistema sustentável de proteção. In Revista Tempo Brasileiro, número 147. Rio de Janeiro, outubro/dezembro 20001. páginas 163-180.
} 
Quero acreditar que mesmo com todos os percalços a ela apresentada, a cultura popular brasileira tem respondido a esses desafios. E São Luiz do Paraitinga coloca-se como exemplo ímpar nessa questão. 


\section{Capítulo II - A importância da história local nas manifestacões populares de São Luiz do Paraitinga}

Para entender como a Festa do Divino de São Luiz do Paraitinga vem se mantendo como forma de manifestação da cultura popular na atualidade, é fundamental aprofundar as pesquisas sobre essa cidade e seus sujeitos. Não imaginava - e nem é esse mesmo o propósito principal desta pesquisa - o quanto seria necessário uma acurada atenção a determinadas questões históricas do município, extremamente elucidativas para o entendimento da festa do Divino Espírito Santo luizense.

A história de São Luiz do Paraitinga é reveladora do poderio exercido por uma elite econômica frente a uma população extremamente pobre. Percebemos um movimento de troca destas elites conforme os ciclos econômicos locais - com destaque para o cafeeiro e o da pecuária leiteira - com os respectivos cargos de destaque políticos e sociais se readequando às novas situações. Sempre ligadas a essa elite, principalmente, por laços profissionais exploradores, mantém-se aquele "statos quo" de pobreza, a verdadeira marca do dia-a-dia da maioria da população na história local.

São Luiz do Paraitinga, como quase a totalidade dos pequenos municípios brasileiros, era uma cidade praticamente abandonada pela "governança lusobrasileira" desde seu processo de fundação, em fins do século XVIII, confirmando a dificuldade de controle do imenso território brasileiro mesta época. É coincidente a este momento uma crise do sistema colonial como um todo no contexto mundial atingindo, diretamente, a administração do governo brasileiro da época. Desta forma, localidades como a que estamos estudando, nascentes nesse contexto conturbado, acabam tendo na grande maioria das vezes, uma história inicial com sucessões de golpes políticos, pobreza e isolamento ${ }^{78}$.

\footnotetext{
78 Veremos mais a frente o quanto foi difícil para São Luiz consolidar a sua própria população, uma organização política e uma vocação econômica que desse suporte aos seus habitantes. Mais uma vez, indico o trabalho pioneiro da história da fundação da cidade de São Luiz do Paraitinga e que sustenta essas afirmações: ALMEIDA, Jaime de. Foliões (Tomos I e II). Tese de doutoramento apresentada ao departamento de História da FFLCH-USP. São Paulo, 1987.
} 
Só para exemplificar melhor esse momento histórico específico, ao mesmo tempo em que os Estados Unidos da América proclamam sua independência (1776), a França põe fim ao Antigo Regime pela sua Revolução de 1789, Portugal apresenta-se como uma nação empobrecida pela nova ordem econômica que se estabelecera. O sistema explorador, mercantilista, vai sendo substituído, sobretudo, pelo exemplo inglês do "livre-comércio". Todos os impactos conhecidos da utilização das novas fontes de energia, advindas acima de tudo da Revolução Industrial, acabam instaurando uma "nova ordem mundial". Boris Fausto elenca uma abertura, graças a essa nova situação econômica, de acordos comerciais de contrabando e alianças com comerciantes locais na colônia brasileira fatais à possibilidade de uma administração dentro da visão modernizadora que a linha do chamado "livre-comércio" propunha, passando a impor sérias dificuldades de organização mesmo da governabilidade do território brasileiro. ${ }^{79}$

Como consequiência disso tudo, a administração colonial brasileira - situação ainda constante no pós-independência -, tinha grandes dificuldades de controlar seu próprio território. Elementos estruturais como a posse de terras, o controle fiscal, uma justiça atuante, o oferecimento de serviços básicos à população, entre outras questões diversas, eram muito precários.

A própria Igreja Católica - instituição fundamental no processo de institucionalização das cidades e dos poderes com uma história marcada por intervenções políticas na sociedade brasileira - só enviou o primeiro pároco efetivo da cidade no início do século $\mathrm{XX}^{80}$. $\mathrm{E}$ a todo momento, constituindo uma marca indiscutível na história luizense, encontramos um forte cunho religioso no dia-a-dia da população. Torna-se imprescindível nunca perder de vista qual o cerne desta religiosidade, regida acima de tudo pelos próprios populares e incluindo elementos das diversas culturas que aqui entraram em contato, constituintes da identidade de nosso país como um todo.

\footnotetext{
79 FAUSTO, Boris. Historia Concisa do Brasil. São Paulo: Editora da Universidade de São Paulo, Imprensa Oficial do Estado, 2001. páginas 58-62.

80 No ano de 1916, chega à cidade o padre italiano Monsenhor Ignácio Gióia, hoje, um dos principais personagens da história da cidade. Até então a cidade era doutrinada sobretudo por missionários o que contribuiu, na minha opinião, para a solidificação de um catolicismo pautado em crenças populares e sempre distante do controle da instituição religiosa. A relação de tensão com a cultura popular é extremamente marcante na atuação do Monsenhor Gióia e seu papel na organização das festas do Divino são exemplares desta relação constantemente conflituosa entre Igreja Católica e a religiosidade popular.
} 
Como diz Laura Mello e Souza sobre um tempo de nosso país em que nem se previa o estabelecimento da cidade luizense:

"Avançando pelos séculos XVII e XVIII, o desenvolvimento do processo colonizatório propiciava maior interpenetração entre religiosidade européia, africana e ameríndia; enquanto a Europa tridentina se esforçava em depurar a religião e 'limpá-la' das reminiscências folclóricas, a colonização européia dos trópicos impunha o sincretismo' ${ }^{\text {, } 1 .}$

Contudo, é o próprio retrato deste sincretismo que encontraremos no dia-dia da cidade luizense logo que constituída. Características aliás, que atravessaram os séculos XIX, XX e estão presentes ainda nas mais diversas situações e manifestações dos dias atuais desta comunidade.

Podemos inclusive ir mais longe, nessa mesma constatação da atuação do popular, quando nos debruçamos especificamente sobre o início do século XX. Esse é o tempo do auge econômico da cidade luizense, propiciado, sobretudo, pelo ciclo cafeeiro que marcou todo o vale do Paraíba paulista e fluminense ${ }^{82}$. Seguindo a mesma abordagem proposta por Marina de Mello e Souza para analisar a cidade fluminense de Paraty, por cujo porto era evacuada parte da produção cafeeira do vale do Paraíba, podemos dizer que como lá, São Luiz do Paraitinga também tinha, no início do século XX, algumas feições próximas às das sociedades européias do século XVIII, analisadas por Peter Burke sob o ponto de vista do espaço da cultura popular e das relações com os outros estratos da sociedade. ${ }^{83}$

Reforça-se, mais uma vez, toda a discussão apresentada no capítulo anterior sobre a temporalidade e dinâmica diferenciada deste "mundo" do popular. E também os próprios desafios que sempre se apresentam, contudo, insuficientes para brecar a continuidade de algumas tradições populares marcantes deste "mundo" que se reinventa a todo o momento.

\footnotetext{
${ }^{81}$ SOUZA, Laura de Mello e. O diabo e a terra de Santa Cruz: feitiçaria e religiosidade popular no Brasil Colonial. São Paulo: 1986, Companhia das Letras. Pg 17.

82 Discutirei a frente os limites da riqueza deste período. É inegável tratar-se do principal momento econômico da história de São Luiz do Paraitinga, o que não se pode continuar generalizando é a idéia de que toda a população compartilhava das rendas advindas da atividade cafeeira.

83 SOUZA, Marina de Mello. Parati: a cidade e as festas. Rio de Janeiro: Editora UFRJ/ Tempo Brasileiro, 1994.; BURKE, Peter. Cultura Popular na Idade Moderna. São Paulo: Companhia das Letras, 1989.
} 
Retomo Marina de Mello e Souza em seu estudo sobre Paraty constatando uma situação comum a esta cidade fluminense e a cidade de São Luiz do Paraitinga e, por que não, a diversas situações da Europa estudada por Peter Burke. É essa constante e complexa relação entre o erudito e o popular presente em diferentes momentos e espaços de nossa história:

"A pequena elite, que estudava na capital, editava o semanário, ocupava os cargos da administração municipal e estava à frente do comércio, participava de algumas das manifestações da cultura popular, levadas a cabo por lavradores, pescadores e empregados subalternos. Mas muitas manifestações da cultura popular, principalmente as realizadas pelos negros e moradores da roça, eram proibidas principalmente no perímetro urbano." $\$ 4$

Sempre encontramos a exaltação até exacerbada dos grupos populares na história da cidade luizense. Entretanto, quando pesquisamos a participação política na direção da comunidade esse destaque dos populares dificilmente aparece. É a mesma realidade de Paraty e da maioria dos casos onde o popular dificilmente ocupa os meios de controle monopolizados por uma elite governante, estabelecida há muito tempo. Ressalta-se, sim, na história luizense, a participação de dezenas de grupos de congadas e moçambiques em suas festas populares, com destaque justamente nas do Divino. Mas essa exaltação é bem diferente da correspondente dificuldade de atuação que possuíam, em uma verdadeira exclusão da maioria dos processos políticos da comunidade.

“ Sempre o controle político de São Luiz do Paraitinga esteve na mão dos grandes produtores e daqueles ligados à política real nos primeiros tempos da cidade". ${ }^{85}$

Muito se fala, na atualidade, da falta de apoio aos grupos folclóricos como a principal causa do desaparecimento da maioria das manifestações populares. Porém, fica patente a permanente dificuldade durante todo o tempo de existência destes na história da sociedade luizense, não sendo essa adversidade atual uma situação nova. E, justamente a capacidade da cultura popular de superação de situações como esta, torna-a ainda mais forte e consolidada.

\footnotetext{
${ }^{84}$ Marina de Mello e SOUZA. op cit, (1994). pg 21.

${ }^{85}$ Frase não assinada da primeira página do jornal local "O Luizense" publicada na comemoração do $152^{\circ}$ aniversário da cidade em 08 de maio de1921. Microfilmado e arquivado pelo Centro de Apoio a Pesquisa Histórica (CAPH) da USP.
} 
Por exemplo, na atualidade, mais uma vez como o próprio caso de Paraty analisado por Marina de Mello e Souza, o advento do turismo vem despertando nos poderes públicos de São Luiz do Paraitinga a preocupação em reforçar uma imagem histórica de autenticidade, expressa nas manifestações tradicionais. Tem sido comum, pelo menos na maioria dos discursos políticos, a ênfase na importância da cultura popular e de grupos folclóricos como os estudados nesta pesquisa. Entretanto, será que se trata de um apoio efetivo? A ênfase atualmente dada pelos poderes públicos, pautada sobretudo pelo aproveitamento do turismo, não parece ser muito diferente dos mecanismos pelos quais os senhores do café permitiam um momento de exceção à constante opressão das fazendas escravocratas, consentindo na apresentação de danças e músicas populares, por exemplo, no decorrer das festas religiosas. Esta, na verdade, é uma das discussões fundamentais que pretendo apresentar no capítulo IV - discutindo a festa do Divino na atualidade - e que mostra os limites dessa valorização, clamando por mecanismos mais efetivos de apoio cultural. Mas, por ora, aproximemos-nos da história da cidade...

\section{1 - As tropas do ouro e o papel de São Luiz do Paraitinga como entreposto comercial do vale do Paraíba.}

A história da ocupação do território de São Luiz do Paraitinga iniciou-se com uma sesmaria concedida ao capitão Mateus Vieira da Cunha e a João Sobrinho de Moraes, em 5 de março de 1688, já com a finalidade de povoamento e atendendo a necessidade da expansão dos domínios na capitania de São Paulo rumo à serra do $\operatorname{mar}^{86}$. Esta primeira tentativa acabou sendo frustrada em seu objetivo inicial de rápido povoamento, entretanto, foi o primeiro passo do que seria futuramente a ocupação do então município luizense. Desta forma, embora a região da atual cidade luizense só tenha legitimado seu povoamento em 08 de maio de 1769 - data comemorada como marco da fundação da cidade - pelo Sargento-mór Manuel Antônio de Carvalho - denominada então, São Luiz e Santo Antonio do Paraitinga -

\footnotetext{
${ }^{86}$ TOLEDO, Marcelo Henrique Santos. Espaços individuais e coletivos da sacralidade nos meios populares. Dissertação de mestrado apresentada ao departamento de Ciências da Religião da PUC-SP. São Paulo, 2001.
} 
, elevada à condição de Vila em 31 de março de 1773 e emancipada politicamente em 30 de abril de 1857, esse período inicial de ocupação, nos traz muitos elementos importantes que vão marcar a identidade do município futuramente. Assim, faz parte também da história da cidade, mesmo tratando-se de um período anterior à sua própria data de fundação. ${ }^{87}$

Mesmo retrocedendo a essa primeira tentativa de ocupação, ao tempo da doação da sesmaria que hoje engloba o território luizense, em fins do século XVII, quero reconhecer a importância para a historiografia da cidade de autores que já escreveram sobre a história de São Luiz do Paraitinga como Marcelo Toledo, colocando o momento da nomeação do Sargento-mór Manuel Antonio de Carvalho, em fins do século XVIII, como marco primordial para o início da história da cidade. Gostaria apenas de acrescentar que esse momento da formação da povoação em fins do século XVIII não foi fruto do acaso, pois estava consolidando tentativas de ocupação de décadas anteriores e, neste novo momento, estava totalmente apoiado por uma nova política administrativa de Portugal, comandado pelo Primeiro Ministro Marquês de Pombal. O próprio Marcelo Toledo afirma em sua pesquisa que ao nomear Morgado de Matheus para governar a Capitania de São Paulo o propósito do governo português era mesmo o de imprimir um maior controle na então difícil defesa do território brasileiro ${ }^{88}$. Daí, o afinco com que se procedeu à fundação de novas cidades e à ampliação da organização burocrática.

$\mathrm{Na}$ verdade, esse ato de legitimação transformando territórios habitados em futuras cidades, representava, acima de tudo, um ato formal da proposta do controle português sobre o território brasileiro. Era cada vez mais freqüente, e não menos fundamental para a crescente economia de um país em formação, a organização do espaço e das relações sociais, sempre com vistas a um maior controle pelo Estado. Populações foram se dispersando pelo vastíssimo território brasileiro e a institucionalização de cidades foi uma necessidade básica sob o ponto de vista do

\footnotetext{
${ }^{87}$ O livro São Luiz o ano inteiro elaborado pelo Comitê Pró Associação para o Desenvolvimento Cultural e Ambiental de São Luiz do Paraitinga organizado por TOLEDO, Marcelo Henrique Santos. Taubaté: Vogal Editora, 1997, traz um resumo destas etapas anteriores à definitiva emancipação da cidade. Embora inicie sua discussão a partir de 1769 , foi o maior estímulo para que eu retrocedesse na periodização, pois mostrava com ênfase a importância das tropas para a escolha de uma nova povoação a ser estabelecida. E não seriam novos caminhos a serem criados na Capitania de São Paulo. A busca passava a ser de consolidação dos roteiros estabelecidos pela ocupação bandeirante desde o século XVII.

${ }^{88}$ Idem nota anterior, páginas 9 a 12.
} 
controle estatal. É bom sempre lembrar que a região da atual cidade de São Luiz do Paraitinga localizava-se em local estratégico no escoamento de grande parte da produção da capitania paulista rumo ao litoral.

Principalmente por essa importância geográfica, a região do vale do Paraíba como um todo começa a receber uma preocupação especial da Coroa Portuguesa, principalmente, a partir do aumento da extração aurífera, no início do século XVIII. Em sua obra mais conhecida - "História Econômica do Brasil" - Caio Prado Júnior demonstra como essa atividade muda os rumos administrativos portugueses com relação a sua colônia:

“ O interesse da metrópole pelo Brasil e o desenvolvimento conseqüente de sua política de restrições econômicas e opressão administrativa tomarão considerável impulso sobretudo a partir de princípios do século XVIII quando se fazem na colônia as primeiras descobertas de jazidas auríferas. (...) Ao contrário do que se deu na agricultura e em outras atividades da colônia (como na pecuária), a mineração foi submetida desde o início a um regime especial que minuciosa e rigorosamente a disciplina". ${ }^{89}$

Estava dada a necessidade de novos caminhos de escoamento desta riqueza, que vinha em quantidades cada vez maiores da região mineira, assentadas em uma estrutura mais organizada. Pouco a pouco foram se reforçando núcleos populacionais pois o estabelecimento de cidades permitia não só uma maior estrutura para o transporte do ouro como um maior controle burocrático desta atividade. Mas, não se pode reduzir apenas à questão do transporte do ouro a ocupação desses novos territórios que englobavam o atual vale do Paraíba. Era um momento de crescimento da exploração do território brasileiro de uma forma geral e a fertilidade das terras paulistas foi um impulso fundamental para a ocupação do vale do Paraíba naquele momento da história.

Jaelson Trindade aponta em sua pesquisa sobre São Luiz do Paraitinga justamente esse papel de "entreposto comercial" exercido pelo vale do Paraíba como um todo. Aliás, uma posição consolidada ainda mais com o passar do tempo e que

\footnotetext{
${ }^{89}$ PRADO JUNIOR, Caio. História Econômica do Brasil. 43ª edição - São Paulo: Brasiliense, 1998. páginas 56-65.
} 
marca a história de São Luiz do Paraitinga como discutiremos logo a frente. ${ }^{90}$ Aproximando-nos do final do século XVIII, essa região valeparaibana chegará a ser classificada como a "mais importante da capitania"91. Na verdade, uma série de características fazia o vale do Paraíba assumir uma importância ímpar para a capitania de São Paulo naquele momento. Por exemplo: havia sido um dos caminhos das bandeiras na exploração do território; exercera função fundamental para o escoamento dos valiosos carregamentos auríferos sobretudo sob o esquema de tropas; chegava, na proximidade do século XIX, como a região com povoação mais elevada e com o maior número de vilas estabelecidas na capitania.

A importância exercida pelo transporte em sistemas de tropas na região luizense relaciona-se de forma muito interessante também ao registro de um grande número de manifestações culturais relacionadas a esta atividade desde o século XVII, ainda presentes. Citarei mais à frente semelhanças deste sistema com diversas manifestações relacionadas às festas do Divino luizense, com destaque para a peregrinação da folia do Divino, mantenedora da mesma estrutura dos agrupamentos tropeiros. É fácil perceber, na atualidade, como são marcantes na cultura de toda a população dessa região paulista e fluminense, muitas soluções coletivas, de certo modo até improvisadas, frente às dificuldades apresentadas pelo cotidiano. A mesma lógica que sustentava o sistema tropeiro como um meio eficaz em termos econômicos e sociais nos primeiros tempos do país. ${ }^{92}$

Para termos uma melhor noção geográfica do caminho ocupado pelas tropas desde o tempo da exploração aurífera até a produção cafeeira, temos abaixo a descrição feita por Jaelson Trindade deste espaço. Gostaria de ressaltar novamente a importância de uma situação que acabou por organizar o espaço do que hoje conhecemos como cidades valeparaibanas:

"De Taubaté às Minas, o traçado do caminho se fazia pela 'garganta' do Embaú, acima de Guaratinguetá. No sentido da marinha, as diferentes trilhas se concentravam em poucas diretrizes. Do planalto, ligando-se com a estrada

\footnotetext{
90 TRINDADE, Jaelson Bitran. No caminho do Paraitinga in São Luiz do Paraitinga - Publicação $n^{\circ} 02-$ Conselho de Defesa do Patrimônio Histórico Arqueológico, Artístico e Turístico do Estado Condephaat. Secretaria da Cultura, Ciência e Tecnologia do Governo do Estado de São Paulo, 1977.

${ }^{91}$ Idem anterior, página 07.

92 Talvez a festa mais importante na atualidade com os signos deste momento histórico seja a "Festa do Tropeiro", realizada anualmente na cidade de Jambeiro. A culinária do vale do Paraíba como um todo também é muito marcada pela imagem "tropeira".
} 
que de São Paulo ia até Taubaté e daí as Minas, uma vai alcançar a porção do território, agora chamada "zona do Alto Paraíba" região do rio Paraitinga: seguia até a 'borda do campo da Facam' (área de Cunha) onde um ramo dela, no lugar chamado 'Encruzilhada', preferia a direção de Ubatuba, enquanto o outro seguia também em direção ao mar, rumo a Parati.",93

A região onde encontramos especificamente a cidade de São Luiz do Paraitinga pertence a esta citada "Zona do Alto Paraíba"94. Localizada no topo da serra do Mar, "integra o conjunto de planaltos, serras e escarpas do Brasil tropical atlântico"95. Para se chegar ao porto de Ubatuba, enfrentava-se uma dificílima travessia em meio à mata fechada da serra do mar. Vem daí mais um motivo fundamental à constituição de um núcleo em uma região cortada pelo rio Paraitinga, permitindo apoio aos grupos quando já relativamente próximos do destino final das expedições. ${ }^{96}$

Surge assim, bem antes do reconhecimento como cidade, a principal vocação do futuro município de São Luiz do Paraitinga, realizada ainda pelos primeiros povoadores: a constituição de uma localidade de apoio para as tropas e todo tipo de escoamento de produção que rumava aos portos de litoral, mais especificamente, neste caso, ao porto de Ubatuba. A dificuldade apresentada pelos aspectos geográficos da região, foi o próprio impulso da forma de transporte baseada nos lombos dos burros e nas longuíssimas jornadas dos "tropeiros". 97 Nunca esquecendo a inclusão entre esse grupo de "tropeiros" dos escravos, como de se imaginar, a quem cabiam sempre as labutas mais árduas das expedições.

\footnotetext{
93 TRINDADE, Jaelson Bitran. No caminho do Paraitinga in São Luiz do Paraitinga - Publicação $n^{\circ} 02-$ Conselho de Defesa do Patrimônio Histórico Arqueológico, Artístico e Turístico do Estado Condephaat. Secretaria da Cultura, Ciência e Tecnologia do Governo do Estado de São Paulo, 1977. Páginas 08 e 09 citando uma Carta para Mendos de Foyos Pereira, Secretário de Estado, sobre as pedras minerais de D. Rodrigo de Castello- Branco in Anais da Biblioteca Nacional, vol LVII, pág 173, apud Tricentenário de Parati, DPHAN nº 22, MEC, Rio de Janeiro, 1960 - pág 05.

94 Referência de Pasquale Petrone localizando São Luiz do Paraitinga geograficamente. PETRONE, Pasquale. A região de São Luiz do Paraitinga (Estudo de geografia humana) in Revista Brasileira de Geografia, ano XXI, julho-setembro de 1959, número 3, página 3.

${ }^{95}$ Petrone, Pasquale, idem nota anterior.

96 O núcleo urbano que surgiu no território de São Luiz do Paraitinga localiza-se a cerca de cinqüienta quilômetros da cidade de Ubatuba.

97 O termo "caminhos aspérrimos" ficou conhecido como sinônimo do trecho enfrentado pelas tropas no transporte do ouro na região do Vale do Paraíba. Este termo está citado por CASAL, Manuel Ayres de. "Corografia brasilica. Fac-simile da edição de 1817, introdução de Caio Prado Júnior. Rio de Janeiro, Imprensa Nacional, 2 volumes, 1945/1947.
} 
Fica confirmado como praticamente todo o povoamento do vale do Paraíba está diretamente inserido no contexto expansionista do controle territorial e econômico da Colônia Portuguesa, cuja principal vocação era a atividade de exploração dos recursos naturais. ${ }^{98}$ E por todo o século XVII e XVIII não havia outra forma para o escoamento destes bens senão o árduo trabalho das tropas.

Os autores Tom e Thereza Maia atribuem à movimentação das tropas o impulso para o surgimento do comércio de "beira de estrada" e, conseqüentemente, de povoamentos e cidades. Reafirmam justamente a situação que venho descrevendo como o primeiro passo na constituição da cidade luizense:

“ (...) assim surgiu Silveiras, do Rancho das Silveiras. Assim cresceram São José do Barreiro, Areias, Cunha, Lagoinha, São Luiz do Paraitinga, Bananal." 99

Com o advento do café no vale do Paraíba - sobretudo em fins do século XVIII e início do XIX -, veremos essa movimentação comercial ainda mais pujante e o desenvolvimento cada vez maior de cidades como as citadas por Tom e Thereza Maia. O que provavelmente não permitiu uma maior ocupação do território vale paraibano já no século XVII e início do XVIII foi uma mudança da rota do ouro, marcada pela descoberta do chamado "Caminho Novo"100, desviando para outras regiões a circulação dos carregamentos de ouro que cortava anteriormente trechos do território paulista como a região luizense. Agora, com a abertura por Garcia Rodrigues Pais, no início do século XVIII, de um novo trecho ligando diretamente

\footnotetext{
${ }^{98}$ SANTOS, Carlos Murilo Prado. “Cap. 7 No caminho do ouro: o processo de urbanização do vale do Paraíba do Sul” in O reencantamento das cidades: tempo e espaço na memória do patrimônio cultural de São Luiz do Paraitinga/SP. Dissertação de mestrado. Universidade Estadual de Campinas, Instituto de Geociências, 2006. Baseado na argumentação de MULLER, Nice Lecocq. O fato urbano na bacia do Paraíba do Sul. Rio de Janeiro: Fundação IBGE, 1969.

99 MAIA, Tom; MAIA, Thereza Regina de Campos Maia. O folclore das tropas, tropeiros e cargueiros no Vale do Paraíba. Rio de Janeiro: Funarte: Instituto Nacional do Folclore: São Paulo: Secretaria do Estado da Cultura: Universidade de Taubaté, 1981. Acredito ser necessário uma ressalva relativa à exclusão da cidade de Lagoinha desse momento histórico, parte constituinte do território do município de São Luiz do Paraitinga até meados do século XX e que não conta, até então, com registros que comprovem a existência de algum arraial, ou passagem de tropas neste momento histórico analisado.

${ }^{100}$ Nem por isso cessam as tentativas de caminhos alternativos no vale do Paraíba da nova rota do ouro, por exemplo, um que abriria uma nova ligação entre Guaratinguetá e o porto de Parati. Vide Arquivo do Estado, pasta SESMARIAS, vol II, pág 95 e 99. Na pasta SESMARIAS, vol III, página 400 encontramos ainda muitos pedidos de sesmarias visando à ocupação populacional de um território economicamente promissor e que fundaria muitos municípios posteriormente.
} 
Minas Gerais ao Rio de Janeiro, ocorre naturalmente um deslocamento populacional pela viabilidade econômica maior dessas regiões próximas a este novo caminho. ${ }^{101}$

“ A abertura desse caminho representou uma verdadeira revolução no sistema de comunicações com as Gerais. Representava uma diminuição de distância e uma economia de tempo assombrosas. O caminho paulista demorava dois meses, o 'caminho Velho' do Rio de Janeiro quarenta e três dias, e o 'caminho novo' dezessete e depois doze dias. "102

Mesmo com a mudança da rota e o privilégio de novos caminhos distantes da região da futura São Luiz do Paraitinga devemos destacar a importância deste "Caminho Novo" para a região que estamos estudando- caminho esse que faria não só uma ligação direta entre o interior da região das Minas Gerais e os principais portos mas também, à própria capital da Colônia. Afinal, mesmo causando um forte declínio inicial em determinados locais das antigas rotas, permitiu um grande avanço econômico para toda aquela região, de uma forma mais ampla. Inclusive, muitas pessoas que ascenderam economicamente e socialmente nas regiões privilegiadas pelas novas rotas comerciais puderam futuramente retornar e investir na região que hoje engloba a cidade de São Luiz do Paraitinga. Os documentos analisados por Jaelson Trindade comprovam que são vários os casos de famílias que conseguiram obter as sesmarias para povoar áreas em torno desse "Caminho Novo" no início do século XVIII e transformaram-se nos fundadores da maior parte das cidades "valeparaibanas", nas regiões vizinhas ao "Alto do Paraíba", décadas depois. Um exemplo é o próprio sargento Manoel Antônio de Carvalho. ${ }^{103}$

De qualquer forma, quanto à região privilegiada nessa dissertação, é fato um forte declínio da ocupação territorial, que era até então crescente antes do surgimento da nova rota comercial do ouro. Um ofício da Câmara de Lorena de

\footnotetext{
${ }^{101}$ Cabe lembrar que na maioria das vezes era utilizada a própria mão-de-obra escrava para desbravar estes caminhos, no início, dificultosos para as próprias cavalgaduras. Vide SOUZA, Marina de Mello e. Parati: a cidade e as festas. Rio de Janeiro: Editora UFRJ/ Editora Tempo Brasileiro, 1994. páginas 3335.

${ }_{102}$ Mafalda P. Zemella. O abastecimento da capitania das Minas Gerais no século XVIII, pg.120 apud SOUZA, Marina de Mello e. Parati: a cidade e as festas. Rio de Janeiro: Editora UFRJ/ Editora Tempo Brasileiro, 1994. páginas 33-35.

${ }^{103}$ DAESP, Sesmarias, vol IV, pág 20 e 47 e vol III, pág 60. apud TRINDADE, Jaelson, op cit, pág 1011.
} 
$1725^{104}$ relata a preocupação que começa a surgir no governo do Rio de Janeiro em povoar todo o trecho do "Caminho Novo", haja vista a locomoção de muitas pessoas então habitantes do "Alto Vale do Paraíba" integrando-se à nova rota comercial.

Praticamente relegada à penúria econômica e, quase desabitada - após aquela ocupação inicial que ocorreu durante todo o final do século XVII e todo o século XVIII - a região cercada pelo curso dos rios Paraitinga e Paraibuna não conseguiu levar a frente o processo de ocupação inicial e teve que aguardar o advento do café para alcançar um progresso econômico e populacional mais efetivo. Mas, aí, já estamos bem a frente, nos meados do século XIX. ${ }^{105}$

Não foi possível pela documentação encontrada até agora identificar as famílias que povoaram a região do rio Paraitinga no momento da circulação do ouro pela região, momento, aliás, que estamos considerando como o início da ocupação do território luizense e que veremos ser referencial também para a constituição de diversas manifestações da cultura popular local. O que se sabe mais certamente é que as sesmarias que tinham sido concedidas pelo capitão-mor de Taubaté Felipe Carneiro de Alçouva e Sousa ao capitão Mateus Vieira da Cunha e a João Sobrinho de Moraes em 05 de março de 1688 e que compreendiam toda a região da atual cidade de São Luiz do Paraitinga, são praticamente abandonadas pelos seus receptores, frustrando-se a primeira tentativa de povoamento, como apresentado, com a abertura do "Caminho Novo" do ouro. ${ }^{106}$

Há, na verdade, uma versão diversa sobre a concessão da primeira sesmaria da região - da atual cidade de São Luiz do Paraitinga - embora esta não modifique em nada a realidade do abandono da proposta de povoação inicial. Essa informação aventada por Marcelo Toledo recuaria a história local ao tempo das "bandeiras", anterior às tropas. O sertanista Vieira da Cunha teria partido de Taubaté em sua

\footnotetext{
104 DAESP, Ofícios da Câmara de Lorena, Guaratinguetá, etc, cx. 06, ord. 232, docs 6-1-18, 6-1-22, 6-124 (anos 1725-1726); DI, vol. L., pág. 157, 160, 168, 171, 245, 264 e 267 apud TRINDADE, Jaelson op cit.

${ }^{105}$ Carlos Murilo Santos - op cit - busca respaldo na obra de Lemos, Antonio Carlos. Casa Paulista. São Paulo: Edusp, 1999 reafirmando que a composição do vale do Paraíba paulista, antes da chegada do café, não passava de fazendas pequenas cuja função econômica era restrita à subsistência e abastecimento das tropas que por ali transitavam. Não havia, segundo ele, atração econômica alguma para se habitar a região, fazendo jus aos incentivos do poder régio.

106 TRINDADE, Jaelson Bitran. No caminho do Paraitinga in São Luiz do Paraitinga - Publicação $n^{\circ} 02$ - Conselho de Defesa do Patrimônio Histórico Arqueológico, Artístico e Turístico do Estado Condephaat. Secretaria da Cultura, Ciência e Tecnologia do Governo do Estado de São Paulo, 1977.
} 
missão bandeirante, estabelecendo um arraial com o nome de Santo Antônio e São Luiz do Paraitinga. ${ }^{107}$

Fica já estabelecida, entretanto, e como há pouco anunciado, uma marca fundamental do período inicial da ocupação: a "cultura das tropas". Toda a região acabou tendo abrigado o sistema de tropas, não apenas circunscritamente o território atual de São Luiz do Paraitinga, onde suas marcas são sim mais fortemente percebidas. Encontramos também as mais diversas formas de manifestação da cultura popular de todo o vale do Paraíba que se ligam a esta "cultura tropeira" de então.

Desta forma é muito importante fortalecer a argumentação de que embora a fundação de um povoamento luizense só tenha se efetivado às vésperas do século XVIII, e a ocupação populacional mais consistente só ocorreu em fins do século XIX, é necessário retroceder à atmosfera das primeiras tentativas de ocupação desse território, enxergando a força da tradição destes grupos "carguereiros". A permanência de muitos elementos típicos das tropas da época do início da ocupação permite um grande número de comparações ao nos deparamos com manifestações como as dos grupos de folia presentes nas festas do Divino, com destaque para a sua estrutura de locomoção, semelhante às das tropas de então. E são muitos os exemplos que poderiam ser dados neste sentido.

Até o fim do séc. XIX, quando as ferrovias são construídas, ${ }^{108}$ era o comércio de tropas o preponderante na maior parte do país. Ainda mais na região do Vale do Paraíba, pela sua vocação de escoamento da produção devido à proximidade do litoral, percebemos a importância do sistema de transporte em tropas. Além da fundamental questão econômica, fica marcada, de forma ainda mais forte para nossa discussão, a contrapartida cultural que essa situação toda proporcionou principalmente pela "cultura tropeira". Relatos como o do folclorista Câmara Cascudo são exemplos comprobatórios disso embora carreguem um juízo de valor

\footnotetext{
107 ARAUJO, Alceu Maynard. Alguns ritos mágicos: abusões, feitiçaria e medicina popular In Separata da Revista do Arquivo do Estado de São Paulo, 1958. Referência já apresentada por TOLEDO, Marcelo Henrique Santos, op cit, pág 73.

108 As ferrovias começaram a ser instaladas na região do Estado de São Paulo a partir de 1875, fazendo definhar o modo de transporte tropeiro. Um trabalho importante que trata desta realidade chama-se $D e$ tropas, trilhos e tatus: arredores paulistanos do auge das tropas de muares à instalação das estradas de ferro de autoria de Silvia Queiroz Ferreira Barreto Lins, tese de doutoramento apresentado ao programa de história social da Universidade de São Paulo, 2003.
} 
preconceituoso $^{109}$ como na qualificação de superstições e crendices para os atos provavelmente religiosos desta população. É com essa visão de superstições e crendices que precisamos tomar distância:

"Era enorme o movimento de tropas, de pousos e ranchos a cada jornada, fazendo florescer o comércio de beira de estrada, originando povoados, freguesias, vilas, cidades. A atividade ao longo do caminho das tropas influenciou profundamente o comportamento de suas populações, refletindo na maneira de se vestir, nos tipos de comida, no artesanato em couro e em vime, na literatura oral, bem como nas suas superstições e crendices." 10

No capítulo seguinte tratarei com mais detalhes dos grupos de folia do Divino e veremos várias características que permaneceram desta tradição das tropas na peregrinação que fazem os grupos de folia nas festas atuais. Adiantando alguns exemplos, a tradição de literatura oral é uma das presenças marcantes na história da comunicação das tropas e, como de se imaginar, constitui ainda a base para a formação de todos os cantos das folias na atualidade. Características típicas do mundo popular, como a grande capacidade de improvisação e adaptação às dificuldades, também se mantém vigentes.

Toda tropa tradicionalmente trazia à sua frente uma "madrinha" - nome dado ao animal que comandava a tropa. Por sinal, um animal sempre muito bem ornamentado, com destaque a um sino pendurado no pescoço. Por coincidência ou não, a cor vermelha - cor marcante nas festas do Divino - predominava sempre nestes adornos. Um destaque muito semelhante ao papel representado pelo cavalo do festeiro, que abre ainda hoje, de maneira muito simbólica, o "comboio" da folia do Divino.

Mantém-se também a tradição das cangalhas para carregar os suprimentos da folia - como das tropas - agora com a função adicional de carregar as prendas arrecadas na peregrinação em nome do Espírito Santo. Chamado de carguereiro da folia, o sujeito que exerce essa função desempenha um trabalho idêntico ao realizado por determinados participantes das tropas.

\footnotetext{
109 Tomando cuidado em não ser anacrônico lembrando ser típico do início do século XX um forte preconceito com manifestações advindas do "mundo do popular".

${ }^{110}$ CASCUDO, Luís da Câmara. Dicionário do folclore brasileiro. 10a edição, São Paulo: Global 2001, páginas 699-670.
} 
Considero ainda mais fundamental nessas similaridades a dinâmica de um modo de vida que se manteve, obviamente adaptando-se às novas situações. Todo grupo de folia, como qualquer grupo carguereiro, mantém sua sobrevivência durante a peregrinação através das trocas materiais e de experiências de uma forma mais ampla. $\mathrm{O}$ auxílio vem de pessoas desconhecidas, mas que partilham signos similares, permitindo uma relação como a de pessoas conhecidas há muito tempo. Os tradicionais "pousos" de folia, onde o sagrado e profano se misturam de uma forma ainda mais intensa - por exemplo, nos diversos bailes e jantares oferecidos após celebrações religiosas-, remetem-nos a este tempo anterior à própria fundação do município luizense.

\section{2 - A fundação de uma nova cidade.}

Mesmo alijado dos principais corredores econômicos da colônia em fins do século XVIII o vale do Paraíba é alvo das novas medidas de controle do governo régio. Portugal apresentava muitas dificuldades em controlar o imenso território brasileiro e passa a pôr em prática, definitivamente, uma política adequada justamente a este fim.

Data de $1765^{111}$ a nomeação de um novo governador da Capitania de São Paulo que deveria imprimir, com todo o cuidado, as novas instruções administrativas advindas, sobretudo, do então Primeiro Ministro Real: Marquês de Pombal. Foi este célebre ministro que nomeou Morgado de Matheus - Luiz Antônio de Souza Botelho Mourão - como o novo Governador da Capitania de São Paulo, e visava a um controle estrito sobre a economia e a política de toda a colônia em um forte processo de centralização e controle.

Abaixo, cito um dos despachos do Morgado de Mateus, exemplificador desta proposta que acabou vingando na fundação da cidade luizense:

“ desejando S.M. consolidar os domínios de suas capitanias do Brasil pelos meios mais próprios, não só quanto ao estabelecimento de sua economia interior, mais ainda quanto à conservação e defensa deles, determinou que nos

\footnotetext{
${ }^{111}$ TOLEDO, Marcelo Henrique. Op cit, pág 9, 2001.
} 
lugares mais próprios nos Sertões, e fronteiras deste Estado se fundassem Vilas, Aldeias, que aumentassem a povoação e a defesa" ${ }^{\prime 12}$

Uma das cidades da região valeparaibana mais importantes nessa época era a que compreendia a Sesmaria de Guaratinguetá. Seu papel de entreposto no escoamento da produção de toda a região fazia com que fosse mais habitada e desenvolvida, e que as suas autoridades recebessem mais atenção naquela constante disputa pelo poder entre os novos povoamentos que iam sendo estabelecidos e que necessitavam o aval das autoridades portuguesas. $\mathrm{O}$ então juiz das Medições e Sesmarias de Guaratinguetá, também sargento-mór, Manuel Antônio de Carvalho, encaminha em 1768 um requerimento para a fundação de um novo povoamento entre Taubaté e Ubatuba e que se chamaria São Luiz e Santo Antonio do Paraitinga. ${ }^{113}$

Era a consolidação jurídica que proporcionaria o surgimento de uma população fixa naquela região, tão importante para o deslocamento do ouro em suas fases iniciais, e frustrada na ocupação populacional após o deslocamento da rota desse mesmo produto. Agora, a Capitania crescia, as necessidades de desbravar novos territórios aumentavam e a região cortada pelo rio Paraitinga mantinha sua importância estratégica devido a proximidade com o litoral em um território de tão difícil penetração.

Talvez o documento mais remoto da cidade luizense preservado no Arquivo do Estado de São Paulo seja o dessa petição do sargento-mór Manuel Antonio de Carvalho ao Morgado de Matheus referente também ao povoamento de Paraibuna, em $1768^{114}$ :

" requerimentos que lhe tem feito muitos moradores destas villas, e alguns da Capitania de Minas, sempre diguinissimas petições para novos povoados (...) como para esta povoassam entre o rio chamado Paraitinga, e, Paraibuna, a qual a povoassam queriam fazer e estabelecer raízes gozando Tão, somente dos previlegios que Sua Majestade Concede haos novos povoadores

\footnotetext{
${ }^{112}$ MOURA, Américo Brasiliense A. de. Governo de Morgado de Matheus no vice Reinado do Conde da Cunha, in Revista do Arquivo Municipal de São Paulo, vol. LII, SP, 1938, pág 38 apud TRINDADE, J. op cit, pág 10.

113 Apresenta concomitantemente um requerimento para a fundação do povoamento que deu origem à atual cidade de Paraibuna, obtendo sucesso em ambos. Chama a atenção a manutenção do nome - São Luiz e Santo Antonio de Paraitinga - dado possivelmente pelo sertanista Vieira da Cunha tempos atrás.

${ }^{114}$ A data exata deste requerimento encontra-se ilegível, com exceção do ano de 1768. Entretanto, ele está arquivado anexo à resposta deste requerimento pelo Morgado de Matheus, datada de 02 de maio de 1769.
} 
da nova povoassam; e assim quer mais o Suplicante que V. Exa. Seja servido Conceder-lhe a dita faculdade para levantar, a povoassam, e a tombar, duas Leguas de terras em quadra para acomodação da pobresa, que não podem tirar da Sesmaria e as mais serem dadas aos povoadores a Cada hum, as que lhes forem necessárias, as suas famílias na forma que V. Exa. Determinar..."115

No caso de São Luiz do Paraitinga, o requerimento é aprovado no ano seguinte, mais especificamente no dia 02 de maio, pelo governador-geral D. Luis Antônio de Sousa Botelho e Mourão. No dia 08 de maio, nomeia-se Manoel Antonio de Carvalho fundador e governador da nova povoação e oficialmente "nasce" São Luiz do Paraitinga ${ }^{116}$. Reforçando sempre os limites desta idéia de fundação delegada a uma única pessoa - mais do que reconhecimento, é a cessão legitimada do poder a uma determinada pessoa sobre um grupo que precisa de controle burocrático sob o ponto de vista da administração colonial. Dessa forma, não podemos perder de vista que a data de 08 de maio de 1769 é apenas uma baliza adotada oficialmente para a fundação desta cidade, prova é toda nossa discussão anterior das diversas tentativas de ocupação precedentes a este momento histórico.

De qualquer forma marca-se aí o início da "história oficial" de São Luiz do Paraitinga. Como era de praxe na sociedade do século XVIII e, servindo para reforçar o papel da religiosidade nesses municípios nascentes, encontramos no documento oficial da fundação do povoado o incentivo primordial à construção de uma Igreja, com a invocação de Nossa Senhora dos Prazeres. ${ }^{117}$

Dentro da proposta de um maior controle da sociedade, a questão religiosa era uma das principais. Construir imediatamente uma Igreja era um signo importante do controle estabelecido. Ainda mais quando a religiosidade estava pautada em práticas tradicionais.

Citando o cientista religioso Riolando Azzi, Augustin Wernet descreve a implantação de um catolicismo tradicional com caráter leigo, social e familiar, paralelo à própria colonização portuguesa em todo nosso país. ${ }^{118}$ Somente em

\footnotetext{
${ }^{115}$ Departamento do Arquivo do Estado de São Paulo, Ofícios das Câmaras 1721-1822, caixa número 7, São Luiz do Paraitinga, ordenação 233, pasta 3.

116 PETRONE, Pasquale.op cit, página 313 referindo-se a pesquisas de Adolfo Augusto Pinto. A Provincia de São Paulo, 1888, página 504.

${ }^{117}$ Chama muito a atenção o desaparecimento de Nossa Senhora dos Prazeres na história religiosa local. Hoje São Luiz de Tolosa é o padroeiro oficial e não há explicação clara, segundo o próprio clero local, da supressão desta santa como símbolo religioso local.

${ }^{11}$ WERNET, Augustin. A Igreja Paulista no século XIX - a reforma de D. Antônio Joaquim de Melo (1851-1861). São Paulo, Editora Ática, 1987.
} 
meados do século XIX teríamos contato com as iniciativas da corrente ultramontana buscando então uma postura muito mais individual, clerical e tridentina ${ }^{119}$. A descrição desse autor do catolicismo que imperava em nosso país, classificado como "catolicismo tradicional", condiz muito com as características encontradas em praticamente todas as referências religiosas dos primeiros tempos de São Luiz do Paraitinga, reforçando um aspecto sempre presente na sua história e até paradoxal: a interligação entre o poder religioso e político concomitante a uma grande liberdade de expressão das práticas religiosas. De acordo com o que diz Wernet:

“ Fé e cultura caminharam de mãos dadas, numa inter-relação tão íntima que não poucas vezes era difícil distinguir o elemento cultural do religioso. A Igreja no Brasil se apresenta, desta maneira, como 'cristandade', estado de interpenetração estreita entre 'religião' e 'sociedade', 'Igreja' e 'Estado', sagrado e profano, em que o poder político e o religioso se confundem, sendo que a supremacia pode pertencer ao religioso ou ao político",120

Basta escutar mais uma vez a voz de uma personagem tão importante na cidade como D. Cinira para imaginarmos a força desta relação:

"Aqui em São Luiz do Paraitinga, o padre manda até hoje mais que o prefeito. São tantas histórias de antigamente em que a prefeitura tinha que mudar o que ia fazer só pelo motivo do padre tinha opinião diferente (...). Agora, da época de antigamente que nem se fala... a voz de quem representava a religião, que nem padre tinha, era a que mandava. E não precisava ser gente ligado a Igreja não, aquela pessoa da comunidade mesmo, inventava lá umas regras e ai de quem não seguisse, até discriminado era. (...) O povo podia estar numa roda de jongo, onde se mistura um monte de coisa, aquilo era a religião e nenhuma outra coisa na cidade poderia atrapalhar." 121

Sua fala faz ascender este papel da religiosidade exercida sob padrões tradicionais, longe de qualquer forma de controle oficial. Veremos o quanto isso é forte na história de São Luiz do Paraitinga dentro da festa do Divino, em que atos como as doações de prendas e realizações de promessas são feitos a partir de uma concepção de relação direta com o sagrado. Nessas formas suprimem-se muito rituais e relações estabelecidos pela Igreja Católica dentro de sua intenção de um

\footnotetext{
119 Nos capítulos seguintes mostrarei muitos exemplos representativos da dificuldade de afirmação desta linha mais rígida da Igreja. Nas festas do Divino atuais são inúmeras as situações de conflito entre clero e povo justamente por essa miscigenação de práticas ditas "profanas" e "religiosas" no dia-a-dia da população.

${ }_{120}^{120}$ WERNET, Augustin, op cit, pág 18.

${ }^{121}$ Entrevista com D. Cinira realizada em setembro de 2006.
} 
maior controle da religiosidade, em atos como doações de prenda e pedidos à bandeira do Divino. Neles não há uma necessidade da presença de um agente eclesiástico.

Naturalmente, a intenção de controle sempre existiu e a dificuldade de se alcançar este objetivo acaba por obrigar a própria Igreja a ceder, dando passagem a diversos atos contrários à sua rígida atuação dogmática, prezando mais o convívio "pacífico" com as manifestações populares de religiosidade.

Quanto à atitude da administração colonial portuguesa de priorizar a construção de uma Igreja logo na fundação de São Luiz do Paraitinga, mostra, acima de tudo, a necessidade de fixar símbolos do poderio administrativo. Confirma-se, juntamente, essa ligação íntima entre poder político e religioso.

Junto da construção da Igreja, construir uma casa para a Justiça, Casa da Câmara, Cadeia, Pelourinho eram os anseios presentes nas correspondências oficiais de Manuel Antonio de Carvalho, visando a uma organização daquela povoação já considerada como vila a partir de 31 de março de 1773. Abaixo, cito um trecho dessa correspondência clamante da necessidade desta casa de justiça:

"Anno do Nascimento de Nosso Senhor Jesus Christo de mil e setecentos e setenta e tres annos aos trinta e hum dias do Mes de Marso do dito anno nesta Nova povoassam de Sam Luis e Santo Antonio de Paraitinga aonde estava presente o administrador e fundador dela Manoel Antonio de Carvalho Commigo Escrivam ao diante nomeado (...) que ali se pertendia formar Villa para se poder administrar a Justissa aqueles Povoadores por ficarem muito distantes das Villas sircumvezinhas a que heram e tinho sido athé tempo subgeitos a qual fundasam se fazia para aumento e perpethuidade daquele lugar para prova de que já se achava hua Igreja acabada e com todos paramentos para nela se poder selebrar". ${ }^{122}$

Entretanto, a Igreja em homenagem à Nossa Senhora dos Prazeres construída - de forma extremamente simples e hoje desaparecida - foi um dos únicos edifícios construídos rapidamente, o que mostra a dificuldade de povoamento enfrentada por Manoel Antonio de Carvalho e, naturalmente, pela administração colonial na nova cidade valeparaibana. Aliás, sabemos o quanto esta situação está longe de ser uma exclusividade da história luizense: em todo o país, o governo régio enfrentava imens as dificuldades de administração.

\footnotetext{
${ }^{122}$ Departamento do Arquivo do Estado de São Paulo, Ofícios das Camaras/ São Luiz do Paraitinga, cx 7 , ord. 233, doc 7-3-24.
} 
De qualquer forma, podemos apontar como complicador específico dessa situação, a constante instabilidade política luizense. Em grande parte isto era fruto da frustração daquele projeto povoador extremamente apoiado pelas instâncias superiores em sua proposição. Encontramos vários exemplos da troca dos comandantes políticos, aparentemente pela dificuldade mesmo de conseguir imprimir uma política de ocupação de um território paupérrimo.

Em 1791, o fundador Manuel Antonio de Carvalho é substituído por um grupo totalmente heterogêneo chefiado pelo Tenente de Cavalaria José Gomes de Gouveia e Silva, parecendo só piorar a incipiente estabilidade política local. Disputas de poder afloram ainda mais, envolvendo outras esferas, quando o juiz Pascoal Roiz Veloso pede para que a procissão de Corpus Christi de 23 de maio de 1799 não saia da Câmara Municipal, referindo-se a esta como uma "casa de presença de homens poderosos, senhores de terras" em tom altamente negativo. ${ }^{123}$ A impressão que se tem é de um ambiente de conflito entre moradores e chefes locais, em grande parte graças à difícil realidade econômica vivida pelas famílias.

Pensando pelo lado "oposto da moeda", podemos até considerar como sendo grande a contribuição dessa dificuldade administrativa para o fortalecimento do modo de vida popular, pautado muito mais na coletividade, na interação cultural e na espontaneidade de seus membros, claramente constituinte da marca fundamental da identidade luizense que buscamos explorar.

Foi só com o advento do café e uma nova leva de migração para o vale do Paraíba - já em meados do século XIX - que veremos São Luiz do Paraitinga receber toda estrutura governamental ansiada desde a época de sua fundação, mas, insuficiente até então. A marca da ocupação inicial era o povoamento do território por núcleos familiares, portando uma atividade econômica restrita à agricultura de subsistência e com poucos vínculos comerciais. Era, portanto, uma realidade marcadamente pobre.

Marcelo Toledo é bastante enfático sobre este momento:

“O quadro econômico permaneceu restrito, auto-suficiente e pobre, o que não poderia justificar maior desenvolvimento do núcleo. Permaneceu 'Vila Medíocre'."124

\footnotetext{
123 ALMEIDA, Jaime. Foliões. op cit. Pág 30.

124 TOLEDO, Marcelo Henrique Santos, op cit pg 10 baseado na obra de PETRONE, Pasquale, op cit página 280.
} 
Da situação do primeiro recenseamento de São Luiz do Paraitinga, em 1774, auferimos a tônica do município que marcará seus primeiros cem anos de existência oficial:

“ famílias pequenas, com seu chefe, vivendo do trabalho próprio e dos membros da família, sem escravos, gente realmente miserável (...) Para o pouco mais de 800 pessoas que apresenta essa primeira contagem, há um número irrisório de proprietários (sete) cujo lote de escravos vai de 6 a 24 peças." "125

Para que se alcançasse um aumento real da ocupação populacional no município, uma maior produção econômica, além daquele caráter de subsistência, e a constituição de um centro urbano maior - com suas edificações vultuosas marcantes do patrimônio histórico que São Luiz do Paraitinga ostenta ainda hoje - é preciso passar à época da elevação à categoria de cidade. Ato consumado por lei provincial em 30 de abril de 1857 e coincidente com o auge da produção cafeeira no vale do Paraíba paulista. ${ }^{126}$

Acabamos assim dando um verdadeiro salto na história política de São Luiz do Paraitinga, contudo, nunca esquecendo a importância desse período inicial na constituição da identidade de uma cidade cujo protagonismo está no mundo do popular. Dificuldades econômicas e políticas não são suficientes para diminuir a importância das constantes referências às organizações de festas - com destaque para as do Divino - o que pode ser percebido por pedidos de licença para a Câmara local já no período inicial de constituição do povoamento. Disputas por espaços melhores, pedidos de licenças de peregrinações de folias, divergências e convergências entre os líderes de grupos folclóricos, são alguns dos exemplos que nunca deixamos de encontrar na escassa, mas, reveladora documentação existente sobre esse período. Fica assim, desde já, apontada uma forte vocação cultural como uma marca fundamental da história luizense refletida em documentos oficiais. Desde seus primórdios...

\footnotetext{
125 Departamento do Arquivo de São Paulo. População/ São Luiz do Paraitinga, cx 158, ord 158, ano 1774. Apud TRINDADE, Jaelson, op cit. Pág 312.

${ }^{126}$ Muller, Marechal D. P. citado por PETRONE, Pasquale, op cit página 310.
} 


\section{3 - Um "novo tempo": o desenvolvimento das lavouras cafeeiras no vale do}

\section{Paraíba.}

A administração da região do vale do Paraíba começa a sofrer uma profunda transformação no decorrer do século XIX com o avanço, cada vez maior, do protagonismo dos senhores escravocratas. Beneficiados pelo desenvolvimento da produção agrícola, sobretudo o surgimento da cultura cafeeira - mas também pelo avanço econômico de outras produções como a do açúcar - conseguem ir minando aos poucos o poderio exercido pela estrutura militar dominante na Capitania. ${ }^{127}$

Em São Luiz do Paraitinga, a nomeação de José Lopes Figueira, em 1827 para o posto de capitão-mór da vila, havia demonstrado justamente esta mudança do poderio político local ${ }^{128}$. Representando os anseios de uma elite agrária em formação - foi oficializado no dia 30 de julho nesse cargo devido à vacância pela morte do Cap. Mor José Gomes - no dia 02 de agosto já encaminha ofício apoiado pelos políticos de Ubatuba, pregando a necessidade de melhorias na estrada que cortava o município luizense rumo ao porto deste município vizinho. Pedia a:

“conservação daquela estrada, pois que além de cooperar para o aumento do Comércio desta vila e vizinhas, ainda nos provém daquele Porto os socorros precisos". ${ }^{129}$

Estávamos na década de 20 do século XIX, justamente a data da implantação do cultivo do café no vale do Paraíba e de proeminência desta nova elite ligada à produção agrária na sociedade de então. As tentativas da implantação das lavouras de açúcar, aliás, foram rapidamente substituídas pela atração do preço do café em elevação no mercado internacional, abrindo-se um novo e, muito rentável por sinal,

\footnotetext{
${ }^{127}$ Esta realidade irá, no decorrer do século XIX, minar o importante poder exercido pelos capitães-gerais na sociedade, observando-se rapidamente uma ascensão, principalmente, na região do vale do Paraíba, dos grandes fazendeiros aos cargos administrativos. Constituía-se assim uma nova elite no país, sobretudo cafeeira. Uma obra de referência para esse contexto é HOLANDA, Sérgio Buarque (org). História Geral da Civilização Brasileira. Difusão Européia do Livro, São Paulo, 1967, Tomo 2, $2^{\circ}$ volume.

${ }^{128}$ Departamento do Arquivo de São Paulo. Ofícios diversos/ São Luiz do Paraitinga, ex 470. ord. 1265, Pasta Cap-Mor, oficio de 30 de julho de 1827.

${ }^{129}$ Idem anterior, ofício de 02 de agosto de 1827.
} 
campo de atuação: "fazia-se outrora muito açúcar, mas desde que subiu o preço do café desinteressaram-se os lavradores de cana para cuidar dos cafezais". 130

Essa ascensão foi proporcionada conjuntamente a um conglomerado de fatores adicionais ao surgimento do café - e que o fortalece ainda mais - neste momento histórico: uma verdadeira necessidade do crescimento da atividade agrícola como forma de beneficia-se economicamente e ocupar os "novos" territórios definitivamente; a dificuldade crescente de lucratividade com a mineração, por sinal, cada vez mais decadente; e a consolidação da produção de aguardente nesta região. De qualquer forma, e seguindo Caio Prado Jr. ${ }^{131}$, o café era, por si só um dos fatores causadores do fortalecimento econômico e social das regiões que passassem a produzi-lo. Era um dos produtos que mais ganhava importância nos mercados internacionais - isso já no século XVIII -, sendo natural que, no Brasil, assim como na maioria das colônias da América e da Ásia, fosse incentivada sua produção.

Coincidentemente, nas primeiras décadas do século XIX, os Estados Unidos ascendiam economicamente e assim sendo, abria-se um novo e importante caminho para o crescimento econômico do Brasil, especialmente para a Capitania de São Paulo e para a região de São Luiz do Paraitinga. ${ }^{132}$ Esse país se tornou um grande importador do café brasileiro e as divisas proporcionadas por este comércio - que crescera rapidamente - voltavam de alguma forma à região produtora, fortalecendo politicamente os fazendeiros locais. E não eram apenas os EUA o destino deste comércio em desenvolvimento ${ }^{133}$ :

“A expansão dos cafezais no vale do Paraíba, nos albores de nossa vida independente, deu um impulso novo à economia nacional e a produção cafeeira, em particular. Os anos da década de 1830 foram decisivos: nesse período tornou-se o Brasil o primeiro produtor mundial de café; no ano de 1832 o café ocupou o primeiro lugar na pauta de nossas exportações e já no

\footnotetext{
${ }^{130}$ SAINT-HILAIRE. A viagem à província de São Paulo. São Paulo: Edusp. Belo Horizonte: Itatiaia, 1976.

${ }^{131}$ PRADO Jr, Caio. História Econômica do Brasil. 43ª edição - São Paulo: Brasiliense, 1998.

132 Discutirei à frente no trabalho que o benefício que a cidade de São Luiz do Paraitinga teve neste momento histórico foi mais pela configuração de um local de "entreposto comercial" do que de produtor de café propriamente. Além disso a riqueza do município estava concentrada nas mãos de algumas famílias poderosas em detrimento a uma falta de recursos generalizada para a maioria da população. De qualquer forma, é inegável a importância das transformações proporcionadas pela cultura do café na região valeparaibana de uma forma geral.

${ }^{133}$ Percebe-se pelas datas referenciadas na situação a seguir a importância da produção cafeeira nas décadas de 1830/40. Os impactos serão ainda mais fortes no vale do Paraíba paulista e fluminense, a maior região produtora deste cereal.
} 
ano de $1837 / 38$, esse valor, relativo ao café, alcançava $53,2 \%$, isto é, mais que a soma de todos os demais produtos exportados." ${ }^{34}$

A todo instante escutamos da população luizense a exaltação da riqueza do município proporcionada pela expansão da produção cafeeira. Analisando as construções históricas do município, é grande a predominância de obras datadas deste período. O núcleo urbano ia progredindo de maneira nunca vista antes e finalmente alcançam-se aqueles objetivos da época da implantação do povoamento: construção de uma imponente Igreja Matriz, prédios públicos como Cadeia e posteriormente, Grupo Escolar. Além de muitas obras particulares de vultuosas proporções para a realidade da época, possibilitando à cidade uma fisionomia muito próxima da que encontramos na atualidade, na região agora chamada de "centro histórico".

Um crescimento, aliás, mais do que suficiente, para o reconhecimento como já citado -, por lei provincial, datada de 1857, como cidade de São Luiz do Paraitinga. Segundo Marcelo Toledo, o controle político da cidade em seu período inicial de autonomia recai rapidamente sob o comando da família Domingues de Castro. Demonstrando esta íntima ligação com o poder econômico, o comando político vai justamente para a família, com a maior produção cafeeira naquele início da segunda metade do século XIX. ${ }^{135}$

Veremos no capítulo seguinte quão grande era o prestígio dos fazendeiros do café na organização das festas do Divino. Na maioria das vezes eram esses grandes fazendeiros que se revezavam no papel principal de festeiro. Constituíam-se disputas que mais do que a vocação religiosa demonstravam a disputa pelo prestígio e status social na comunidade.

A declaração do atual representante máximo da Igreja no município, Monsenhor Tarcísio, 94 anos, reflete esta imagem da preponderância da época do cultivo do café como o redentor da história local:

" Todo mundo sabe que a grande maioria das festas do Divino de grande tamanho na história da cidade foram organizadas pelos grandes fazendeiros do café. Era a época das riquezas da cidade, do grande desenvolvimento. Eles tinham muito poder e consequentemente conseguiam organizar festas maravilhosas. A Igreja era muito beneficiada também por

\footnotetext{
134 VALVERDE, Orlando. Estudos de Geografia Agrária Brasileira. Editora Vozes, Petrópolis, 1985.

135 TOLEDO, Marcelo Henrique Santos de. Op cit, pág 11.
} 
aquela riqueza, grandes festas, muita distribuição de comida, o povo realmente participando das festas... Porque o povo é o mais importante da festa, mas sem apoio, sem incentivo não consegue nada." ${ }^{136}$

Mesmo sabendo dos limites desta declaração, principalmente sobre a participação popular, se confirma a incorporação de um período áureo da história do município na memória de seus habitantes. Quanto à declaração do Monsenhor, fica difícil imaginar que tanto escravos quanto a população mais simples de uma forma geral encontrassem um ambiente tão propício para se manifestar. E que este poderio proporcionado pela bonança econômica realmente atingisse o grosso da população. Entretanto, esta imagem de um período mais próspero entra de maneira marcante na memória coletiva dos luizenses.

Um fato importante para a consolidação desse momento histórico como de destaque na identidade do luizense foi o recebimento da denominação de "cidade Imperial" título concedido por Dom Pedro II, em 11 de junho de $1873 .{ }^{137}$ Alcançava a cidade o auge de sua importância econômica e, conjuntamente, se fortalecia a construção de um contexto marcante para uma futura identidade assentada na valorização de um passado áureo e próspero - mesmo a história mostrando que não tenha sido bem assim - sob o ponto de vista das dificuldades de protagonismo econômico de cidades como São Luiz do Paraitinga no mundo atual.

Como citado no capítulo anterior, se a realidade econômica vem alijando municípios pequenos como São Luiz do Paraitinga da ocupação dos principais espaços de atuação haja vista os avanços tecnológicos e econômicos de uma forma mais ampla, é importantíssimo para a população se perceber como pertencente a uma localidade que fora, pelo menos, de destaque para a economia do país no decorrer de sua história. Fazer parte de um grupo folclórico, além de ter um caráter religioso imprescindível, permite àquele cidadão comum participar mais ativamente de uma "história de sucesso". Afinal, é um legitimo representante de uma cidade com uma história "respeitável" como diz a luizense Cinira dos Santos:

\footnotetext{
136 Entrevista com Monsenhor Tarcísio de Castro Moura, em março de 2007. Este padre é uma destas figuras fundamentais no dia-a-dia da comunidade luizense. Hoje, pároco aposentado, com 94 anos - 68 de sacerdócio -, comandou a Igreja local por mais de quarenta anos e é um dos principais defensores da manutenção das manifestações populares nas festas locais. Constantes discordâncias da comunidade com os párocos mais jovens, encontram no Monsenhor Tarcísio uma espécie de "juiz" para a solução dos problemas.

${ }^{137}$ PINTO, Adolfo Augusto citado por PETRONE, Pasquale, op cit página 315.
} 
“ Numa época em que nem a praça existia ainda em São Luiz do Paraitinga, já corria a "cavalhada" nas festas do Divino. (...) E era uma época muito rica, pois São Luiz possuía os barões do café! Era considerada a terceira economia do Estado, a "renda per capita" da população era muito grande para a época e até nosso imperador Dom Pedro II passou por aqui. Certa vez, Dom Pedro estava indo para Ubatuba e pernoitou em uma fazenda, aqui, de São Luiz. Na beira da estrada, ao tomar conhecimento de todas nossas coisas, deixou um diploma para São Luiz chamando de "imperial cidade". Pra se ter uma idéia, não sei se no estado do Rio de Janeiro há alguma cidade com este título, mas, aqui em São Paulo, é só São Luiz."138

A fala atual de Dona Cinira, mais uma vez, vem confirmar a importância atribuída a esse momento histórico de destaque da cidade. Como característica fundamental da oralidade, vemos em seu relato uma indefinição temporal, fazendo parecer com que a passagem de Dom Pedro II pela cidade tenha sido muito próxima de sua vivência. A citação da cidade como terceira economia do estado e, ainda de forma mais interessante, a classificação de "renda per capita" muito alta dos habitantes não se encontra amparada em qualquer documentação oficial, entretanto, é fundamental para esta "invenção da tradição"139 de um passado rico luizense.

Falo em invenção, pois, mesmo admitindo ser esse o momento histórico de maior importância econômica do município e, possivelmente, das próprias festas do Divino, torna-se necessário apresentar alguns dados que limitam essa preponderância do café e da riqueza da cidade, passando uma imagem de prosperidade. Não deve ser nenhuma grande novidade afirmar que essa riqueza, ainda venerada pela população luizense, pertencia a pouquíssimos grandes fazendeiros, frente a uma população, na sua maioria, paupérrima. E que esses próprios fazendeiros não detinham um grande poderio quando comparados inclusive a pares de municípios vizinhos.

Mais uma vez apontando a relatividade da importância de São Luiz do Paraitinga, é importante entender que a cidade era um entreposto comercial de uma produção cafeeira vultuosa, tendo-se beneficiado dela. É fato o desenvolvimento da cidade nesse período; e eu mesmo reafirmei há pouco a importância desse momento histórico para a configuração de todo o patrimônio material local.

\footnotetext{
${ }^{138}$ Entrevista com Dona Cinira dos Santos, op cit.

${ }^{139}$ Termo de Eric Hobsbawn discutido no primeiro capítulo.
} 
Se as pesquisas históricas não confirmam o valor amplo desta suposta riqueza, não se pode desconsiderar a importância da construção coletiva de um passado luizense muito rico. Considero-a um fator primordial para o fortalecimento de identidades fortes, presentes na cultura local, e que sempre estamos ressaltando na análise aqui empreendida. Gostaria apenas de demonstrar, com essa situação específica da economia luizense, um elemento que diz respeito à cultura popular de uma forma mais ampla: o quanto elementos cruciais para a sobrevivência do espaço do popular - como esta construção do passado rico luizense - são muito mais invenções do que fatos amparados na realidade.

Muito diferente de algo depreciativo dessa cultura, a dita invenção é a própria confirmação da dinâmica desse mundo específico. A riqueza de buscar mecanismos, os mais diversos possíveis, para se fortalecer e vencer os desafios que sempre se apresentam, é um dos grandes trunfos da cultura popular. São essas situações as responsáveis pela sua constante transformação e, até mesmo, pela sua perpetuação neste mundo cada vez mais individualizado e homogêneo. A decadência da produção do café da região valeparaibana no início do século XX constituirá um golpe duríssimo na economia da região, atingindo o dia-a-dia de toda a população. Dificuldades de diversas naturezas estarão sobrepostas: econômicas, sociais, políticas. Sendo, contudo, insuficientes para enfraquecer a maioria das manifestações populares.

\section{4 - A “invenção” do poderio cafeeiro luizense}

Como já afirmado, é inegável a importância exercida pela produção cafeeira sobre a história da cidade. Em qualquer apresentação sobre São Luiz do Paraitinga, é um passo imprescindível discorrer sobre a riqueza deixada pelo café e a importância deste na construção identitária do luizense. Torna-se, entretanto, muito interessante perceber os limites da riqueza e a restrição dos números da produção cafeeira autóctone.

São Luiz do Paraitinga vai, sim, aproveitar esse momento privilegiado da economia de todo o vale do Paraíba, servindo como um entreposto fundamental para o escoamento da produção cafeeira. Uma economia em expansão, proporcionada 
pela exportação do café, inegavelmente beneficiará diversos grupos ${ }^{140}$, ainda mais se localizados justamente em um dos principais corredores dessa produção.

Carlos Murilo considera a cultura cafeeira como definidora de uma unidade espacial mais clara para o próprio vale do Paraíba sendo, a partir de então, fundamental para a unidade da região. ${ }^{141}$ Do outro lado da moeda encontramos os indícios que confirmam a tradição de desigualdade em uma das regiões mais exploradoras da mão-de-obra escrava neste momento histórico brasileiro, amparadas por um forte apoio do governo nacional. ${ }^{142}$

São Luiz do Paraitinga não constituiu uma das localidades onde o café fora implantado com tanto afinco já na sua chegada à região. Com grande diversificação de sua produção econômica, e voltada acima de tudo ao mercado regional, a cidade não foi instigada a uma espécie de "surto cafeeiro" substitutivo, como na maioria das localidades. Até então a produção de açúcar era a dominante - inclusive nas cidades próximas como a vizinha Taubaté - e com sua queda, as lavouras eram simplesmente suplantadas pelas cafeeiras na maioria dos casos. Como já não era este o perfil da cidade, naturalmente não observamos esse movimento.

Para efeito de comparação, transcrevo abaixo uma tabela de produção do café em arrobas da Província de São Paulo do ano de $1836^{143}$, pesquisada por José Teixeira de Oliveira ${ }^{144}$ :

Tabela 01 - Produção cafeeira em arrobas de 1836 - vale do Paraíba

Bananal

Areias (incluindo São José do Barreiro)

Lorena

Guaratinguetá

Taubaté

Pindamonhangaba

Jacareí
64.822 arrobas

102.797 arrobas

33.649 arrobas

22.442 arrobas

23.607 arrobas

62.628 arrobas

54.004 arrobas

\footnotetext{
140 Acredito tornar-se desnecessário relembrar os limites desta riqueza, restrito a pequenos grupos intimamente ligados aos principais grupos de poder político da época. Afinal, nossa realidade nacional, infelizmente, não se alterou tanto até os dias atuais, haja vista os índices de desigualdades sociais exorbitantes.

${ }_{141}$ Muitos povoamentos, incluindo, o luizense, são elevados a categoria de cidades neste momento.

142 SANTOS, Carlos Murilo. Op cit, página 121.

${ }^{143}$ A produção total da província em 1836 foi de 558.136 arrobas e já constituía o produto mais exportado do país, correspondendo a mais de $50 \%$ de toda a exportação do país.

144 OLIVEIRA, J. T. História do Café no Brasil e no Mundo. Livraria Kosmos Editora LTDA, Rio de Janeiro, 1984, página 266
} 
Paraibuna

Mogi das Cruzes

Parnaíba

S. Carlos (atual Campinas)
23.322 arrobas

11.237 arrobas

55.000 arrobas

8.081 arrobas

Fonte: OLIVEIRA, J. T. História do Café no Brasil e no Mundo. Livraria Kosmos Editora LTDA, Rio de Janeiro, 1984.

Embora não tenha conseguido levantar o número da totalidade da produção luizense neste ano, fica evidente a modéstia numérica em comparação aos municípios limítrofes. Jaelson Trindade aponta a existência de três fazendas dedicadas à produção cafeeira em maior escala neste município, concomitante a uma tônica de policultura ${ }^{145}$. Uma delas, provavelmente, seria da família "Castro", haja vista seu domínio na produção cafeeira desde meados do século XIX, em São Luiz. No censo de $1830^{146}$, consta como produção desta família “cerca de 200 arroubas de café, 1000 alqs. de milho, 60 feijao e 8 arros"147. No restante da população pesquisada, é praticamente insignificante a produção cafeeira. No entanto, há grande destaque para produção de milho, feijão, dando jus muito mais à caracterização de "Celeiro do Vale"148 do que grande produtora do café.

Carlos Borges Schimidt reforça esse papel alternativo de São Luiz do Paraitinga pelas necessidades decorrentes do grande número de tropas que passavam por aquela estrada, que considerava a segunda mais importante da então Província de São Paulo ${ }^{149}$ :

"Centenas e centenas de milhares de arrobas de café por ali transitaram. Anualmente, entre sessenta e setenta e oito mil animais, transportando mais de um milhão de arrobas de café passavam por São Luiz do Paraitinga". ${ }^{150}$

Fica assim marcado o papel econômico exercido pela cidade quando também falamos do período cafeeiro do vale do Paraíba: um entreposto comercial de evidência e um ponto de encontro de destaque da província paulista. A participação

\footnotetext{
145 TRINDADE, Jaelson, op cit pg 16.

146 Departamento do Arquivo do Estado de São Paulo População/ São Luiz do Paraitinga, cx 160, ord. 160, Censo de 1830; $1^{\circ}$ Cia, fogos $n^{\circ} 1,2$ e 121; e $3^{\text {a }}$ Cia. Fogos $n^{\circ} 324,335,336,337,393,397,399,410$, 421 e 423.

${ }^{147}$ Idem anterior, fogos 335,336 e 337.

148 Definição para a cidade de SANTOS, Toledo, op cit página 16.

149 A estrada Taubaté - São Luiz do Paraitinga - Ubatuba era um centro muito importante da passagem das tropas que conduziam tanto o café do Vale do Paraíba como o do sul de Minas Gerais rumando ao litoral.

${ }^{150}$ SCHMIDT, Carlos. A vida rural no Brasil - A área de Paraitinga, uma amostra representativa. op cit, pág 34-35.
} 
de habitantes de toda a região nas festas populares luizenses, inclusive, deve-se muito ao papel de ligação, sendo São Luiz uma espécie de "porto-seguro" devido ao seu posicionamento geográfico privilegiado. E isso fica ainda mais evidente no contato direto com a memória local:

" Meu vô já dizia que da época de meus parentes de antes dele, que nem sei dizer quem são, a cidade já tinha muitas festas e recebiam muito daqueles viajantes que passavam por aqui nos lombos dos burros para levar seus produtos pra vender serra abaixo. Era o momento de comemorar e de louvar os santos que eles acreditavam e tudo ficava mais fácil pois os grandes fazendeiros do café bancavam tudo, era a hora dos pretos dançarem e comemorarem (...) Você pode acreditar pois eu moro em Taubaté mais minha família sempre viveu por aqui, tenho até impressão que logo no início da cidade, quando minha família tinha origem militar"'151

Uma fala reveladora em diversos aspectos, pois mostra a importância das tropas - mesmo sabendo os limites de uma memória construída sobre um período tão distante -, na importância representada pela figura do barão do café, assim como o momento de exceção que a festa cria, proporcionando tanto inversões dos papéis sociais como um arrefecimento, mesmo que temporário, da imensa opressão à qual os populares estavam submetidos. ${ }^{152}$

Voltando à situação da produção cafeeira, em 1854, a região vizinha de São Luiz do Paraitinga tornava-se a mais importante na produção do café em toda a Província. Juntos Taubaté, Pindamonhangaba e Guaratinguetá produziam mais de 500.000 arrobas de café anuais ${ }^{153}$. Jaelson Trindade nos mostra que nesta mesma época, em 1852, o delegado de polícia Manoel Jacinto Domingues de Castro cita na

\footnotetext{
151 Entrevista com Antonio da Silva Leme, 68anos, que diz em outro trecho da entrevista vir à festa do Divino de São Luiz do Paraitinga há 53 anos, pois, nos quinze anteriores, morava nesta localidade.

152 Coincidência ou não com a origem local pleiteada pelo entrevistado Antonio da Silva Leme, na "Lista Nominativa anual de habitantes da vila de São Luiz do Paraitinga para o ano de 1801" consta como um dos habitantes:

TABELA 2: Lista Nominativa anual de habitantes da vila de São Luiz do Paraitinga para o ano de 1801 Roberto da Silva Leme, 50, soldado m. Taubaté Agricultor

Maria Gonçalves de Figueiredo, m, 19 c.B.

Antonio, f.9, , B

Ana, f, 37, s B

Planta mantimentos para seu sustento Acresce sua filha Rosa nascida neste ano e os

Maria, f, 35, s B escravos Manuel e Maria que comprou de Francisco de Almeida morador desta vila
}

Caetano, e, 61, c, N, cr

Manuel, e, 16, s, N, rebolo

Maria, e, 20, s, N, casange

Fonte: Departamento do Arquivo do Estado de São Paulo. "Maços de População", cx 33

${ }^{153}$ MILLIET, Sérgio. Roteiro do Café e outros ensaios. Bispa Editorial, São Paulo, 1946, página 41. 
região luizense "pequena exportação a saber de cafés, algum toucinho, feijão e milho"154

Jaelson Trindade ainda quantifica:

" a exportação deste município em 6.000 arrobas de café, 1.000 arrobas de fumo e 1.000 arrobas de porcos. Fazendas de café as mais notáveis são as do Padre João Roiz de Moraes, Alferes Manoel Pereira de Castro, Ajudante Luís Gomes de Gouvêa, e Cap. Mor Lopes Figueira, as quaes vão seguindo sofrivelemente (...) a população do município calcula-se segundo algumas informações em 6.000 pessoas" 155

Chama muito a atenção que as fazendas mais notáveis de café vão seguindo de maneira dificultosa, segundo a afirmação do próprio documento em questão. Se prosseguirmos um pouco no tempo, confirma-se ainda mais o papel secundário da produção cafeeira propriamente dita:

" Dez anos depois, a lavoura principal deste município, em que se empregam todos moradores é milho e feijão (...) há a cultura do café, fumo e cana, em pequena escala (...) a exportação dos dois primeiros gêneros monta a do milho em 50.000 alqueires e a do feijão em 20.000 alqueires, sendo a do café e a do fumo em pequena escala" 156

Fica evidente a produção bastante restrita do café em São Luiz do Paraitinga, embora a importância desta monocultura para a cidade nunca possa ser diminuída. São Luiz do Paraitinga não produziu tanto café, mas, se beneficiou, sim, como ponto de parada das tropas, por estar no caminho do transporte destes grãos, entre outras mercadorias. A importância econômica da região beneficiada pela produção do café era imensa ${ }^{157}$, afinal, assim que esta cultura parte para o Oeste paulista em fins do século XIX, a derrocada econômica da maioria das cidades valeparaibanas incluindo, São Luiz do Paraitinga - é notória.

Reafirmo a valorização por parte da maioria da população luizense atual de um passado esplendoroso proporcionado pelo café, transformando aqueles "senhores

\footnotetext{
${ }^{154}$ Departamento do Arquivo do Estado de São Paulo, Ofícios Diversos/ São Luiz do Paraitinga, cx 472, ord. 1267, Pasta-Câmara ofícios do delegado de polícia Manoel Jacinto D. Castro, de 15 de março de 1852 apud TRINDADE, Jaelson, op cit pg 23.

155 Departamento do Arquivo do Estado de São Paulo, Ofícios Diversos/ São Luiz do Paraitinga, cx 472, ord. 1267, ofício de 17 de março de 1852 apud TRINDADE, Jaelson, op cit pg 18.

${ }^{156}$ Departamento do Arquivo do Estado de São Paulo, Ofícios Diversos/ São Luiz do Paraitinga, cx 472, ano de 1862, ofício respondido ao pedido de estatísticas trimestrais em 9 de agosto de 1862. apud TRINDADE, Jaelson, op cit pg 18-19.

157 Só como exemplo, a cidade de Bananal avalizou empréstimos internacionais do governo brasileiro, sobretudo, com a Inglaterra, muitas vezes colocando no café uma espécie de moeda própria como garantia avalizadora. (MAIA, Tom e HOLLANDA, Sérgio Buarque. Vale do Paraíba, velhas fazendas. São Paulo, Cia Editora Nacional e Editora da Universidade de São Paulo, 1975.
} 
do café" em verdadeiros ícones de poder e prestígio. Mais importante que a comprovação proporcionada pelos documentos oficiais - e neste caso específico ela não ocorreu - mostra-se a legitimação histórica construída pelas próprias pessoas a que esta história se refere. Quando nos deparamos com o grosso da população luizense nos dias atuais, vale a pena, sim, reafirmar uma época de abundância na história das festas proporcionadas pelo café - e nunca podemos deixar de afirmar ser este um momento de destaque destas - mesmo sabendo que estes senhores não possuíam tanta riqueza assim.

O que percebemos mais profundamente é a manutenção de uma referência positiva no interior dos grupos de cultura popular luizense atinente àquele pequeno grupo de fazendeiros. Muito mais opressores que incentivadores destas mesmas manifestações populares com suas constantes atitudes de controle, de maneira inconsciente ou consciente por parte dos populares, permitiu-se florear a sua capacidade de plasticidade e de resistência. Toda monocultura, em essência, tem um princípio uniformizador do território e, portanto, prejudicial quando pensamos nesta relação do espaço de vivência do popular. Grandes plantações exigem supressão de espaços ante ocupados por famílias constituintes de esquemas produtivos de subsistência sustentados por relações sociais amplas e fundamentais em seus dia-adias. Todavia, novamente é a sobrevivência das manifestações populares no decorrer da história local, o exemplo mais forte da incapacidade de triunfo de quaisquer estratégias de controle deste mundo.

A monocultura cafeeira mesmo não se expandindo fortemente na cidade de São Luiz do Paraitinga especificamente, modificou completamente toda a região valeparaibana e trafegava constantemente pelo território luizense. Desta forma, temos nesta realidade o elemento principal na construção da memória coletiva atual que não cansa de exaltar um passado rico e marcado por festas exuberantes.

\section{5 - A economia local: da derrocada do café às potencialidades do turismo.}

É interessante perceber então o quanto a riqueza dos grandes produtores de café era algo, pelo menos na região de São Luiz do Paraitinga, muito mais legitimado pela pobreza geral do que por um padrão material muito elevado. 
Ademais, com o desenvolvimento das cidades e dos novos meios de produção, ligados sobretudo aos processos industriais, transformavam-se totalmente os padrões da sociedade brasileira e, mesmo um município com as características de isolamento como o luizense, acabava partilhando os novos padrões.

A primeira tentativa industrial luizense que se tem registro é a fábrica de tecidos "Santo Antônio", propriedade do tenente-coronel José Domingues de Castro. Marcelo Toledo mostra a importância deste empreendimento instalado ainda na década de 80 do século XIX, aproveitando-se do contexto de Guerra Civil nos Estados Unidos, citando a produção de 450 toneladas em 1888, graças a 25 teares movidos por turbina d'água - uma das primeiras experiências brasileiras neste ramo - e empregando cerca de quarenta operários. ${ }^{158}$

Jaime de Almeida relata que o então vereador taubateano Luís Antão da Silva Soares apresenta um projeto em 1905 que alteraria o percurso da estrada de ferro que ligaria Taubaté a Ubatuba, citando essa indústria luizense. Esta estrada, aliás, seria construída a partir de um projeto arrojado para escoar a produção de regiões como sul de Minas, Goiás, Mato Grosso entre outras, entretanto, não foi concluída $^{159}$. A emenda do parlamentar era justificada para beneficiar o escoamento agrícola de cidades próximas, entre elas, São Luiz, que acabara de ter essa sua fábrica de tecidos fechada justamente pela dificuldade de transporte. ${ }^{160}$

A esta altura, os tempos gloriosos do café no vale do Paraíba começavam a ficar associados ao passado. A estrada de ferro D. Pedro II representava um "novo tempo" no escoamento dos produtos agrícolas destinados à exportação e ao abastecimento interno. ${ }^{161}$ Toda aquela cultura de tropas e a necessidade de cidades para o sustento do transporte feito por animais entravam em decadência. E esta tendência estava se constituindo desde meados do século XIX:

\footnotetext{
158 TOLEDO, Marcelo op cit, página 11 baseado em PETRONE, Pasquale, op cit pág 254.

${ }^{159}$ Podemos afirmar que essa estrada foi de fato iniciada, pois, atualmente, ainda encontram-se trilhos em território valeparaibano, inclusive, na região de São Luiz do Paraitinga. Entretanto, não há registro algum que tenha sido colocada em funcionamento em qualquer trecho. O projeto foi abandonado em grande parte devido ao sucesso da construção da estrada D. Pedro II.

${ }^{160}$ Jornal de Taubaté n²065, XII, pág 1, "Estrada de Ferro de São Sebastião; Jornal de Taubaté no 2078 , XII, 16/09/1905, pág.1, Estrada de Ferro apud Jaime de A LMEIDA op cit pg 44.

161 No exame de qualificação o prof. ${ }^{\circ}$ Nicolau Sevcenko atentou para o interesse especulativo dessa modificação da rota cafeeira. Segundo suas pesquisas afirmou existir fortes interesses britânicos em concentrar todo o embarque de café no porto de Santos. Assim acabar-se-ia a possibilidade de ramais secundários, com a produção toda sob controle da elite paulistana em formação e sob seus interesses especulativos.
} 
"Em 9 de fevereiro de 1855, o Governo Imperial firmou contrato com o engenheiro inglês Edward Price para a construção da primeira seção de uma estrada de ferro que visava promover, a partir do Município da Corte (a então cidade do Rio de Janeiro), uma completa integração do território brasileiro sobre trilhos.Foi então organizada a Companhia de Estrada de Ferro D. Pedro II, sob a direção de Christiano Benedicto Ottoni. O projeto mestre tinha como objetivo a construção de uma espécie de "espinha dorsal" entre o Rio de Janeiro e Belém do Pará, que teria conexões com todas as regiões do Brasil através de ramais a serem construídos pela própria companhia, ou, por meio de outras ferrovias. (...) Em 1860, foi concluído o Ramal de Macacos, a partir de Japeri, que era o ponto de partida para que a Estrada de Ferro D. Pedro II atravessasse a Serra do Mar. Em 12 de julho de 1863 os trilhos chegaram a Rodeio (atual Engenheiro Paulo de Frontin) e, no ano seguinte, ao Vale do Paraíba. O primeiro trem de passageiros alcançou Barra do Piraí a 9 de agosto de 1864." $" 162$

Diante da supressão da vocação econômica inicial da cidade luizense e da frustração de novas tentativas econômicas, como essa do algodão, é forte o declínio econômico e populacional que São Luiz passará a enfrentar em meados do século XX. ${ }^{163}$ Acredito poder dizer que se trata do início de uma nova etapa na história local. Surge a necessidade de alternativas àquele estilo de vida característico e o espaço urbano passa a ganhar importância. Era um ambiente para profissionais novos, residentes estritamente no núcleo urbano - algo extremamente raro até então. Uma imprensa periódica começou a se estabelecer já em fins do século XIX e passou a se fortalecer cada vez mais, constituindo um espaço privilegiado de discussões políticas, fundamentais para esta nova etapa da história da cidade.

Remonto as primeiras referências para circulações da imprensa na cidade, ainda do fim do século XIX: o periódico “d’O Paraitinga” surge em 1874; em 1880 circulam "Gazeta de São Luís", "Redenção" e "O Condor"; encontram-se as publicações do Partido Liberal através do jornal "Gazeta de São Luís”. Contudo, é

\footnotetext{
162 Soukef Junior, Antonio. A ferrovia e a cidade : a experiência de Bauru. Tese FAU - FAC ARQ URBANISMO -USP, 2005. páginas 23-25.

163 A tabela transcrita abaixo nos dá um pouco essa noção, por meio de um rápido decréscimo populacional, da crise econômica atravessada pelo município:
}

TABELA 3: População de São Luiz do Paraitinga (1836-1940)

$\begin{array}{cc}\text { ANO } & \text { POPULAÇÃO TOTAL } \\ 1836 & 6.296 \\ 1854 & 10.393 \\ 1874 & 13.894 \\ 1886 & 17.368 \\ 1900 & 29.535 \\ 1920 & 25.166 \\ 1934 & 20.367 \\ 1940 & 11.127\end{array}$

Fonte da Tabela: Pasquale Petrone, op cit página 32 
só a partir do início do século seguinte que esta imprensa ganha em importância, com publicações variadas, demonstrando esta modificação do perfil da cidade. $\mathrm{O}$ maior destaque vai para o jornal "Luizense" (1903-1926). ${ }^{164}$ Abaixo cito um trecho deste periódico que mostra o ambiente de dificuldade, fazendo esta ponte entre a história local e a cultura popular, objeto dessa investigação:

"As várias falas impressas, apesar da virulência com que se enfrentam, harmonizam-se num verdadeiro discurso competente em que algumas imagens, desdobramentos lógicos de segregação fundamental, se repetem constantemente: povo, um doente a ser curado; povo, cadinho racial a ser manipulado para se regenerar a Nação; povo animal a se domesticar" 165

Fazendo jus ao discurso republicano brasileiro, fica evidente, mais uma vez, um momento hostil para as manifestações dos populares. O modo de vida, pautado sobretudo na forma de vida rural, não só estava em crise como era considerado um dos motivos de atraso tecnológico e entrave ao desenvolvimento do país. Toda a região que engloba São Luiz do Paraitinga passou a ser considerada um exemplo a não ser seguido. Era preciso modificar completamente aquele padrão de vida assentado em valores produtivos que deveriam ser completamente abandonados. Era preciso fazer tabula rasa desta tradição rural.

De qualquer forma, se hoje discutimos o espaço do popular na contemporaneidade, o diagnóstico principal deste momento histórico republicano brasileiro, é novamente a capacidade das camadas populares de superar desafios, sejam esses atravessados com uma faceta de resistência ou de adaptação às transformações existentes.

Desta maneira, São Luiz do Paraitinga fez parte de um grupo de cidades da região valeparaibana decadentes economicamente devido a um crescente isolamento que só vem se transformando de alguns poucos anos para cá, acima de tudo pelo turismo. Abaixo, a situação detectada ainda em 1958 e, coincidentemente, por um ilustre luizense, o geógrafo Aziz Nacic Ab'Saber:

" é insignificante a recuperação econômica dos núcleos urbanos não servidos pela estrada de ferro. Esse quadro, não foi possível, ainda, ser alterado

\footnotetext{
${ }^{164}$ ALMEIDA, Jaime. Op cit página 25 e arquivo do CAPH da Universidade de São Paulo.

165 Análise de Jaime de Almeida, op cit página 28, baseada na edição de 05 de fevereiro de 1905 do Jornal "O Luizense", ano II, n 65, citando conceitos que encontramos descrito explicitamente na edição do então veículo mais importante na cidade. O jornal citado encontra-se microfilmado no CAPH/USP.
} 
pela era rodoviária... Dadas as particularidades do relevo da região, as linhas rodoviárias principais se aproximam muito das ferroviárias"

No momento seguinte à decadência cafeeira, São Luiz retornou a uma agricultura pautada na subsistência e uma situação muito próxima àquelas primeiras tentativas de ocupação na época da fundação da cidade. O êxodo populacional foi marcante e as fazendas passaram a se ocupar da pecuária leiteira, em sua maioria, advinda do sul de Minas Gerais. ${ }^{167}$

Este novo ramo dominou a zona rural e toda a economia luizense até pouco tempo atrás. ${ }^{168}$ Somente no fim do século XX, quando o fechamento da maioria das cooperativas de leite instaladas na região começa a ocorrer, a pecuária passa a representar pouco economicamente ao município ${ }^{169}$. O êxodo rural aumentou consideravelmente nesse ínterim e, paralelo a tudo isso, se percebeu uma volta à agricultura de subsistência na zona rural luizense, e pela primeira vez esta passa a ser muito menos representativa para a economia da cidade. Ficava-se, frente a frente, a um novo período de dificuldades econômicas onde o caminho mais comum dos jovens luizenses ainda tem sido a transferência aos municípios vizinhos em busca de oportunidades de emprego.

Nos dias atuais, entretanto, a cidade vem descobrindo uma importante saída econômica pelo desenvolvimento do turismo. Uma saída lucrativa, com certeza, e que se alicerça tanto no ecoturismo como no turismo histórico. As festas populares e religiosas ainda perduram, com destaque justamente à Festa do Divino Espírito Santo, e se vêem todas desafiadas pela nova situação da história econômica da cidade.

\footnotetext{
${ }^{166}$ AB'SÁBER, Aziz Nacib; BERNARDES, Nilo. Vale do Paraíba, Serra da Mantiqueira e Arredores de São Paulo. Guia de Excursão número quatro. XVIII Congresso Internacional de Geografia. Rio de Janeiro: Conselho Nacional de Geografia, 1958. Página 49.

${ }_{167}^{167}$ Jaime de ALMEIDA, op cit, pg47.

${ }^{168}$ Costumeiramente criticamos muito a produção cafeeira do século passado e o aumento do plantio de eucaliptos atualmente como monoculturas devastadoras do solo e da cultura luizense. Porém, a pecuária leiteira, que dominou a grande parte do território luizense por décadas no século XX, tem como lógica o desemprego rural e a devastação natural. Afinal, poucas pessoas são suficientes para cuidarem de rebanhos imensos e que ocupam, naturalmente, grandes espaços na zona rural.

169 Ainda hoje muitos sitiantes mantêm uma produção leiteira. Entretanto, a representatividade da pecuária leiteira para a economia da cidade passou a ser ínfima, a não ser quando tomamos contato com iniciativas de grandes investidores locais como a família Saad, proprietária da rede de comunicações Bandeirantes, esta atividade tem importância econômica. No restante está praticamente abandonada.
} 
Resta descobrir, entretanto, se as festas luizenses que vêm sendo geridas com vistas a este "mercado" proporcionado pelo turismo ${ }^{170}$, têm levado em conta toda sua importância, marcadamente histórica e espiritual, ou vêm caminhando em direção à mesma massificação da cultura que ocorre nos principais pólos de turismo cultural do país.

De qualquer forma, o turismo tem permitido uma nova saída, uma espécie de "nova luz" para o futuro econômico da cidade. Embora aqui eu sempre tenha reafirmado a importância da cultura da cidade luizense em toda sua história, nem sempre é possível, quando nos deparamos com esse percurso econômico descrito rapidamente, fugir da clássica classificação de Monteiro Lobato: "umas tantas cidades moribundas arrastam um viver decrépito, gasto em chorar na mesquinhez de hoje as saudosas grandezas de dantes". ${ }^{171}$

Entretanto, o que um juízo como esse não abarca, é justamente o cerne da sustentação de uma nova realidade dessa cidade: a importância da tradição cultural construída e amparada a partir da superação de todos os percalços da história econômica e política da cidade. Mais uma vez advirto com obstinação para esta capacidade mais do que de resistência, de superação das adversidades pelas camadas populares.

O modo de vida atual da população luizense é altamente valorizado, principalmente, pelos principais meios pensantes da sociedade, pela suas relações culturais mantidas a partir deste paradoxo entre tradição e modernidade. Precisamente o oposto da conclusão de Lobato, as relações culturais pautadas na tradição são muito mais complexas e frutos de uma temporalidade muito maior do que costumamos imaginar. Constituem o avesso de uma concepção senil, sendo muitas vezes a solução das dificuldades dos processos globalizantes.

E, foi graças a essa cultura popular resistente que a cidade conseguiu construir um "status positivo" nos dias atuai ${ }^{172}$. Afinal, se fosse depender da economia, a história seria completamente diferente, ou melhor, provavelmente

\footnotetext{
${ }^{170}$ Falo nesses termos pois veremos à frente o quanto tem aumentado a ingerência do poder público sobre as manifestações populares na cidade luizense.

${ }^{171}$ LOBATO, Monteiro. Cidades Mortas. Editora Brasiliense, São Paulo, 1977, página 3.

172 Por "status positivo" entende-se este destaque ocupado cada vez mais pela cidade de São Luiz do Paraitinga nos principais meios de imprensa e nas discussões acadêmicas.
} 
estaria de acordo com a realidade detectada por Monteiro Lobato. O próprio turismo

- obviamente partindo do aspecto econômico - tem se fortalecido por defender a bandeira da cidade da cultura popular. 


\section{Capítulo III - A história da Festa do Divino de São Luiz do Paraitinga e suas características peculiares}

Espero que tenha ficado evidente na discussão de algumas passagens da história do município luizense feitas no capítulo anterior, a primordial representatividade da cultura popular no dia-a-dia do cidadão desta localidade. E, justamente por ser essa a busca fundamental dessa pesquisa, a escolha da Festa do Divino como tema principal de análise soou, praticamente, como algo imperativo, advindo dos anseios da própria comunidade no contato durante os primeiros estágios da pesquisa. Eram muito comuns pedidos dos luizenses mais próximos para que eu estudasse a festa do Divino de São Luiz do Paraitinga em minhas pesquisas.

É no interior dessa festa que diversos elementos constituintes da identidade do popular afloram. Buscarei nesse capítulo, portanto, fazer a ponte entre alguns acontecimentos com determinados conceitos característicos da cultura popular como um todo. Memória coletiva, identidade de grupo, reciprocidade, religiosidade popular, resistência, autonomia são alguns dos temas presentes no "mundo do popular" de uma forma geral, e que no caso específico de São Luiz do Paraitinga possuem nas festividades em louvor ao Espírito Santo palco privilegiado de representatividade.

É incrível a força dos preparativos e o envolvimento da comunidade em torno da festa durante toda a história do município e o quanto isso ainda se mantém. Seja os que realmente se empenham na realização desta - incluindo aí tanto os que se dedicam à parcela dos aspectos religiosos das comemorações quanto aqueles dedicados à dita parte mais "profana" - ou mesmo os membros da comunidade que não se envolve diretamente nos acontecimentos, não há como negar o quanto a festa exerce um papel primordial na sociabilidade dos luizenses.

Discutir o sucesso da festa, criticar atitudes tomadas pelos organizadores, modificações, continuidades, são assuntos que reverberam por meses no município e acabam ressoando por toda a região. Veremos, por exemplo, o quanto o poder público vem assumindo funções antes realizadas pela própria comunidade na realização das festas e o quanto isso provoca discussões acaloradas entre os 
munícipes. Ou o quanto se torna conflituosa a relação da Igreja com a população quando alguns temas tradicionais da festa são questionados pelo clero, buscando-se uma linha mais propícia a um maior controle episcopal.

Destaco essas situações específicas não apenas pela sua importante função de revelar aspectos políticos que se tornam claros durante os eventos e toda a produção da festa do Divino. São desafios provocadores que acabam por reforçar os princípios fundamentais que unem as pessoas, permitindo a consolidação de um modo de vida pautado, acima de tudo, pelos valores coletivos, simbólicos e imateriais reforçados como contraponto às tentativas de dominação e controle.

Tanto ao participar dos eventos da festa - veremos como seus acontecimentos percorrem todo o ano - como ao discutí-la, estará se dando voz e consolidando essa identidade da cultura popular luizense. A Festa do Divino Espírito Santo de São Luiz do Paraitinga constitui-se, dessa forma, num palco privilegiado de análise nessa nossa busca do entendimento da cultura luizense dentro da modernidade.

Revela, principalmente, muito da temporalidade mais ampla das manifestações populares, à qual devemos sempre atentar. Qualquer pessoa que interroguemos sobre a origem da festa, dificilmente apontará uma versão que não ligue o catolicismo à sua fundação. E mesmo não buscando diminuir a importância fundamental da Igreja Católica na perpetuação da festa em nosso país, é impossível discutí-la sem se aproximar de sua origem pagã, remontando-se à Idade Média ocidental. Muitas atitudes tipicamente pagãs se mantêm ainda na atualidade e na grande maioria das vezes, sincretizadas aos próprios aspectos religiosos.

Não há grande surpresa quando encontramos um grupo de congada se apresentando nas festas do Divino, cujos integrantes freqüentam, por exemplo, cultos de umbanda paralelamente à devoção ao Espírito Santo. Pessoas que ainda, na quase a totalidade dos casos, possuem uma relação com o sagrado na maioria de suas manifestações autônoma da Igreja. Nem por isso, deixam de se considerar católicos e apresentar uma profunda veneração aos cultos católicos. Aliás, o próprio clero - que entra muitas vezes em conflito com esse tipo de situação - acaba constituindo uma atuação cuja tônica é uma relação amistosa e de negociação com 
essas situações. Obviamente, mais pela força do popular do que vontade própria da instituição.

Situações como essa servem à confirmação da especificidade da identidade, da temporalidade, do espaço, ou seja - e pensando de uma forma mais ampla - da concepção de mundo especial da cultura popular. Teremos contato com alguns exemplos concretos de ssas situações através da história da Festa do Divino luizense e, perceberemos, que mais abrangente que pensar como é possível a sobrevivência de tradições populares na modernidade, é perceber ser esse "apenas" mais um dos tantos desafios enfrentados pelo "mundo do popular" no decorrer da história.

A Festa do Divino Espírito Santo surge como um campo fortíssimo para corroborar essa energia do popular. Reforça-se ainda mais a riqueza e a complexidade de suas manifestações, quando percebemos o quanto uma festa tipicamente da elite em sua origem, sempre ligada às irmandades brancas, as mais poderosas desde a colônia, e reforçadora dos valores da realeza - não é à toa que símbolos como a coroa e o cetro aparecem como primordiais - consegue expor, o protagonismo do popular. É incrível a capacidade de superação e autonomia destes sujeitos sempre classificadas negativamente como pessoas muito "simples".

A festa acaba sendo mantenedora de rituais que mostram a continuidade do papel exercido por essa cultura popular, que muitos ainda dizem estar em vias de desaparecimento.

\section{1 - Os cultos pagãos incorporados pelo catolicismo nas festas do Divino Espírito Santo}

Uma das versões mais aceitas é a de que a festa do Divino Espírito Santo tem sua origem nos cultos pagãos existentes na Idade Média, sobretudo, na região da atual Alemanha ${ }^{173}$. As festas populares, naquela época, tinham tanto a preocupação com o agradecimento às divindades quanto relativa às colheitas. Eram realizados

${ }^{173}$ FLORENÇANO, Paulo Camilher. A Festa do Divino Espírito Santo. Taubaté. Museu e Arquivo Histórico de Taubaté, mimeografado, (1985), apud CAMPOS, Judas Tadeu. Festa do Divino Espírito Santo em São Luiz do Paraitinga: decadência ou transição? in Revista de Ciências Humanas da Universidade de Taubaté. Volume 3, número 2, páginas 23-32, juldez, 1997. 
rituais de proteção e para a melhoria da produção rural. As pessoas acreditavam que assim suas produções ficariam imunes às pragas e a outros malefícios que por ventura ocorressem, advindos da natureza. A festa então era ligada aos ciclos agrícolas, tendo como data o chamado solstício de verão (22 ou 23 de junho) onde o Sol passa pela sua maior declinação boreal. ${ }^{174}$ Foi levada para Portugal já por volta do século XIV, no reinado de D. Izabel (1271-1336), esposa de D. Diniz (12611325), o Lavrador. Entretanto, só adquiriu suas feições católicas como a identificamos hoje, no reinado da homônima D. Isabel, agora, a de Castela (14701498), esposa de D. Manoel, o Venturoso, de onde advém, naturalmente, a principal face da origem brasileira dessas comemorações.

Antes de entrar nesse histórico gostaria, entretanto, de recuar um pouco mais, voltando à Antiguidade Clássica e buscando a correspondência entre ritos daquela época e as festividades que surgiram em louvor ao Divino. Tem sempre que estar muito claro tratar-se de manifestações muito diferentes no tempo e no espaço que trazem, entretanto, uma raiz comum e signos semelhantes. Mesmo que sempre partamos de nosso presente como sintetiza tão bem David Lowenthal:

"Memory, history, and relics of earlier times shed light on the past. But the past they reveal is not simply what happened; it is in large measure a past of our own cration, moulded by selective erosion, oblivion, and invention. (...) how these forces have reshaped the known past for every individual epoch, and how since the Renaissance that past has become more and more a foreign country distinct from the present, yet at the same time increasingly manipulated by present-day aims." 175

A respeito dessa origem histórica, é muito interessante o trabalho de Rita de Cássia Silva ${ }^{176}$, afirmando que as festas mais disseminadas na Antiguidade Clássica eram justamente as ligadas aos solstícios. Elas representavam o auge da movimentação do astro solar, que, depois de ir progressivamente subindo, chega ao ponto mais alto no céu e passa a fazer o caminho inverso. É a representação do fím de um ciclo: aparentemente o momento mais apropriado para novos projetos e

\footnotetext{
${ }^{174}$ Muitas vezes acaba passando despercebido pela gente a diferença óbvia de que, no Brasil, o solsístico é de inverno (22 ou 23 de junho).

${ }^{175}$ LOWENTHAL, David. Introduction in The Past is a Foreign Country. Cambridge University Press: New York, 2003., pg 10.

${ }^{176}$ SILVA, Rita de Cássia. Entre o velho e o novo - A festa do Divino Espírito Santo de Anhembi. Mestrado em Ciências Sociais, PUC/SP, São Paulo, 2003.
} 
pedidos. O fim de um ciclo agrícola conta, salvo fracasso por questões naturais, com colheita, fartura, sendo um momento muito propício à realização de uma festa.

Há na história da humanidade uma preocupação constante com a busca de garantia alimentar, e conseqüentemente de sobrevivência, presente no cotidiano das mais remotas civilizações conhecidas. A ameaça de grandes fomes e epidemias nos faz entender mais facilmente a força que adquiriam as manifestações solicitantes de proteção alimentar às divindades no decorrer da história. É justamente o poder de congregação que essas dificuldades proporcionavam às populações a elas submetidas, e a reverbação cultural decorrente desses desafios, um dos maiores trunfos da perpetuação alcançada pelas tradições populares. Eduardo Etzel, em seu trabalho sobre o simbolismo na arte popular, reforça o argumento da preponderância de rituais festivos nas civilizações antigas ligadas ao princípio fundamental da luta pela sobrevivência humana e propagador de muitas tradições no decorrer da história:

"Este é o elemento básico e imutável que está no cerne do folclore e se manifesta sob os mais variados disfarces, subordinados à religião ou às ideologias, mas sempre aflorando no variado comportamento do povo"177

Fica clara, assim, a identificação da origem da festa do Divino nas sociedades predominantemente rurais, organizadas para o agradecimento e pedidos por boas colheitas. Pedidos esses baseados em rituais ligados às mais diversas divindades naturais.

Ao mencionar os elementos pagãos absorvidos pelo cristianismo, refiro-me à própria denominação latina paganu + ismo que permite a designação de todas as formas de atitudes religiosas politeístas advindas de qualquer pessoa ou grupo social, através da idolatria às imagens e símbolos personificados. ${ }^{178} \mathrm{Na}$ Antiguidade, era a religião o cerne de qualquer acontecimento, englobando em seu campo de influência o governo e a justiça, sendo assim determinante para todas as regras materiais e espirituais da comunidade. Tanto as leis como o modo de vida em geral não significaria mais do que a representação subentendida do poder das divindades.

\footnotetext{
177 ETZEL, Eduardo. Divino. Simbolismo no folclore e na arte popular. São Paulo: Giordano, 1995, página 37.

${ }^{178}$ AZEVEDO, Antonio Carlos do Amaral. Dicionário de nomes, termos e conceitos históricos. $3^{\mathrm{a}}$ edição. Rio de Janeiro: Nova Fronteira, 1999.
} 
Não há como pensar em termos de indivíduo em uma situação como esta, ficando reforçado o aspecto coletivo quaisquer que sejam as simbologias de origem pagãs. Uma não correspondência entre os entes excluía qualquer indivíduo de atribuições sociais, tornando-o desprotegido das divindades e impotente. É o avesso da modernidade onde o sucesso individual é sempre muito valorizado. Nas festas populares atuais, como a do divino de São Luiz do Paraitinga, permanece esta preponderância do sentimento coletivo.

Rita de Cássia coloca que o grande trunfo do Cristianismo foi exatamente ter admitido a absorção de características tipicamente pagãs permitindo uma incorporação da maior parte da população, independente de riquezas, hierarquia e etnia. As pregações de Jesus Cristo sempre se referiram a toda a humanidade. Mesmo com Deus sendo imposto como algo individual em oposição aos princípios politeístas, a institucionalização de uma "nova" religião foi capaz de transcender as diferenças, estabelecendo uma flexibilidade. Muitos dos símbolos e rituais pagãos foram apropriados e difundidos permitindo essa identificação.

“ Segundo Bertrand Russel, a princípio o cristianismo foi pregado de judeus para judeus, como uma reformulação do judaísmo. Esta era a proposta de São Tiago e, em menor grau, de São Pedro, apóstolos que defendiam essa idéia. No entanto, se não ocorresse a intervenção de São Paulo em admitir os pagãos, sem exigir a circuncisão ou a submissão à Lei Mosaica, provavelmente a idéia da reformulação do judaísmo teria se concretizado, e não se constituiria em base para uma religião que pretendia abranger a maioria populacional."179

Quando observamos o recolhimento de uma prenda pelos grupos de folia, com uma força ainda maior na zona rural, reforça-se a crença na ligação direta com a natureza. Mais do que esperar uma benção do clero institucionalizado, a família doadora tem a certeza de que, por exemplo, ao entregar uma de suas melhores reses para o Divino, será retribuída por uma grande colheita ou uma proteção a esse rebanho que tenderá a procriar-se ainda mais, ou seja, os símbolos de fertilidade advindos das forças naturais são os preponderantes. É a ligação direta com o sagrado, ainda fortalecida na atualidade e cada vez mais objeto das diversas indisposições entre a população e o clero, ocasionadas por uma relação evadida dos

\footnotetext{
179 Rita de Cássia Silva (2003) (op cit). A referência do autor Bertrand Russel é a obra História da Filosofia Ocidental. São Paulo: Companhia Editora Nacional, 1969
} 
controles institucionais. Observemos o relato do folião Brás - líder da folia do Divino e que percorreu o município luizense em 2006 e 2007 - exemplar desta situação:

“ O mais interessante é perceber a fé que o povo tem no poder do Divino. As pessoas quanto mais simples parecem que doam mais. Lógico que quem é mais rico doa mais em valor, mas falo em o quanto representa o que doa para aquela pessoa, mesmo, você me entende?... Uma pessoa, às vezes, muito pobre, tira de seu pequeno gado a novilha mais bem tratada e que mais dá leite, porque tem a certeza que receberá muito mais em troca, mesmo que por um tempo passe necessidade pela falta desta. (...) As coisas vem mudando muito em nosso mundo mas uma coisa se mantém, a fé do povo no que a natureza garante. O Divino, sabe, ele é muito mais forte que o padre, que a Igreja até..." 180

O exemplo de absorção do culto às divindades - através da ligação com as colheitas - pelo Cristianismo transformando-o em comemoração a Pentecostes ${ }^{181}$, não se trata de caso único na história da Igreja. Pelo contrário, há muitos exemplos como uma festa que ocorria anualmente em comemoração à deusa Diana, na Antiguidade italiana, foi incorporada pela Igreja como a tradicional festa de Assunção de Nossa Senhora, comemorada no dia 15 de agosto. Na Antiguidade não era permitido maltratar animais selvagens nas comemorações e os cães de caça eram idolatrados. Em homenagem à deusa Diana, as jovens da época eram purificadas em rituais repletos de abundância tanto de comida quanto de bebida. Segundo Frazer ${ }^{182}$, tanto a comemoração da Antiguidade quanto o culto à Nossa Senhora trazem como sentido primordial a proteção à colheita, especificamente, às colheitas de vinhas.

Outra festa conhecida pela cultura católica e intimamente ligada ao paganismo é a de São João Batista. Frazer ${ }^{183}$ demonstra a substituição de Adônis deus do Mediterrâneo antigo - pelo santo católico. As provas para este autor são a

\footnotetext{
${ }^{180}$ Entrevista em 12 de abril de 2007 com mestre Brás, o mestre da folia do Divino que percorreu toda a região em 2006/2007. Não poderia deixar de relatar aqui a sua preocupação sobre como eu iria colocar o seu depoimento no trabalho, pois, afinal o padre poderia repreendê-lo pela afirmação de que o Divino representasse maior importância. A transcrição como colocada acima foi conferida e aprovada pelo mesmo.

${ }^{181}$ Cabe ressaltar a importância da Igreja Católica para a manutenção dessa festa no decorrer da história de nosso país. Seja por possuir aquela tradição de uma religiosidade mais popular - talvez, um dos principais motivos pelos quais esta festa tenha se mantido com vigor em nosso país -, o fato é a possibilidade de continuidade que a Igreja permitiu, mesmo com todos os conflitos, através de uma estrutura constante e fortalecida de sustentação à festa do Divino.

${ }^{182}$ FRAZER, James. O ramo de ouro. Rio de Janeiro: Guanabara Koogan, 1982, página 85.

${ }^{183}$ FRAZER, James. Op cit, pág 86.
} 
semelhança da data originária da festa em junho, o papel destacado da água e de vasos de cereais e ervas em ambas as comemorações e, por fim, a ligação com a renovação nos dois casos. Enquanto São João Batista representa para a fé católica um exemplo de vida e dedicação, o deus Adônis também proporcionava um modelo semelhante na Antiguidade. Através de sua morte e ressurreição, análogas à morte da natureza no outono e seu ressurgimento na primavera, Adônis concebia valores similares aos da dedicação à vida de São João Batista, pautados, entretanto, diretamente nos valores naturais.

A Festa do Divino Espírito Santo carrega muito das simbologias pagãs e confirma a temporalidade mais ampla das manifestações populares. É necessário despirmo-nos de uma análise mais mecânica, que busca delimitar o surgimento de manifestações na história estritamente pelo caráter apresentado pelas manifestações contemporâneas. Veremos a seguir eventos tradicionais do culto ao Espírito Santo na Europa Moderna, especificamente em Portugal, sua chegada ao Brasil e a São Luiz do Paraitinga. Entretanto, esvaziar-se-á totalmente o sentido dessa proposta, caso não ocorra uma busca das tradições pagãs onde se assentam muitas manifestações presentes na história desta festa.

Se pensarmos na própria doutrina católica, a complexidade de um tema como o da Santíssima Trindade acaba permitindo interpretações variadas, transparecendo muito mais atitudes de devoção do que compreensão da ortodoxia da fé. Flávia Raveli $^{184}$ nos remete a uma argumentação que confirma isso, referindo-se ao pesquisador religioso Beozzo:

“ O tema do Espírito Santo fugiu à manipulação pelo poder dominante e emergiu com as manifestações sempre mais evidentes da religião popular em tempos recentes. A rápida aceitação por parte do povo, da experiência extática cultivada em cultos sobretudo pentecostais demonstra que sempre houve uma conaturalidade entre o tema do Espírito Santo e a religião popular: o Espírito Santo se 'manifesta' pela expressão corporal, meio de comunicação próprio dos oprimidos aos quais a expressão verbal está sendo negada" 185

\footnotetext{
${ }^{184}$ Flávia Raveli, op cit, pág 48.

185 BEOZZO, José Oscar, e outros. História da Igreja no Brasil. $1^{a}$ época. Tomo II/I. São Paulo, editora Paulinas, Petrópolis, editora Vozes, $4^{\mathrm{a}}$ edição, 1992 apud Flavia Ravelli, op cit.
} 
É a confirmação da preponderância do popular mesmo se tratando de uma festa organizada pelas principais irmandades brancas, detentoras do poder político nas sociedades européias e, por correspondência, na sociedade colonial brasileira. $\mathrm{O}$ profano engloba todas essas manifestações de referência exaltação do corpo comida e bebida abundantes; assim como um momento de exceção proporcionado pela festa, quando os homens reiteram um sentido de ordem no mundo advindos de si próprios, pensados coletivamente.

A festa do Divino foi o evento escolhido como prioritário para demonstrar parte da complexidade que constitui o "mundo popular" de uma forma geral, utilizando São Luiz do Paraitinga como exemplo. Todavia, as festas que representam momentos de exceção no funcionamento das comunidades, são o afloramento natural da concepção de mundo que as pessoas carregam:

“ É a materialidade e concretude da vida, remetentes à realidade e ao cotidiano dos homens, símbolo e canal de expressão, ao mesmo tempo, da rememoração, da memória da história e da vida que é a festa, o festar". ${ }^{186}$

\section{2- As principais influências da Festa do Divino brasileira}

Como já dito, embora a comemoração em homenagem ao Divino Espírito Santo brasileira esteja toda assentada na tradição portuguesa - destacando-se, inclusive, a particular influência açoriana - são diversas as origens desta manifestação. É interessante, por exemplo, o papel desempenhado pela região alemã ${ }^{187}$, como uma espécie de protagonista dos primeiros cultos cerimoniais ainda pagãos - que serão as bases na estrutura dos eventos em louvor à terceira pessoa da Trindade, propagando-se por todo o território europeu, sob os padrões cristãos, a partir do século XIV.

Ana Maria Araújo elege no milenarismo de Joaquim de Fiore o embasamento teórico que definitivamente coloca o culto do Divino em prática no continente

\footnotetext{
186 BRANDAO, Carlos R. A Cultura na rua. Campinas, editora Papirus, 1989, páginas 11-12.

187 Atentar que me refiro à região alemã, pensando nos povos germânicos que, segundo o folclorista Alceu Maynard, receberam tradições românicas de distribuição de alimentos e cerimônias ligadas ao círculo das colheitas. Ver ARAUJO, Alceu Maynard. Folclore Nacional I: festas, bailados, mitos e lendas. $3^{\text {a }}$ edição, São Paulo: Martins Fontes, 2004, páginas 25-29.
} 
europeu. ${ }^{188}$ Ligado a essas tradições pagãs, surge um discurso de assistência social aos mais desfavorecidos, formando, desde a Baixa Idade Média, um contraponto ao constante sofrimento do povo com as epidemias, fomes e guerras.

Aquele pano de fundo de extrema pobreza da Europa, aliado à difusão de uma mensagem do fim dos tempos apregoados pela vitória divina, permitiu a esse movimento, consagrado posteriormente por Joaquim de Fiore, monge italiano morto no início do século XIV, capitanear a ansiedade por esperança, imbuída de sonhos revolucionários depositados em "novas" crenças através do sagrado. Era necessário erigir uma Igreja mais igualitária e pura, recusando todas formas de riqueza material. O caminho do culto ao Espírito Santo torna-se assim facilitado pois, segundo o historiador Le Goff, acabar-se-ia por retomar, também da Antiguidade, uma espécie de crença na "Idade de Ouro", onde imperaria a ausência das desigualdades entre os homens. ${ }^{189}$

Ana Maria Araújo ${ }^{190}$ mostra essa ponte entre o mundo riquíssimo de tradições pagãs e a institucionalização dos cultos ao Divino pelo cristianismo, citando essa situação típica do discurso do auxílio aos homens. O caso evocado trata-se da defesa da população, sofredora das epidemias e fomes:

" Fomes apertadas nos estados alemães determinaram um dos imperadores da dinastia, Othon, a lançar os fundamentos dessa instituição como banco formado de esmolas para acudir a pobres nos anos de penúria. Da divindade que invocam, do imperante que tomara a iniciativa, nasceram os festejos religiosos, que a confraria imperial votava ao culto do Espírito Santo nesta quadra do ano, devoção e costume que de lá se propagou pelos Estados da Europa Cristã..." 191

A Rainha portuguesa D. Kabel (1271-1336) - esposa de D. Diniz (12671325 ) - é por muitos apontada como a primeira referência dessa festividade dentro dos padrões cristãos, graças a um acontecimento milagroso e que se liga à tradição da distribuição de alimentos, por sinal, sempre presente na festa. Como sabemos, a distribuição farta do "afogado" - cozido de carne com batatas - por toda a história

\footnotetext{
188 ARAUJO, Ana Maria Ramalho Câmara de. A Festa do Divino e suas transformações na comunicação e na cultura. Dissertação de mestrado, PUC/SP, São Paulo, 2003.

${ }^{189}$ LE GOFF, Jaques. História e Memória. Campinas, 4ª edição, Campinas: Unicamp, 1996, páginas 238-240.

${ }^{190}$ ARAUJO, op cit, página 11.

${ }^{191}$ I.Torres apud SIMÃO, Voigt. Vocabulário de Teologia Bíblica. Petrópolis/RJ, Vozes, 1999.
} 
da festa do Divino luizense carrega muito daquele pacto pagão do retorno da fartura proporcionada pelas prendas oferecidas ao Divino em sua relação íntima com a natureza e as colheitas. Na verdade, a distribuição de alimentos é um elemento encontrado em praticamente todas as festas do Divino espalhadas por nosso país e que se liga a esse milagre da Rainha D. Isabel, esposa de D. Diniz.

O folclorista Alceu Maynard nos conta que a distribuição de alimentos surge desde os primórdios da festa do Divino: há algumas versões de sua ligação com tradições típicas dos povos germânicos; outra, que seria derivada do panis gratilis da civilização romana levada a Portugal; ou ainda proveniente do milagre de D. Isabel, dizendo ainda Maynard, que se trata de uma crença muito forte, absorvida e disseminada pelo cristianismo ${ }^{192}$. A rainha D. Isabel tinha como prática muito prazerosa a distribuição de esmolas aos pobres, ação, porém, interdita pelo seu próprio esposo, D. Diniz. Nem por isso deixava de exercer aquela que considerava sua missão e, certa vez, se deparou com o Rei com inúmeros pães escondidos no avental e rapidamente lhe disse tratar-se de rosas. O Rei, descrente, quis vê-las e milagrosamente eles haviam se transformado em rosas. ${ }^{193}$

A festa se espalha por toda a Europa, mas, é principalmente em Portugal que ela cresce e adquire as feições mais próximas daquelas praticadas em nosso país na atualidade, uma festa extremamente concorrida e tendo como principal marca a maciça participação popular.

" o historiador memorialista Vieira Fazenda (...) consultando uma erudita bibliografia portuguesa, já havia explicado que as festas de Pentecostes, onde se homenageava o Espírito Santo, eram as únicas, no século XIV, em que Ordenações do Reino permitiam a tradicional distribuição de comida aos pobres. (...) Vieira Fazenda ainda reúne informações sobre a realização da festa do Divino nos Açores, nos séculos XV e XVII onde eram mantidos o 'império dos nobres' e a distribuição de comida e esmola aos pobres "194

Martha Abreu com esse exemplo nos mostra as duas faces paradoxais e concomitantes no interior das festas do Divino. Embora sempre preguemos a maciça

\footnotetext{
192 A rainha D. Isabel transformou-se em Santa Isabel para a Igreja Católica.

193 Ver ARAUJO, Alceu Maynard. Festas, bailados, mitos e lendas, volume 1. São Paulo: Melhoramentos, 1964 apud Ana Maria Araújo, op cit.

${ }^{194}$ Fazenda Vieira apud Martha Abreu. O Império do Divino- Festas religiosas e cultura popular no Rio de Janeiro, 1830-1900. Rio de Janeiro: Nova Fronteira; São Paulo: Fapesp, 1999, página 39.
} 
participação popular nas festas do Divino, esta nunca deixou de ser organizada apenas por pequenas parcelas da população: a princípio pela nobreza ${ }^{195}$, pelas irmandades ligadas à própria nobreza e ao clero na sua propagação pela colônia, ou por pessoas com poder político local no decorrer da história. No caso específico de São Luiz do Paraitinga é fácil citar a preponderância dos grandes produtores de café como festeiros escolhidos no período que vai do fim do século XIX até meados do XX, época do auge dessa manifestação no vale do Paraíba paulista e fluminense.

Voltando a algumas versões sobre o histórico da festa, outro pesquisador que atribui à rainha $\mathrm{D}$. Isabel a primeira realização de uma festa do Divino como a cultuamos em nosso país, é Câmara Cascudo, através da existência de um monumento em homenagem a essa festividade, construído a mando desta mesma rainha ${ }^{196}$. Data das primeiras décadas do século XIV a construção da Igreja do Espírito Santo em Alenquer, localidade considerada como sendo a principal área de influência de D. Isabel e símbolo de suas ações. Na verdade, toda a vila de Alenquer havia sido entregue à rainha $\mathrm{D}$. Isabel por contrato nupcial, seguindo o acordo introduzido por D. Sancho I. ${ }^{197}$

Se era a intenção desta rainha o cumprimento daquela missão que a santificara pelo auxilio aos pobres e a institucionalização de uma festa que colocasse em prática essa necessidade da época de ajudar os desfavorecidos, nada seria melhor que a introdução da festa acontecesse em uma região marcadamente identificada com a sua figura, o que de fato aconteceu.

O site português do padre José Ferreira ${ }^{198}$ oferece testemunhos de cronistas antigos - infelizmente, não identificados com clareza - mas que são frutos de pesquisa de João Lupi e que destacam tanto os fundadores da celebração como as características iniciais que estamos apontando:

\footnotetext{
${ }^{195}$ Mesmo no caso específico da rainha D. Isabel embora fosse de destaque sua ação de distribuição de alimentos, seus principais convidados às festividades em louvor ao Divino seriam sempre os nobres. Ver Martha Abreu, op cit.

196 CASCUDO, Luís da Câmara. Dicionário do folclore brasileiro. Editora São Paulo: Global, 2001, págs. 560-562.

197 LUPI, João. As festas do Divino Espírito Santo. Apud CHAVES, Robson Belchior Oliveira. Salesópolis - Festa do Divino: das origens aos dias atuais. Dissertação de mestrado, PUC/SP, 2003.

198 http://www.portugal-linha.pt/opiniao/jferreira/jf6.html. Também referido no trabalho de Chavez, Robson, op cit, mas, que tive a oportunidade de acessar integralmente no mês de maio de 2007.
} 
“... A Rainha Santa Isabel e el-rei D. Dinis seu marido foram os autores da festa que se chama do Espírito Santo, cuja solenidade foi tão célebre por todo o reino (...) Aqui em Alenquer se celebra ainda esta acção, que chamam do império, com grande aparato (...) E entre outras devoções, a Rainha Santa introduziu um modo, que chamam impérios, e na festa de Pentecostes instituiu um bodo com abundancia de pão, bolos, carnes e outras coisas comestíveis..." 199

Mais importante do que delimitar um nome, como o da rainha santa Isabel como fundadora, desenvolvi essa argumentação para poder demonstrar as características iniciais presentes nas comemorações análogas a muitas das manifestações das festas da nossa atualidade. Mesmo porque a origem da festa é muito mais complexa que o papel exercido por apenas uma pessoa e já que vimos toda a origem ligada aos círculos do paganismo, não podemos deixar de citar mais um aspecto fundamental: o papel das irmandades, desde a Europa, para aí sim entendermos a sua importância também primordial para as festas brasileiras.

Inicialmente organizadas pelas cortes, a festa passa às mãos das irmandades do Espírito Santo, formadas por devotos a essa divindade e diretamente ligadas às autoridades eclesiásticas que as aprovavam e controlavam. Apesar da forte elitização dessas irmandades que sempre eram indicadas pelo clero como forma de representatividade e legitimidade do poder religioso e político perante a população, obras concretas de assistência social, que seriam adicionadas às funções espirituais, permitiam sua popularização. Podemos citar entre elas as visitas aos doentes, presos e resgates de escravos.

A tradição de assistência social foi transferida também às festas brasileiras e para a luizense especificamente. Um documento confirmador dessa tradição é o Programa da Festa do Divino de 1916, parte do acervo pessoal de dona Benedita Antunes de Andrade ${ }^{200}$ que confirma esse evento relacionado aos presos e, traz conjuntamente a confirmação da importância do papel das irmandades na organização das festas do início do século passado:

\footnotetext{
${ }^{199}$ Idem nota anterior.

${ }^{200}$ Discutirei logo a frente a importância de dona Didi Andrade - como é chamada dona Benedita pela população - que há mais de cinqüenta anos é uma das principais responsáveis pela organização das festas do Divino. Desempenha ainda um papel ativo na cidade em todos eventos relacionados a cultura, chegando inclusive a ostentar o título de primeira mulher na vereança da cidade.
} 
“ SEXTA-FEIRA 22 - as 10 horas, almoço aos presos da Cadeia Pública

(...)

Para que as solennidades religiosas a se affectuar tenham colpeto êxito e o brilhantismo precioso, o festeiro abaixo assignado, solicita o valioso concurso de todas as irmandades religiosas da parochia, e bem assim, convida não so ao povo desta cidade e município como tambem ao das cidades e localidades visinhas, para comparecer ás mesmas.

O FESTEIRO José Bernardino de Castro"201

Seguindo no tempo, tive contato também justamente com a reclamação sobre a quebra da tradição de visita aos presos pelo "Semanário de Taubaté" no ano de 1949. A denúncia foi feita por Mário Aguiar, autor de vários artigos sobre São Luiz do Paraitinga: ${ }^{202}$

“ A 'casa da festa' perdeu, também, um dos seus característicos de solidariedade social, pois está abolida a visita que se fazia aos presos da cadeia local durante aqueles dez dias, levando-se-lhes um pouco de tudo quanto era oferecido àqueles a quem a liberdade permitia tomar parte ativa em todos os festejos". 203

O momento da quebra de uma tradição fica claro nesta citação. Porém, com sua interrupção, não se diminui nem um pouco a importância de uma manifestação como essa que havia atravessado diversos séculos. Embora hoje não haja visita a presos na festa de São Luiz do Paraitinga - aliás, nem cadeia há mais na cidade - o aspecto da solidariedade sempre está muito presente em diversos momentos da festa, como no recolhimento das prendas e nos discursos do clero e da população na celebração das novenas. ${ }^{204}$ É a adaptação às situações contemporâneas, preservando a essência das manifestações.

\footnotetext{
201 Programa da Festa do Divino Espírito Santo da Parochia de São Luiz do Parahytinga, 1916, acervo pessoal de Benedita Antunes de Andrade. Vide programa na íntegra nos anexos II e III no fim da dissertação.

202 A maioria de seus textos foi reunida pelo próprio autor em uma brochura denominada São Luis do Paraitinga (usos e costumes) - separata da Revista o Arquivo, vol. CXXI. Departamento de Cultura, São Paulo, 1949.

${ }^{203}$ AGUIAR, Mário. Semanário de Taubaté, edição 85, junho de 1948 - Hemeroteca de Taubaté, setor jornais e semanários, caixa 87.

${ }^{204}$ Chama a atenção como a participação popular nas novenas que antecedem o grande dia da festa do Divino no Espírito Santo é muito mais intensa que no dia-a-dia das celebrações da Igreja local.
} 
Segundo João José Reis ${ }^{205}$, o papel de associação corporativa das irmandades acabava fundando sua ação solidária sobre as estruturas hierárquicas da sociedade desigual européia e ainda mais fortemente na sociedade colonial brasileira. Acredito que muito do motivo de a organização das festas do Divino ter passado às irmandades não seria questão específica ao aspecto de solidariedade. E sim porque elas eram as principais organizações corporativas com estruturas que permitiam a montagem de festas grandiosas como tradicionalmente foram as do Divino. Além do que, sabemos que no Brasil colonial a Igreja Católica não dispunha de um número suficiente de agentes eclesiásticos para atender ao imenso território brasileiro, cabendo, em grande parte aquelas pessoas próximas ao clero, uma função adicional da propagação da mensagem católica. As próprias irmandades acabavam desempenhando este papel.

Muitas delas tornaram-se extremamente poderosas, com membros integrantes dos principais escalões da elite colonial. João José Reis aponta como a principal as Santas Casas de Misericórdia, controladoras na Bahia e em diversas regiões do país de redes de hospitais filantrópicos, orfanatos, cemitérios e receptora de doações de uma forma geral. Veremos na descrição abaixo o quanto essa associação era ligada à nobreza, mas, abria exceções à participação popular também:

“ O compromisso de 1618 da Misericórdia de Lisboa, que regia a da Bahia, estabelecia que seus membros fossem alfabetizados e 'abastados de fazenda', proibindo expressamente a entrada de trabalhadores manuais. Seus membros se dividiam em nobres ou irmãos maiores - os aristocratas portugueses titulados ou nossos fidalgos sem título (senhores de engenho, grandes negociantes, altos funcionários) e oficiais ou irmãos menores aqueles que prosperam nas profissões 'mecânicas' (ourives, por exemplo),206

É interessante ressaltar o papel da rainha católica portuguesa Isabel de Castela (1470-1498) como a principal transformadora da festa na acepção de ação solidária, agora, ligada às irmandades e atingindo um grau de popularização ainda não visto antes. Conta Judas Tadeu de Campos:

“À sua devoção para o Divino Espírito Santo é atribuída não somente o costume da popularização da festa de Pentecostes, mas também a criação das

\footnotetext{
${ }^{205}$ Em seu livro A morte é uma festa: ritos fúnebres e revolta popular no Brasil do século XIX. São Paulo: Companhia das Letras, 1991.

${ }^{206}$ A.J.R.Russel-Wood. Fidalgos and philantropists (London, 1968) apud João José Reis, op cit, pág 51.
} 
Santa Casa de Misericórdia ( a misericórdia é um dos dons do Espírito Santo) que até meados do século XIX era a única instituição de atendimento social existente no Brasil". 207

Jaime de Almeida ${ }^{208}$ reforça essa tese ao contar que a Festa do Divino, no início do século seguinte à introdução por Isabel de Castela (1522 especificamente), já era realizada em Portugal com o principal objetivo social de angariar fundos que seriam empregados na manutenção de hospitais e outras obras de assistência domiciliar. Nessa mesma época, a festa já existia também nos Açores. Esse autor assim também reforça a tese de que tanto a festa de Portugal quanto a dos Açores transmitiram muito das características encontradas nas festas brasileiras desde a época colonial. Posso dizer agora, com toda a certeza, que a história da festa do Divino de São Luiz do Paraitinga mantém claramente perceptível toda uma identidade relacionada às manifestações ibéricas, corroborando totalmente a tese desses autores e visível a qualquer pessoa que a acompanhe. Contudo, não devemos esquecer que estamos falando de um modelo, já que as festas brasileiras possuem uma identidade própria, com a adição de singularidades locais, como veremos no caso de Paraitinga. ${ }^{209}$

\section{3 - A história da Festa do Divino em São Luiz do Paraitinga}

No Brasil, é consenso que já no período colonial as festas religiosas tenham tido grande destaque em todo o território. Desde o início da colonização, há de se imaginar a constante referência ao Divino, afinal, vimos o quanto essa comemoração havia se propagado em continente europeu. Já encontramos uma referência feita pelo papa Urbano VIII a um dia de guarda específico ao Divino, datando do início do século XVII e transferido, naturalmente, à colônia lusa:

\footnotetext{
207 Judas Tadeu de Campos, op cit, página 23-24.

208 Jaime ALMEIDA op cit, pg 538.

209 É só pensar na argumentação do filósofo Mário Perniola que propõe o termo "simulacro" para expor o processo em que a repetição de padrões inspiradores permite a libertação de um modelo original e a criação de algo autêntico. Afinal, os atores são outros, o espaço é diferenciado, as crenças são diversas, a situação é singular como um todo. Ver PERNIOLA, Mário. Pensando o ritual: sexualidade, morte e mundo. São Paulo: Estúdio Nobel, 2000 apud Rita de Cássia da Silva, op cit pg.6.
} 
" De fato, tal como um primeiro levantamento do calendário da vida colonial revela, (...) desde a fixação dos dias santos de guarda e santificados por Urbano VIII (papa de 1623 a 1644), deviam ser respeitados o Natal, a Circuncisão, a Ressurreição e suas oitavas, a Ascenção, o Espírito Santo e suas oitavas...". ${ }^{210}$

Embora a missão colonizadora portuguesa tenha apresentado um caráter altamente impositor de sua cultura, sabemos dos limites deste controle. Na colônia foi se criando uma cultura religiosa própria, com padrões altamente isentos do controle total pregado pela metrópole. Permitia-se à população brasileira, então em formação, a constituição de práticas culturais particulares, pois, mesmo muito pautada nas tradições lusas, a rica cultura local proporcionava a criação de uma "nova" festa, desde os primeiros tempos da colônia.

Como foi discutido no primeiro capítulo deste trabalho, é imensa a importância das festas religiosas no que diz respeito à participação popular na sociedade brasileira, inclusive nos dias atuais. Essa população acostumada a constantemente ser colocada como mero espectador das decisões das minorias ligadas ao círculo de poder, vislumbra então uma possibilidade de participar ativamente das festividades. Dentro de uma festa invertem-se posições sociais, a rua ganha protagonismo e, mesmo sabendo de todas as iniciativas de controle, constituise um palco privilegiado de interação social.

A própria história de São Luiz do Paraitinga coloca vários exemplos nesse sentido. Mesmo que alguns digam que quando grupos de escravos tinham a possibilidade de apresentar suas danças nas festividades do Divino, estas ocasiões eram apenas exceções paliativas daquela sociedade altamente exploradora. Acredito serem aqueles um dos únicos momentos em que esses sujeitos explorados podiam vislumbrar uma função social aglutinadora e incentivadora, organizando-se e tomando em suas próprias mãos a direção dos seus atos. Afinal, em um cotidiano tão difícil, as festas eram uma espécie de "válvula de escape". Mas eram também a condição fundamental de afirmação de simbologias e dogmas religiosos em um ambiente opressor, fortalecendo, pela característica de resistência, a cultura dos oprimidos.

${ }^{210}$ TINHORÃO, José Ramos. As festas no Brasil Colonial. São Paulo, editora 34, 2000, páginas 8-9. 
Desta maneira, mesmo que a Festa do Divino sempre tenha sido organizada por grupos de elite, é na participação popular maciça que temos sua identidade. Mais uma vez, achar que, atualmente, ao tomar contato com a cultura globalizada, a cultura popular corre sério risco de desaparecimento é simplificar a questão, afinal, ela sempre esteve contraposta aos desafios mais diversos e sempre mostrou, apesar das dificuldades serem realmente imensas, o seu dinamismo, capacidade de transformação, miscigenação e autonomia.

Voltando ao histórico da Festa do Divino em nosso país, as primeiras referências documentais sobre sua realização que localizei datam de 1738, na Freguesia de Nossa Senhora de Nazaré da Cachoeira, em Minas Gerais ${ }^{211}$; de 1765, quando foi introduzida por ilhéus lusitanos, na Matriz de Santo Antonio de Além do Carmo da Bahia ${ }^{212}$; e de 1761, no livro tombo de Guaratinguetá, no vale do Paraíba paulista, a cerca de cem quilômetros de São Luiz do Paraitinga. ${ }^{213}$

Chama a atenção que todos esses documentos já citam as festividades do Divino fazendo referências a situações pontuais, demonstrando que as comemorações já existiam em anos anteriores. No caso de Nossa Senhora de Nazaré de Cachoeira, a questão colocada pela documentação é a existência de vários agentes eclesiásticos desfilando pelas mas com instrumentos musicais e, de forma ainda mais escandalizadora, havia a presença de uma "crioula forra, de Ouro Preto, vestida de homem, cantando o Arromba e outras modas" ${ }^{, 14}$ no mesmo carro que eles. Uma situação escandalizadora para a sociedade de então e que ocorre dentro de uma festa do Divino, aparentemente, já consolidada. Não há nenhum aspecto no relato que realçasse o acontecimento de uma nova festa. Ela é apenas o espaço, por isso digo já consolidada, de um acontecimento surpreendente: o clero desempenhando função musical popular e, ainda por cima, acompanhado por uma ex-escrava na formação da banda.

\footnotetext{
${ }^{211}$ Francisco Vidal Luma e Iraci Del Nero da Costa baseados em documentação da Cúria de Mariana-MG apud TINHORAO, José Ramos, op cit, pg 138.

212 ARAUJO, Alceu Maynard, op cit, pág 27.

213 Referência de Alceu Maynard (idem anterior). Tive oportunidade de consultar pessoalmente o documento fotocopiado na Hemeroteca de Taubaté - caixa 33 (documentos oficiais de Guaratinguetá 1750-1780). Logo a seguir, no corpo do texto, transcreverei um trecho da documentação, contudo, adotando na quase totalidade a seleção já feita pelo ilustre autor.

${ }^{214}$ LUNA, Francisco Vidal; COSTA, Iraci del Nero. Minas Colonial: economia e sociedade. São Paulo: Fipe: Pioneira, s/d [1973]. Página 62.
} 
Como característica das festas populares, a preocupação com os registros escritos dificilmente surge como preponderante, e é de se imaginar a existência da festa do Divino em períodos bastante anteriores. Câmara Cascudo, inclusive, mesmo não encontrando as ditas documentações escritas para se basear, acredita na origem destas festas no Brasil já no século XVI, concomitante à chegada dos portugueses. ${ }^{215}$

Um documento que mostra a existência dessa prática no interior das naus portuguesas no mesmo século XVI apontado por Cascudo corrobora a perspectiva do culto ao Divino ser simultâneo ao início da ocupação brasileira. Trata-se de uma carta - transcrita por Paulo Miceli - datada de 1561, tendo sido escrita pelo jesuíta Gonçalo Rodrigues, a bordo de um navio para a Índia. As inúmeras viagens ligando Portugal à África e ao Brasil, nessa época, são marcadas por muitos registros parecidos ao escrito por Gonçalo Rodrigues. Antes, ainda na cronologia da comemoração ao Espírito Santo, vale lembrar a institucionalização da data pelo papa Urbano VIII como mencionado acima, ficando claro que esse ato tratou apenas de formalizar o calendário litúrgico, pois a comemoração ao Divino teve origem, como vimos, em comemorações européias bastante anteriores:

“ Dia do Espírito Santo se fez muito solene em nossa nau, porque costumam por honra de tal dia eleger imperador na nau, ao qual servem todos, capitão e os demais, por todo aquele dia. (...) Assim também, cumprindo o meu ofício, tive de coroar o imperador, porque o capitão dizia que aquilo se fazia para engrandecer a festa do Espírito Santo e por devoção, e assim não havia que recusar. Depois de dizer missa cantada fiz prédica ao imperador (...) deuse mesa franca a toda gente da nau, a qual estava vestida de festa, como na corte de sua majestade ". ${ }^{216}$

Gostaria que atentássemos também, além da questão cronológica proposta, para uma situação simbólica fundamental: a citação da figura do Imperador do Divino. Presente ainda hoje na maioria das festas do Divino - inclusive de São Luiz - e que retomarei à frente neste trabalho, o imperador, como é citado no documento, é tradicionalmente escolhido pela comunidade como um todo e exerce um papel preponderante de representatividade e poder no interior da festa. Percebemos, inclusive, no documento apresentado, o comandante do barco se colocar um dia todo ao serviço do imperador escolhido.

\footnotetext{
${ }^{215}$ CASCUDO, Luis da Câmara. Dicionário do Folclore Brasieiro. 10ª edição. São Paulo: Global, 2001.

${ }^{216}$ Carta de 1561 do Jesuíta Gonçalo Rodrigues apud MICELI, Paulo. O ponto onde estamos: viagens e viajantes na história da expansão da conquista. (Portugal séculos XV e XVI). São Paulo, Editora Página Aberta, 1994. páginas 172-173.
} 
O Imperador do Divino manteve por muito tempo em sua figura no interior das festas as simbologias do poder régio - sempre acompanhado pelo cetro e pela coroa - sendo, para muitos estudiosos, fundamental para o fortalecimento do sistema político, embora o discurso oficial sempre afirmasse o poder divino do Espírito Santo que estaria representado em sua simbologia. ${ }^{217}$

Martha Abreu reafirma o papel da manutenção de uma corte imperial nas festas do Divino como a principal característica de uma espécie de transmissão da realidade portuguesa e européia, de uma forma geral, para a América. Junto desse fortalecimento do poder político do governo imperial, rituais como a existência da casa do Imperador, da sua coroação, da distribuição de alimentos aos mais pobres, entre muitos outros exemplos, implantam e fortalecem a imagem ritualística a que estavam acostumados os colonizadores. ${ }^{218}$

Nas grandiosas festas do Divino do Rio de Janeiro, no início do século XIX, o Império é um local já muito estruturado e, apontando a imponência que estas comemorações buscavam alcançar, transformava o imperador do Divino em uma verdadeira continuidade da monarquia de Bragança, com todos os símbolos que poderiam estar reforçando sua imagem, reafirmadora do poder monárquico sobre a população. $^{219}$ Ao mesmo tempo, em sua outra face, nunca podemos esquecer da importância dessa manifestação, da qual participavam todos os grupos sociais, para a sociedade brasileira como um todo. O desenrolar da festa, contando com a participação dos diversos segmentos populares - "o povo real, pobre, negro e multiétnico, ${ }^{, 20}$ - acabava constituindo-se em um momento de exceção importante de inserção deste grupo tão excluído naquela sociedade, sempre numa relação paradoxal entre tentativas de controle pela elite e a independência assumida pelos populares.

A festa sempre tentava estabelecer de maneira bem clara o lugar da corte e seu espaço diferenciado - império, cetro, coroa e vários outros símbolos ligados à

\footnotetext{
217 Além do Imperador, a festa monta toda a estrutura de uma corte imperial, com a casa do Império local onde fica a bandeira principal da Festa - e a escolha de uma corte que acompanhará o Imperador. No caso de São Luiz do Paraitinga, é a corte imperial que carregará na principal procissão as bandeiras com os sete dons do Espírito Santo. Agora, o mais importante é a simbologia do poder que carregam, a perceber o luxo e importância das vestimentas de toda a corte, com natural destaque ao imperador.

218 Ver Martha Abreu, op cit, página 41.

${ }^{219}$ Iara Lis Carvalho apud Martha ABREU, op cit, pg 64.

${ }^{220}$ Ibid pg 64.
} 
realeza mostram isso - mas, o seu desenrolar não conseguia tirar o espaço também de reafirmação daqueles que não gozavam dos poderes ali representados. Ao constatarmos que ainda hoje o cargo de festeiro está intimamente relacionado ao status social, percebemos uma realidade com características semelhantes às do começo do século XIX - e, provavelmente, de antes.

É importante pensar na possibilidade de incorporação por parte da realeza daquela festa mais representativa da cultura popular buscando a legitimação e até mesmo um controle mais restrito de algo que lhe escapava. Uma festa com variados elementos de origem pagã poderia incitar, ao que parece, componentes de contestação à ordem vigente, justamente num momento de fragilidade do poder no decorrer das festividades.

De qualquer forma, tratava-se, como ainda acontece, de um sistema muito maior de trocas culturais que uma simples oposição aparente entre elite e subalternos. Usando esse exemplo da simbologia da realeza dentro da festa popular, Câmara Cascudo chega a afirmar o seguinte - na minha opinião até radicalizando a preponderância da cultura numa decisão política ${ }^{221}$ - sobre o papel exercido pelo Imperador do Divino e a correspondência disso na história política do país:

"O título de Imperador do Brasil foi escolhido, em 1822, pelo ministro José Bonifácio de Andrade e Silva, porque o povo estava mais habituado com o nome de Imperador (do Divino), do que com o nome de Rei". ${ }^{222}$

Embora tenha sido originalmente um cargo ocupado por adultos, passou a ser representado, na maioria das cidades, por uma criança, sempre mantendo um grande destaque dentro das festividades e adicionando representações de pureza, idoneidade, típicas das crianças, e de um cargo com insígnias praticamente sagradas. O próprio papel exercido por uma criança no cargo de imperador faz-me lembrar da simbologia exercida ainda hoje na mentalidade do po vo brasileiro, do papel de Dom Pedro II, tão jovem à frente de um cargo de tamanha importância. É uma marca

\footnotetext{
${ }^{221}$ Ou talvez a importância da cultura popular nas decisões políticas sejam maiores do que imaginamos mesmo.

${ }^{222}$ CASCUDO, Luis da Câmara apud ARAUJO, Ana Maria Ramalho Câmara de. A Festa do Divino e suas transformações na comunicação e na cultura. Dissertação de mestrado, PUC/SP, São Paulo, 2003, página 17.
} 
presente na memória coletiva, transfigurada em uma nova situação, e criadora de uma nova tradição.

Pela ótica de contestação social - sempre presente nas festas - a simbologia da criança no papel de imperador pode representar uma interpretação exatamente contrária à discutida anteriormente sobre a sacralidade do poder representado por um ente infantil. A criança pode também representar uma espécie de paródia da função de um imperador, afinal representa por um lado a pureza e docilidade, mas pelo outro a fragilidade e imaturidade.

Quanto à origem da festa em São Luiz do Paraitinga, a mais remota referência documental encontrada é um documento oficial da Câmara Municipal de 1803, denunciando o crescimento da prostituição na cidade. É uma situação semelhante à dos casos anteriores, quando uma questão pontual, sobre um assunto qualquer, aponta para a existência de uma festa já consolidada:

"Vinda de outras vilas, as prostitutas estão prejudicando a lavoura, atraindo à vila os homens que passam a noite com elas 'publicamente, no lugar do Império, em que se costuma festejar o Divino Espírito Santo". 223

Cita-se nitidamente um local estabelecido para o Império e, de forma ainda mais clara, uma tradição das comemorações, pois, afinal, era um local onde se tinha o costume de festejar o Divino - lembrando ser uma construção que permaneceria para além do momento da festa. Fica correlata a preocupação com a libertinagem, ainda mais, frente a um local tão sagrado como o Império do Divino.

Pouco tempo depois, em 1809, a Câmara dos Vereadores de São Luiz do Paraitinga autoriza o "mui respeitoso festeiro da santidade do Espírito Santo, agricultor, seo Antonio dos Santos, a erigir uma casa para as funções do Divino"224. Não esquecendo tratar-se de uma época de muitas dificuldades materiais, ainda mais em um município pobre como São Luiz do Paraitinga, seria necessária uma festa grandiosa para o dispêndio da construção de uma nova edificação. Algo que foi

\footnotetext{
${ }^{223}$ DAESP. Ordenanças. $\mathrm{N}^{\circ}$ de ordem 288, caixa $\mathrm{n}^{\circ} .59$, doc. 59-2-15 de 30/12/1803 apud Jaime de ALMEIDA op. cit pg: 534-535.

${ }^{224}$ Documento denominado Vereanças (1800-1814) do Arquivo da Câmara Municipal de São Luiz do Paraitinga, folha 141-142 de 16/04/1809 citado por Jaime de Almeida e hoje depositado no Arquivo do Estado de São Paulo, caixa no 59 (Ordenanças e Atas da Câmara Municipal de São Luiz do Paraitinga).
} 
possível, afinal, a autorização da vereança não cita contribuição financeira alguma além da proporcionada pela própria festa.

Embora em 1836 o tenente Tomás Gomes França solicite a essa mesma Câmara Municipal a derrubada desta casa do Império, enfim, esta estaria colocando em risco a sua própria moradia pela possibilidade de desabamento, percebemos a concretização do projeto de 1809 e a sua manutenção, no mínimo, por vinte e cinco anos. E é bem provável que outro local tenha sido construído ou adaptado para substituí-lo haja vista a importância do Império dentro das festividades do Divino. ${ }^{225}$

Acredito que podemos recuar ainda mais na cronologia do início das comemorações em louvor ao Divino na cidade de São Luiz do Paraitinga, lembrando inclusive que a festa já era realizada antes dessas datas a que venho me referindo. Práticas diversas, representativas da crença dessas pessoas no Espírito Santo, ou mesmo em rituais pagãos, cujos símbolos acabaram incorporados pela festa posteriormente, existem de longa data.

Mas falo em recuar um pouco mais na história da festa do Divino luizense, cruzando dois documentos locais que não revelam a existência da festa em São Luiz do Paraitinga de forma explícita, mas contribuíram imensamente para que esta surgisse. O primeiro é a prova documental da existência da festa já em 1761 em uma cidade bastante próxima, Guaratinguetá. Seja pelos caminhos do ouro, anteriores à fundação da cidade luizense, ou mesmo o trânsito da produção cafeeira posterior, as regiões de São Luiz do Paraitinga e de Guaratinguetá sempre estiveram ligadas, com relações comerciais favorecendo essa aproximação. O que favorecia, naturalmente, as trocas culturais.

Um dos elos da aproximação entre São Luiz do Paraitinga e Guaratinguetá é o próprio fundador da cidade, Manuel Antonio de Carvalho, que assina o documento de petição da possibilidade de fundar uma nova povoação em 1768 dirigido ao então governador da província, o Morgado de Matheus, se intitulando "sargento-mór Manoel Antonio de Carvalho, juiz das demarcações de Guaratinguetá" 226 . A festa do Divino, pela sua grandiosidade histórica no Brasil colonial, provavelmente congregaria gente de toda a região de Guaratinguetá e, entre

225 Atas da Câmara Municipal de São Luiz do Paraitinga (1829-1839), sessão de 04/11/1836 apud ALMEIDA, Jaime, op cit, pg 536 e 578.

${ }^{226}$ Departamento do Arquivo do Estado de São Paulo, Ofícios das Câmaras/ São Luiz do Paraitinga, 1721/1822 caixa 7, ord.233, pasta 3, despacho de 02 de maio de 1769. 
essas pessoas, com certeza estavam muitos dos futuros moradores da região da atual São Luiz do Paraitinga

Na própria petição ao Morgado de Matheus, Manoel Antonio de Carvalho já se coloca como responsável a levar pessoas para habitarem a nova localidade. A possibilidade maior seria a de convidar pessoas próximas a seu círculo de influência, ou seja, da região de Guaratinguetá. Transcrevo abaixo um trecho de um documento que permite a observação da questão do sagrado, além do fator cronológico do surgimento desta manifestação na região próxima a atual cidade de São Luiz do Paraitinga:

"Com bastante magoa e mayor sentem ${ }^{\circ}$ fui informado da grande irreverencia com que nesta Villa se trata a Imagem do Menino Deos na ocasiao da Festa do Espirito Santo, levando em um andor da Caza do Emperador para Egreja e aly ser coroado em lugar daquelle, indo nesta occaziao os homens cubertos, acrecendo mais deixarem por alguns dias a mesma Imagem do Deos na caza ou throno do Emperio que sendo sem decencia pela publicidade em que esta, e por isso exposta amayores irreverencias. E porque similhante abuso se deve desterrar das Catholicas ordens emando, que o Rmo. Vigário desta Egreja não consinta que daqui em diante se faça simelhante funcção com a Imagem do Menino Deos - sob pena de excomunhão mayor e pagamento de coincoenta cruzados". 227

Novamente a citação se refere a uma festa que provavelmente já ocorria anteriormente em Guaratinguetá. Agora chama a atenção, e daí o segundo documento que anunciei, que, na continuação desse primeiro documento referente à festa de Guaratinguetá se denomine até mesmo o citado vigário: "Rvmo. Thimotheo Correa" ${ }^{228}$. O mesmo que vem à então vila de São Luiz do Paraitinga benzer a primeira capela construída no local ${ }^{229}$ :

" no dia 03 de abril de 1773 foi designado uma provisão pela qual o vigário de Guaratinguetá, cuja Comarca eclesiástica pertencia esta Villa de São Luiz, foi autorizado a benzer a primeira Capela construída pelo povoador Manoel Antonio de Carvalho. Sendo que, no dia 12 de maio do mesmo ano o

\footnotetext{
${ }^{227}$ Livro Tombo da Matriz de Guaratinguetá. Hemeroteca de Taubaté - caixa 33 (documentos oficiais de Guaratinguetá - 1750-1780), folha número 5. Ver também Araújo, Alceu Maynard, op cit, pág 27.

${ }^{228}$ Idem anterior, folha número 7.

${ }^{229}$ A construção de uma capela quando estudamos a realização das festas do Divino é muito importante se pensarmos ser muito pouco provável a possibilidade de uma festa sem a existência de uma capela e de um padre rezando as missas.
} 
licenciado Thimotheo Alves de Correa Benzeu a Capella e o Cruzeiro, e em seguida celebrou pela primeira vez o santo sacrifício da Missa"230

Não dá para afirmar apenas pelo trânsito dessas pessoas específicas entre esses dois municípios que a festa tivesse sido efetivamente implantada em São Luiz do Paraitinga nessa época. De qualquer forma, desde então, os comentários e as simbologias relacionadas a ela estão circulando por toda a região e, acredito ser esta a questão crucial.

\section{4 - A festa do Divino Espírito Santo de São Luiz do Paraitinga como ponto de sociabilidade primordial no município}

Com mais de dois séculos de existência em São Luiz do Paraitinga - apesar de uma grande interrupção das manifestações profanas no início do século XX de que tratarei adiante -, a festa do Divino luizense continua a ser realizada, mantendo uma identidade aglutinadora, por meio da cultura popular, para uma grande parcela de sua população. Mantêm-se, juntamente, as tradições de conflito entre a Igreja e esse "catolicismo tradicional", reafirmando-se os limites impostos por alguns grupos sociais que organizam as festividades, porém, nunca imunes à participação e influência das camadas populares. Assim, nada impede que o próprio povo, apesar da força de segmentos sociais poderosos, faça ainda hoje a eleição do seu Rei Congo. Que o próprio festeiro, geralmente um membro da elite local, tenha que interagir com os interesses da maioria da população nos momentos de decisão dos eventos desta, cedendo na maioria dos casos. Ou ainda, que a apresentação de grupos folclóricos, como uma congada, possa inverter funções sociais, colocando em destaque personagens desprovidos de status social, constituindo um momento de excepcionalidade no cotidiano de muitas pessoas e da cidade como um todo.

O casal Bento Claro Pereira, de 82 anos, e sua mulher Teresinha Clara de Jesus, de 74 anos, há mais de 20 anos recebe a folia com uma tradicional janta para os foliões. Hoje, moradores do bairro do Alto do Cruzeiro, na cidade, viveram a

\footnotetext{
${ }^{230}$ Ribeiro, 1904, 05 apud TOLEDO, Marcelo Henrique Santos. Espaços individuais e coletivos de sacralidade nos meios populares. Um estudo sobre imagens, conflitos simbólicos e campo religioso. Mestrado Ciências da Religião, PUC/SP, 2001.
} 
maior parte da vida no bairro das Perobas - zona rural luizense - onde eram organizadas confraternizações para toda a vizinhança nas ocasiões em que a folia era recebida. Podemos perceber, a partir da experiência deste casal na atualidade, a força simbólica da relação ímpar com o Divino e a importância desta relação:

Fala primeiramente Dona Teresinha:

“ Bento, o 'menino’ está perguntando da importância de receber o Divino Espírito Santo aqui em casa... Imagina não... Não há benção maior pra nossa vida, não há orgulho maior pra nossa família iluminada por isso... É o principal santo da Igreja que vem aqui dentro de nossa casa tão pobrezinha, é o menino Jesus que vem atrás dos pobres né... Sempre o padre fala isso... Além do que a folia é uma coisa linda, uma belezura mesmo..."231

Continua, o já debilitado pela saúde, sr. Bento Claro Pereira, revelando, no entanto, muita lucidez na sua memória de 82 anos vividos junto da festa:

“É uma festa que lembro desde pequenininho... e é mais antiga viu 'moço', porque meu vô já era cargueiro do Divino. Ele sempre me contava de como andava a folia naquele tempo.... percorria toda a região, num tempo em que tinha os fazendeirão de café, a folia arrecadava uma quantidade imensa de prendas e era aquela fartura! (...) É por esse tipo de coisa que é um orgulho pra gente receber o santo e a comitiva dele na festa mais importante da cidade!" 232

Reforçando esse papel dinâmico das manifestações populares ${ }^{233}$, é inegável o quanto a festa do Divino foi se transformando na cidade desde a época da sua fundação até os dias atuais. Agora, o que chama muito a atenção, é o quanto se mantém o aspecto da independência da relação direta entre a população e o sagrado, entre as manifestações populares e o cotidiano. A devoção ao Espírito Santo é primordial à maior parte dos luizenses e para todos os que vêm para os dias da festa com intuito religioso. Mesmo vivendo hoje em um momento onde o catolicismo vem perdendo muita força de penetração, é um momento especial de religiosidade

\footnotetext{
${ }^{231}$ Entrevista com dona Teresinha Clara de Jesus, 74 anos, moradora do bairro do Alto do Cruzeiro de São Luiz do Paraitinga, em maio de 2007. Casada há 58 anos com Bento Claro Pereira, recebiam, no mesmo dia em que entrevistei-os, a reportagem do jornal "O Estado de São Paulo", ganhando destaque na futura reportagem, pelo fato de receber a folia em sua residência há mais de duas décadas ininterruptamente . Vide DEODATO, Livia "A cultura da fé na Folia do Divino". Caderno 2. Jornal O Estado de São Paulo, ano XXI, número 7.051, 14 de maio de 2007.

${ }^{232}$ Entrevista com o senhor Bento Claro Pereira em maio de 2007, vide nota anterior para mais informações.

${ }^{233}$ Temos que lembrar que não apenas as manifestações populares são dinâmicas, mas a cultura como um todo. Quem viu folclore como resquício estático do passado, pensava cultura como conjunto de características congeladas no momento.
} 
na vida das pessoas que se identificam pelo Divino Espírito Santo. E tudo isso independendo da participação destas mesmas pessoas no cumprimento cotidiano dos preceitos do catolicismo.

Muito da força da religiosidade popular é fruto de uma tradição consolidada em toda a história da cidade de São Luiz do Paraitinga. Documentos produzidos em data próxima à da fundação do município, reportagens da imprensa local em momento de destaque da festa no início do século $\mathrm{XX}$, documentos oficiais dos poderes públicos - em especial, os pedidos de licença de peregrinação apresentados à Câmara Municipal desde o início do séc. XIX - fornecem informações sobre a festa, e mais importante, são representativos do destaque que alcançava, modificando totalmente a rotina da cidade.

“Neste mesmo ano (1872), o vigário da freguesia de Lagoinha pergunta se deve enviar as quantias arrecadadas com licenças e multas das bandeiras do Espírito Santo para a Igreja Matriz de São Luiz (...) trata-se de 'matéria sagrada', afirma o vigário de Lagoinha. $\mathrm{O}$ sacerdote pode estar pensando na enchente que inundou a cidade de São Luiz do Paraitinga em dezembro de 1863. É voz corrente na região, que o rio Paraitinga saiu bruscamente de seu leito logo depois que o delegado de polícia prendeu um grupo de foliões do Divino que, tendo à frente o Alferes da Bandeira, esmolava pelas ruas da cidade sem a devida autorização. O edifício mais importante destruído foi justamente o da cadeia." 234

A festa pode não ter mais a penetração e até importância política que chegou a exercer no passado. Nem essa crença "exacerbada" no sagrado como no caso relatado por Jaime de Almeida da enchente de 1863. Entretanto, é ainda fundamental para a vida de toda a comunidade luizense, sendo centro de discussão em diversos momentos durante o ano e envolvendo pessoas das camadas mais diversas. Até podemos dizer que a juventude atual encontra-se cada vez menos participativa. Mas, seria uma inverdade qualquer afirmação no sentido de uma falência da importância da festa na vida da cidade em nossos dias.

\footnotetext{
${ }^{234}$ MOC- CMSLP. XVIII. F. Festas (1840-1903), docs de 13/04/ 1840, 3/01/1872 e 19/03/1872; Caderno de Juca Teles do Sertão, $n^{\circ}$ 30, p. 66. apud ALMEIDA, Jaime. Op cit, páginas 537 e 538. Esta documentação citada por Jaime de Almeida à época no museu onde fica a casa do Dr. Oswaldo Cruz, em São Luiz do Paraitinga, hoje, encontra-se disponível à consulta no Arquivo do Estado de São Paulo Departamento do Arquivo do Estado de São Paulo: Ofícios das Camaras/ São Luiz do Paraitinga, cx 7.
} 
Momentos da festa como o relatado pelo pesquisador Alceu Maynard, em 1947, e transcrito logo abaixo, mostram o quanto ela foi fundamental para as pessoas e crucial para a história da cidade. Mesmo tratando-se de um momento de grave crise econômica do município, sendo a festa visivelmente afetada por essa circunstância, Maynard não deixa de demonstrar sua impressão positiva sobre o evento. O trecho revela ainda a ligação da festa com as citadas festas pagãs européias e a quebra do calendário da Igreja Católica nessa comemoração:

“ Como poderá o devoto pagar as promessas antes da colheita, se elas foram feitas quando pediram ao Divino, representado na bandeira, uma boa safra, evitasse as intempéries, granizo, geada e até mau olhado, pagando pela proteção dispensada do ano agrícola com o bom resultado que colhesse? Tal festa tem mesmo que obedecer ao calendário agrícola. Este tem que se sobrepor ao religioso. (...) Em 1947 a festa do Divino foi realizada em São Luiz do Paraitinga de 19 a 24 de agosto, prevalecendo então o calendário agrícola. Foi sem dúvida uma bela festa, assim julgamos, embora nossa opinião tenha discordado de vários antigos moradores da 'Imperial cidade de São Luiz do Paraitinga'. O festeiro foi o próprio pároco Monsenhor Ignácio Gióia, há dezenas de anos pastor espiritual dali. (...) É justificável tal saudosismo. As atividades agrícolas vão cedendo lugar às pastoris; vai-se despovoando o município, e a própria folia do Divino, que voltava outrora farta de ofertas, hoje vem parca. Escasseou em relação ao passado."235

Quando nos deparamos com a festa em nossos dias, mesmo que combalida na "luta" frente aos padrões homogeneizantes da modernidade, usamos esses exemplos de resistência para constatar a força de algo muito consolidado, que sobrevive em momentos difíceis justamente pela força de suas raízes e simbologias. A história da festa acabou gerando uma identidade para esse grupo participante. Passam a partilhar simbologias que não há nem como simplesmente classificar como luizense, e sim como ligadas especificamente a uma forma própria de cultuar o Divino Espírito Santo. Tem-se uma confirmação da brilhante constatação de Carlo Ginzburg sobre a "circularidade cultural"236. Separadas por um oceano no espaço e por séculos de distância temporal, a riqueza da cultura popular descrita por Mikhail Bakhtin retomado por Ginzburg, acaba formando uma "concepção de mundo",

\footnotetext{
235 ARAÚJO, Alceu Maynard. Estudos de Folclore - Poranduba Paulista - Tomo I: Festa. Fundação Escola de Sociologia e Política de São Paulo, 1949. páginas 81, 82.

${ }^{236}$ Conceito básico na sustentação teórica desta pesquisa. Vide: GINZBURG, Carlo. Mitos, emblemas, sinais: morfologia e história. São Paulo: Companhia das Letras, 1989.
} 
genericamente falando, cujos valores estão diretamente ligados aos existentes na festa do Divino em Paraitinga.

Não poderia deixar de transcrever integralmente um poema do senhor Antonio Nicolau de Toledo de $1969^{237}$ chamado "Festa do Divino"238 e que sintetiza brilhantemente essa identidade que o luizense "comum" cria ao redor da festa e o clima de envolvimento que a mesma provoca. Serve também para já termos uma idéia mais clara dos eventos que a constituem e que venho citando aos poucos:

“São Luiz tem a festa do Divino

Com bandera e os fulião

Ela sai pros bairro

Fazeno a pedição

Essa festa é muito boa

É de grande tradição

Tem João Paulino e Maria Angu

Que é um baita bonecão

Eles sai pela cidade

Fazeno a distração

Corre atráis da molecada

E tamém dos marmanjão

As moça fica espiano

Só de dentro do portão

$\mathrm{E}$ as veia fica com medo

Pensano que é assombração

Depois lá no mercado

Eles fáis um fogãozão

Cozinha carne de vaca

Nuns tacho e nuns panelão

Depois de bem cozida

Já tá pronto o afogadão

Põe farinha de mandioca

Pra não dá indigestão
O Moçambique dança na rua

Ripicano os seus bastão

Amarra guizo nos pé

Pra dá a marcação

Toca viola, toca caxa

Fazeno a introdução

E os mestre canta verso

Da sua imaginação

Lá no campo a cavaiada

Fáis a sua izibição

Deis par de cada lado

De cavalo redomão

Em cada um desse cavalo

Vai montado um pião

Pois são tudo enfeitado

Com fita de gurgurão

Essa festa é afamada

Em toda nossa região

Na praça da matriz

Faiz barraca pro leilão

Toca banda, toca sino

Rebenta muito rojão

O padre celebra missa

E depois faiz procissão

${ }^{237}$ Seu Antonio Nicolau de Toledo, mais conhecido como Toninho do Bar, foi uma das pessoas mais influentes na vida cultural da cidade. Maestro da Corporação São Luiz de Toloza, era exímio contador de causos e histórias. Infelizmente faleceu em 2005. Seu funeral muito me marcou pela comoção da população perdendo um ente de destaque da vida cultural da cidade.

${ }^{238}$ Documento do arquivo pessoal do pesquisador Judas Tadeu de Campos e gentilmente cedido a es sa pesquisa. 
Na frente São Benedito

Atráis São Sebastião

Irmandade do Santíssimo

E o Sagrado Coração

Nossa Senhora Aparecida

A Imaculada Conceição

Mais atráis vai o Divino

E atráis dele a murtidão

De noite tem a jongada

Relembrano a escravidão

Ali acende uma foguera

Com pau de lenha dos bão

Dança preto, dança branco

Pois não existe distinção

Candogueiro fala fino

Fala grosso o tambusão

Os jonguero vão dançano

Com suas inguáia na mão

Vão fazeno os seus verso

Tirando da imaginação

Eles tem que ser bem feito

Não pode haver distração

Si canta verso errado

Atrapáia toda função

Nóis temo bom jonguero

Todos de arto padrão

Temos o Tico Armeida

O Batáia, o Chico Arão

Não podemos si esuqecê

Do Arcino e Pedro Adão

Também temos o Juviano

O Piãozinho e o Napoleão
Isso vai a noite inteira

Dano viva ao Pai João

Tamém dão viva a São Jorge

Que mato o grande dragão

Dão viva a São Benedito

Que é o Santo da devoção

E a fogueira vai queimano

Até os pau virá carvão

E aí a festa termina

Eles vão cumpri a obrigação

Vão todos prô serviço

Pra podê ganhá o pão

Pois tudo na vida tem fim

Tudo passa, tudo vão

Só fica a saudade

Pra nossa recordação 
Confesso ter ficado emocionado quando li esse poema pela primeira vez. Sua linguagem típica, a forma de se rimar típica do mundo popular, acabou me fazendo enxergar uma festa, com suas especificidades, cerca de quarenta anos atrás. Surgem muitos temas interessantes a partir dele e que retomarei em discussões à frente, com destaque para a importância do andor de São Benedito abrindo a procissão de uma festa originária da elite branca e de irmandades poderosas como do Santíssimo e do Sagrado Coração. O que tiro por ora como mais importante é a certeza do dinamismo e do poder transformador da participação popular na festa do Divino luizense. Mudam-se muitas manifestações - hoje por exemplo o jongo praticamente já desapareceu - entretanto, se tem uma confirmação da brilhante constatação de Carlo Ginzburg sobre a "circularidade cultural" referida acima.

Passo agora, finalizando esse capítulo, a uma discussão dos principais rituais da festa, pensando mais concretamente nas relações características constituintes desse mundo singular da cultura popular luizense do qual estamos falando. A festa, obviamente, tem se transformado em toda a sua história bicentenária na cidade. Desta forma, não é possível apenas descrever os eventos no momento do café ou do seu Antonio Nicolau de Toledo, como apontam os documentos analisados, e analisar a festa do Divino na atualidade. Selecionei, a partir destes documentos, situações que chamaram a atenção mos dias atuais e, justamente, por se relacionarem com momentos de destaque na história da festa - continuando a tradição ou modificandoa-, através dos caminhos que a própria pesquisa foi apontando.

\section{5 - A importância da folia na festa do Divino de São Luiz do Paraitinga}

Antes da festa se iniciar um grupo de pessoas tem um papel fundamental na realização da Festa: a Folia do Divino Espírito Santo. Durante muitos meses, os foliões percorrem os bairros rurais de São Luiz do Paraitinga e parte dos municípios vizinhos (Cunha, Taubaté, Lagoinha, Natividade da Serra, Redenção da Serra, entre outros) ${ }^{239}$. Sua função é arrecadar prendas (doações que financiarão a festa) e

\footnotetext{
${ }^{239}$ Vide o mapa do percurso costumeiro da folia luizense no anexo IV no fim da dissertação.
} 
convidar o povo para os festejos. Possui um forte caráter cerimonial destacando-se em suas apresentações a religiosidade tradicional e a devoção da população em seu papel evangelizador.

Como já dito, a festa do Divino possui um calendário cíclico, sendo apresentado no último dia da Festa o festeiro do próximo ano que logo se juntará à Folia do Divino, iniciando a peregrinação para arrecadar prendas para a festa seguinte. As Folias, originárias de Portugal, executavam inicialmente uma dança rápida e bem diferente da praticada hoje no culto ao Divino, persistente ainda tanto na Beira, no "Velho Continente", como adaptada e reinventada nas regiões mineiras e paulistas do Brasil. Uma diferença fundamental entre as folias européias e as brasileiras é a sua função de recolher prendas, típica da nossa cultura ${ }^{240}$.

Ao chegar a cada casa, a Folia cumpre um pequeno ritual, quase sempre semelhante: a dona da casa recebe a bandeira, oferece as fitas que pendem do mastro para que todos os membros da família beijem e, enquanto os foliões cantam, o dono da casa oferece a prenda. É comum que a dona da casa leve a bandeira ao interior dos cômodos para abençoar a casa, mostrando a força simbólica da bandeira do Divino.

Mostrando o impacto da simbologia da bandeira carregada pelas folias, Judas Tadeu de Campos a considera o centro das devoções da zona rural luizense ${ }^{241}$ E são várias as razões para essa afirmação. É ali, por exemplo, que se colocam os retratos de parentes como ex-votos de alguma graça alcançada. E durante a permanência numa casa, a bandeira - feita com pano vermelho, encimado por uma pomba prateada na ponta do mastro - fica sempre em lugar de honra. Passar a sua frente sem prestar as devidas homenagens, com certeza é uma atitude de desrespeito não apenas ao símbolo, mas, sobretudo, àquela comunidade identificada pelo culto ao Espírito Santo.

A folia do Divino é formada, normalmente, por quatro foliões; sendo dois tocadores de viola (mestre e contramestre), um de caixa de percussão (contralto) e

\footnotetext{
${ }^{240}$ Luís da Câmara Cascudo op cit, pg 242.

${ }^{241}$ CAMPOS, Judas Tadeu. A Festa do Divino e a cultura caipira de São Luiz do Paraitinga: decadência ou transição? Revista Ciências Humanas da Universidade de Taubaté, ano VI, volume 8, número 12, pgs: 52 a $58,1997$.
} 
outro, de triângulo (típi). São antecedidos pelo alferes que é quem conduz a bandeira e é, geralmente, o próprio festeiro, responsável também por toda parte administrativa da festa. Faz parte da folia ainda o carguereiro, cuja incumbência é recolher as prendas.

Esta folia incorpora um ritual que procura reforçar a crença no sagrado. Marcelo Toledo aponta também o papel simbólico exercido pela folia em todo o município luizense, sobretudo na zona rural, destacando a faceta característica da religiosidade tão tradicional que venho atribuindo às pessoas envolvidas na cultura popular luizense:

"Muitas das atitudes apresentadas pelos moradores dos bairros rurais é considerada pelo padre como ignorância e superstição, uma deformação da religião. As dificuldades que esses moradores têm em manter contato com a cidade, em se guardando as devidas proporções, os liberam da orientação rigorosa e diretiva do agente eclesiástico. Neste caso, observa-se então que as folias rurais, conservam muito de sua estrutura ritualística original, que consiste em: cantorias, orações, beijamentos, peregrinações..."242

Entretanto, não se pode esquecer que a folia do Divino, atualmente, nem sempre tem conseguido percorrer todo o tempo que antecede a festa com sua formação completa. Alegando dificuldades financeiras para manter um grupo de pessoas fora de seus afazeres por um longo tempo, tem sido comum, nas últimas festas, a bandeira percorrer o município e seus arredores só com o festeiro ou representantes da Igreja. A própria manutenção de um grupo fixo de foliões já não ocorre mais, com pessoas muitas vezes desligadas do município, fazendo funções importantes dentro de suas apresentações.

Nem por isso suas apresentações deixam de constituir um evento extremamente simbólico na vida das pessoas ligadas à festa do Divino e, confesso ser uma grande dificuldade para mim, transformar em discussão acadêmica um ritual tão simbólico, onde olhares, interação coletiva, expressividade, dão a tônica da situação.

Quando a folia visita uma residência, torna-se muito claro toda essa efervescência do dinamismo da cultura popular. Os cantos da folia se adaptam à

${ }^{242}$ Marcelo Henrique Santos TOLEDO op cit, pág: 20. 
situação e ao momento específico da peregrinação. Há um canto para a entrada; um, para pedir a prenda ou uma promessa específica; outro, para agradecer. $\mathrm{O}$ fato da comunidade se reunir, motivada pela identificação de símbolos comuns, faz os cantos das folias serem fundamentais à existência da festa como um todo. Afinal, estas pessoas participantes da festa se identificam entre si a partir deste espírito coletivo demonstrado em situações como as visitas da folia.

Sugiro então que se ouça um canto da folia do Divino de São Luiz do Paraitinga, um registro de 1984 , da folia mais tradicional da cidade, regida então pelo mestre Dito Geraldo, e que transcrevi com o auxílio de um dos integrantes da principal folia do Divino em atividade atualmente em São Luiz do Paraitinga, sr. Rafael Mendonça. Este senhor era o contramestre dessa folia tendo, infelizmente, falecido pouco tempo depois de feita a transcrição, datada de $2006 .{ }^{243}$

\section{Trecho do Canto Folia do Divino de São Luiz do Paraitinga- mestre Dito Geraldo Registro de 1984 recolhido por Benedito Galvão Frade Junior Transcrição feita em conjunto com o contramestre, sr. Rafael de Mendonça (2006)}

O Divino ai já vai perdoar

É o vosso Pai tão poderoso

Aiele deixa a santa a santa benção

Nói agradece aos céus o conforto É...

Deus lhe pague arroz e feijão

Ai que vós deram pra companhia

Espírito Santo é quem abençoa

Ao meu Senhor e sua família

É...

Deus lhe pague a Santa Ceia

Em santa mesa a todos abençoai

Espírito Santo é quem abençoa

A sua casa ter a fartura

É...

\footnotetext{
243 A reprodução do canto da folia está gravada na faixa 01 do CD que acompanha este trabalho (anexo I). O trecho analisado dura oito minutos e trinta segundos. Não podemos nunca esquecer do quanto o contexto onde é apresentado um canto como esse é fundamental ao seu entendimento, ficando prejudicada sua audição descontextualizada de suas simbologias. O curso do prof. dr. José Geraldo Vinci de Moraes "História, memória e música popular: dilemas, impasses e possibilidades de construção do conhecimento histórico" - oferecido no $1^{\circ}$ semestre de 2006 no programa de pós graduação em História Social da Universidade de São Paulo - foi fundamental no embasamento teórico, permitindo a transposição da expressividade da musicalidade deste grupo, algo tão distante a priori, do corpo do texto de uma dissertação teórica.
} 
O Divino que vai se embora

É o nosso Pai, o Pai-da-guia

Ai que pagou sua promessa

Aido senhor e de sua família

É...

Neste canto da Folia do Divino se percebe daramente uma confirmação daquela estrutura mnemônica, característica de grupos assentados em tradições orais, anunciada no primeiro capítulo deste trabalho a partir dos textos de Eric Havelock. Podemos perceber que temas como o Espírito Santo, o Divino, o Pai são sempre retomados e marcam o canto dando a identidade dessa representação.

É sempre importante lembrar que esse é apenas um canto de agradecimento, executado após o jantar dos membros da folia. Como adiantei, são vários os cantos durante o ritual e, de forma surpreendente - para nós -, não há nenhum registro escrito que baseie os foliões. A tônica destas apresentações é essa estrutura mnemônica que usa a repetição de temas - incluindo melódicos - como forma de memorização.

No ritual é sempre o mestre quem inicia as frases e seus companheiros já a terminam cantando junto, pois, afinal, são frases "comuns". É o repertório lingüístico destas pessoas que está acompanhando a execução do canto utilizado geralmente uma população muito simples. Buscando-se uma maior interação com o público, já a própria letra do canto remete muitas vezes, embora não nesse caso, ao nome do dono da casa, a pessoas influentes na comunidade, reforçando laços de identidade de grupo e memória coletiva.

Há uma estrutura de discurso muito mais próxima da maneira como se fala, não havendo preocupação com regras gramaticais, nem com uma estrutura uniforme no texto. A questão melódica é também marcada por essa representação da fala dos foliões. E para mim, aqui fica claro, como, nesse caso, uma análise musical pautada por padrões eruditos diminuiria o seu sentido. Tanto a melodia como a harmonia podem até ser consideradas muito simples tecnicamente falando e, nem por isso, esse canto deixa de demonstrar um caráter extremamente persuasivo na comunidade onde ele é tocado, mostrando assim sua importantíssima função social, muito além da estrita análise musical. 
Dessa forma, não há sentido algum em buscar uma análise musical sem a correspondência que esta mesma música possui na vida das pessoas. Ou seja, não há significado em se aproximar de uma manifestação na qual a musicalidade é tão forte, fazendo uma discussão eminentemente acadêmica, pautada em conceitos sociológicos, antropológicos, históricos, sem discutir conceitos musicais, da mesma forma que fazer isso sem correspondência nas mesmas discussões sociológicas, antropológicas e históricas inviabiliza uma análise mais completa.

A idéia de Eric Havelock a que me referi no primeiro capítulo, quando este diz que o reforço de métrica verbal casado com melodias e ritmos de dança típicos são marcantes das culturas orais, é facilmente identificada m canto citado. Os tocadores de viola e da caixa de percussão acabam criando uma atmosfera de devoção e de muito respeito a todos os presentes através da melodia. E os símbolos, que são a razão de uma apresentação como essa, com todo o destaque à bandeira do Divino, parecem que ganham uma função ainda mais básica tanto pelo lugar de destaque que ocupam na apresentação, como pela sua valorização reforçada pela letra da canção.

É incrível como ainda é forte a interação entre o público de cantadores em uma apresentação como essa. A folia também faz uso de recursos expressivos como pessoas vestidas de palhaço - e dramáticos - como momentos do canto e da melodia em que se expressa bastante sentimentalidade. A gravação provavelmente era presenciada por muitas pessoas - como sempre acontece nos pousos de folia - e não ouvimos nesse registro nem um ruído que não fosse o dos cantadores da folia. Nos momentos em que o canto atinge formas mais agudas, ou, no intervalo entre as falas em que a percussão é a marca do instante, expressam uma dramaticidade muito grande.

Sintetizando essa análise, esse canto da folia luizense representa uma espécie de fusão desses tantos aspectos que estamos reafirmando como marcas identitárias das camadas populares: a força de perpetuação, penetração e representatividade exercida por quaisquer eventos assentados na oralidade, inclusive nos dias atuais; a forma de entoar específica e extremamente expressiva e religiosa; a característica primordial das culturas orais de uma total inexistência de hierarquias durante o 
canto, todos são iguais dentro do ritual; um processo de criação complexo e adaptado às relações sociais do momento, poporcionado pela constituição dessa memória seletiva e intimamente ligada à visão de mundo particular dos "populares". Esses eventos dramáticos, sempre envolvendo a coletividade, são os fatores primordiais dessas verdadeiras "catarses culturais" proporcionadas pelas manifestações populares.

Não acredito ser capaz de propor uma análise mais representativa que a própria fala do mestre da folia de Reis de São Luiz do Paraitinga, José de Arimatéia, quando pedi que me explicasse um pouco sobre este canto que lhe é tão mais familiar. Mesmo líder de uma folia de Reis, ele muitas vezes acompanha as folias do Divino. Sua fala é mais uma comprovação da força das folias na vida dos luizenses demonstrando orgulho:

"O que mais me sustenta nesta vida difícil que levamos é as recompensas e proteções que o Divino nos dá por cedermos um pouco de nossa vida para o levá-lo para dentro da casa das pessoas. Não sei te dizer como lembro dos cantos, é uma coisa natural, sempre as pessoas até brincam que é só gritar "ééé..." que se imita um grupo de folia e como isso me ofende sabe, Rafael... Por exemplo, tudo que cantamos representa algum sentido, este "ééé..." que falei, lembra que o Espírito Santo desce sobre as pessoas e fala em línguas, formas diferentes. O sentido do que fazemos é a razão da vida de muitas pessoas ainda neste mundão de hoje..."244

Tanto os grupos de folia como os devotos acabam formulando por meio de representações como esses cantos, uma maneira de referendar seus sentimentos e suas vivências cotidianas, em modelos que se ligam muito ao campo religioso, mesmo que seja com alguma autonomia da Igreja, mostrando a profunda vinculação que possuem a padrões coletivos de identidade e que acabam sendo o verdadeiro fundamento de suas vidas.

Uma análise interessante dos rituais dos grupos de folia é feita pelo antropólogo Carlos Rodrigues Brandão ao considerar o ritual popular de visitação como sendo uma forma de trazer influências da rua para a casa e em

\footnotetext{
244 Entrevista com José de Arimatéia - mestre da folia de Reis de São Luiz do Paraitinga - realizada no dia 24 de junho de 2006. Pedi para que escutasse este canto analisado, sendo sua explicação muito elucidativa para a minha análise posterior.
} 
correspondência um devolver das casas à rua e à sociedade de forma mais ampla. ${ }^{245}$ Esse alegre invadir das casas, na maioria das vezes, acompanhado de bailes musicais e muita comilança, é totalmente impensável nas culturas de origem anglo-saxã, segundo o mesmo Brandão. ${ }^{246}$

Nesta mesma linha de pensamento Roberto da Matta refere-se à complexidade de relações culturais típicas brasileiras como produtoras de uma "sociedade relacional". ${ }^{247}$ Casa e rua englobam, muito mais do que apenas espaços físicos, pois uma série de ações sociais e padrões culturais diferenciados, dividem estas duas esferas de ação das pessoas. O espaço público está a todo instante dentro da privacidade da vida do brasileiro assim como o inverso é também marcante. Dentro de uma festa como a do Divino, o aspecto sobrenatural acrescenta um novo espaço para as relações entre os populares, que Da Matta destaca como sendo o espaço do "outro mundo" e que traz novas respostas para situações típicas da casa ou da rua. Só se pode entender a sociedade brasileira levando em conta essas especificidades e que casa, rua e "outro mundo" são extremamente dinâmicos. ${ }^{248}$

Ao exemplificar que o tempo é um termo diferenciado assim como o espaço nas relações culturais, Da Matta usa um estudo de Evans-Pritchard sobre o sistema social de um grupo tribal do Sudão, os nuer. Neste grupo, tanto as classes diferenciadas de idade como as condições ecológicas são as responsáveis por avaliar o tempo. ${ }^{249}$ Ao entrevistar as pessoas mais velhas dentro dos grupos folclóricos, as principais referências quanto ao tempo e ao espaço da festa do Divino luizense estão delimitadas por épocas de influência de determinadas pessoas ou grupos e não um detalhamento maior ligado ao calendário. As noções sobre o tempo, com certeza, são totalmente diferentes entre os nuers e os participantes das festas do Divino mas, estes últimos, comumente ainda falam semelhantemente ao seu Dito Urbano: “ $o$

\footnotetext{
245 BRANDÃO, Carlos Rodrigues. O Divino, o Santo e a Senhora. Rio de Janeiro: Fundação Nacional da Arte, 1978. páginas 13-20.

246 Ibid pg 58.

${ }^{247}$ Roberto da MATTA. A casa \& e a rua. Rio de Janeiro: Rocco, 1997 - pg 25.

248 Ibid, pg 18.

${ }^{249}$ Evans-Pritchard, 1978, apud Roberto da MATTA, ibid pg 33.
} 
povo não regula mais cantar e trabalhar como naquela época da folia do Dito Geraldo". 250

Mesmo com as lavouras cada vez mais decadentes e suas vidas mais precárias pela difícil situação econômica da zona rural luizense, seus habitantes enxergam nas promessas do Divino uma das únicas possibilidades de sucesso. Assim fala o sitiante Nelson da Silva:

"A Folia passa às vezes em casa de pessoas tão humildes, que às vezes não têm o que comer. Elas fazem questão de guardar uma prenda o ano todo, para dar pro santo. Um frango... as vezes ele não faz o frango para o filho dele comer, mas ele guarda para o santo, porque tem fé. O santo vai ajudar ele, o Divino" 251 .

\section{6 - O conceito de reciprocidade e o dia-a-dia da festa do Divino luizense}

É muito forte no catolicismo popular a idéia de reciprocidade, sendo a Festa do Divino e os instantes de sua preparação momentos para se estabelecerem os pactos com o sagrado, resultando em promessas geralmente cumpridas nos momentos da festa. Levar a sua bandeira na procissão com os símbolos das graças alcançadas é uma dessas modalidades. De maneira importante e causadora de muitos conflitos, esta relação com o sagrado geralmente prescinde da atuação da Igreja e de seus agentes eclesiásticos, afinal, quem carrega a bandeira são pessoas identificadas como de seu grupo social. Mesmo quando um poderoso é o festeiro do Divino, parece que ao empunhar a bandeira, transforma-se em um cidadão comum a serviço do Espírito Santo assim como todos os outros - é novamente a excepcionalidade dentro da organização social dessas pessoas. A devoção de toda a população frente às bandeiras do Divino é muito grande. Logo a seguir a imagem de várias bandeiras demonstra o quanto cada uma pode ser ornamentadas, entretanto, não há nenhuma espécie de diferenciação e importância entre as bandeiras.

\footnotetext{
${ }^{250}$ Benedito Urbano, 75 anos, do bairro do Pinheirinho, referia-se ao nome mais destacado das folias que percorreram a festa do Divino nos últimos tempos, o Benedito Geraldo - o mesmo da gravação - falecido em fins dos anos 90, tendo passado praticamente toda sua vida andando a cavalo, cantando e recolhendo prendas para o Divino. Quando perguntei em que ano mais ou menos se passava esta época em que dava maior destaque à festa, seu Dito Urbano foi taxativo: "A época do Dito Geraldo 'oras" ".

${ }^{251}$ Nelson da Silva apud GOUVÊA, Tânia Moradei- GARCIA, Patrícia Lombardi. Os arquétipos do sagrado na alegoria da Festa do Divino Espírito Santo de São Luiz do Paraitinga, Taubaté, UNITAU, 1995.
} 
Foto 01 - Fiéis empunham suas bandeiras dentro do Império do Divino (2007)

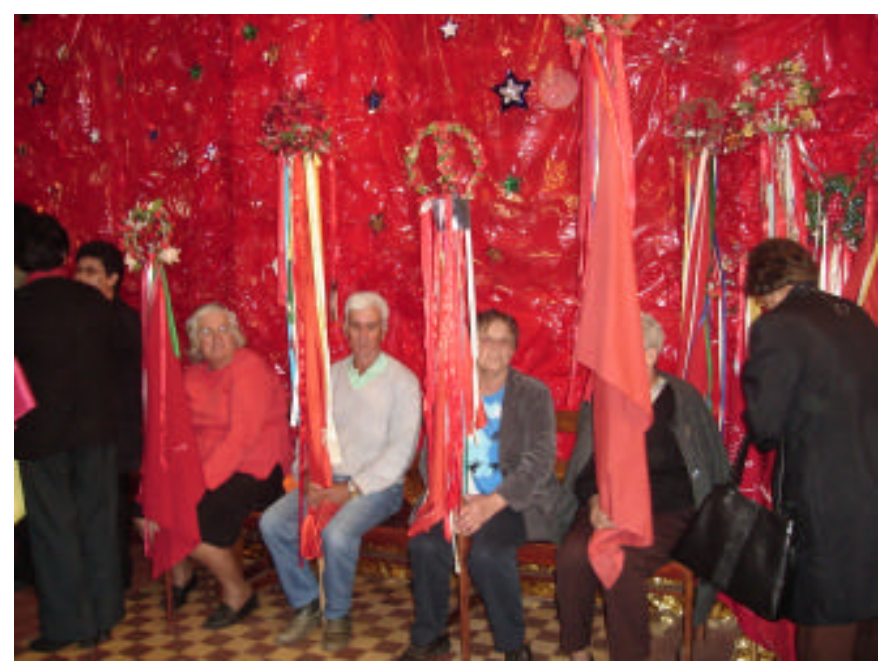

Fonte: acervo pessoal do autor

O autor Marcel Mauss, ao estudar o tema da troca na sociabilidade humana, traz idéias interessantes com relação à noção de reciprocidade. Em seu "Ensaio sobre a dádiva" ${ }^{252}$ demonstra a estrutura de trocas como uma atuação social: ao dar algo se pressupõe seu retorno. Diz que nas sociedades arcaicas este sentimento era ainda mais forte, daí estudar detalhadamente o caso dos "kwakiutl" (povo da costa noroeste da América do Norte) e seu ritual de trocas, o "potlatch".

Os kwakiutl, conta Marcel Mauss, possuíam uma produção de certo modo abundante de alimentos, frutos da caça e da coleta, além de uma importante pesca de salmão. Faziam o armazenamento destes alimentos sem possuir a idéia de acumulação. Muitas vezes passavam privações nos últimos momentos do inverno e pouco tempo antes, haviam realizado o "potlatch". No inverno rigoroso, quando se reúnem em uma espécie de unidade familiar (clã), o líder deste grupo convida outro clã para as festividades do "potlatch".

Em princípio, parece um ato de generosidade, onde se trocam presentes trabalhados durante todo o ano entre os líderes dos clãs, mas o ritual não pára por aí. Consomem-se, de maneira intensiva, todas as reservas alimentares armazenadas e inclusive se destrói o que restar, causando, dependendo do tamanho do potlatch, até constrangimento no receptor. Isso porque quem o recebe terá de retribuí-lo na próxima temporada, e quanto maior o ritual maior a dificuldade de correspondência.

\footnotetext{
${ }^{252}$ Marcel MAUSS. Ensaio sobre a dádiva: forma e razão da troca nas sociedades arcaicas in Sociologia e Antropologia- volume II Edusp, São Paulo, 1993.
} 
Desta forma mais do que generosidade acaba-se estabelecendo uma forte relação de sacrifício, fundamental no processo de afirmação de simbologias e identidades comuns entre os grupos participantes do potlatch. Essas trocas causam uma espécie de sistema de reciprocidade compulsória, eu me faço reconhecer ao outro por meio do presente que dou e este o retribuirá, trazendo essa idéia de identidade coletiva. A troca e reciprocidade, para Mauss, são os fundamentos da vida social.

Isso pode ser constatado na Festa do Divino. Ela estabelece tanto uma relação de reciprocidade - presente na distribuição do "afogado" - quando todos comem o que todos doaram, como de sacrifício na doação de prendas - você transfere algo de seu patrimônio para outrem. A distribuição de comida durante é festa é cercada de um cerimonial tão grande que podemos considerála uma espécie de eucaristia social, sem o controle do clero, onde cada um partilha um pouco do outro com o qual se identifica. Quando alguém incorpora esse sentido de comunhão e sacrifício presente na festa, passa a participar de um processo de "vibração da densidade do sagrado" 253 , acabando as hierarquias de todas as ordens. Todos passam a ser iguais socialmente.

“ Assim, o sacrifício veio a ser rapidamente considerado a condição mesma da existência divina. É ele que fornece a matéria imortal de que vivem os deuses. Desse modo, não somente é do sacrifício que nascem alguns deuses, mais ainda é pelo sacrifício que todos conservam sua existência.",254

Como mencionado no primeiro capítulo, esta ligação direta entre o indivíduo e o sagrado é uma marca do catolicismo popular, que move as populações mais simples - os maiores atores e que fazem realmente a festa acontecer. Uma primeira conclusão desta pesquisa ao analisar a festa do Divino de São Luiz do Paraitinga é que mesmo com sua organização sempre ligada às elites, percebemos ser a população mais simples quem realmente faz a festa acontecer, construindo praticamente todas as simbologias a que estamos sempre indicando. Embora tenha defendido a origem da festa conjuntamente às elites, a história demonstra não


setembro de 2007.

${ }^{254}$ MAUSS, Marcel; HUBERT, Henri. Sobre o sacrifício. São Paulo: Cosac Naify, 2005. página 97.
} 
significar ser esse grupo social o responsável pela criação da festa. Pelo contrário, é a própria elite que para se legitimar traz a festa para perto de seu controle.

Após as peregrinações da folia e da bandeira do Divino e, arrecadados os fundos para a realização (todo o lucro da festa é destinado à Igreja), dá-se inicio à festa numa sexta-feira, com o primeiro dia de uma novena na Igreja Matriz onde serão também bentas as bandeiras dos fiéis.

Em todos os dias subseqüientes serão realizadas procissões ampanhadas pela banda musical da cidade antes do início de cada novena e após seu término, buscando e levando a bandeira oficial da festa no trajeto do Império - local onde fica a bandeira do festeiro durante toda a festa - para a Igreja Matriz. Os fiéis que possuem suas bandeiras geralmente assumem uma promessa de não faltar a nenhum dos nove dias de celebração e acompanhar as procissões.

Temos de dar destaque a uma outra procissão tradicional da festa luizense que acontece no $1^{\mathrm{o}}$ sábado da Festa, geralmente, às dezesseis horas. Chamada de "procissão do encontro", é um momento simbólico em que a bandeira que percorreu a cidade o ano todo em peregrinação junto da folia e do festeiro - a mesma que vai ficar no Império -, encontra-se com as dos fiéis, sobretudo, as da zona rural.

Percebemos neste momento de coroação e agradecimento - por mais um ano de peregrinação das folias - a reafirmação de muitos elementos típicos da cultura tropeira, como foi apresentado no histórico da festa. As dificuldades enfrentadas na peregrinação, a união proporcionada na comunidade pela passagem da folia, o exemplo de dedicação e fé dos foliões estão agora traduzidos naquela simbólica bandeira oficial da festa do Divino do ano - um dos símbolos mais aglutinadores da comunidade luizense.

Para fazer jus à importância de abrigar essa bandeira na festa, a sala do Império é o local mais bem ornamentado nos espaços utilizados por esta manifestação. Em seu interior predomina a cor vermelha - para toda a comunidade, a cor do Divino. Ali ficarão as bandeiras, o cetro e a coroa, símbolos do Império do Divino, que durante a festa transformam este local num dos de maior destaque na cidade, trazendo além de toda devoção popular, um caráter de miscigenação, afinal, estão expostos símbolos da nobreza, por sinal, reafirmados desde os princípios da 
festa em nosso país conjuntamente com a maciça participação e devoção dos populares. Retratos, chupetas, utensílios pessoais são depositadas nas bandeiras "pomposas" e cheias de símbolos da nobreza. Abaixo vemos um dos membros da folia do Divino com a bandeira que percorreu todo o ano de 2007 em peregrinação. Destaque as fotos, fitas e chupetas citadas logo acima e penduradas na bandeira:

Foto 02 - Membro da folia do Divino carrega a bandeira da festa (2007)



Fonte: acervo pessoal

Uma transformação importante que encontramos na análise da festa se relaciona com o espaço do Império. Como citado anteriormente nos documentos utilizados para o início da festa do Divino em São Luiz do Paraitinga, o Império demandava uma construção específica para o seu estabelecimento. Algo que deixou de existir. Embora se mantenha sempre na praça Dr.Oswaldo Cruz - principal ponto da cidade - ele é móvel estabelecendo-se em cômodos livres ou desocupados para este fim dos moradores desta praça. Representa uma transformação nesta relação muitas vezes tensa entre ao público e o privado. Não existe mais o lugar específico do Império e sim um ambiente particular cedido a este. Há de se imaginar, como na questão do status social ser determinante na escolha do festeiro que o mesmo ocorra com a escolha do local privado que abrigará o Império.

Voltando à discussão simbólica, a realeza e o Império dão ainda ao Divino, confirmando as tantas analogias entre o poder e o sagrado, a conotação de inspiração e poder que vem de Deus, sendo o iluminador e o propagador dos dons do Espírito Santo. Um grande exemplo da faceta sagrada do poder real perante a população é o livro "Os Reis Taumaturgos", de Marc Bloch, cujo tema é a crença de que os reis, 
particularmente os da França e Inglaterra, tinham o poder de curar os doentes de escrófulas através da imposição de suas mãos. ${ }^{255}$

Bloch discorre sobre a história de um certo tipo de milagre abordando aspectos simbólicos que percorreram toda a Idade Média e chegaram até a modernidade. São os símbolos próprios das realezas, com o caso específico do poder da unção curadora das escrófulas, demonstrando a ligação do dom régio legitimado ao se aproximar do sagrado. A festa do Divino constitui uma realidade totalmente diversa desta anterior, entretanto, a legitimidade da representação de seu imperador perante a sociedade é toda baseada nesta mesma relação entre o sagrado e o poder vigente. Marina Mello e Souza disserta sobre este poder sagrado marcante desde a realeza medieval e reinterpretado em nossos dias:

“A associação entre o rei e a divindade está presente na grande maioria das culturas documentadas através dos tempos. (...) $\mathrm{O}$ entrelaçamento entre o sagrado e o profano expresso na figura do rei permitia trocas entre noções teológicas e legais a respeito de definições da sua essência e atribuições. Esse intercâmbio entre os poderes de Deus e os poderes dos homens refletiu-se no cerimonial em torno do rei." 256

A herança deixada pelo destaque das pessoas ligadas às esferas do poder real, sempre mais fortalecidas por serem acompanhadas da acepção do sagrado, mantém, ainda hoje, um paralelo semelhante. Há a construção da ligação de que todo cargo de destaque, dentro da organização do Divino, - sem nunca eliminar a característica da construção da idéia de igualdade em uma identidade coletiva - permite tornar alguns mais importantes do que outros dentro deste mesmo grupo dito tão igualitário. E, como de se imaginar, o reflexo do poder existente no dia-a-dia da sociedade é diretamente transferido aos que comandam a festa religiosa.

Fica assim mais fácil de compreender a força do simbolismo da figura do festeiro do Divino. Este costuma ser uma pessoa de destaque na cidade e a boa condição financeira é quase pré-requisito. Mesmo porque, é necessário o abandono de várias atividades do dia-a-dia para a peregrinação durante o ano ao lado da folia.

\footnotetext{
255 Marc Leopold Benjamin BLOCH. Os reis taumaturgos: o caráter sobrenatural do poder régio, França e Inglaterra. São Paulo: Companhia das Letras, 1993.

${ }^{256}$ SOUZA, Marina de Mello e. Reis Negros no Brasil escravista: história da festa de coroação do Rei Congo. Belo Horizonte: Editora UFMG, 2002. páginas 25-29.
} 
$\mathrm{Na}$ verdade, a análise da festa tem demonstrado que é cada vez mais raro o festeiro acompanhar o dia-a-dia da folia em suas peregrinações. Acaba indo nos fins-desemana e nas casas das pessoas de maior destaque na sociedade. De qualquer forma, ao assumir o preparo dessa festa é necessário muita dedicação à sua realização.

A organização da festa na época de prosperidade cafeeira do município era assumida sobretudo por coronéis, grandes fazendeiros, que chegavam inclusive a tirar proveitos eleitorais dessa função e, tudo isso, possivelmente, sem maiores empecilhos da Igreja. Esta era, e ainda é, a responsável pela escolha dos festeiros e pelo andamento da festa e não colocaria obstáculos a essa situação, afinal, era maior a probabilidade de uma maior arrecadação com os poderosos no comando.

É bom lembrar que uma vez paga as despesas da festa, o excedente da arrecadação sempre retornaria à Igreja e possibilitaria ainda um maior controle da população sob sua doutrina. Situação, aliás, que se mantém, pois coincidentemente ou não, os dois últimos festeiros da festa do Divino de São Luiz do Paraitinga foram o atual prefeito, Danilo José de Toledo (2006) e seu vice Luiz Carlos Luzia Rodrigues (2007).

Voltando aos rituais da festa do Divino, durante os dias da novena, a parte conhecida como profana da festa acontece nas ruas da cidade movida por shows musicais, um comércio já tradicional de ambulantes, a distribuição de comida à população no primeiro sábado da festa, entre vários outros exemplos. Entretanto, é no último fim-de-semana que a festa ganha uma feição ainda mais profana. Sobretudo, no último domingo da festa, apresentam-se grupos folclóricos variados: congadas, moçambiques, folias originárias de vários locais da região, além de brincadeiras como do pau-de-sebo e do casal de bonecões João Paulino e Maria Angu. A tradicional distribuição do afogado é um evento de muito destaque. Muitos que deram a prenda ao Divino, enxergam na comida que recebem gratuitamente uma resposta direta à sua fé, conforme a idéia de troca proposta por Marcel Mauss. Todos doam uma prenda ao Divino e recebem a comida abençoada como resposta e meio de proteção. A benção do afogado pelo clero, como na imagem abaixo, é algo muito simbólico e representativa dessa ligação entre a religiosidade popular e o clero instituído presente nas festas do Divino. 


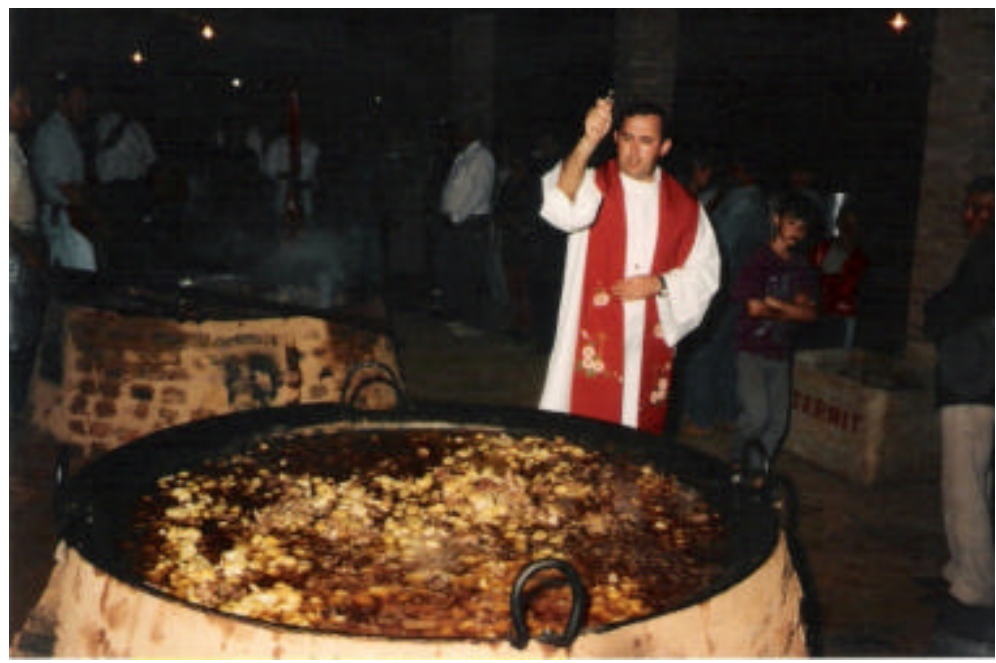

Fonte: acervo pessoal Dona Didi Andrade

O domingo principal da festa é tradicionalmente chamado como o "Grande Dia" pela população. Logo ao amanhecer, a cidade é acordada com o toque da alvorada executado pela Corporação Musical São Luiz de Tolosa ${ }^{257}$ e, muitas vezes, acompanhada de perto por outros grupos folclóricos que já chegam à cidade desde o fim da madrugada. Durante o dia, a interação entre a população visitante, os munícipes, os grupos folclóricos locais e de cidades visitantes e celebrações religiosas, constitui um ambiente literalmente de "festa"! Com as manifestações acontecendo simultaneamente pelo centro histórico da cidade encontramos uma situação de quebra total do pacato cotidiano dessa localidade.

O último ato paralitúrgico da festa é a Procissão do Divino, que, por sinal, é o momento mais esperado pelos participantes. Dela participam o Imperador, representado geralmente por uma criança, o festeiro atual, e o novo festeiro que é apresentado a toda a comunidade. Integram ainda ao cortejo as Irmandades do Santíssimo Sacramento e a de São Benedito, a folia do Divino, grupos de moçambique e congadas. O andor do Divino, trazendo os símbolos da pomba e da

\footnotetext{
${ }^{257}$ Esta corporação musical é mais uma das entidades de destaque na preservação cultural de São Luiz do Paraitinga. Com quase 200 anos de existência, a população enxerga como fundamental a sua presença nas principais procissões e manifestações religiosas. Sua apresentação musical é, por exemplo, parte constituinte das procissões do Divino na concepção de todos participantes, intercalando-se com a reza do terço do chefe da Igreja. Há vários exemplos de conflitos da população com a Igreja por eventuais desentendimentos entre a Corporação com os agentes eclesiásticos. E, na maioria das vezes, a população acaba colocando-se em defesa mais forte da banda musical em detrimento ao clero.
} 
coroa, sai ricamente adornado e é conduzido por guardas de honra. A banda musical e a multidão de devotos, sempre em atitude de fé e reverência, percorrem as ruas mais tradicionais da cidade.

Observemos na foto abaixo a atenção do público na saída do andor do Divino Espírito Santo da festa de 2007. O predomínio da cor vermelha é marcante e o ambiente da saída da procissão é sempre de muita devoção e comoção dos populares:

Foto 04 - Saída da procissão do Divino de 2007



Fonte: acervo pessoal do autor

Ao findar a procissão, inicia-se a missa vespertina que vai coroar o novo festeiro. Com essa atitude, a festa é sacramentada e legitimada. Aparece aí mais uma especificidade da festa luizense, pois, na maioria das cidades que mantém a festa do Divino, o ápice da festa é a coroação do Imperador que foi o festeiro do ano. Em São Luiz, já se coroa o do ano seguinte e, a não ser que ainda não exista um escolhido, já se daria uma prova de que a festa existe num círculo que nunca cessa. $O$ fim de uma festa representa o reinício dos trabalhos para a vindoura.

A não nomeação do próximo festeiro é um dos principais meios que a Igreja tem utilizado para tentar controlar mais a festa, montando, como em 2005, comissões para a organização desta entre pessoas atuantes nas pastorais e comissões 
da paróquia local e, conseqüentemente, mais próximos de seu controle ${ }^{258}$. Durante a procissão simplesmente se suprime o ato de coroação do novo imperador. E serão expostos os argumentos do clero para essa decisão na tradicional homilia que encerra a procissão e acontece dentro da Igreja Matriz. A população, em sua ampla maioria, sempre tem se posicionado de forma totalmente contrária a tentativas como essa; prova disso foi novamente a nomeação de festeiros nos anos seguintes a 2005.

\section{7 - A proeminência do rei do Congo na festa do Divino de São Luiz do Paraitinga}

Um caso exemplar da riqueza cultural dos grupos da cultura popular presentes nas festas do Divino de São Luiz do Paraitinga é a apresentação das congadas. Preservando ainda hoje valores de séculos passados, ligados à questão, neste caso, da escravidão, servem ainda para muitos, como elemento de reforço de identidade e ligação dos laços ancestrais de seu grupo com a África.

"O que é interessante destacar nas danças dramáticas que ficaram conhecidas como congadas e nas festas do rei Congo em sua totalidade, é que foram formas culturais criadas pelas comunidades negras na sociedade escravista, que ao mesmo tempo que adotaram padrões institucionais lusitanos e valores católicos, reforçaram os laços com a África natal’"259.

Tânia Moradei, jornalista, relata que em setembro de 1981, durante o Simpósio Internacional da Música Sacra e Cultura Brasileira, que realizou alguns eventos em São Luiz do Paraitinga, Salvador Barbosa foi nomeado rei do Congo. É importante ressaltar como característica marcante da festa luizense a presença do Rei do Congo como figura de destaque. Seu papel nas procissões, no cerimonial de escolha do Rei do Congo, na organização da festa de uma forma geral, faz desta figura um dos ícones na identidade da festa partilhada pelos luizenses. Uma marca da miscigenação das culturas - que tem de ser ressaltada ainda mais -, por

\footnotetext{
${ }^{258}$ Nas últimas décadas a festa foi diversas vezes organizada ou pelos próprios padres ou por comissões de religiosos. São também bastante significativos os conflitos com grupos folclóricos, população e Igreja nestes mesmos anos.

${ }^{259}$ SOUZA, Marina de Mello e. História, mito e identidade nas festas de Reis negros no Brasil- séculos XVIII e XIX. In JANCSÓ, Istvan; KANTOR, Íris (org) Festa: cultura e sociabilidade na América Portuguesa. São Paulo: Hucitec: Edusp: Imprensa Oficial: Fapesp, 2001.
} 
apresentar a convivência de um personagem de origem estritamente popular, exercendo um papel destacado no interior da festa, originadamente, organizada pelas irmandades brancas e, portanto, muito distante da possibilidade de ceder um espaço de destaque justamente a um ícone das irmandades negras.

Mas o Rei do Congo é figura marcante na festa do Divino contemporânea de São Luiz do Paraitinga e a idéia das tradições africanas ressaltarem a especificidade dos reis serem perfeitos fisicamente e moralmente é ainda disseminada pela cultura popular luizense. Imperfeições implicariam no empobrecimento da vida do grupo, em enchentes, colheitas fracas etc. É a legitimidade do poder terreno através do sagrado como discutimos no tópico anterior. O relato do rei do Congo luizense - seu Salvador Barbosa - recolhido por Tânia Moradei, esclarece essa questão:

"Não é qualquer um que pode ser rei. Tem que ser bom, não beber, não responder para os outros. O rei é respeitado pelas autoridades, o juiz, o prefeito. É registrado e tudo, é a mesma coisa que uma autoridade"260.

Mais uma vez a idéia de identidade e de inversão de posições sociais permitidas no momento de excepcionalidade da festa quando ele se transforma em um verdadeiro líder das festividades. O papel do rei do Congo na festa luizense, mais uma vez, é algo excepcional dentro das tradições de louvor ao Divino em outras cidades brasileiras, causando, no mínimo, estranhamento. Como adiantei há pouco, é extremamente singular a importância que o rei do Congo possui na festa, pois ao longo da história sua presença está limitada às sempre discriminadas irmandades dos “irmãos pretos", envolvidas, sobretudo, nas festas de São Benedito e de Nossa Senhora do Rosário.

Chama mais a atenção ainda em São Luiz do Paraitinga as dificuldades que enfrentam as festas de São Benedito e a de Nossa Senhora do Rosário na atualidade e a ausência da presença do Rei do Congo nestes eventos. Conta o luizense Marco Rio Branco que a festa do Rosário, décadas atrás, era um evento de apresentação de música erudita, totalmente em dissonância com sua origem popular:

"O Rei do Congo nunca nem esteve presente na festa de Nossa Senhora do Rosário em São Luiz. Lembro que duas décadas atrás, esta festa de Nossa

${ }^{260}$ Salvador BARBOSA apud GOUVÊA, Tânia Moradei- GARCIA, Patrícia Lombardi op cit pág 15. 
Senhora nem na rua acontecia, eram realizadas várias apresentações de músicas sacras e eruditas no interior da própria Igreja do Rosário. De uns anos pra cá que ela vem tomando o espaço da rua e retomando os temas da negritude e da participação de grupos como as congadas, entretanto, algo ainda muito incipiente."261

Quanto à festa de São Benedito ela praticamente não existe mais em São Luiz do Paraitinga. Era ainda, até a década passada, uma das principais festas religiosas da cidade realizada sempre na segunda-feira após a Páscoa. Além de uma diminuição do público nos últimos anos ela foi transferida, por imposição do clero local, para o dia oficial de São Benedito comemorado pela Igreja Católica, especificamente cinco de outubro, no caso, de 2004, e, definitivamente, a festa entra em forte declínio. No ano de 2007 a festa ficou restrita a um tríduo na Capela de São Benedito e a realização de bingos e quermesses com fraca presença de devotos e do público em geral. Não houve nenhum grupo de congada se apresentando e a figura do Rei do Congo, que seria primordial nesta festividade nem sequer apareceu.

Essa espécie de "migração" do rei negro do Rosário para o Divino é algo muito interessante na festa luizense e que, infelizmente, não consegui esclarecer nesta pesquisa. A questão torna-se ainda mais complexa quando constatamos que membros de uma comitiva oficial do Vaticano estavam presentes no Simpósio de Música Sacra de 1981, realizado em São Luiz do Paraitinga, e participaram da nomeação de um Rei do Congo oficial na cidade. Aliás, os atos que ainda elegem o rei do Congo são cercados de grande atenção da comunidade. Na procissão do Divino, ele tem um destaque comparável ao do festeiro. Sai vestido, com símbolos históricos das irmandades negras, como anel, crucifixo ${ }^{262}$, contudo, seus ornamentos lembram muito os da realeza presentes nas vestes do imperador e do andor do Divino. ${ }^{263}$ A imagem abaixo nos mostra esta simbologia real transferida a uma imagem formada no âmbito da símbolo da cultura negra. Chamo a atenção para a posição de destaque ocupada pelo rei César e pela rainha Fátima - sucessores de seu

\footnotetext{
${ }^{261}$ Marco Antonio Rio Branco, poeta e músico local em entrevista em maio de 2008.

262 Objetos originários das irmandades negras conforme dito pelo atual rei do Congo na festa do Divino de São Luiz do Paraitinga de 2007.

263 Marina Mello e Souza descreve no "Reis Negros no Brasil Escravista" op cit, ser tradição do reis negros usarem cetro, coroa e manto há muito tempo, como o próprio imperador do Divino. Entretanto ela não cita situação em que o rei do Congo faça parte da festividade do Divino.
} 
Salvador Barbosa e sua esposa - bem a frente do andor do Divino Espírito Santo, principal símbolo da procissão.

Foto 05 - Rei e Rainha do Congo na festa de 2005

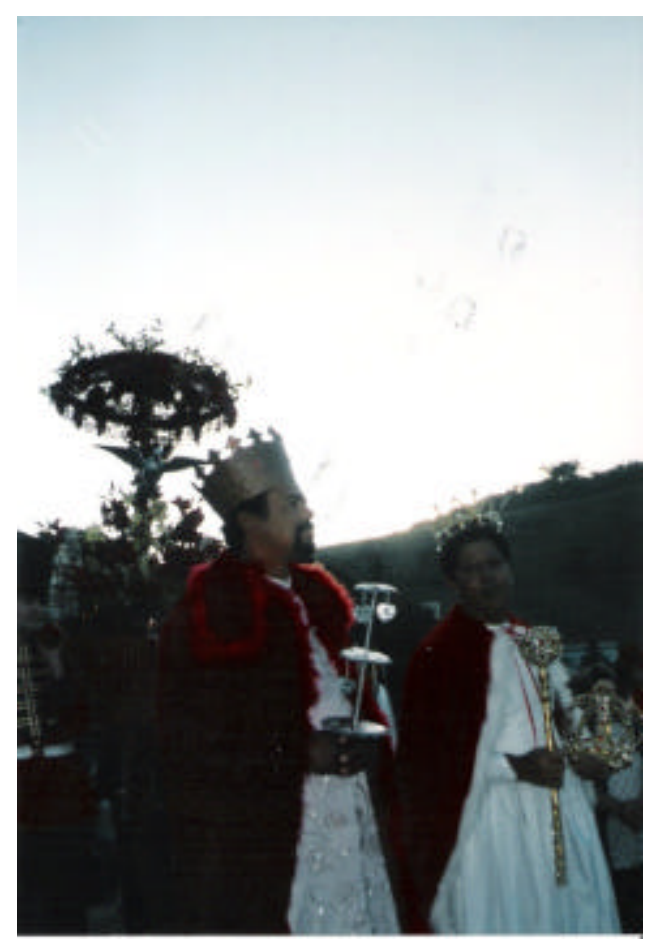

Fonte: acervo pessoal do autor

O Simpósio de Música Sacra, em 1981, foi um grande acontecimento para os luizenses, até hoje muito comentado pela cidade. Visava legitimar, através de uma postura do Vaticano - por mais incrível que possa parecer - a eleição do rei do Congo e a afirmação de sua influência dentro da cultura popular local. O processo de coroação do seu Salvador Barbosa Rei ${ }^{264}$, mostrou todo o sincretismo da cultura brasileira vivenciado pela comunidade luizense: o próprio ato de eleger como rei um ícone das camadas populares desfavorecidas e colocá-lo em destaque na principal festa da cidade é algo extremamente diferenciado. Ao mesmo tempo, seu Salvador era um autêntico mantenedor das tradições africanas, prezado pelo seu destaque dentro de seu grupo, e, como vimos em sua fala anteriormente, crente em não possuir imperfeições físicas e morais. Foram então, por meio dele, também legitimando dentro da Igreja Católica, com um documento oficial desta, os valores de seu grupo de origem, tão desprezado na história da própria Igreja. O documento

\footnotetext{
${ }^{264}$ Alterou seu nome de Salvador Barbosa para Salvador Barbosa Rei após ostentar o título de rei do Congo em 1981.
} 
citado é uma espécie de certificado oficial da Igreja Católica, assinado pelo então bispo diocesano Dom Antonio Afonso Miranda, nomeando como Rei do Congo, seu Salvador Barbosa. ${ }^{265}$

Benedicta Antunes de Andrade, a dona Didi, é uma senhora responsável pela realização de muitas tradições da festa luizense em seus quase 60 anos de trabalho dedicados à festa do Divino e à Igreja de uma forma geral. É ela a responsável pela ornamentação da maioria dos andores, do império do Divino, da apresentação da dança de fitas entre muitas outras atribuições durante os dias do folguedo. Perguntada sobre a presença do rei do Congo na festa luizense, disse o seguinte:

"É tanta coisa nesta festa que não saberia dizer com certeza se o rei do Congo sempre existiu ou se foi uma coisa que colocamos para deixá-la mais bonita. Afinal, os negros precisam mostrar que são importantes em nossa cidade. Desde a época do café, construíram muita coisa e suas danças como as congadas são muito bonitas e apesar de meio diferentes, são importantes pois cultuam o nosso mesmo Deus". ${ }^{266}$

Suas palavras, mesmo não esclarecendo o surgimento do rei do Congo dentro do culto ao Divino, são enfáticas quando fala da complexidade cultural da festa. Questões religiosas, étnicas, culturais estão presentes em sua fala e mostram sua força na constituição da festa. Podemos dizer que a inserção do negro nas manifestações católicas luizenses é mais um momento especial dentro da história cultural da sociedade brasileira, haja vista a dificuldade de estes estarem em destaque nas manifestações religiosas.

Benito Campos, poeta local, escreveu em janeiro de 2008 um discurso em homenagem ao sr. Alcides Pereira de Castro que por muito tempo foi um dos líderes de mais destaque das congadas da região e que comprova a continuidade da importância destas pessoas na sociedade luizense. Foi feito inclusive um boneco em sua homenagem que desfilou no Carnaval luizense de 2008. Seu Alcides, tamanha sua importância entre os populares, foi alçado também ao cargo de Rei do Congo na cidade, após a morte do seu Salvador Barbosa. Atualmente, desde o falecimento de

\footnotetext{
265 Datado de 02 de setembro de 1981 este certificado é guardado com orgulho pela família de seu Salvador Barbosa.

${ }^{266}$ Benedicta Antunes de ANDRADE em entrevista no dia 10 de março de 2006.
} 
seu Alcides, o cargo de Rei do Congo é ocupado por César Barbosa, filho do seu Salvador:

\section{“Discurso ao Rei Nobre do Congo, Arcidão}

Antes de iniciarmos e rompermos marcha com a Maricota, nós gostaríamos de prestar aqui uma homenagem a Alcides Pereira de Castro, capitão general de todas as Congadas do Paraitinga e, através dele, aproveitamos também o ensejo para homenagear o Raizeiro, Dona Dita, Vicente Ambrósio, Pai João, Zé e Chico Prateano e tantos outros que já se foram. Exigimos de vocês sim um silêncio respeitoso para ouvir, por alguns momentos, umas palavrinhas tão necessárias para estas figuras de fé e de alegria que, no seu caminho de luz, iluminados prossigam dançando e cantando lá no céu:

(Apito)

... Tremula ao alto a espada do grande guerreiro que, erguendo os gládios e brandindo as hastes, lá si foi o nosso inigualável Rei do Congo com seu apito de comando. Que sibile em sua homenagem um último silvo, decrescente, sibile si perdendo ao longo...

(Apito longo)

Adeus, adeus

Eu me fui s'imbora

Me despi da dor

Qui'á saudade chore..."267

A inserção do Rei do Congo na festa luizense está associada ainda à mais uma excepcionalidade: em 1981 teriam acontecido duas festas do Divino em São Luiz do Paraitinga. A própria Dona Didi Andrade nos lembra que este Simpósio da Música Sacra, onde se nomeou Salvador Barbosa como o Rei do Congo, foi acompanhado pela realização de uma " nova" festa do Divino naquele ano:

" Como iam vir os representantes do Vaticano para o evento e para nomear o Rei do Congo foi necessário, o padre Tarcísio achou por bem assim, montar uma nova festa do Divino. Pra turma do Vaticano ver o quanto era importante o Rei do Congo, né? (...) Então teve tudo: novena, procissão do mastro, congadas, moçambiques, dança de fita e, tudo isso, acompanhada por gente grande da época. Estavam o governador Maluf, o secretário de cultura

\footnotetext{
267 CAMPOS, Benito. Discurso em homenagem ao "Rei Nobre do Congo, Arcidão", acervo pessoal, São Luiz do Paraitinga, 26 de janeiro de 2008.
} 
Cunha Lima e todos políticos da região (...) e o povo saía meio sem saber se era hora de cumprir as promessas ou de ver os políticos. Foi até engraçado!"268

Representantes da Igreja Católica nomeando Rei do Congo, a quebra do calendário tradicional, a população interagindo com essa situação excepcional, a reafirmação da importância do Rei do Congo no interior da festa, são alguns dos pontos extremamente simbólicos desse "caldeirão cultural" com o qual estamos tendo contato. A relação conflituosa dentro do campo religioso aflora nessa fala de Dona Didi e, aliás, gostaria de discutir ainda um pouco mais esse ponto antes de finalizar esse capítulo.

Antes gostaria de transcrever o ofício do então chefe do gabinete da secretaria de cultura do estado de São Paulo, sr. Renato J. B. Della Togna, exibido com tanto orgulho por D. Didi Andrade, solicitando a sua dispensa de seu ofício junto ao posto de I.N.P.S de Taubaté para dedicar-se integralmente ao Simpósio de Música Sacra. O documento permite perceber também a amplitude do evento que contou com exposições e apresentações na cidade de São Paulo, paralelamente a realização da segunda festa do Divino na cidade e da nomeação de seu Salvador Barbosa em 1981:

"São Paulo, 22 de julho de 1981.

OF. G. 928/81

A sua Senhoria o Dr. Ariovaldo de Castro Almeida, D.D. Agente do I.N.P.S. - Taubaté

A Secretaria de Cultura, em colaboração com a Organização Pontifica de Música Sacra " Consociatio Internationalis Musicae Sacrae" CIMS (Roma) e com o Institut fuer Hymnologische und Musik-ethnologische Studien de Maria Laach (Republica Federal da Alemanha), realizará, de 27 de setembro a 4 de outubro do corrente ano, o "SIMPOSIO INTERNACIONAL DE MUSICA SACRA E CULTURA BRASILEIRA"

Participarão da parte artística do evento os melhores corais do estado de São Paulo, bem como orquestras e solistas, fazendo uma amostragem da grande música sacra brasileira desde a colônia até os nossos dias".

Paralelamente, haverá exposição de partituras originais de compositores brasileiros no Museu de Arte Sacra e também uma exposição de santos na

${ }^{268}$ Benedicta Antunes de ANDRADE em entrevis ta no dia 10 de março de 2006 e 25 de maio de 2007. 
Galeria Cultura, bem como o lançamento do primeiro volume da 'Colectanea Musicas Sacra Brasilienais', editado pela imprensa do Vaticano.

A fim de colaborar para o desenvolvimento da promoção, solicito a Vossa Senhoria, de ordem do Senhor Secretário Extraordinário, o obséquio de examinar a possibilidade de ser dona Benedita Antunes de Andrade, agente administrativa do setor de manutenção dessa agência $n^{\circ} 61.187$ posta à disposição desta Pasta, durante 15 (quinze) dias, no período de 14 de setembro a 4 de outubro deste ano, para auxiliar nas atividades que serão desenvolvidas em São Luís do Paraitinga relativamente ao Simpósio. (...)

Renato J.B. Della Togna Responsável pela Chefia de Gabinete

Este documento, além de confirmar através de uma correspondência oficial a realização do Simpósio de Música Sacra é uma das comprovações da importância exercida por dona Didi Andrade nas festas da cidade, sendo requisitada de suas atribuições do dia-a-dia pela chefia da secretaria da cultura estadual, algo, só possível, para alguém que exercesse uma espécie de liderança frente a comunidade. Aliás, uma liderança ainda vigente na atualidade, já que dona Didi mantém-se como uma espécie de ícone cultural para a sociedade luizense contemporânea.

Já que esta pesquisa não descobriu mais detalhes sobre as motivações locais que acabaram por inserir o rei do Congo na festa do Divino, contudo, auferindo a importância que acabou assumindo no decorrer dos últimos anos, gostaria que tomássemos esta questão como uma forte confirmação do dinamismo da cultura popular que estamos tanto invocando. E que escutássemos mais uma vez a versão de dona Didi Andrade para esta questão:

"Eu não sei te dizer quando apareceu o rei do Congo na festa do Divino pois ele sempre foi um membro que acompanhou as congadas em nosso país. A maioria das congadas possui sua realeza que a acompanha nas apresentações (...). Em São Luiz já faz algumas décadas que realizamos a coroação de um rei oficial do Congo da cidade para abrilhantar ainda mais as comemorações do Divino Espírito Santo. E o seu Salvador, quando vivia, se transformou numa pessoas de muito destaque aqui na cidade, ajudando organizar mesmo os grupos de congada e sua participação nas festas da cidade. Acho que não foi por acaso que ele se transformou num rei do Congo oficial através do Simpósio de 1981."269

\footnotetext{
${ }^{269}$ Entrevista com dona Didi Andrade em maio de 2008.
} 
Mesmo tendo conversado com dona Didi Andrade em diversos estágios da pesquisa, foi somente neste seu último depoimento que ela comentou esta inserção do rei Congo na festa do Divino luizense de uma forma mais específica. Parece mesmo que a presença do rei do Congo na festa do Divino de São Luiz do Paraitinga possa ter se iniciado somente com o intuito de tornar a festa mais rica em seu brilhantismo simbólico, graças a um número maior de elementos populares durante o evento. Contudo, mesmo que de forma inconsciente, acabou gerando uma singularidade muito importante no interior desta festividade.

\section{8 - Os conflitos entre a Igreja Católica e a religiosidade popular}

Desde sua fundação, São Luiz do Paraitinga caracteriza-se por ser uma comunidade extremamente religiosa. Conta Luiz Saia ${ }^{270}$ que tão logo o fundador e povoador Manuel Antonio Carvalho chegou a São Luiz do Paraitinga, já mandou erigir uma cruz - aqui com dupla intenção: como local de culto e marca de conquista. Em torno das capelas se formavam os núcleos populacionais, sendo amplamente aceito e destacado o lugar da religião na colonização portuguesa. Entretanto, apesar da ligação entre o poder político e o religioso, o controle da religião no território brasileiro era insuficiente, até mesmo devido à ausência de agentes especializados.

Nos primeiros tempos da vila de São Luiz, essa ação da institucionalização da religião era garantida - e é até hoje em dia em alguns bairros luizenses - por um “capelão", pessoa versada em práticas religiosas, o que acabou favorecendo a uma tendência de famílias cultivarem santos, muitas vezes possuindo seu oratório, santo particular e uma religião também, de certo modo, individualizada. O caráter leigo, social e familiar apontado por Riolando Azzi quando a colonização portuguesa se implantou em nosso país e formou, o que ele chamou de "catolicismo tradicional", pode facilmente ser identificado em muitas destas manifestações que estão sendo citadas. $^{271}$

\footnotetext{
${ }^{270}$ Luiz SAIA op cit, pg 78.

271 Riolando Azzi classifica o catolicismo popular com as seguintes características de destaque: "lusobrasileiro, leigo, medieval, social e familiar" estando presente com grande força nos primeiros momentos da colonização, possuindo forte influências de confrarias e irmandades e não distinguindo atividades culturais particulares da população da religião oficial. $\mathrm{O}$ catolicismo tradicional assumia um papel de um
} 
Pode-se perceber claramente em comunidades como São Luiz do Paraitinga, ainda atualmente, uma clara distinção entre um catolicismo oficial divulgado pela Igreja Católica e uma manifestação bastante diferente, característica das camadas populares. Trata-se de um catolicismo doméstico que é semelhante ao catolicismo praticado pelos primeiros colonos e chefes de família, e liga-se diretamente à importância exercida pelas irmandades naquela época. Augustin Wernet aponta ainda a importância do Vale do Paraíba, uma região tradicionalmente muito católica para este catolicismo tradicional e cita o exemplo de ser essa uma região onde, em 1855, encontrávamos nada menos que cinqüenta e cinco confrarias, geralmente comandadas por leigos, com destaque para as de São Benedito, Nossa Senhora do Rosário e a do Santíssimo Sacramento. Esta última completou, no início de 2005 , duzentos anos em São Luiz do Paraitinga. ${ }^{272}$

Nas festas religiosas regionais podemos encontrar de maneira clara a força desse catolicismo popular, recheado de particularidades locais. É bastante presente a relação devoção-promessa, como já apontado na menção ao pensamento de Marcel Mauss, na Festa do Divino quando se destaca uma ligação direta entre o indivíduo e o sagrado, sem a intermediação da Igreja oficial.

Laura de Mello e Souza ao discutir de maneira brilhante essas especificidades, típicas do catolicismo popular, abordando as práticas de feitiçaria e de religiosidade de uma forma mais ampla no Brasil Colonial ${ }^{273}$, atenta para aspectos fundamentais de uma conduta religiosa típica dos devotos do Divino luizense no decorrer da sua história. Quando falamos que a população brasileira, nos primeiros anos da colonização portuguesa, adotava práticas singulares em sua relação com a religião devido a uma dificuldade de controle dos agentes eclesiásticos sobre a população, devemos adicionar a questão dos desafios postos pelo novo continente. Comumente esquecemos que a própria religião trazida, mesmo com todo seu discurso e institucionalização, não era nada mais que um forte

\footnotetext{
verdadeiro mosaico de influências e atitudes comumente distantes das orientações da Igreja e em oposição a uma nova postura que a instituição católica tentaria imprimir futuramente, para Azzi o catolicismo renovado: "romano, clerical, tridentino, individual e sacramental". Riolando Azzi em $O$ catolicismo popular no Brasil. Petrópolis, Vozes, 1978, p 9 apud Augustin WERNET. A Igreja Paulista no século XIX. São Paulo: Editora Ática, 1987, pg 17.

272 Augustin WERNET op cit, pg 21.

${ }^{273}$ Em seu livro - SOUZA, Laura de Mello e. O diabo e Terra de Santa Cruz: feitiçaria e religiosidade popular no Brasil Colonial. São Paulo: Companhia das Letras, 1986.
} 
processo de absorção de variados rituais pagãos e, na própria Europa, foi bastante lento o processo de uniformização tridentina. ${ }^{274}$

Assim, quando transferimos essa dificuldade de uniformização para um local como o Brasil, com novos grupos sociais em interação e adicionando-se a questão de um controle frouxo da Igreja sobre seus fiéis, é de se imaginar o quanto o catolicismo adquiriu uma feição especial. Sem se esquecer ainda de como a escravidão fundiu elementos típicos das religiões africanas aos ritos europeus, Laura de Mello e Souza sintetiza bem a questão:

'Eivado de paganismos e de 'imperfeições', (...), o catolicismo de origem européia continuaria, na colônia, a se mesclar com elementos estranhos a ele, multifacetados muitas vezes, como a própria religião africana transmigrada". 275

E era geralmente através das irmandades que o catolicismo popular perpassava a sociedade brasileira. João José Reis mostra o destaque das irmandades, que espelhavam a sociedade política de sua época. Embora tivessem como requisito a questão étnica em sua organização, bens materiais muitas vezes eram sinônimos de participação nas irmandades, e como é de se imaginar, principalmente, as ligadas à elite e à etnia branca, eram muito influentes em suas decisões, possuindo papel fundamental no dia-a-dia da sociedade. Mas todas irmandades possuíam grande inserção no cotidiano da população. As irmandades estritamente populares, como as de origem negra, poderiam até estar alijadas de discussões políticas importantes, porém, eram grandes propagadoras de um modo de vida típico do que hoje ainda chamamos de "catolicismo popular". Oposição a regras de conduta da metrópole, religiosidade pautada em crenças particulares e de várias origens, eram apenas algumas das características presentes nas tantas festas de santo realizadas. Aliás, esta atividade era o ponto máximo da atuação de todas as irmandades. ${ }^{276}$

\footnotetext{
${ }^{274}$ Ibid pg 86-100

275 Ibid, pg 94

${ }^{276}$ João José REIS em A morte é uma festa: ritos fúnebres e revolta popular no Brasil do século XIX. São Paulo: Companhia das Letras, 1991.
} 
Quando escutamos um depoimento como o de dona Maria Antonia ${ }^{277}$, membro da congada de Lorena/SP e presente, segundo ela, pela vigésima terceira vez na Festa do Divino de São Luiz do Paraitinga, percebemos claramente a devoção típica de uma religião que, fugindo do controle da Igreja, não deixa de ensejar uma prática singular:

“(...) não conseguiria sair de casa se não conseguisse ter vindo mais um ano para esta festa pois não sou eu quem dança em louvor ao meu santo guardador São Benedito e ao Divino e, sim, todos meus ancestrais que vieram lá da África. (...) Sei que tenho uma vida difícil e faz tempo que estou desempregada, mas na hora das necessidades é só pedir ao Espírito Santo que ele se encarrega de levar até Deus pessoalmente (sic) o meu pedido e logo tudo se ajeita. (...) Sou tranqüila que quando morrer São Benedito e o Divino cuidarão de meus pecados e me ajudarão no mundo melhor".

Esta fala primeiramente reforça a forte presença e importância dos populares em uma festa a princípio de elite. Permite reforçar a hipótese da incorporação do rei Congo na festa do Divino de São Luiz do Paraitinga ser provavelmente fruto da presença marcante das congadas que vinham dançar na festa, alçando o rei do Congo a uma espécie de ícone dentro da festa do Divino.

O outro ponto que gostaria de ressaltar da fala de dona Maria Antonia é a preocupação dos devotos com o destino após a morte. Preocupação apontada por João José Reis como um dos exemplos desta relação de "barganha" entre as pessoas e o sagrado no interior deste catolicismo tradicional. ${ }^{278}$ Quando descrevemos a relação direta que existe para os sujeitos da zona rural entre a sua prenda, recolhida pela bandeira do Divino, e o sucesso posterior de sua colheita, estamos nos referindo à mesma crença que Laura de Mello e Souza detectava nos habitantes da colônia quando doenças e forças da natureza eram males impossíveis de se banir com a ação humana. A fé era a única possibilidade de uma espécie de "negociação" onde ao se oferecer algo ao sagrado, muitas vezes bens materiais, poderia se neutralizar os

\footnotetext{
277 O depoimento de Maria Antonia Brito, 67 anos, natural de Lorena e membro da Congada de São Benedito, desta mesma cidade, toca pela devoção ao Divino e a São Benedito, em uma relação distante do que prezaria a atuação de um fiel seguidor dos dogmas católicos. Foi registrado no mês de maio de 2006, momentos antes da procissão de encerramento da Festa do Divino Espírito daquele ano.

${ }^{278}$ João José Reis op cit, pág 59.
} 
malefícios, em uma relação chamada pela autora de "contrato do tipo 'toma lá-decá' ", 279

As procissões realizadas nas várias festas de santos em São Luiz do Paraitinga, são também exemplos claros de manifestação desse catolicismo popular. Desenvolve-se na organização de uma procissão, apesar da presença do padre, todo um ritual especial que foge do seu alcance. Os próprios devotos são os grandes responsáveis pela preparação da procissão, levando inclusive muitos objetos que referenciam seus desejos pessoais, como as bandeiras do Divino que carregam chupetas, fotografias, fazendo diretamente a ligação entre os mundos do sagrado e do homem.

Como parece ser inevitável, são constantes os conflitos entre o pároco e os participantes das manifestações populares na organização dos aspectos considerados profanos mas festas religiosas. O exemplo mais claro dessa relação conflituosa na festa do Divino de São Luiz foi a grande interrupção que ela sofreu entre 1913 e 1943. A vinda de um padre italiano em 1912 para São Luiz, padre Ignácio Gióia, trouxe sérias conseqüências para a organização dos festejos. Já no ano seguinte ao de sua chegada, alegando falta de respeito para o que considerava sagrado, decide suprimir a festa do calendário religioso local, persistindo por quase três décadas apenas as cerimônias litúrgicas nos dias em que se realizavam as apresentações populares, típicas da festa luizense desde a época colonial. O padre combatia em suas declarações "os jogos, as danças, as diversões, as cavalhadas, as congadas, moçambiques, jongo e até mesmo a farra que se transformou a distribuição do afogado",280. $^{\text {. }}$

É necessário atentar para uma festa luizense nesse momento de interrupção, já bastante diferente do momento áureo que viveu principalmente em meados do século XIX. A elite agrária local, que constantemente bancava a festa tornando-a muito atraente para a Igreja, havia entrado em forte crise juntamente às dificuldades encontradas pela lavoura cafeeira. A agricultura do município voltava à sua

\footnotetext{
${ }^{279}$ Laura MELLO e SOUZA op cit, pg 109.

${ }^{280}$ Padre Ignácio Gióia apud Judas Tadeu de CAMPOS, op cit, pg 56.
} 
característica "pré-café" com forte cunho doméstico e pequenos excedentes comerciais $^{281}$.

Trata-se ainda de um momento histórico em que cada vez mais se intensifica o crescimento das cidades e a constituição de um ideal de sociedade urbana que constantemente, como o estereótipo do "Jeca Tatu", fazia uma distinção de valores entre o homem rural - sinônimo de ingenuidade e até de vagabundo- e o homem urbano. Tudo isso, paralelo no campo religioso, a muitos esforços para se consolidar um determinado tipo de catolicismo "romanizado" no Brasil, possibilitando um maior controle da Igreja sobre os eventos organizados pela população de maneira autônoma. A diminuição da importância da atuação das irmandades e a sua própria extinção são elementos que completam o panorama que desafiou a realização da festa luizense no começo do século XX.

Entretanto, como tantos outros desafios, não foi suficiente para brecá-la. Seu retorno, em 1943, demonstra a dificuldade de controle da cultura popular. Encontramos um dado interessante para a volta da festa nos documentos do Departamento de Imprensa e Propaganda do ano de 1942, e ele pode ter pesado na decisão do Monsenhor Gióia em restaurar a estrutura tradicional da festa com todos seus grupos, distribuição de comida, brincadeiras entre outras manifestações:

“ (...) ressaltamos a importância dos governantes brasileiros em ressaltar os valores nacionais e a cultura de nosso povo (...) festas religiosas como a do Divino Espírito Santo são marcas já de nosso povo e devem ser incentivadas..." 282

Não consegui comprovar que este documento tenha efetivamente chegado a São Luiz do Paraitinga. De qualquer forma, sabemos da força dos argumentos que ressaltavam a defesa do nacional de maneira ufanista naquele momento histórico. Chama a atenção nesse documento do DIP a adoção da festa do Divino como

\footnotetext{
281 Mesmo se lembrando que São Luiz nunca foi grande produtora de café, com o deslocamento das produções cafeeiras para o Oeste Paulista o papel de entreposto comerciale as lavouras produzidas para sustentar este comércio caem em desuso voltando-se à prática de subsistência.

${ }^{282}$ Circular do Departamento de Imprensa e Propaganda do Governo Vargas distribuída às prefeituras municipais in Mattos Ibiapina, Júlio de. O Brasil de ontem e o de hoje. [Rio de Janeiro]: Departamento de imprensa e propaganda, 1942
} 
nacional, mesmo sabendo da sua marcante feição portuguesa ${ }^{283}$. Vale lembrar que esta era muito representativa, naquele momento, e em todo o país configurava-se uma estratégia persuasiva na busca da valorização do nacional.

Não se pode, entretanto, deixar de levar em consideração que depois de anos de sacerdócio no Brasil o próprio Monsenhor Gióia poderia ter contribuído para o ressurgimento da festa do Divino já apreendendo um pouco acerca das lógicas locais e revendo muitas das posições ortodoxas com as quais chegara.

O que na verdade considero mais importante de toda essa história é que tendo sido interrompidas as manifestações profanas da festa por três décadas, se alijou toda uma geração da participação desses eventos. Entretanto, como explicar a volta dos mesmos eventos com toda sua força quando a Igreja os permite novamente em 1943? Derrubar formas de representação do "mundo" do povo configura-se tarefa muito mais árdua que se possa imaginar. Suas estruturas estão dispersas no dia-a-dia, na visão de mundo das pessoas, e a simples proibição de uma apresentação não desconfigura esse "arcabouço cultural” que está por trás.

O caso da interrupção da festa do Divino de São Luiz do Paraitinga e a atuação do monsenhor Gióia e da população ante esta situação é exemplar para relacionarmos com toda aquela discussão teórica feita inicialmente: a festa do Divino local transformou-se num palco privilegiado para a população luizense poder expressar e manter um modo de vida pautado nos padrões de uma religiosidade colonial - pensada sempre nos padrões doméstico e numa relação direta com o sagrado - versus uma grande ruptura representada pelo padre italiano e radical que seria o monsenhor Gióia - este agora símbolo da romanização e do catolicismo ortodoxo buscando como primordial uma supressão dos aspectos populares da festa. E a vitória do popular representada na retomada integral das manifestações populares no interior da festa a partir do ano de 1943 é muito representativa.

Gostaria assim, no capítulo seguinte, de discutir questões contemporâneas no interior da festa diretamente relacionadas a todos os eventos e situações presentes

\footnotetext{
283 Mesmo reafirmando a miscigenação cultural da festa do Divino luizense a influência portuguesa, especificamente, é a mais marcante. As misturas com paganismos vêm de muito antes e não alteram as feições portuguesas. Mesmo as danças populares - como as folias - e o afogado têm muitas influências de Portugal. Talvez o maior traço mestiço na festa do Divino seja mesmo o da forte presença das congadas e do rei Congo no caso luizense - consideradas a partir de um dado momento já que não estiveram sempre presentes na festa.
} 
neste histórico e nas situações singulares que privilegiei até então. Procurarei mostrar que desafios contemporâneos, longe de decretar a falência das manifestações populares presentes no Divino, podem ser a passagem para novas formas de representação ou mesmo reafirmação das anteriores. 


\section{Capítulo IV - A relacão da festa do Divino de São Luiz do Paraitinga}

\section{com as atuais transformacões na sociedade local}

Espero ter ficado clara nos capítulos anteriores, a importância da história singular de São Luiz do Paraitinga para a constituição e consolidação de uma tradição secular como as manifestações em louvor ao Divino Espírito Santo. Afirmo isto novamente aqui, justamente com o intuito de reconhecer o "senso comum" presente nas diversas reportagens, análises e pesquisas existentes sobre a cidade, qualificando-a como uma das localidades brasileiras mais "tradicionais" $284 \mathrm{em}$ seu modo de vida e em seus costumes. ${ }^{285}$

É importante reconhecer que por possuir uma mentalidade política predominantemente avessa às transformações muito abruptas, - a cidade de São Luiz do Paraitinga é marcada por um forte assistencialismo na administração pública. Questões adicionais que contribuem para a manutenção da tradição são uma história econômica de dificuldades imensas, não permitindo grandes projetos de crescimento do município, e um forte controle do clero católico no dia-a-dia das pessoas. É verdade que esse controle do clero é cada vez menor mas, ainda mais presente nesta cidade que na maioria das cidades brasileiras. Em suma, a cidade de São Luiz do Paraitinga acabou constituindo durante toda a sua história uma identidade muito forte, cuja tônica é sempre a de ressaltar o passado e o que ficou marcado como resistente e tradicional ante as novidades.

No vale do Paraíba, a cidade ganhou destaque mesmo sendo um dos municípios mais pobres. ${ }^{286} \mathrm{O}$ grande número de construções históricas, na sua maioria tombadas pelo CONDEPHAAT/SP, acabam gerando ainda uma espécie de "clima histórico" onde o que aparece como mais importante é sempre o antigo. Ressaltar sua história é um orgulho imenso para o luizense que não consegue

\footnotetext{
${ }^{284}$ Tradicional entendido como mantenedora de tradições culturais, diferentemente do sentido negativo de uma cidade oposta a inovações como o termo "tradicional" muitas vezes nos sugere.

${ }^{285}$ São Luiz do Paraitinga é cada vez mais tema de reportagens nos principais meios de comunicação da região. Na imprensa durante o período de pesquisa desta dissertação 83 reportagens incluindo os jornais "Vale Paraibano", "Folha de São Paulo" e "O Estado de São Paulo" (período agosto 2006 a janeiro 2008).

${ }^{286}$ O canal de televisão regional Vanguarda (da Rede Globo de Televisão) possui em suas estatísticas a cidade de São Luiz do Paraitinga como a que é mais citada em reportagens e documentários proporcionalmente a população das cidades. Home page www.vanguardatv.com.br no dia 17 de janeiro de 2008 .
} 
encontrar importância na situação da sua cidade dentro do cenário econômico do país:

“ Não importa muito, pra gente que vive em São Luiz, as mudanças do governo, as crises das bolsas, essas coisas que falam na televisão. Aqui na nossa querida cidade, nós vivemos das coisas que nós plantamos, das lições dos fazendeiros do passado, dos favores dos vizinhos, da Igreja, da prefeitura. Podemos não ter riqueza mas dormimos sempre orgulhosos e agradecendo a Deus por morar nessa cidade e cada vez mais vem gente da cidade grande tentar aprender com nossas histórias. "287

A fala do sr. Nelson Alvarenga - por sinal, um músico luizense muito participativo nas manifestações populares - é emblemática nessa função primordial da história local como força de resistência. Ela é explicativa também, de ser essa uma das únicas localidades de nosso país que ainda mantêm muitas tradições populares. Mas, será então que só cidades de certo modo "atrasadas" economicamente, isoladas, mantêm tradições por mais tempo?

É fácil concluir que isso não é suficiente. Embora em São Luiz do Paraitinga a manutenção de costumes por muitos anos seja marca muito forte, já foram reportados diversos casos nos capítulos anteriores de influências externas, transformações, assim como foi frisado que a cultura não é algo estático, ao contrário, tem na plasticidade sua principal marca.

Gostaria de analisar neste capítulo as transformações mais recentes que a sociedade luizense vem enfrentando e que acabam modificando, de maneira direta, a festa do Divino Espírito Santo na atualidade. Um crescimento vertiginoso do turismo, a mudança do perfil do habitante cada vez mais urbano, a perda de poder da Igreja Católica, a mudança gradual de uma concepção política assistencialista são alguns dos temas que vão de encontro à necessidade de desmistificar a imagem de uma cidade extremamente tradicionalista como justificativa para uma questão muito mais ampla e complexa: a importância de São Luiz do Paraitinga está na constituição de uma sociedade que valoriza o coletivo, que absorve o novo sempre pelo seu "crivo" de uma identidade local muito forte.

\footnotetext{
${ }^{287}$ Entrevista com o sitiante do bairro do Mato Dentro seu Nelson Alvarenga no dia 18 de dezembro de 2007.
} 
"O tempo da história oscila entre o que Fernand Bradel chamou a "longa duração" e esta cristalização que Marc Bloch prefere chamar o "momento" mais do que o acontecimento e onde coloca como mediatriz a 'tomada de consciência': ' o historiador não sai nunca do tempo (...) ele considera tanto as grandes ondas de fenômenos aparentados, que atravessam lado a lado a duração, quanto o momento humano onde essas correntes se cessam no potente nós das consciências. "288

A cantora paulistana Suzana Salles recentemente foi curadora da I Semana da Canção Brasileira - realizada em novembro de 2007. O evento foi organizado pelo governo do Estado de São Paulo e pela Natura Cosmética, reunindo grandes nomes da música popular brasileira. Em seu texto de abertura do evento, com o olhar de uma pessoa estrangeira, contudo que frequienta muito São Luiz do Paraitinga e muito bem a conhece, Suzana Salles define claramente essa realidade de influência mútua entre tradição e criação da sociedade luizense, e o impacto na consciência da mesma. Muito emblemática na defesa de suas características próprias, locais, mas também sempre "antenada" às influências externas, Suzana Salles tem como tema a música popular. Entretanto, podemos transferir diretamente à cultura popular de uma forma mais ampla o seu raciocínio. Detecta, no cenário musical, uma realidade idêntica a que encontraremos nos exemplos dados adiante presentes nas festas do Divino contemporâneas. Aliás, uma realidade ainda muito valorizada por ser tradicional, mas, marcada cada vez mais pela mudança do público que a freqüenta e da mudança de mentalidade dos próprios luizenses que a organizam:

"São Luiz do Paraitinga é exemplo de vivência cultural para o Brasil, principalmente no campo da música popular brasileira. Num olhar de longe, ela parece viver do passado. O casario histórico, a praça com coreto ajardinado, a Igreja Matriz, tudo, à primeira vista, inspira nostalgia, supõe serestas para donzelas nas janelas dos sobrados dos tempos do Imperador. Pois São Luiz do Paraitinga, sem deixar de lado as reminiscências, sem deixar de cultuar seu rico passado, consegue celebrar seu presente em festas, religiosas ou não, e ainda projetar seu olhar para o futuro, recriando suas antigas tradições e inventando outras mais novas. Terra do grande compositor Elpídio dos Santos, autor de grande parte das trilhas sonoras dos filmes de Mazzaropi, a cidade reafirma sua tradição musical através de nomes atuantes da música brasileira, como o grupo Paranga, o compositor Galvão Frade, o poeta Marco Rio Branco e, mais recentemente, com a jovem banda Estrambelhados. É

\footnotetext{
${ }^{288}$ LE GOFF, Jacques. Prefácio in BLOCH, Marc. Introdução à História. Publicações Europa-América LTDA, Portugal, 2007. página 25.
} 
reconhecida no Vale do Paraíba como um grande celeiro de instrumentistas, tendo sua Fanfarra Monsenhor Ignácio Gióia como tri-campeã nacional. A cidade destaca-se no cenário nacional, também, pelo animado Carnaval que promove todos os anos, onde os luizenses compõem e celebram marchinhas próprias, cantadas a plenos pulmões pelas ruas enfeitadas de chita e fitas coloridas. Os blocos tradicionais atendem por nomes curiosos como Maricota, Pai do Troço, Juca Teles, Espanta-Vaca, entre muitos outros. Dessa maneira séria de brincar, desta capacidade de reinventar-se na criação e manutenção das tradições, a cidade surge como cenário ideal para a I Semana da Canção Brasileira. Bem vindos a São Luiz do Paraitinga."289

\section{1 - A situação econômica atual da cidade e o êxodo de mão-de-obra}

São Luiz do Paraitinga continua a representar muito pouco nas estatísticas econômicas do país e mesmo de sua região valeparaibana. Se no século XX atingiu números de certo destaque na produção cafeeira ${ }^{290}$ e uma respeitável produção da pecuária leiteira, hoje, mantém trabalhando no campo cerca de 1200 pessoas $^{291}$, ou seja, pouco mais de $10 \%$ de sua população de 10496 habitantes. ${ }^{292}$ E mais importante do que o número de pessoas trabalhando, é a ínfima produção segundo as estatísticas do próprio IBGE.

Na zona urbana, é marca indiscutível a dificuldade de emprego e de inserção no mercado de trabalho dos jovens. Sustentado sobretudo pelo setor de serviços, o campo de trabalho para os jovens dificilmente apresenta perspectivas de crescimento profissional na cidade. E falo isto, neste momento, por ter sido essa justificativa econômica uma das mais encontradas nas diversas entrevistas onde buscava explicações para uma menor participação da juventude nas festas religiosas locais. A

\footnotetext{
289 Texto de abertura da I Semana da Canção Brasileira distribuída em folders de divulgação durante o evento realizado em São Luiz do Paraitinga de 19 a 25 de novembro de 2007. Pode ser encontrado na íntegra no site www.semanadacancaobrasileira.com.br

290 Discutimos no capítulo II os limites dessa riqueza.

291 Dessas 1200 segundo o IBGE apenas 199 não possuem parentesco com o produtor, demonstrando ainda uma forte vocação de agriculturas familiares e de subsistência inclusive. Fonte: IBGE, Resultados da Amostra do Censo Demográfico 2000 - Malha municipal digital do Brasil: situação em 2001. Rio de Janeiro: IBGE, 2004.

${ }^{292}$ Fonte: IBGE, Resultados da A mostra do Censo Demográfico 2006.
} 
fala do jovem José Edimar da Silva Rego ${ }^{293}$, do Bairro do São Sebastião, ilustra bem isto:

"Talvez eu seja um dos poucos dos jovens da minha turma que ficaram morando em São Luiz e olha, que não é fácil! Eu tenho sorte que minha mulher também trabalha no Programa Saúde da Família no meu bairro e nos ajuda. Porque só assim para continuar vivendo aqui. $\mathrm{Na}$ verdade, eu poderia ter ganho muito mais dinheiro se fizesse como muitos amigos que foram morar em Taubaté, São Paulo e, hoje, têm bons empregos. Só fico feliz em ter ficado, pois mesmo vivendo com menos dinheiro, vivo muito bem aqui. São Luiz é uma cidade privilegiada e como você me perguntou da festa do Divino, eu, mais do que eles, posso participar mais ativamente dela. Quem sabe o Divino não cuida melhor da gente, né!!!”294

Muitos partilham da realidade retratada pelos que não tiveram a possibilidade, ou mesmo não quiseram, continuar vivendo em São Luiz do Paraitinga como José Edimar. Com isso, acabam se distanciando cada vez mais de muitas manifestações da cultura popular e perdendo muito daquela ligação tão forte da identidade luizense. De um modo geral, a maioria dos luizenses que vivem em grandes centros mantém sua devoção ao Divino, mas, é justamente a distância que não permite a participação dessas pessoas nos eventos que antecedem a festa, por exemplo. Como sempre, reafirmamos que a festa é muito simbólica, muito ritualística e essas pessoas acabam se sentindo menos importantes por não participarem dessa preparação.

Mesmo com as dificuldades decorrentes da distância, durante os dias da festa do Divino, muitos ex-moradores de São Luiz do Paraitinga fazem o esforço que for possível para participarem das festividades. É o caso de Antonio Carlos Santos, luizense, 32 anos, morador da cidade de Lorena:

“ Nem que seja pra ver o afogado ou a procissão, eu dou um jeito de aparecer na cidade. Só se não puder mesmo por questões de trabalho, porque, do contrário, eu largo tudo. Esse ano mesmo eu vim sozinho e deixei a mulher trabalhando e olhando o filho." 295

\footnotetext{
${ }^{293}$ José Edimar trabalha no comércio na zona urbana de São Luiz do Paraitinga, no cargo de balconista, salário de cerca de $\mathrm{R} \$ 600,00$ e reside junto com a esposa e filhos no bairro do São Sebastião percorrendo cerca de 40 quilômetros de ida e volta para seu trabalho. Chama a atenção em seu perfil ser também um dos líderes da capela de seu bairro com forte atuação religiosa.

294 Entrevista realizada no dia 19 de janeiro de 2008.

${ }^{295}$ Entrevista realizada em maio de 2007 (durante o sábado da festa do Divino).
} 
Entretanto, imagino que o caso de Antonio Carlos não deve ser a norma e, vários ex-participantes das festividades em louvor ao Espírito Santo acabam, sim, perdendo aquela forte ligação simbólica devido à distância. É inegável que as dificuldades de sobrevivência de muitos luizenses vivendo em sua cidade natal faça com que o problema de renovação dos grupos folclóricos, das pessoas diretamente envolvidas na preparação do "afogado", da procissão, fique ainda maior.

Mas não podemos deixar de registrar que esse quadro de penúria econômica tem começado a mudar nos últimos anos. O crescimento do turismo tem possibilitado o aumento de recursos no município. Basta consultar o orçamento da arrecadação da prefeitura municipal, pois constatamos o tamanho da mudança nos últimos $\operatorname{anos}^{296}$ :

Tabela 04 - Orçamento de arrecadação da prefeitura municipal de São Luiz do Paraitinga/SP

$(2001 / 2007)$

\begin{tabular}{|c|c|}
\hline ANO & Arrecadação \\
\hline 2001 & $\mathrm{R} \$ 6.314 .100,00$ \\
\hline 2002 & $\mathrm{R} \$ 7.370 .000,00$ \\
\hline 2003 & $\mathrm{R} \$ 8.408 .900,00$ \\
\hline 2004 & $\mathrm{R} \$ 9.865 .500,00$ \\
\hline 2005 & $\mathrm{R} \$ 11.916 .740,00$ \\
\hline 2006 & $\mathrm{R} \$ 13.300 .000,00$ \\
\hline 2007 & $\mathrm{R} \$ 15.757 .400,00$ \\
\hline
\end{tabular}

Fonte: Setor de tributos da Prefeitura Municipal de São Luiz do Paraitinga/SP

E mais do que analisar o orçamento do poder público e perceber este crescimento vertiginoso principalmente após a cidade ser elevada à categoria de estância turística em 2003, qualquer pessoa que freqüente a cidade há algum tempo, confirma uma mudança muito grande do que conhecemos por "progresso" no tocante à infra-estrutura local. Cada vez nos deparamos com mais pousadas, hotéis, restaurantes, lojas de artesanato local. Os prédios e casas do centro histórico estão, na maioria, restaurados e muito melhor cuidados que algumas décadas atrás.

Dessa forma, uma melhora considerável pode, sim, ser percebida na maioria dos índices oficiais do IBGE da cidade de São Luiz do Paraitinga ${ }^{297}$. Entretanto, isso

\footnotetext{
296 Orçamento da Prefeitura Municipal da Estância Turística de São Luiz do Paraitinga anos de 2001 a 2007 disponibilizado para consulta no setor de tributos da prefeitura.

${ }^{297}$ Dados disponibilizados no site www.ibge.gov.br/cidades/default selecionando-se o município de São Luiz do Paraitinga.
} 
não é suficiente para evitar o êxodo da população luizense para outros municípios e, mais marcante ainda no caso de nosso tema, uma mudança do perfil do luizense tem se acelerado: cada vez mais urbano, cada vez mais velho ${ }^{298}$, cada vez mais escolarizado, menos católico e com famílias reduzidas. ${ }^{299}$

E isso, obviamente, acaba por provocar muitas transformações no dia-a-dia da comunidade e, conseqüentemente, na realização das festas do Divino Espírito Santo. Ao mesmo tempo em que o turismo e o aumento de divisas permitem determinados tipos de apoio - como a compra de uniformes, salários aos foliões do Divino -, ele acaba criando uma espécie de "risco" de transformar muito da espontaneidade das manifestações populares em cultura de entretenimento.

\section{2 - Uma cidade cada vez menos isolada}

A situação geográfica de São Luiz do Paraitinga a beneficiou conforme a maioria das análises, em manter muitas tradições culturais. Mesmo com a posição estratégica de apoio a tropas e carregamentos nos séculos XVIII e XIX em uma região de vegetação tão inóspita sua marca era do isolamento as outras cidades. Além do que acabou tendo ficado de fora do eixo de crescimento industrial do vale do Paraíba paulista no século XX, mantendo um modo de vida diferenciado, longe dos padrões homogeneizantes do mundo moderno. Um isolamento analisado positivamente pela sua própria população e pela grande maioria de pesquisadores e freqüentadores da cidade. Será então que o turismo, única saída econômica vislumbrada atualmente, poderia colocar essa história cultural em risco?

Embora muitas pessoas na cidade pensem dessa forma a questão, com certeza ela é muito mais complexa e temos que levar em conta alguns fatores que, na minha opinião, contam a favor de uma saída otimista diante dessa nova realidade, desde que bem gerida. Primeiramente, reafirmamos tanto as características de plasticidade

\footnotetext{
${ }^{298}$ Mesmo com o êxodo dos jovens em busca de empregos melhores a cidade tem recebido muitos novos moradores da terceira idade contribuindo para um crescimento de $37 \%$ pelo censo de $2006 \mathrm{em}$ comparação com 2000 na faixa etária acima de 60 anos. Fonte www.ibge.gov.br/cidades/default selecionando-se o município de São Luiz do Paraitinga.

${ }^{299}$ Censos de 1991, 2000 e 2006 . Fonte www.ibge.gov.br/cidades/default selecionando-se o município de São Luiz do Paraitinga.
} 
e transformação da cultura popular que seria extremamente incorreto não aguardar seus mecanismos de adaptação frente a este novo processo.

Por exemplo, se muitos grupos acabam desaparecendo - principalmente pela ausência de renovação, falta de interesse da juventude frente a influências dos meios de comunicação da atualidade -, outros ressurgem simplesmente pelo reconhecimento que as pessoas de fora da cidade os transmitem ao conhecê-los. E esse reconhecimento transcende em importância as ajudas financeiras que são também cada vez mais freqüentes. Se o mundo atual é considerado hostil às manifestações populares pela valorização da individualidade, é verdade também que nunca surgiram tantos programas de apoio à cultura popular: sejam os projetos apoiados pela lei Rouanet, iniciativas do poder público municipal ou diversos apoios diretos de pessoas jurídicas e físicas dentro de uma espécie de "movimento de valorização das manifestações culturais em nosso país". Obviamente, uma realidade longíssima do ideal, porém, muito melhor que há alguns anos atrás.

Ao ver aquele grupo folclórico formado pela sua família em um programa de televisão, ou uma reportagem de um jornal de destaque, muitos jovens modificam sua concepção: aquilo que até então poderia representar algo "atrasado", "careta", "por fora" - só para citar alguns dos termos que escutei durante as entrevistas - passa a ser algo de extrema importância, trazendo inclusive um status social que esses buscavam por outras vias. A fala do jovem Luiz Carlos, 19 anos, a seguir, coletada na festa do Divino de 2007, representa muito bem essa questão:

“ Tem horas que tenho que assumir que tenho vergonha de usar essas roupas de congada, mas, isso é uma coisa que, se não usar, é como se não fizesse parte de minha família. Eu conheci pouco o meu avô, mas, ele já falava do pai ou 'vô' dele, que fundou esse nosso grupo de congada de Taubaté. (...) $\mathrm{Na}$ verdade, eu acho até que já foi pior, pois quando eu tinha treze, quatorze anos, meus colegas de Taubaté tiravam o maior sarro de mim. Uma coisa é se apresentar na festa do Divino, se sentir importante, ter um monte de gente tirando foto, entrevistando como você, saindo na Globo... outra, é ter que vestir essa roupa e ficar na praça Epaminondas de Taubaté num 'sabadão', de noite, quando toda a galera está pronta pra noitada. "300

\footnotetext{
${ }^{300}$ Entrevis ta realizada em maio de 2007 (durante o sábado da festa do Divino) com Luiz Carlos da Silva, 19 anos, membro desde os seis anos de idade do Grupo de Congada do Alto do Cristo de Taubaté/SP.
} 
O crescimento do turismo talvez seja o dado mais impactante na realidade da festa do Divino luizense atual. A fala desse rapaz é clara ao demonstrar um aspecto positivo desse fenômeno. O sentimento da importância da participação e a existência de um público que valoriza o popular são pontos fundamentais à perpetuação de manifestações como a do grupo do qual faz parte. Analisando as atas de Leitura Comunitária do Plano Diretor Participativo da cidade $^{301}$, chamou muito minha atenção a seguinte situação: em todos os bairros - urbanos ou rurais - quando se perguntava quais os problemas e/ou soluções locais quanto ao advento do turismo na cidade de São Luiz do Paraitinga, as respostas foram positivas, no máximo, com críticas visando ao aperfeiçoamento do ramo turístico e, nunca, sua negação. Destaco isso pois é muito comum encontrarmos discursos onde a opinião acerca da relação do turismo com cultura popular é de que trata-se de uma relação extremamente degradante. Eis algumas das respostas do plano diretor local que dizem o contrário:

- Primeiramente, o bairro do Verdeperto - considerado o mais elitizado da cidade:

- Desenvolvimento da Política de Desenvolvimento para os pontos turísticos melhor aproveitamento e proteção;

- Tombamento pelo Iphan: criação de metas para o tombamento, respeitando as normas exigidas;

- Desenvolvimento do calendário turístico-/ maior identificação de produtos turísticos;

- Política mais elaborada para o turismo, meta a médio e longo prazo, privilegiando qualidade do projeto.

- bairro do São Sebastião - a maior produção agrícola da cidade situa-se nessa localidade:

\section{- Desenvolvimento do Turismo rural;}

- O distrito de Catuçaba:

- Incentivar o turismo rural na zona de amortecimento do ParqueEstadual, sendo esta uma alternativa econômica para o proprietáriorural;

- Viabilizar, incentivar e normatizar o turismo ecológico no município;

- Inclusão do Distrito em festas e comemorações.

\footnotetext{
301 O Plano Diretor Participativo da Estância Turística de São Luiz do Paraitinga pode ser consultado na sede da prefeitura Municipal, sito a Praça Dr. Oswaldo Cruz, 03. Sua síntese também está presente no site www.saoluizdoparaitinga.sp.gov.br.
} 
- Por fim, a opinião do Grupo Gestor e dos moradores do Centro da cidade:

- Criação de mecanismos para fomentar o desenvolvimento ecologicamente sustentável:

- Turismo;

- Mercado para os produtos locais (exportar) - artesanato e música

- Agronegócio "familiar" - produtos orgânicos, beneficiamento (laticínio), indústrias artesanais;

- Criar uma "marca luizense" para agregar valor, capacitar, buscar mercado fora da cidade, etc;

- Associar e cooperar com os produtores para agregar valor, certificar maior poder de negociação (Ex.: "selo de garantia");

- Gerar benefícios para que os comerciantes locais adquiram produtos locais (Ex.:

diminuição de impostos);

- Incentivar e incrementar o turismo com atividades. Ex.: passeios a cavalo (cavalgada), passeios de barco e bote pelo Rio Paraitinga (cidade);

- Valorizar os produtos e a cultura local para o Turismo;

- Sazonalidade do fluxo do turismo e de eventos - "planejamento" - com maior organização, divulgação (com antecedência) e "políticas de turismo";

- Maior otimização da utilização do mercado;

- Atração e opção de lazer noturno;

- Cadastrar e tombar as fazendas históricas e ruínas;

- Resgatar e tombar a antiga Trilha do Ouro, entre São Luiz de Paraitinga e Ubatuba;

- Tombamento do município pelo IPHAN;

- Criação de parcerias para projeto de fiação subterrânea;

- Abertura das igrejas e museu para os turistas, com o acompanhamento dos guias;

- Construção de portal nas entradas da cidade;

- Necessidade do Posto de informação turístico melhor estruturado;

- Projeto municipal para melhorar os passeios públicos (fiscalização da prefeitura);

- Instalação de monitoramento eletrônico da cidade;

Deparamo-nos, dessa maneira, com uma realidade muito propícia ao crescimento do turismo na cidade de São Luiz do Paraitinga. A começar por uma população com forte perfil receptivo ${ }^{302}$ e que deseja, em sua maioria, o crescimento desse ramo como uma saída econômica para cidade. A elevação do status do município como uma localidade de destaque no cenário cultural brasileiro graças ao avanço do turismo, com certeza, é mais um fator determinante para essa situação de aceitação por parte da população.

\footnotetext{
${ }^{302}$ Sempre reafirmada pela imprensa como uma cidade muito hospitaleira, acho importante lembrar que era local de apoio às tropas, ao escoamento das produções de monocultura dos séculos XVIII, XIX e XX, deixando marcada na população um perfil receptivo. Perfil esse fundamental ao desenvolvimento do turismo.
} 
E o crescimento tem sido, sim, muito rápido. Embora não haja estatísticas oficiais sobre o número de visitantes na cidade a cada ano, é fácil perceber, por vários motivos, o crescimento rápido e consecutivo. Desde 2001, ano em que a cidade ganhou sua primeira pousada com classificação aceita pelo Guia 4 Rodas ${ }^{303}$ principal publicação brasileira de roteiros turísticos - chamada Pousada Ápice, o número de leitos recomendados por esse mesmo guia saltou de $40^{304}$ para $180^{305}$ Consultando o diretor de turismo local, Eduardo Coelho, tive a confirmação de que nenhum estabelecimento comercial do ramo de hotéis e pousadas da cidade acabou encerrando ou mesmo diminuindo suas atividades. Ao contrário, foram sempre reformas de expansão ou abertura de novos estabelecimentos:

" A cidade tem se estruturado de forma cada vez melhor no ramo de atendimento ao turista. Obviamente que nossa realidade é a de um município de dez mil habitantes. Entretanto, como você me perguntou, as pousadas, hotéis só têm crescido. Não há registro de qualquer fechamento ou diminuição de atendimento, pelo contrário, outros ramos de apoio como restaurantes, lanchonetes, agências de turismo também têm crescido. (...) E o mais importante desse crescimento turístico é a mudança positiva do perfil do público visitante. É cada vez maior o número de pessoas interessadas em cultura, pesquisadores, moradores de grandes centros do país como São Paulo e Rio de Janeiro. O único caso, à parte, é o Carnaval que traz à cidade milhares de pessoas de diversos interesses, inclusive, o predativo." ${ }^{306}$

Esse público cada vez maior de pessoas de fora da cidade em sido muito importante, na minha opinião, como uma espécie de "injeção de legitimidade" para os membros dos grupos folclóricos em um mundo dito "moderno" e propenso a não valorizar eventos populares como a Festa do Divino. Tem crescido muito ultimamente, também, o intercâmbio cultural de São Luiz do Paraitinga. São exemplos as constantes apresentações de grupos locais em eventos da Secretaria de Cultura do Estado - como a já consolidada exposição "Revelando São Paulo"307 -, nas unidades da rede SESC em todo o estado de São Paulo ou mesmo em projetos paralelos como a elaboração de um livro que se encontra em fase final de construção

\footnotetext{
${ }^{303}$ Guia 4 Rodas. Editora Abril: São Paulo, 2001.

304 Ibid página 809.

305 Guia 4 Rodas. Editora Abril: São Paulo, 2007, página 835.

${ }^{306}$ Entrevista realizada em março de 2008 com Eduardo Coelho, atual diretor de Turismo municipal.

307 Uma mostra da cultura popular do Estado de São Paulo realizada anualmente no Parque da Água Branca em São Paulo/SP. Reúne a apresentação de grupos folclóricos, literatura popular, culinária, artesanato e afins.
} 
denominado “De São Luiz a São Luís”, buscando as similaridades culturais entre o município que estudamos nesta dissertação e a capital do estado do Maranhão. ${ }^{308}$ Durante as festas do Divino mais recentes, a cidade tem recebido além dos tradicionais grupos folclóricos de municípios vizinhos - marca em toda a história da festa -, a apresentação de grupos de pesquisadores da cultura nacional, muitas vezes ligados a instituições de ensino superior como a própria USP ${ }^{309}$.

\section{3 - Riscos trazidos pelo turismo e o surgimento da população de "segunda residência".}

Até agora foram apontados muitos pontos positivos do avanço do turismo na cidade, destacando-se o benefício econômico e de valorização da cultura local. É fundamental discutir conjuntamente algumas outras questões relacionadas ao crescimento do número de visitantes que causam impacto direto e, nem sempre positivo, no dia-a-dia da comunidade luizense.

Embora tenha ficado claro, durante as entrevistas desta pesquisa, uma tendência de concordância positiva a respeito dos benefícios do turismo para a cidade, ainda muito se critica no dia-a-dia da comunidade esta nova situação que pode acabar por modificar, e mesmo descaracterizar completamente o modo de vida tão valorizado até então. Ao mesmo tempo em que representa uma possibilidade praticamente única de saída pelas dificuldades apresentadas na atualidade à sobrevivência da cultura local, se não organizada cuidadosamente e muito bem estruturada - com planejamento, estudos de impacto futuro - pode ser sim a confirmação de muitos argumentos que vislumbram uma decadência acelerada da cultura popular:

“ Embora eu possa vender cada vez mais os doces e queijos que eu produzo, eu me preocupo muito com essa 'gentarada de fora' que acaba fazendo a gente mesmo ter que modificar muito de nossa vida para atender a

\footnotetext{
308 Projeto idealizado pelo Grupo "Caxuera" - notável por trabalhos de valorização da cultura popular trabalhando na captação de recursos para projetos como o desse livro - sito no bairro de Perdizes em São Paulo, em conjunto com as prefeituras municipais das duas cidades envolvidas.

${ }^{309}$ Tem sido presença marcante nas últimas festas a participação dos pesquisadores do Celacc, núcleo de pesquisa ligado à ECA-USP e coordenado pela prof ${ }^{a}$. Drª . Maria Nazareth Ferreira.
} 
eles. Eu, agora, nem na missa de domingo vou mais! É um dos dias que mais vende nos comércios as coisas nossas da fazenda e tenho que vir trazer na cidade e entregar. Além do que vem, sim, muita gente boa, educada, mas, vem também muito ladrão. A cidade aparece toda hora na televisão... quem não vai querer roubar, ué?! "310

A fala do luizense João Daniel assinala vários pontos que são referências nas reclamações da maioria da população quando se queixa sobre o avanço do turismo. Por apresentar um estilo de vida muito próprio, onde a comunidade sempre foi pensada coletivamente, com um grande destaque aos acontecimentos da rua ${ }^{311}$, dos locais públicos, o simples aumento de pessoas oriundas de outras localidades faz com que muitas pessoas sintam-se "invadidas". E a mudança da rotina da cidade é, sim, algo a ser pensado com mais cuidado. O grande trunfo do turismo em São Luiz do Paraitinga é o da constituição de uma sólida tradição das manifestações ligadas à cultura popular. Caso a cidade não apresente mais o mesmo apoio e espaço para essas manifestações, pode não só colocar em risco a continuidade de muitos grupos populares e de um modo de vida diferenciado, como contribuir para a falência do próprio avanço turístico que se assenta - antes de qualquer coisa - sobre as tradições culturais e os eventos relacionados. A festa do Divino é um dos maiores exemplos de ocupação total de pousadas, hotéis e grande movimento de restaurantes e comércio do gênero.

A fala de uma outra luizense, Dona Afonsina da Conceição, é exemplar do comportamento acanhado de uma grande parcela da população luizense, queixosa deste novo público que freqüenta a cidade :

“Eu, que sempre vivi aqui em São Luiz, fico meio assustada com tanta gente diferente. Na festa do Divino mesmo, como você perguntou antes, até tinha mais gente, mas, era tudo da família da gente, conhecido de alguém, ou gente muito simples mesmo como a gente, povo da Igreja, sabe...? Hoje, quando saio com a minha bandeira na procissão, é um monte de gente tirando foto... Pra falar a verdade, nem tirar foto não é o pior, viu?... Eu fico mais

\footnotetext{
${ }^{310}$ Entrevista realizada em outubro de 2007 com João Daniel dos Santos, morador do bairro da Fábrica, zona rural de São Luiz do Paraitinga. Seu João Daniel vive hoje, segundo ele mesmo "da lavoura toda voltada à venda de produtos que tem aumentado muito com o turismo: verduras frescas, queijos, doces e alguns pequenos artesanatos".

${ }^{311}$ Utilizei muito como base referencial para entender a força dos acontecimentos em espaços públicos de São Luiz do Paraitinga a obra MATTA, Roberto da. A casa \& e a rua. Rio de Janeiro: Rocco, 1997, já citada no primeiro capitulo da dissertação.
} 
nervosa quando vem o povo e fica perguntando pra gente as coisas da festa, da nossa cidade e eu não sei responder! "’312

Transformar cultura popular em produto é, com toda certeza, um erro e um perigo muito grande. E embora não seja esse o caminho pregado pelo poder público e pela sociedade luizense até então, alguns fatos causam bastante preocupação. É cada vez mais freqüente em São Luiz do Paraitinga a apresentação de grupos como a folia de Reis em eventos totalmente deslocados de seu calendário religioso. No ano de 2005, por exemplo, a Folia de Reis de São Luiz do Paraitinga, do mestre José de Arimatéia, se apresentou durante o Festival Gastronômico da cidade ${ }^{313}$. Enquanto ela cantava em homenagem ao nascimento de Cristo em pleno mês de agosto, as pessoas comiam e bebiam nas mesas improvisadas na rua Coronel Domingues de Castro, sem qualquer identificação com as simbologias tão fortes presentes nas apresentações de stes grupos.

Mesmo as muitas iniciativas de apoio aos grupos folclóricos, têm que ser analisadas com certa cautela. A tendência cada vez mais da obtenção de patrocínio de grandes empresas, doando uniformes, comprando instrumentos, oferecendo infraestrutura nos dias da festa do Divino, tem que ser vista com precaução devido ao risco de descaracterização dos próprios beneficiados. A própria exibição de uma logomarca em um uniforme de uma congada ${ }^{314}$, por exemplo, parece colocar em risco toda aquela identidade constituída de uma tradição de ancestralidade, de autonomia, como discutimos no primeiro capítulo.

Durante os dias da Festa do Divino, embora seja tradicional a montagem de barracas que comercializam bebidas alcoólicas e lanches industrializados, estas possuem cada vez mais destaque visual ante os locais tradicionais de organização da festa. Seja pela exibição de faixas - coloridas e chamativas - sobretudo de marcas de

\footnotetext{
312 Entrevista realizada em maio de 2007 com Afonsina Conceição de Souza, 67 anos, moradora da zona urbana, no bairro de São Benedito. Dona Afonsina é minha tia mais velha e fiquei tocado pela sua queixa em ser questionada sobre as coisas da cidade. Na verdade era exatamente o que eu estava fazendo naquele instante, acredito ter sido ajudado pelo grau de parentesco facilitador, nesse caso, na relação com o entrevistado.

${ }^{313}$ Evento organizado pela associação comercial de São Luiz do Paraitinga, onde cada restaurante local comercializa suas especialidades culinárias em uma rua da cidade interditada especificamente para o festival.

${ }^{314}$ Exemplo hipotético embora não parecendo algo tão longe da realidade atual da festa do Divino luizense.
} 
cerveja, ou mesmo pelo impacto das barracas serem construídas em armações de metal, cada vez mais modernas e grandiosas.

Ao mesmo tempo em que a crescente procura por parte de pesquisadores, emissoras de televisão, jornais, permite à festa do Divino de São Luiz do Paraitinga um maior reconhecimento, contribuindo diretamente à renovação dos grupos folclóricos pelo sentimento de importância que assumem - como foi discutido há pouco -, eventos como a procissão do Domingo da Festa têm se transformado em uma aglomeração de fotógrafos e entrevistadores, causando constrangimentos e tirando a atenção de muitos eventos religiosos como no caso da procissão. A presença da reportagem da TV Globo na benção do afogado nas últimas festas acaba chamando mais a atenção dos participantes do que a presença do próprio pároco e seus auxiliares que estão ali justamente para legitimar a ligação com o sagrado tão marcante neste evento.

De forma alguma estou defendendo uma postura de hostilidade às influências externas aos membros da comunidade luizense, ou, de pessoas diretamente envolvidas nas festas do Divino. Pelo contrário, acho essa presença fundamental na situação da sociedade atual, contudo, é preciso um cuidado muito grande para que essa relação seja benéfica, de soma e não de descaracterização. Trazendo, sim, novas influências, mas, sempre negociadas com as já existentes no próprio "mundo do popular".

"Qualquer planejamento quanto a atividade turística deve considerar os seus atrativos como algo em movimento - sejam eles museus, casarões, cachoeiras, artesãos, músicos - que se relacionam com o meio, interagindo de forma que o que está vivo não seja morto pelo isolamento histórico-material. Ao mesmo tempo que se busca o que, enfim, é a identificação do patrimônio com o homem, está se fazendo de forma robusta um patrimônio, ou seja, de torná-lo significativo para moradores e visitantes (...) Identificar o patrimônio para com a sociedade e dessa maneira, instituí-lo de valor tal, que nenhuma condição de ordem conjuntural poderá destituí-lo daquilo que realmente significa. "315

\footnotetext{
${ }^{315}$ GUIMENEZ, Denis Maracci. "São Luiz do Paraitinga por ele mesmo: aspectos históricos, tradição e cultura IN FERREIRA, Maria Nazareth (org) A tradição e seu significado para o turismo cultural: o vale do Paraíba. São Paulo: CELACC, 1999, páginas 98 a 105.
} 
Se a cidade conseguir encontrar o caminho pregado pelo autor Guimenez, neste trecho reproduzido acima, não haverá o que temer quanto ao avanço do turismo. Entretanto, a fala do prefeito municipal Danilo José de Toledo logo à frente - embora tenha sido construída para valorizar imensamente o turismo e o papel que atribui a sua administração a esse rumo adotado pela cidade - deixa escapar muitas queixas comuns à maior parte da população e que demonstram a necessidade de muito amadurecimento da sociedade luizense nas diversas relações sociais que o turismo atrai. Queixas essas, que têm de ser analisadas na busca de um ideal de assimilação da população conjuntamente e identificando-se com os visitantes:

“ Hoje, como prefeito municipal da Estância Turística de São Luiz do Paraitinga, posso me orgulhar de ter contribuído a um novo rumo econômico para a cidade. (...) Assumo ter sido um processo muito difícil e que demandou muita negociação política nas diversas esferas do poder, além de uma forte resistência dos próprios luizenses inicialme nte. Como você me perguntou da importância do desenvolvimento do turismo para a economia e cultura local, foi muito difícil conseguir demonstrar para a população os benefícios do turismo. Sempre se ressaltavam aspectos negativos, com destaque ao aumento da violência. Entretanto, sofremos de uma tendência nacional de aumento de furtos, pequenos delitos, e não foi exatamente o turismo o causador. (...) Agora o mais importante disso tudo foi ter permitido que a população enxergasse em seu patrimônio histórico e cultural valor. Hoje os luizenses falam dele com orgulho e se queixam de uma coisa muito interessante: muitas pessoas de outros municípios, que acabaram comprando imóveis na cidade, são na maioria das vezes, muito bem intencionadas no trato com o patrimônio, mas, para a maioria da população, seriam como estrangeiros tomando a posse do patrimônio local ..." "316

Logicamente há uma tentativa de chamar a atenção para todas as dificuldades enfrentadas pela população e que seriam superadas com a implantação de uma política efetiva de turismo na cidade, aliás, um dos maiores objetivos de sua administração. $\mathrm{O}$ aumento da criminalidade é, sem dúvida alguma, uma das maiores queixas da população. E justificar esse aumento - assumido pelo próprio prefeito na fala acima - apenas por explicações exógenas é, com certeza, insuficiente. Tanto falamos do aumento da exposição de São Luiz do Paraitinga na mídia nos últimos anos, a freqüência maior de turistas - muitas vezes das classes econômicas mais abastadas - o que acaba, sim, atraindo um número maior de criminosos. Nem por

\footnotetext{
${ }^{316}$ Entrevista com o atual prefeito municipal Danilo José de Toledo (PSDB) - administração 2000/2004 e 2004-2008 - no dia 10 de dezembro de 2007.
} 
isso defendo aqui uma opinião contrária ao turismo, apenas, identifico esta realidade do avanço do crime e acho extremamente necessárias medidas mais concretas do poder público no combate a ele.

Quanto à valorização do patrimônio que o turismo proporciona, isto é um fato consumado na cidade. É muito gratificante perceber uma mudança cada vez mais positiva da conservação do patrimônio histórico da cidade. E não basta citar apenas uma melhora econômica do município em índices como o IBGE que citávamos há pouco. Sem a consciência da população, de nada adiantaria. ${ }^{317}$ Programas sociais afirmativos têm sido implantados e contribuem para o fortalecimento dessa consciência de preservação, destacadamente o "Projeto Restauro", que capacita jovens luizenses nas técnicas de restauro com aulas práticas no próprio patrimônio local. ${ }^{318}$ Além de permitir um aprendizado sobre o sentido de um patrimônio que, muitas vezes, passa despercebido por muitos, forma vigilantes como o aprendiz Carlos Roberto:

" Esses dias, vi um grupo de meninos bêbados sujando a parede da capela das Mercês que eu mesmo tinha ajudado a pintar. Fiquei tão revoltado que fui na hora tirar satisfações com eles" ${ }^{\text {319 }}$.

Essa consciência de preservação do patrimônio físico, naturalmente se transfere a uma preocupação de manutenção de grupos folclóricos e festas religiosas, destacadamente, a do Divino Espírito Santo. Afinal o patrimônio imaterial é fator também primordial na constituição das identidades populares. Podemos afirmar que existe uma continuidade da busca muito forte de uma identidade cultural pelos munícipes. Essa consciência é um dos motivos primordiais da manutenção de muitas

\footnotetext{
317 Segundo o diretor de planejamento da prefeitura de São Luiz do Paraitinga, Benedito Candido de Toledo, desde 2000 a cidade teve apenas duas residências embargadas pelo CONDEPHAAT. E ambas por apresentarem projetos de reforma de descaracterização e não por má conservação. Um índice muito baixo por se tratar do maior conjunto arquitetônico tombado pelo CONDEPHAAT no estado de São Paulo.

${ }^{318}$ Um programa do Fundo Social de Solidariedade da Prefeitura Municipal de São Luiz do Paraitinga, implantado em 2002 e que seleciona jovens estudantes do ensino Médio, de baixa renda e desempenho exemplar nos estudos, para profissionalização nas técnicas de restauro do patrimônio histórico. Inicialmente o projeto foi realizado em parceria com a prefeitura de Santana de Parnaíba e já contou com o apoio financeiro do Banco Real nas reformas da Capela das Mercês e do museu Dr. Oswaldo Cruz.

${ }^{319}$ Carlos Roberto da Silva, 16 anos, membro do Projeto Restauro no ano de 2005-2006 em depoimento a um programa de rádio local: "Nas ondas da Paraitinga" no mês de novembro do ano de 2006. Arquivo da rádio comunitária Paraitinga 105,9FM.
} 
manifestações como aquelas que existem no interior das festas do Divino e que desaparecerem na maior parte das outras cidades da região e, do país como um todo.

Não queria deixar de registrar outro ponto, para mim muito importante nessa discussão, também presente na fala do prefeito Danilo José de Toledo, sobre os chamados "moradores de segunda residência". Precisamos apontar alguns pontos positivos e negativos dessa tendência cada vez maior na cidade. Ainda tomando o censo de 2001 como base uma vez que os dados do censo de 2006 não foram divulgados sobre a frequiência de ocupação nos municípios, já é grande a tendência das moradias não serem ocupadas por famílias residentes na própria cidade. Elas já ocupavam mais de $15 \%$ das estatísticas e essa tendência com certeza aumentou nos últimos anos:

Tabela 05 - Domicílios permanentes e de uso ocasional em São Luiz do Paraitinga (2001)

\begin{tabular}{|l|l|}
\hline Domicílios particulares permanentes - ano de 2001 & 2.992 domicílios \\
\hline Domicílios particulares de uso ocasional -ano de 2001 & 482 domicílios \\
\hline
\end{tabular}

Fonte: IBGE, Resultados da Amostra do Censo Demográfico 2000 - Malha municipal digital do Brasil: situação em 2001. Rio de Janeiro: IBGE,2004. Fonte: IBGE, Resultados da Amostra do Censo Demográfico 2000 NOTA : Informações de acordo com a Divisão Territorial vigente em 01.01.2001. ${ }^{320}$

São Luiz do Paraitinga é frequientada cada vez mais por famílias que nela passam fim-de-semana, feriados prolongados ou eventos realizados na cidade. Novamente a festa do Divino é um desses momentos em que a população da cidade aumenta consideravelmente. Mesmo não existindo estatísticas mais recentes a respeito dessa situação específica, é bastante visível esse aumento no fluxo de pessoas que ficam na cidade e modificam seu perfil. Trata-se, é bem verdade de um público, na sua maioria, interessado em cultura e que acaba por contribuir imensamente com o fortalecimento das manifestações culturais da cidade. Contudo a população, frequentemente, se queixa da perda de espaço ou representatividade.

\footnotetext{
${ }^{320}$ No Censo de 1991, o IBGE aprimora a definição classificando as residências secundárias como domicílios particulares de uso ocasional não restringindo esta condição a não presença do morador temporário. Assim, conforme a Sinopse Preliminar do Censo Demográfico de 1991 (IBGE, p.11), "considerou-se como de USO OCASIONAL o domicílio particular que servia ocasionalmente de moradia (casa ou apartamento), isto é, os usados para descanso de fim de semana, férias ou outro fim não remunerado".
} 
Contribuem, dessa maneira, de forma paradoxal ao fortalecimento da identidade cultural luizense: por um lado são impulsos de valorização, demonstrando muitos caminhos que a população local não percebe. Pelo outro, são desagregadores pelo simples fato de não serem considerados membros efetivos pela própria comunidade. Inclusive, em alguns casos, acabam defendendo pontos de vista que podem não ser os ansiados pela maioria da população mesmo que sejam essas experiências bem sucedidas em suas regiões de origem.

“Práticas socioeconômicas e, ainda, mudanças que se referem às questões psicológicas e do cotidiano da comunidade são atingidas em cheio com o crescimento da chamada 'segunda residência'. Tal processo, direta ou indiretamente, vai alterar valores, percepções, formas de sociabilidades, isto é, comportamentos das pessoas envolvidas e das que transitam, o que implica diferentes modos de se posicionarem sobre riscos e possíveis impactos socioambientais advindos do processo de transformação das práticas, dentre elas, as práticas turísticas, nesse espaço." ${ }^{321}$

\section{4 - As novas tendências religiosas locais e o impacto na festa do Divino}

Até agora muito falamos dos impactos da modernidade, o avanço do turismo, e da conseqüente mudança do perfil dos freqüentadores e organizadores da festa do Divino de São Luiz do Paraitinga. E torna-se insuficiente esta constatação sem a fundamental percepção da rápida mudança do perfil religioso do luizense, quiçá, do brasileiro como um todo.

Quando as pessoas abandonam São Luiz, assim como todas as cidades de perfil semelhante, sobretudo em busca de novas perspectivas de emprego, carregam todo seu repertório cultural conjuntamente. Como o ambiente, geralmente individualizado dos grandes centros - o principal destino -, não permite a manutenção de tradições coletivas como a de uma festa popular, esses sujeitos acabam substituindo seus símbolos e suas crenças por novas práticas que suplantem essa necessidade de alguma forma. As Igrejas Evangélicas, por exemplo, estão ganhando muito espaço atualmente, montando um discurso que supre muitas

\footnotetext{
321 SENA, Maria de Fátima Alves. QUEIROZ, Odaléia T. M. M.. Impactos ambientais e sócio-culturais do turismo de segunda residência: o caso de Ponta da Tulha, Ilhéus, BA. Caderno Virtual de Turismo ISSN:1677 - 6976 Vol. 6, $\mathrm{N}^{\circ} 4$ (2006).
} 
necessidades típicas desses sujeitos, desamparados no tocante às suas simbologias espirituais.

Em toda sua história, a cidade luizense foi sempre marcada por uma forte ligação com a Igreja Católica, freqüentada pela grande maioria da população. Conta o compositor local, Marco Rio Branco, que a força da Igreja Católica era tanta na cidade durante o prelado do Monsenhor Ignácio Gióia ${ }^{322}$, na primeira metade do século XX, que não era nem aceita a possibilidade de se pensar em aceitar outro culto religioso na cidade:

“ Conta o mestre Pedro que certa vez chegaram na cidade um grupo de jeovás para pregar, isso lá nas primeiras décadas do século. Mostrando sua autoridade, o Monsenhor Gióia simplesmente mandou apedrejá-los. Era totalmente inadmissível esse tipo de coisa na cidade. (...) O engraçado de tudo isso era que as pessoas embora tivessem um medo até da Igreja, sempre participaram de cultos paralelos, como os de origem negra ligados aos grupos folclóricos da própria cidade: jongos, congos, mocambiques." 323

$\mathrm{Na}$ atualidade, embora o domínio dos católicos seja muito forte na cidade, é notável o crescimento de outras religiões, sobretudo, as Igrejas Pentecostais. Nos últimos dois anos - durante a pesquisa - acompanhei a abertura de três novas Igrejas na cidade: Igreja do Evangelho Quadrangular; Igreja Adventista e Igreja Internacional da Graça de Deus. E todas atraíram muitos daqueles cidadãos que participavam ativamente das festas do Divino.

É o caso do sr. Bivá:

" Participei da Festa do Divino ativamente por mais de quarenta anos. Desde os dez, doze anos até os cinquienta (...) eu fazia de tudo um pouco, ajudava recolher prendas, ajudava cozinhar, servir o afogado entre muitas outras coisas. Hoje minha religião, da Igreja do Evangelho Quadrangular, não permite mais que eu faça isso. Mas eu acredito muito no Espírito Santo. Só não posso ir lá ajudar, eu não sou mais católico. (...) Respeito muito sim a festa e torço para o seu sucesso por muitos anos."324

\footnotetext{
322 É esse o mesmo padre citado no segundo capítulo que interrompeu de 1917 a 1942 a realização da parte profana da Festa do Divino.

323 Entrevista com o compositor Marco Rio Branco em janeiro de 2008. Músico e escritor este é considerado um dos ícones da cultura letrada da cidade. Muito interessante é sua ligação também íntima com os membros da cultura popular, demonstrando o quanto essa divisão comum entre elite e popular não ocorre com tanta rigidez na cidade.

${ }^{324}$ Entrevista com o sr. Bivá em novembro de 2007. Ele não quis revelar seu nome de forma alguma, mesmo depois de trinta minutos de conversa. Embora tenha descoberto seu nome de verdade preferi respeitar sua vontade, constando apenas no meu arquivo pessoal da pesquisa seus dados.
} 
Considero este trecho do depoimento do sr. Bivá exemplar desta nova situação de muitas pessoas na cidade em relação à festa. Muitos não participam mais dela. Contudo, o respeito e a veneração ao Divino ou à festa em si, se mantém, mesmo que a distância e sem participação em seus eventos. Algo fundamental à continuidade da mesma.

Nem é preciso reafirmar tanto como a perda de fiéis do catolicismo é um fenômeno nacional. E, mesmo sem pesquisas estatísticas sobre a questão, é facilmente perceptível a mesma realidade detectada pelo instituto Datafolha, citada logo abaixo, em São Luiz do Paraitinga:

"Segundo pesquisa Datafolha realizada em 2006 e 2007, existem hoje no Brasil menos católicos do que há 10 anos. Em dezembro de 2006 o número de católicos era em torno de $74 \%$ diminuindo atualmente esse percentual para 64\%. O número de evangélicos pentecostais, por sua vez, ao contrário, aumentou passando de $11 \%$ em 1996 para 17\% atualmente." 325

Mais importante que simplesmente perceber um dado estatístico de diminuição do número de católicos, gostaria de destacar uma espécie de "nova situação de hostilidade do mundo moderno" como um grande desafio a ser enfrentado pela doutrina tão conservadora da Igreja Católica na atualidade. Com a sociedade cada vez mais secular, chegamos a uma situação que impacta diretamente nessa tão divulgada diminuição da participação popular nas festas do Divino. Por mais que se possa contra argumentar que as festas do Divino de São Luiz do Paraitinga recebam ainda muita gente, é inegável que há uma grande diminuição do público de fé.

Um fato social incontestável dos países ocidentais de tradição cristã na atualidade é essa crise representada pela "metamorfose do sagrado",326, um termo proposto pelo autor Velasco para dar conta da queda da prática regular das religiões tradicionais, da adoção cada vez maior de práticas oriundas de outras tradições espirituais, do surgimento e o avanço de novos movimentos religiosos e, ao mesmo tempo, do crescimento da indiferença religiosa. As estatísticas - como a do instituto Datafolha citada acima - sempre afirmam a existência de uma linha ascendente no

325 "Diminui o número de católicos no Brasil". Caderno Cotidiano, Jornal Folha de São Paulo. São Paulo, 06 de maio de 2007.

326 "Metamorfose do sagrado" é um termo criado por MARTÍn VELASCO, Juan. "Metamorfosis de lo sagrado e futuro do cristianismo". Cuadernos aqui y ahora 37. Santander: Sal Terrae., 1999. 
número de católicos não atuantes na atualidade também. Desta forma, o fator religioso tem passado ao segundo plano, com o aprofundamento da secularização. Cidades como São Luiz do Paraitinga, é bem verdade, acabam ainda mantendo muitas tradições religiosas e uma participação mais homogênea da população no diaa-dia religioso. Contudo, muito aquém da situação de décadas atrás.

Uma questão interessante neste quadro e que pode ajudar na explicação da manutenção das comemorações do Divino com certa força no momento de esvaziamento da Igreja Católica, é a opção do que Martín Velasco chama do "believing without belonging". 327 Ou seja, uma festa que sempre foi marcada por uma espécie de independência religiosa dos fiéis frente à instituição católica em toda sua história, encontra sim espaço para manutenção de suas práticas. Permite mesmo que pessoas como o senhor Bivá, hoje, praticante de outra religião - contrária a qualquer simbologia como as presentes na festa do Divino - continue, a distância, acreditando nessa manifestação.

Monsenhor José Eugênio de Faria, pároco em São Luiz do Paraitinga de 1992 a 1997, é considerado pela população luizense, atualmente, um dos personagens mais importantes na valorização das festas do Divino na cidade. Durante sua atuação em São Luiz, realmente não encontrei quaisquer registros de conflitos mais acirrados da Igreja com a população e os grupos populares diretamente envolvidos nas festas. Hoje, respondendo pela parte administrativa da diocese de Taubaté, ocupando o cargo de vigário-geral - espécie de "vice-bispo" como ele próprio definiu -, apresenta uma séria preocupação com o futuro da festa, com o processo de secularização da sociedade como um todo, criticando duramente o avanço das Igrejas Evangélicas. Na sua visão, uma situação muito hostil às manifestações populares:

“Eu tenho esperança que a festa do Divino de São Luiz do Paraitinga se manterá por muitas e muitas décadas ainda porque ela tem uma raiz muito forte. Quando as coisas possuem tradição de verdade, não é fácil ser abalada, não. As coisas podem mudar... e isso é natural... mas, a essência se mantém. O que me traz mais preocupação hoje em dia é a falta de compreensão das igrejas evangélicas, que estão crescendo especificamente com um discurso que não respeita essas manifestações que necessitaram de séculos para se consolidarem. Com um discurso muitas vezes apelativo a bens materiais e

\footnotetext{
${ }^{327}$ Numa tradução básica: crer sem pertencer à Instituição religiosa. O autor sempre cita a expressão em inglês - "believing whithout belonging". Vide MARTIN VELASCO, idem nota anterior.
} 
situações de dificuldade pontuais na vida das pessoas pregam um discurso de praticamente enfrentamento a tradições e cultos a símbolos religiosos, marca das festas do Divino. A religiosidade é muito forte em atos muitas vezes desconsiderados pela gente mesmo da Igreja, como a devoção religiosa dos que dançam a congada",328

Logicamente que o monsenhor Eugênio está defendendo a instituição que ele próprio representa. Da mesma forma que discutimos inicialmente a existência de diversas formas de catolicismo - sendo o praticado em São Luiz uma vertente bastante tradicional, muitas vezes autônomo à Instituição - as Igrejas Evangélicas da cidade não representam essa hostilidade imensa. O próprio padre assume, no fim de sua fala, uma ausência de reconhecimento por parte da Igreja Católica das manifestações populares - nenhuma novidade quando observamos o histórico da festa.

Portanto, não podemos simplesmente atribuir ao avanço de outras religiões, decadências no interior da festa. Há muitas questões internas como estamos observando. Contudo, é, sim, um fenômeno muito importante para a festa do Divino na atualidade, uma real diminuição do público participativo nos eventos religiosos, tendência acelerada pela troca de religião de muitas pessoas, da mudança do perfil dos católicos ou mesmo de um aumento da secularização da sociedade.

Em São Luiz do Paraitinga, embora com uma experiência mal sucedida no ano de 1997, quando o pároco enviado para ser o sucessor justamente do Monsenhor Eugênio era ligado à Renovação Carismática ${ }^{329}$ e não conseguiu se estabelecer na cidade pela incompatibilidade de idéias com a população, hoje, cada vez mais, fiéis católicos luizenses têm aderido a $\mathrm{RCC}^{330} \mathrm{e}$, acabam se afastando de muitos eventos ligados à chamada parte "profana" da festa.

Embora a própria população com um número imenso de reclamações para a Diocese tenha conseguido afastar rapidamente da cidade o padre Benedito Hércules

\footnotetext{
${ }^{328}$ Entrevista com o Monsenhor José Eugênio de Faria - o Padre Eugênio para os luizenses - em janeiro de 2008.

329 São muitos freqüentes os embates internos na Igreja Católica entre a Renovação Carismática e os grupos folclóricos/ religiosos ligados à uma prática religiosa mais tradicional.

330 Sigla usada para designar a Renovação Carismática Católica, ala nascida nos EUA na década de 1960 e expandida em uma velocidade incrível para o restante do mundo. Está baseada, definindo bem sumariamente, sobre um discurso da necessidade de reafirmação moral no mundo moderno, focando, destacadamente, uma aproximação maior da juventude à religião católica, e, para uma maior propagação buscando fazer uso de todos meios de comunicações possíveis do mundo atual. BRENDA, Carranza. Renovação carismática católica : origens, mudanças e tendências. Aparecida, SP : Santuário, 2000
} 
em $1997^{331}$, o crescimento de tendências religiosas católicas distantes daquela concepção de um catolicismo mais tradicional, intimamente ligado a simbologias e manifestações advindas das camadas populares, tem causado impactos diretos no perfil dos eventos católicos presentes na festa do Divino.

Por mais que muito se defenda o isolamento característico de São Luiz do Paraitinga, é impossível fugir de uma realidade comprovada pelos principais estudiosos religiosos do país, da mudança de perfil da população no tocante à religião e a crescente secularização é também realidade nesta localidade. ${ }^{332}$

\section{5 - O crescimento da interferência do poder público nas festas atuais}

Ao pesquisar as festas do Divino no Brasil, foram vários os pontos-chave para se basear na delimitação da sua formação, destacadamente a tradição da fertilidade e da ligação específica com o sagrado pela religiosidade popular, advindos de práticas medievais e espalhadas pelo mundo e pela história. Mas foi somente no decorrer da pesquisa que percebi um outro fator de supra importância: a função de contestação social presente nos eventos relacionados às festas do Divino realizadas em nosso país.

Um dos vários exemplos que poderiam ser citados, provando a constante busca de controle social pelas elites brasileiras - desde as festas do século XVIII e XIX há essa preocupação- foi a proibição, em São Luiz do Paraitinga inclusive, da visitação às cadeias durante a distribuição de alimentos pela possibilidade de exemplo subversivo que pudesse conceber. Mesmo os processos de incorporação de rituais pagãos por parte da Igreja Católica, representam, antes de vontade própria, mecanismos de controle sobre um grupo que prima pela autonomia e isenção dos típicos controles hierárquicos.

\footnotetext{
${ }^{331}$ Contam os luizenses que o momento crucial para o rompimento da população com o padre Benedito Hércules aconteceu justamente durante a festa do Divino de 1997, quando ele impediu a entrada de grupos de congada e moçambique no interior da Igreja Matriz por considerá-los "católicos impuros" suas próprias palavras - pela miscigenação de suas formações religiosas.

${ }^{332}$ Ver por exemplo PIERUCCI, Antonio Flávio. "Bye, bye Brasil - o declínio das religiões tradicionais no Censo 2000" in "Dossiê Religiões no Brasil", Revista do Instituto dos Estudos Avançados da USP, número 52. São Paulo: Universidade de São Paulo, 2004, página 18.
} 
Nessas últimas festas do Divino que acompanhei, é muito clara esta tensão constante entre o povo e as instituições representativas do poder. Atualmente, a prefeitura municipal vem assumindo muitas funções, antes destinadas à comunidade. Surge um novo ponto de tensão, mas que reafirma ainda mais o poder "subve rsivo" presente nas festas. A própria Igreja tem entrado em conflito em diversas situações com representantes do poder público municipal, além dos já tradicionais pontos de tensão com a população.

Acredito ser natural uma entrada da prefeitura municipal na disputa pela organização das festas pelo aspecto econômico que passa cada vez mais a girar em torno dela. Discutimos o crescimento do turismo em São Luiz do Paraitinga e a festa do Divino é um dos marcos fundamentais para uma cidade que prega o turismo cultural como principal trunfo.

Surge uma verdadeira "disputa" para organizar alguns eventos no interior da festa entre a prefeitura, a Igreja e os grupos folclóricos. No mês de março de 2005, em reunião realizada na prefeitura municipal onde se discutia o futuro do afogado na festa do Divino de 2005, o prefeito atual Danilo José de Toledo, foi bem claro em seus interesses presentes na festa ao dirigir-se ao atual pároco Gracimar de Souza:

“ (...) eu convoquei imediatamente esta reunião quando soube da iniciativa da Igreja de não bancar mais o afogado. Sei que a paróquia precisa de economias para gerir uma estrutura tão grande, mas nada justifica o fim de uma tradição que permitiu nossa cidade montar um repertório cultural tão importante. (...) Hoje, a festa do Divino, pertence ao calendário da secretaria estadual da Cultura e muitas pessoas vêm visitar nossa cidade justamente pela manutenção destas tradições. (...) Se lutei tanto por transformar São Luiz em estância turística é função do poder público a manutenção do afogado na festa do Divino e serei ajudado por estas pessoas que apresento ao senhor"333

A justificativa do pároco para a não realização do afogado na festa de 2005 foi bastante semelhante em muitos argumentos quando o Monsenhor Gióia interrompeu a parte profana da festa em 1913, acrescida agora da questão econômica:

\footnotetext{
${ }^{333}$ Esta fala registrada em março de 2005 foi extraída da reunião que contou com a presença do prefeito, do pároco Gracimar de Souza, dois ex-festeiros, o secretário de cultura municipal e uma comissão que se formou para assumir a realização do afogado na festa do Divino de 2005, atribuição até então da Igreja que justificou não ter mais condições financeiras de estruturar uma distribuição tão grande de alimentos.
} 
“ (...) Não faz sentido gastar tanto dinheiro numa distribuição de alimentos recheada de desperdício e acompanhada de exageros de bebida e desvirtuação da fé. Poderíamos com uma parte das prendas arrecadadas organizar a distribuição de cestas básicas que ajudariam na função social da festa por muito mais tempo que apenas dois sábados "334

Foto 06 - População saboreando o afogado (2008)



Fonte: acervo pessoal do autor

Talvez este clima de festa como destas pessoas na imagem acima durante o afogado na festa do Divino de 2008 seja interpretada pelo clero como um desvirtuamento de fé. Contudo, são eventos como a distribuição de comida, momentos fundamentais na consolidação das identidades da população crente e participante das festas do Divino da cidade. Além de representar claramente uma das formas de expressão do catolicismo pautado em padrões tradicionais, com toda aquela ligação direta entre a prenda e a retribuição da comida "abençoada", como já discutido nos tópicos anteriores.

Desta maneira, a força do próprio povo não permitiu a interrupção da distribuição do afogado durante o ano de 2005. Rapidamente se estabeleceu uma comissão com alguns ex-festeiros e membros organizadores das festas e, numa ligeira campanha foram arrecadas as prendas suficientes para a farta distribuição de

\footnotetext{
${ }^{334}$ Padre Gracimar de Souza em depoimento a reportagem da TV Vanguarda (afiliada da Rede Globo) no mês de março de 2005. Depoimento disponibilizado pelo site www.vanguardatv.com.br
} 
comida. A prefeitura municipal, nesse caso específico, representou uma importante função mediadora, embora o discurso oficial posteriormente tenha tentado capitalizar como trunfo político a manutenção de uma tradição.

Zinho Aurélio, ex-festeiro e membro da comissão que organizou o afogado de 2005, revela a força ainda presente na população luizense no tocante à organização das festas do Divino:

“Eu tentei avisar antes, mas como o padre não deu ouvidos nem a mim como a um grande número de pessoas, a nossa resposta está aí, na arrecadação. Nossa lista de prendas tem arrecadado mais donativos que a bandeira do santo, no curto espaço de tempo que nos sobrou para realizar o afogado". 335

Quanto à Igreja, nesse caso de 2005 repetia-se uma estratégia adotada já em 2003 e presente em outros momentos da história recente da festa. ${ }^{336}$. Tentando manter um maior controle, não foi escolhido um festeiro para organizar a Festa do Divino. Nomeou-se o CPP (Conselho Paroquial Pastoral) como o festeiro daquele ano. Os argumentos do então pároco Alaôr dos Santos, em 2003, são bastante semelhantes aos utilizados pelo padre Gracimar de Souza, criticando principalmente um desvirtuamento dos princípios religiosos e da necessidade de uma festa melhor administrada. É bem verdade que as últimas festas, refletindo a dificuldade de arrecadação de prendas da atualidade, têm gerado bem menos receita para a Igreja do que tradicionalmente acontecia. ${ }^{337}$ Agora é preocupante esse privilégio da necessidade de arrecadação surgir da própria Igreja também, ficando as tradições

\footnotetext{
335 Zinho Aurélio, 73 anos, foi festeiro do Divino em 1997 e um dos principais membros desta comissão em prol da realização do afogado na festa do Divino de 2005. O curto espaço de tempo que relata é o resultado da demora no impasse entre a Igreja, a prefeitura e a comunidade que só no fím de março decidiu pela realização do tradicional afogado em uma campanha paralela a arrecadação de prendas da bandeira oficial da festa que estava recebendo bem menos donativos pela opção de não realizar o afogado. ${ }^{336}$ Nos registros oficiais da Igreja - acervo local da Paróquia São Luiz de Tolosa - constam como festeiros do Divino comissões organizadas pela própria instituição nos seguintes anos durante o século XX: 1942 Monsenhor Gióia e Aguinaldo Salinas; 1946 Monsenhor José Maria e Congregação Mariana; 1950 Monsenhor José Maria e Comissão; 1957 Comissão da Igreja; 1969 Monsenhor Tarcísio de Castro Moura; 1972 Comissão da Igreja; 1982 Comissão da Igreja; 1999 Comissão da Igreja; 2003 Comissão do Conselho Paroquial e José B. Almeida e 2005 Comissão Paroquial, João Marcos e dona Didi. Gostaria de ressaltar que a Igreja local só possui a documentação com todos os festeiros ininterruptamente desde o começo do século XX graças ao acervo pessoal de dona Didi Andrade, personagem já discutida neste trabalho e de importância cultural fundamental na cidade.

337 A festa do Divino de 2008 foi uma exceção tendo gerado como receita líquida para a Paróquia de São Luiz de Tolosa aproximadamente $\mathrm{R} \$ 50.000,00$. Um valor que representa $20 \%$ a mais do que todo o dízimo arrecadado durante um ano segundo a secretaria paroquial.
} 
representativas da base de sustentação religiosa da população praticamente em segundo plano.

O padre Alaôr dos Santos foi outro que causou muita tensão com a população como o caso do padre Hércules citado anteriormente. Tentou por diversas vezes retirar grupos folclóricos das procissões em discursos que os classificava pejorativamente como "profanos". Suas homilias acusavam, por exemplo, os grupos de congada de possuírem ligações mais fortes com práticas de religiões africanas do que com as católicas. E, assim, deveriam ficar proibidos durante sua tutela de entrarem na Igreja no fim das procissões.

O grupo de foliões do Divino foi impedido também de recolher prendas nas festas de 2003 e 2004, pois o padre Alaôr acusava-os de extremamente dispendiosos para a festa. Coube à própria comunidade, com seus representantes ligados à Igreja nos bairros, a tarefa de recolher as prendas. Mais um fato muito representativo da situação contemporânea atravessada pela festa do Divino luizense: a racionalidade econômica tende a se sobrepor à lógica do consumo abundante adequada a uma comunidade de feições tradicionais. É a nova tensão social de uma comunidade tradicional - agrícola, de laços comunitários mais importantes que os individuais frente aos valores de comunidades de feições modernas - individualistas, monetárias, de mercado - trazidas, sobretudo, pelo avanço do turismo.

Voltando as tensões da Igreja com a comunidade é bem verdade que o atual pároco, Gracimar de Souza, embora tenha questionado a distribuição do afogado - e já retrocedeu na questão, pois ele tem acontecido normalmente nas festas posteriores a 2005 -, tem buscado diminuir os atritos com os grupos folclóricos. Levou os mesmos grupos de congada impedidos por seu antecessor a participarem normalmente da festa desde 2004, recebendo-os na procissão do domingo da festa e levando-os para dentro da Igreja, para uma participação efetiva na celebração que finaliza a festa.

Aliás, quando criticava excessos na distribuição do afogado, seus argumentos eram, sim, pertinentes em muitos pontos. Entretanto, transparecia claramente em suas atitudes, que a preocupação maior estava na tentativa de assumir um maior controle sobre a realização da festa. E feita de uma maneira muito mais bem- 
sucedida que os dois párocos que o antecederam - padre Alâor e padre Hércules pois não criava um enfrentamento direto com a população, sendo exemplo disso o restabelecimento da apresentação dos grupos de congada citado há pouco.

O afogado, na verdade, deve, sim, na minha opinião, ser repensado em muitos pontos para evitar o desperdício e melhorar as condições de higiene em seu preparo. É necessário pensar também que os problemas que cercam o afogado dizem respeito às transformações da sociedade e, portanto, dos significados da festa, embora na atualidade o afogado mantenha-se como um dos pontos de maior identificação para a comunidade luizense dentro da festa do Divino. Mesmo com todas as mudanças da sociedade, a interrupção da sua distribuição quebraria totalmente com um sentido que tanto ressaltei ao descrever a festa: a importância para os sujeitos que participam da festa do Divino, de ser esse um dos principais momentos para o cumprimento de promessas. E, mais ainda, a distribuição de alimentos transforma-se em um momento altamente simbólico, onde a comida do Divino é uma retribuição direta do sagrado pelas oferendas doadas.

É justamente essa força da comunidade que frequentemente tem entrado em conflito com o poder público que cada vez mais vem assumido as funções antes delegadas ou à Igreja ou à própria comunidade no decorrer da festa. São algumas destas atribuições assumidas pela prefeitura nas últimas festas: o transporte e alimentação dos grupos folclóricos durante a festa, as decisões sobre apresentações musicais, a montagem da infra-estrutura de barracas, a divulgação na mídia, entre outros pontos. Embora alguns desses apoios sejam muito importantes - atualmente se a prefeitura não bancar o transporte de grupos folclóricos de municípios vizinhos, eles não conseguem vir se apresentar -, é muito comum encontrarmos argumentos da comunidade contrários a muitas funções assumidas pelo poder público, acusandoo de estar atendendo a interesses eleitorais ou financeiros sem levar em conta a verdadeira importância das tradições populares.

O COMTUR - Conselho Municipal de Turismo - possuía em 2006 uma proposta que causou muitos desentendimentos em várias frentes na cidade e acabou sendo abandonado posteriormente: propunha uma forma de cobrança para que grupos folclóricos se apresentem fora do calendário das festas, recebendo grandes 
grupos de turistas. Uma proposta que visava transformar em entretenimento algo marcado por um forte sentido religioso e cultural, razão primordial na manutenção desses grupos na história da cidade.

As festas do Divino de 2006 e 2007 puderam representar ainda mais esse processo de aproximação do controle da prefeitura municipal sobre muitos eventos pelo simples fato dos festeiros terem sido respectivamente a família do prefeito municipal Danilo José de Toledo, em 2006, e a, do vice-prefeito Benedito Carlos, no ano seguinte. É importante anotar que ambos usaram justificativas de devoção pessoal para assumir a organização dessas festas. Enquanto o prefeito Danilo solicitou o cargo de festeiro para o agradecimento da cura de um câncer de bexiga, $o$ seu vice-prefeito a organizou pedindo a cura de seu filho que, infelizmente, faleceu um pouco antes da realização da mesma.

É interessante que mesmo sempre entrando em discordância com a prefeitura municipal em muitos pontos nas organizações das festas, a Igreja local não colocou nenhuma objeção em escolher como festeiros os principais representantes do poder público. Possivelmente, falou mais alto um pensamento prático na possibilidade da ampliação da infra-estrutura da festa, aliás, algo que realmente ocorreu e que confirma o "pano de fundo" político adjacente às festas .

Tanto em 2006 como em 2007 aumentou bastante o número de eventos culturais como a realização de shows musicais realizados durante a festa. Muitos deles conseguidos por intermédios políticos como a própria Secretaria de Cultura Estadual. Transporte de animais para a tradicional "cavalhada", mão-de-obra para a montagem de barracas, "pau-de-sebo", não tiveram problemas em ser feitas com toda a estrutura da prefeitura municipal voltada a auxiliar a realização das festas. E essa ajuda é importante desde que a organização por parte dos poderes públicos não transmita à população uma impressão da perda da autonomia do popular.

Um último exemplo semelhante ao anterior e detectado na escolha dos últimos festeiros, é a manutenção da necessidade de se exercer um status social elevado na comunidade - de forma idêntica ao que acontecia na festa no auge do ciclo econômico cafeeiro há cem anos atrás- para se obter o cargo de festeiro do Divino. Além dos exemplos dos festeiros de 2006 e 2007, ligados à política, no ano de 2008 a família Borriello de Andrade foi a responsável pela festa. E mesmo mais 
distante da política local, é também uma das famílias mais tradicionais e bem sucedidas economicamente da cidade.

O que é importante ressaltar nesse quadro é que mesmo tendo uma situação social de destaque, todas essas famílias possuem sim uma ligação direta com as tradições da festa e com a religiosidade local. A festa de 2008 acabou sendo uma festa grandiosa, não só pelos destacados contatos que a família Borriello de Andrade possui fora da cidade, angariando muitas colaborações para a festa luizense, mas, principalmente, pela forte ligação, participação e identificação com a festa em São Luiz do Paraitinga. Houve uma grande preocupação em organizar um evento que prezasse pelas tradições populares e, dessa forma, a população luizense acabou se envolvendo diretamente na organização dos eventos e de uma forma muito mais intensa que nas anteriores.

Todos os eventos organizados foram pensados sob uma forte preocupação de manutenção das tradições. A saída da folia do Divino logo após a festa de 2007 algo que não estava acontecendo nos últimos anos - é um desses exemplos. Além de permitir uma maior arrecadação é bastante natural que visitando praticamente a totalidade do município tenha surgido um maior envolvimento da comunidade com a festa. O afogado - muito bem organizado na sua preparação e distribuição - foi oferecido também na segunda e terça-feira como evento extra para que a população local pudesse ter um acesso mais fácil a ele. Foi retomada a distribuição de doces para as crianças, o almoço aos idosos na Vila Vicentina e realizados todos os eventos tradicionais das últimas festas.

Há ainda mais um aspecto muito positivo, tudo aconteceu sob a cuidadosa supervisão de Dona Didi Andrade, como já apontado, que há mais de meio século é uma das principais responsáveis pela organização das festas na cidade. Sua legitimidade perante a comunidade permitiu uma autonomia e um poder de agregação que há muito tempo não se via nas festas do Divino da cidade. É de se imaginar que muitas tensões persistiram como a Igreja não concordar com a distribuição de doces e de afogado em mais dois dias. Ou a contrariedade do pároco também pela presença do andor de São Benedito na procissão de encerramento da festa do Divino. Agora, o que chama a atenção, é que a vontade dos festeiros acabou sendo respeitada no fim, ficando marcada a importância dessas pessoas que mantém 
viva a memória e a tradição. A importância da legitimidade de Dona Didi frente a comunidade, a Igreja e ao poder público foi fundamental para a resolução das tensões.

É uma pena não poder analisar melhor esta festa tão representativa de 2008 pelo seu acontecimento ter sido concomitante ao término do prazo desta pesquisa. $\mathrm{E}$ mesmo com todas as preocupações em manter e reativar tradições populares pelos seus organizadores não podemos deixar de assumir que ela foi mais um passo nesta tendência de transformação da festa do Divino luizense em um grande evento de entretenimento. Contou com grandes shows, presença maciça da imprensa e de um público de turistas interessados no divertimento provavelmente maior que o público de fé tão característico do histórico das festas do Divino.

Como vem sendo apontado, não podemos deixar de considerar as transformações atuais da sociedade e do significado da festa para as pessoas. Dessa forma, muitas tradições estão mesmo sendo muito modificadas. Mas será que não seja essa a única possibilidade de manutenção na sociedade atual? Mesmo com toda essa tendência de "espetacularização" de um evento tão marcado por valores opostos ao entretenimento é muito representativo que, mesmo neste ambiente "hostil", tenha sido realizado no ano de 2008 uma festa do Divino com participação popular muito forte - as novenas estavam sempre lotadas e com muitas pessoas portando as bandeiras do Divino- e que a preocupação da continuidade de tradições populares seja ainda a lógica da maioria da população local neste novo ambiente. 


\section{Capítulo V - Consideracões finais: o surgimento de novas manifestacões populares na cidade}

É impossível aventar quaisquer projeções para o futuro da Festa do Divino de São Luiz do Paraitinga tendo aprofundado a percepção, durante esta dissertação, justamente da capacidade de transformação e adaptação do "mundo do popular" frente aos desafios a ele propostos. Mais do que chegar a conclusões, a pesquisa permitiu a abertura de novos campos de indagações e, espero ter apenas iniciado um trabalho sobre uma realidade tão rica e complexa.

Foi muito importante entender uma realidade estritamente local, considerando que as situações presentes na festa do Divino luizense faziam parte de um todo muito mais amplo, e que serviam justamente como um contraponto aos tantos discursos finalistas sobre o espaço do popular na contemporaneidade. Há que se ponderar ser questionável uma esperança inequívoca de que o popular continuará sempre existindo, possuindo uma força intrínseca e inabalável de adaptação às novas circunstâncias. Há muitos desafios que podem abalar sim suas manifestações. Contudo, ficou muito claro, não ser suficiente analisar o futuro da festa do Divino apenas observando o número de manifestações populares que possuía há dois séculos e o número atual, concluindo assim uma decadência irreversível. É preciso observar se a cultura popular não vem desenvolvendo uma de suas características mais marcantes: a capacidade de plasticidade e a conseqüente criação de novas formas de representação.

Embora não tenha sido possível, pelo tempo desta pesquisa, analisar detalhadamente outras formas de representação, é muito fácil perceber o surgimento de novos espaços de sociabilidade dos populares em São Luiz do Paraitinga e, que gostaria de ao menos citar nesta conclusão. Manifestações essas, de natureza totalmente diversa das presentes nas festas do Divino, entretanto, assentadas em signos, símbolos e concepções similares. Destaque para o Carnaval da cidade, considerado um dos mais originais do país, e que tem crescido exponencialmente nos últimos anos. Sua principal marca é a forte presença da oralidade, do repertório 
típico de marchinhas carnavalescas compostas - contemplando ritmos e temas locais - e da criação de bonecos e fantasias representativos de simbologias locais.

Dessa forma, se a influência do ritmo da congada e da forma de cantar das folias, a proeminência de personagens locais ante os tradicionais pierrô e colombinas, são a tônica do Carnaval da cidade nos dias atuais, como simplesmente concluir que a cultura popular tem perdido todo seu espaço na modernidade? É necessário admitir, sim, vários pontos, que já discutimos nos capítulos anteriores, configuradores de transformação e dificuldades colocadas aos grupos populares seja o aumento de interesses econômicos depois do crescimento turístico, seja a secularização da sociedade, entre muitos outros exemplos - porém, é muito forte a capacidade de resistência e dinâmica deles.

Acabei mudando totalmente a minha própria percepção durante a pesquisa, quando considerava ser absurda a apresentação de dois grupos de capoeira da cidade - uma manifestação que surgiu há menos de dez anos no local - ao lado de grupos tradicionais como as congadas e os moçambiques nas últimas festas do Divino. Como não perceber que os grupos de capoeira são frutos desta rica dinâmica de transformação dos populares?!

Sendo assim, eventos contemporâneos como o carnaval luizense - ou a SOSACI (Sociedade dos Observadores de Saci) -, surgem como elementos indicadores dessa característica transformadora e que permite enxergar o momento atual com a própria festa do Divino ganhando novos sentidos e possibilidades.

Lembrando das lições do Manual da História Oral do prof. José Carlos Sebe ${ }^{338}$, é difícil expressar o tamanho da satisfação pessoal proporcionada por essa pesquisa, seja pelo aprendizado pelo simples contato com um grupo tão especial da sociedade, pela mudança de concepção em minha formação como historiador e, ainda mais, pela satisfação da devolução social que já vem sendo proporcionada graças a essa pesquisa.

Foi muito gratificante ter participado como expositor da elaboração do segmento cultural do plano diretor da cidade, ou, ainda, ter proferido palestras em

\footnotetext{
338 Op cit: MEHYI, José Carlos Sebe Bom. Manual de História Oral. Edições Loyola, São Paulo, Brasil, $4^{\mathrm{a}}$ edição, maio de 2002.
} 
fóruns locais, contribuindo de alguma forma para a discussão da necessidade de políticas públicas de apoio e reconhecimento da identidade cultural tão forte de minha cidade. Agora, foi ainda mais "apaixonante”, poder levar discussões teóricas e acadêmicas para a rua, literalmente, tendo os rumos do estudo modificados constantemente pela opinião das pessoas que participam do dia-a-dia da comunidade.

A possibilidade da publicação de dois pequenos livros, como forma de retribuição à importância da atuação de Dona Cinira e Dona Didi Andrade para a minha pesquisa, foi uma das maneiras que encontrei de devolver tanta disposição em ajudar e o aprendizado que estas pessoas me proporcionaram. O primeiro, denominado “ A História Oral da 'Divina' senhora Cinira dos Santos”, foi fruto do trabalho de conclusão de curso da disciplina do prof. dr. $^{\circ}$ José Carlos Sebe cursada durante o início do mestrado -, sendo o resultado de uma série de entrevistas que contam a história de vida de uma senhora dedicada inteiramente às causas populares. Os momentos de elaboração e, principalmente, de entrega do material finalizado à Dona Cinira e sua família já seriam suficientes para compensar todas as dificuldades que enfrentamos em projetos como esse.

Ajudar na realização do sonho pessoal de Dona Didi Andrade de escrever um livro aos 79 anos, contando sua dedicação de mais de sessenta anos à festa em seu livro "Festa do Divino de São Luiz do Paraitinga: do sagrado às tradições" que acabou sendo publicado em edição da autora, foi mais uma confirmação do quanto pode ser gratificante nossa atuação como pesquisador da cultura popular.

Mesmo sabendo das limitações deste trabalho, sempre busquei o caminho apontado pelo prof. ${ }^{\circ} \mathrm{dr}^{\circ}{ }^{\circ}$ Nicolau Sevcenko em suas pesquisas - e ressaltado durante a banca de qualificação ${ }^{339}$ - de tentar enxergar nosso país e sua cultura de "baixo para cima”, identificando-se com o popular e se empenhando sempre em apresentar a festa do Divino a um público mais amplo.

A festa do Divino é historicamente marcada por uma espécie de função democrática e questionadora, ligada à fertilidade e à natureza, também expressando

\footnotetext{
$339 \mathrm{O}$ prof $^{\mathrm{o}}$. dr ${ }^{\mathrm{O}}$ Nicolau Sevcenko formou a banca de qualificação desta dissertação em setembro de 2007 ao lado do prof. ${ }^{\circ}$ dr. ${ }^{\circ}$ José Geraldo Vinci de Moraes. As observações de ambos foram de importância ímpar para a finalização dos trabalhos.
} 
de maneira representativa as tensões sociais. Se, sobretudo no campo ideológico, a festa acaba praticamente suprimindo funções de controle como da Igreja Católica e adotando o sagrado como um princípio fraternitário e igualitário, nos eventos desenvolvidos durante as festividades encontramos uma espécie de tensão entre os diferentes setores sociais. Constitui, no interior de um evento tão especial sob o ponto de vista cultural, uma espécie de "retrato" da representatividade política da sociedade.

Dessa forma, mesmo assumindo que a festa do Divino de São Luiz do Paraitinga tem se tornando cada vez mais elemento de políticas públicas e oportunidades econômicas, é sim ainda um caminho privilegiado para percebermos a incrível capacidade de reinvenção do popular no mundo moderno. Inclusive frente estes desafios do turismo e do capital.

\section{1 - O exemplo da música popular luizense}

Antes de apresentar os eventos da cultura popular que mais têm crescido na cidade - carnaval e SOSACI -, aliás, eventos que mesmo em novas linguagens trazem muito das características presentes nas festas do Divino, gostaria de fazer uma reflexão sobre um dos segmentos mais destacados dentro da cidade de São Luiz do Paraitinga, a música popular, reforçando o argumento das variadas formas de convívio e adaptação do popular no mundo moderno. A música surge como exemplo da possibilidade da adaptação de novos signos e símbolos convergentes, e, não opostos aos tradicionais.

Cursando a disciplina "História, memória e música popular: dilemas, impasses e possibilidades de construção do conhecimento histórico" ministrada pelo prof. $^{\circ}$ dr. ${ }^{\circ}$ José Geraldo Vinci de Moraes em $2006^{340}$, pude comparar um canto da folia do Divino, semelhante ao que apresentei no terceiro capítulo desta dissertação com a releitura musical de uma folia do Divino pelo grupo de maior destaque na cidade de São Luiz do Paraitinga: o Grupo Paranga. À primeira vista, possuía uma

\footnotetext{
340 A disciplina ministrada pelo prof. ${ }^{\circ}$ dr. ${ }^{\circ}$ José Geraldo Vinci de Moraes foi oferecida ao setor de pós graduação em história social da FFLCH-USP no primeiro semestre de 2006.
} 
opinião contrária a iniciativas deste tipo - farei uma síntese desta discussão que envolve também uma canção de um outro grupo do vale do Paraíba, Matuto Moderno, logo abaixo - aventando a possibilidade de estar alterando a essência de uma musicalidade tão original. Porém, em iniciativas extremamente compromissadas com a pesquisa como a do Grupo Paranga, os grupos de folia são valorizados pelo trabalho realizado, atingindo novos públicos e apresentando novos caminhos, ou seja, contribuindo imensamente para a dinâmica do mundo do popular. Permitir e apoiar releituras como essa é ir de encontro às demandas que a sociedade contemporânea apresenta ao próprio mundo do popular.

Apresento a comparação das releituras dessas canções para sustentar o argumento de que a cultura popular se adapta e busca sempre novos caminhos. Quando escutamos uma folia do Divino hoje em dia ${ }^{341}$, é sempre tentadora a perspectiva de valorização pelo viés estrito da constituição do "folclore nacional". Sem falar que a concepção presente ainda é a de um folclore que resiste quase que num caráter épico à modernidade. Graças às reflexões durante a pesquisa, foi ficando muito claro o quanto estes cantos das folias - e a cultura popular na totalidade de suas manifestações - são importantes por revelarem muitas características de um modo de vida específico. Contudo, servem também de referência para os outros setores da sociedade, como outros grupos musicais inseridos no mercado fonográfico, justamente, o caso do exemplo que segue adiante.

Na verdade, a música popular contemporânea que trabalha com o universo do popular insere-se na mesma discussão que apresentamos anteriormente, do crescimento vertiginoso do turismo, acompanhado por uma ânsia de transformação de cultura em formas de entretenimento. É sempre necessária a vigilância para garantir que as iniciativas musicais visam apoiar e fortalecer suas referências populares, e não se aproveitar de uma proposta falsa de apoio, transformando sua fonte em mercadoria. Veremos que tanto o caso do Paranga como do Matuto Moderno são exemplos muito positivos de criação a partir de fontes musicais populares.

\footnotetext{
${ }^{341}$ Como a faixa 1 do Cd que acompanha o disco - vide nota de rodapé 244 para maiores informações sobre a canção da folia do divino de São Luiz do Paraitinga em questão.
} 
Aliás, a banda paulistana A Barca ${ }^{342}$ refez, recentemente, a mesma trilha de Mário de Andrade que resultou em seu livro Turista Aprendiz ${ }^{343}$ décadas atrás, com o propósito de pesquisar e fortalecer a identidade da música popular brasileira. Por trás de novas releituras, estava em pauta a mesma questão da busca da identidade da cultura popular brasileira na atualidade através do campo musical. E, embora muitos continuem classificando criticamente como um projeto que propôs buscar a valorização da "irreal pureza" da musicalidade do folclore brasileiro, essa iniciativa da banda A Barca deu, em minha opinião, um grande exemplo de como inserir esta musicalidade em padrões mais próximos ao do mercado - parece uma defesa paradoxal pois o que esta banda mais prega, talvez, seja justamente uma distância da tônica buscada pelo mercado "pop" -que, ao invés de deturpar, modificar, acabou por valorizar imensamente os próprios grupos inspiradores.

No caso do projeto da Banda A Barca, essa valorização foi feita de maneira muito concreta: dividindo-se os direitos autorais da venda dos produtos do projeto, fazendo shows para as comunidades, oferecendo oficinas entre outras diversas formas de valorização, destacadamente a possibilidade de colocar em discussão esses grupos há tanto tempo marginalizados.

Mas entremos num exemplo mais claro para discutir o tema desta pesquisa sobre a festa do Divino de São Luiz do Paraitinga. A primeira reinterpretação musical de um grupo tradicional de folia que proponho é a do Grupo Paranga, um ícone luizense de "sucesso" dentro da música popular brasileira. Montado em fins dos anos 70 com o principal objetivo de pesquisar o "folclore luizense e levá-lo aos quatro cantos do país, interagindo com as mais diversas formas da riqueza da cultura nacional ${ }^{\circledR 344}$, o Grupo Paranga conseguiu uma projeção considerável no cenário musical brasileiro. Participou, durante os anos 80 , do reconhecido movimento do teatro Lira Paulistana e de programas de destaque da mídia como o Fábrica do Som da TV Cultura e Som Brasil, de Rolando Boldrin, na TV Globo.

\footnotetext{
342 A banda paulistana A Barca surgiu em 1998 com a proposta de "pesquisar e participar da movimentação da cultura brasileira. Com a música como elemento primordial, mas não único, parte da reflexão sobre o fazer artístico e suas responsabilidades estéticas e sociais, realizando um trabalho abrangente de criação de espetáculos, documentação, arte etc" in www.barca.com.br

343 ANDRADE, Mário. Turista aprendiz. $2^{a}$ edição, São Paulo: Livraria duas cidades, 1983.

${ }^{344}$ Entrevista com Galvão Frade, fundador e ex-integrante do Grupo Paranga. Hoje, é o atual secretário da cultura da prefeitura municipal de São Luiz do Paraitinga, março de 2008.
} 
Ainda em atividade, o Grupo Paranga mantém esta perspectiva de divulgação da cultura luizense e de seus principais compositores, com destaque especial a Elpídio dos Santos - pai da maioria dos integrantes e compositor da trilha sonora de quase a totalidade das músicas dos filmes de Amácio Mazzaroppi.

A canção que escolhi para analisarmos faz parte do primeiro disco do grupo chamado Chora Viola Canta Coração e lançado justamente no teatro Lira Paulistana no ano de 1981. Mostra um trabalho muito importante de como realizar uma releitura de uma folia como a gravação apresentada na faixa 1 do Cd que acompanha a dissertação Atento apenas de que a canção do Paranga (1981) é anterior à folia do mestre Dito Geraldo (1984), porém, isso não muda em nada o propósito da comparação de releitura. Afinal, a estrutura da folia de 1984 é muito semelhante à de décadas anteriores ${ }^{345}$. Escutemos, então, duas canções unidas, interpretadas pelo Grupo Paranga ${ }^{346}$ e reproduzidas na segunda faixa do CD de áudio que acompanha esta dissertação: a primeira - chamada Fulia do mestre Luiz de Catuçaba - é a execução reinterpretada de uma folia do Divino pesquisada pelo próprio grupo no início da década de 1980; a segunda - composição Cai Sereno de Elpídio dos Santos e Conde - traz a mesma linguagem musical que imprimem as folias, mas, já proposta como uma música popular de entretenimento.

A) Fulia

Mestre Luiz de Catuçaba

LP "Chora Viola Canta Coração" -Grupo Paranga, 1981.

Aqui chegou na nossa frente

Essa bandeira sagrada

Bate-hora canta-galo

Ai meu senhor

Sereno da madrugada

Ai meu Deus

Tão contente ele chegou

De bem longe ele vem vindo

Venha logo abrir a porta

Ai meu senhor

Que o sereno está caindo

Cantemos reino da glória

Ai meu Deus

\footnotetext{
345 Como os cantos da atualidade também.

346 Para uma maior compreensão sugiro escutar novamente a primeira canção do CD gravável - para perceber o universo de origem da segunda audição. O Cd está no anexo I.
} 
B) Cai sereno (na rama da mandioquinha)

Elpídio dos Santos e Conde

LP "Chora Viola Canta Coração"-Grupo Paranga, 1981.

\begin{abstract}
Cai sereno cai
Na rama da mandioquinha

Eu joguei água de cheiro

No colo da moreninha

Morena, morena

Bonitinha como a flor do manacá

Ajeita morena, ajeita morena

O colo pra mim deitar

Tem pena, tem pena

Vim de longe me cansei de viajar

Ajeita morena, ajeita morena

O colo pra mim deitar
\end{abstract}

Cai sereno cai...

São facilmente identificáveis várias semelhanças com a primeira audição do canto do grupo de folia do Divino. E é fator importante o convívio direto deste grupo com esta realidade. A letra das canções mantém aquele padrão de temas recorrentes, uma estrutura mnemônica, facilmente memorizável, um repertório lingüístico bastante simples, uma canção muito próxima do ritmo da fala mesmo deste grupo social.

Mas se pretendêssemos uma análise mais folclorista, diríamos que esta versão pelo Grupo Paranga de um grupo tão tradicional como o de folia representava uma espécie de "tecido infectado". Um exemplo disso é quanto à técnica musical empregada na execução que lembra a utilização da palheta na viola - um recurso moderno para uma musicalidade tradicional. Configura-se uma musicalidade mais próxima de uma linguagem, de certo modo, "roqueira". Mas de qualquer forma a música não perde sua identidade íntima com uma linha mais tradicional, muito próxima de uma folia do Divino. Mais do que "infectar" é um grande exemplo de reinterpretação e adaptação do popular para novos grupos sociais. 
A própria percussão, a meu ver, lembra imensamente a percussão da canção anterior da folia do Divino. E, quando de maneira brilhante, escutamos os vocais do Paranga nos trechos "Ai meu Deus..." ou "ai ai...", podemos perceber trejeitos típicos do canto popular na forma de cantar. No trecho "eu joguei água de cheiro no colo da moreninha" fica evidente esta não preocupação de se buscar um canto perfeccionista, erudito, de adaptação exata à melodia.

Mesmo no final da canção, quando a corta de repente, é claramente uma das soluções inventivas típicas de rua, desses grupos folclóricos, para um final não estabelecido. Com a diferença que normalmente era para ter sobrado um som de um bumbo ou de uma caixa em um final improvisado, algo que não aconteceu nesta canção do Paranga.

Agora, o que considero mais importante neste exemplo, é que a própria iniciativa de um grupo musical diretamente ligado a esta comunidade de gravar uma folia com uma musicalidade diferenciada, inclusive conectada a uma outra canção, buscava atender a um trabalho de pesquisa - cujo discurso era o da preservação de elementos populares - entretanto, revelando conjuntamente um outro objetivo primordial. O Grupo Paranga, ao dar uma roupagem mais "moderna" e visando atingir a um público maior, acabou por valorizar os grupos de folias tradicionais ao mesmo tempo em que constitui uma marca identitária diferenciada em seu trabalho.

Essas canções explicitam uma mensagem da qual não é a melhor saída ficar discutindo se é música folclórica, se é fiel à raiz, se representa mesmo uma folia, e, sim, perceber a importância que esta iniciativa tem de divulgar e, de uma maneira indireta, valorizar imensamente aquele grupo pesquisado. É uma experiência paralela a de quando Caetano Veloso, os irmãos Campos e todos outros nomes participantes da Tropicália mostraram que o pior caminho era "demonizar" os meios de comunicação em desenvolvimento e perder a oportunidade de divulgação e de alcance de novos públicos que eles permitiam se adotados com uma postura crítica. $^{347}$

\footnotetext{
${ }^{347}$ Há variás referências historiográficas sobre este momento da música popular brasileira. Uma obra mais geral e de referência é MARIZ, Vasco. História da Música no Brasil. Rio de Janeiro: Editora Nova Fronteira, 2000.
} 
Escutar esta "Fulia" do "Grupo Paranga" é, sim, um atalho para discutir o espaço da música popular brasileira e o espaço que o folclore possui em sua identificação com signos como de autenticidade, de nacionalidade, mesmo, ou principalmente, pela leitura ser feita por uma forma adaptada a novos padrões culturais.

Por isso escolhi como terceiro exemplo uma música da banda "Matuto Moderno" que acaba colocando, já de saída, como proposta explícita de trabalho, uma adaptação da linguagem caipira à modernidade ${ }^{348}$. Busca pesquisar temas tradicionais e faz uso dos mais modernos arranjos, utilizando-se de recursos eletrônicos e instrumentos como guitarras com distorções, bateria, contra baixo, entre outros. Comparando com a proposta do "Grupo Paranga", o objetivo é bastante semelhante, porém, a atitude é muito mais deslocada de qualquer preocupação de se manter uma ligação mais direta da musicalidade com aquela feita pelos grupos pesquisados.

O exemplo para escutarmos chama-se "Viva Santos Reis", música integrante do disco "Festeiro", e baseada em "versos e melodias tradicionais das companhias de Folias de Reis Verde e Amarelo de Guará, Brodowski e Jurecê recolhidos por Ricardo Vignini e adaptados por Ricardo Vignini e Alex Mathias" ${ }^{\prime 49}$ - membros da banda "matuto Moderno"

\author{
Viva Santos Reis (folia de Reis) \\ Adaptação Ricardo Vignini e Alex Mathias \\ CD "Festeiro"-Grupo matuto Moderno, 2002. ${ }^{350}$
}

De tão longe que viemos

Acabemos de chegar

Nesse dia tão bonito

Todos com muita emoção

\footnotetext{
${ }^{348}$ O trabalho feito pela banda "Matutos Modernos", formada em 1993 por ex-integrantes de uma banda de rock, se classifica em seu site www.matutomoderno.com.br como "a principal banda do chamado movimento pós-caipira - ou o caipira pop -. (...) a banda Matuto Moderno faz um eletrizante Rock'n'roça, ou seja, uma engenhosa mistura de viola caipira com guitarra distorcida, ritmos da catira, cateretê, cururu, congo, toada, recortado, moda de viola e efeitos eletrônicos.".

349 O disco "Festeiro" foi gravado entre 2001 e 2002 no estúdio "Space Blues" e no estúdio "Música Bacana" de São Paulo.

350 A canção está reproduzida na faixa 3 do CD de áudio que acompanha esta dissertação e seria interessante sua audição neste momento para acompanhar o restante do texto. Anexo I.
} 
Chego até arrepiar

Vendo todo esse povão

Nas casas que nóis canta

Tratam a gente como irmão

Nóis canta o dia inteiro

Em louvor a essa bandeira

E nóis canta com amor

E muita satisfação

Faço a minha despedida

O povo dessa cidade

Vou guardar no coração

Peço muita saúde

E muita felicidade

Até amanhã para vocês

Até o ano que vem

Por não conhecer os grupos de folia pelos quais essa canção baseou-se, não poderia afirmar com certeza que embora preserve uma linguagem bastante simples, a reafirmação de símbolos como a bandeira e temas como o sacrifício em louvor ao sagrado, já parece uma letra de um grupo mais adaptado a apresentações exteriores ao ciclo religioso de uma folia de Reis mais tradicional. No final, por exemplo, se despedem como estivessem encerrando uma apresentação em uma cidade que não seria a de origem já que se guardaria o povo "dessa cidade” no coração.

Mas não é essa mesma a questão que considero mais importante, uma vez que ainda se trata de um tema tradicionalíssimo. A roupagem que a banda imprime, já deixa claro logo no início da canção, tratar-se de uma nova linguagem. A viola caipira é utilizada com "sampler" e o ponteado não é tradicional, pois são utilizados recursos eletrônicos no arranjo, na percussão, ou seja, é uma adaptação clara de um tema tradicional a uma linguagem moderna, pop, da música popular urbana contemporânea.

A caixa da bateria na introdução da canção tem uma batida clara de rock agora não uso aspas como na palheta da viola do "Grupo Paranga" - sempre no tempo três, compasso sim, compasso não. É uma coisa diluída, que não apaga a preocupação da valorização do tema tradicional, mas que está ali justamente para 
mostrar como uma das marcas mais fundamentais do ritmo que consideramos pop poderia ter a intenção de valorizar a musicalidade popular.

A maneira de se cantar mantém uma forma bastante tradicional, mas em alguns momentos pode até aludir um pouco ao jeito explorado pelos cantores do que podemos chamar de "sertanejo moderno", como as duplas Zezé de Camargo e Luciano, Chitãzinho e Xororó, inegavelmente transformadas em grandes produtos comerciais. Tem também, não como objetivo, mas que acaba sendo expresso, uma preocupação de uma musicalidade mais limpa, uma voz mais clara que as outras duas audições anteriores.

A viola e o violão de sete cordas são bastante perfeccionistas na introdução e mostram uma vivência maior de estúdio. Não viso entrar em classificação de qualidade de arranjo, só de evidenciar que não é apenas uma transposição do "clima da apresentação de uma folia" que se busca nesta canção.

Durante a música podemos identificar também frases de violão de sete cordas que lembram muito a musicalidade do choro, ou seja, uma outra forma de influência musical. Acho interessante para a discussão, afinal, a influência do choro no arranjo de uma canção de folia de reis poderia ser utilizado para argumentar que se estaria modificando, com este arranjo, uma musicalidade ainda mais tradicional que o conhecido gênero musical brasileiro do choro. Algo que soa como incoerente, porém, a questão justamente assenta-se nesta não limitação de uma experiência como essa, visando extrair dela uma autenticidade que acaba limitando-a.

Na canção do "Grupo Paranga", os elementos de percussão imprimem a tônica da canção, como é na apresentação de um grupo de folia. Os graves nas duas canções anteriores, estão todos baseados nos instrumentos de percussão. $\mathrm{O}$ arranjo da banda "Matuto Moderno" está, mesmo que discretamente, assentado no contra baixo e na bateria - um recurso muito mais próximo dos arranjos das canções que costumamos escutar nos principais veículos de comunicação.

Inconscientemente ou não, a maneira como esta última canção se apresenta é algo muito mais próximo daquela forma que o "mercado" incentiva como modelo de composição. Mesmo sendo claro que "Matuto Moderno" representa um ícone de valorização da música popular, completamente diferente de muitas iniciativas 
musicais "homogeneizantes" que dominam o mercado atualmente, acaba se posicionando, nesta comparação entre estas três canções, muito mais próximo de uma possibilidade de divulgação e propagação nos principais meios de comunicação por entrar mais diretamente nesse processo constante de negociação entre mercado e musicalidade popular.

Porém, mais importante que discutir então qual forma é mais autêntica, qual representa melhor a musicalidade brasileira, é enxergar a imensidade de relações que podemos estabelecer a partir de uma canção como nesses exemplos, relações que transcendem o universo musical, com impactos sociais e políticos.

Assim, já nem soa mais como surpresa uma declaração como a do mestre da folia do Divino, José de Arimatéia, quando escutei - com ele - as canções analisadas do "Grupo Paranga" e do "Matuto Moderno" e que esperaria uma opinião que rechaçaria aquelas iniciativas:

“ A música do Paranga é muito próxima do que nós fazemos, e desta outra banda que não conheço é muito distante, mas, não deixa de citar uma folia e de valorizar a gente, né ?! (...) O nosso papel é outro. É religioso, não é do campo musical, mas, se quer comparar as três canções, para mim é tudo a mesma coisa, é tudo música de nossa cultura... do Brasil, né?! (...)".351

É apenas um exemplo - da música popular - comprobatório da amplitude de questões que surgem a partir da Festa do Divino de uma cidade como São Luiz do Paraitinga. Inclusive, espero que a inserção dessas músicas tenha permitido refletir um pouco sobre as conexões entre o popular tradicional - destaque ao papel religioso - e o popular de mercado, cada vez mais presentes na sociedade brasileira.

\section{2 - O carnaval das marchinhas de São Luiz do Paraitinga}

O exemplo anterior da música popular faz com que nos afastemos daquela visão mais cética sobre a possibilidade das manifestações populares, marcadas pela oralidade, não resistirem às transformações tecnológicas. Elas podem, sim, sofrer

\footnotetext{
${ }^{351}$ Entrevista com José de Arimatéia - mestre da folia do Divino de São Luiz do Paraitinga - realizada no dia 24 de junho de 2006.
} 
transformações, mas, na maioria das vezes, encontram novas formas de representação. É importante relativizar e lembrar, entretanto, - como fez o prof ${ }^{\mathrm{o}}$. dro Nicolau Sevcenko no exame de qualificação desta dissertação ${ }^{352}$ - que nem todas as manifestações têm continuidade e se adaptam às novas situações da sociedade. Faz parte da História a admissão da morte, do fim. E isso tem acontecido com muitos grupos na festa do Divino, como o jongo, que não se apresentava mais nas festas desde $2005 .^{353}$

A mensagem que gostaria de deixar marcada é que situações como a extinção do grupo do jongo, ou mesmo, de grupos que ainda persistem mas que perderam muito de sua representatividade, não significam que podemos dizer que a cultura popular de São Luiz do Paraitinga está em forte processo de decadência. A situação atual da sociedade luizense tem demonstrado muitas transformações - como a questão do turismo já levantada - entretanto, ainda há uma forte identidade da população como um todo com a linguagem do popular. Mesmo com o desaparecimento de muitos grupos, há novas formas de representação que trazem muitos dos signos partilhados por aqueles que não se mantiveram. Um grupo de capoeira é totalmente diferente em seu propósito de um grupo de congada ou moçambique, porém, tem constituído o seu espaço dentro das festas do Divino mais recentes.

Embora o tempo não tenha permitido uma análise mais a fundo das novas manifestações populares da cidade de São Luiz do Paraitinga, além daquelas relacionadas ao Divino, gostaria de ao menos citar a importância que tem adquirido na cidade o seu típico carnaval. Hoje, este evento, que passou a ser realizado nos moldes atuais somente a partir de 1981, já se transformou na principal manifestação cultural da cidade em divulgação, presença de público e reconhecimento exterior, ultrapassando a própria festa do Divino.

\footnotetext{
${ }^{352}$ Realizado em setembro de 2007 no Departamento de História da FFLCH/USP.

${ }^{353}$ Ressalva - como apontado no capítulo anterior - que no ano de 2008 houve uma tentativa de revitalização do jongo luizense, graças a uma iniciativa pessoal do prof. ${ }^{\circ}$ T. Alberto Ikeda
} 
Foto 07 - Centro histórico de São Luiz do Paraitinga lotado no Carnaval 2008

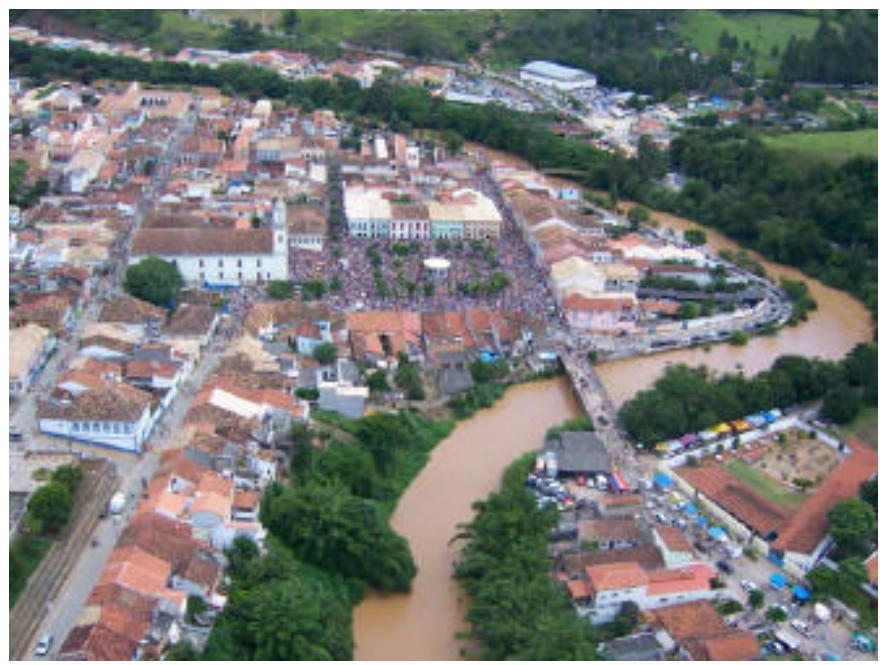

Fonte www.saoluizdoparaitinga.sp.gov.br

Exemplo disso é o público imenso recebido na cidade de apenas dez mil habitantes ${ }^{354}$, como observamos na imagem a praça central da cidade fica totalmente ocupada, e a divulgação nos principais canais midiáticos do país, e até do exterior, como a recente reportagem de capa do caderno "Travel", do jornal norte-americano The New York Times, intitulada "Carnaval on a Smaller Stage"355 que valoriza justamente o caráter tradicional e particular da folia através de um breve histórico da mesma:

“ This small town in São Paulo state's interior is about 115 miles from the capital and only 30 miles down the road from the popular beach resort of Ubatuba. Carnaval went on a 60-year hiatus here starting in the 1920s, when an Italian priest did away with it on moral grounds. But things started up again in 1981, and now the town is know for having one of the best old-fashioned street carnivals around.

An official decree actually prohibits more modern rhythms like samba and axé; the official music genre of the blocos here is the traditional

\footnotetext{
354 "São Luiz do Paraitinga recebeu 150 mil pessoas no Carnaval de 2008”. Caderno 2, página 5, jornal “O Estado de São Paulo", 08 de fevereiro de 2008. É importante questionar este número de 150 mil pessoas, cifra absurda pela estrutura da cidade de São Luiz do Paraitinga. As estatísticas da policial militar e da prefeitura municipal sobre o Carnaval 2008 falam em 20 a 30 mil pessoas diárias nos dias de Carnaval na cidade. Uma cifra ainda assim muito grande lembrando que é de aproximadamente seis mil pessoas o número de habitantes de toda a zona urbana da cidade e os eventos do Carnaval estão todos centralizados no centro histórico. O que a reportagem do jornal "O Estado de São Paulo" deve ter feito é somado o número de pessoas dos cinco dias de carnaval, chegando ao número de 150 mil pessoas, entretanto, acaba-se contabilizando a mesma pessoa que passou todos os dias da festa na cidade mais de uma vez.

${ }^{355}$ KUGEL, SETH. "Carnaval on a Smaller Stage”. The New York Times, January 27, 2008. Disponível no endereço eletrônico http://travel.nytimes.com/2008/01/27//travel/27journeys.html
} 
marchinha, or carnival march, which dates back to the 1920s and was a staple of Carnaval through the mid-20 ${ }^{\text {th }}$ century. Over 1500 local marchinhas have been composed locally since Carnaval started again. (...) The costumes worn by the blocos are similar the carnivals across the country, with bloco-specific themes, which this year include everything from babies to bus drivers. (...) ${ }^{, 356}$

A reportagem do "The New York Times", curiosamente, faz referência ao Monsenhor Ignácio Gióia, que proibiu, além do Carnaval local, as manifestações profanas das festas do Divino, como apresentado no capítulo III desta dissertação. Aparentemente, não há possibilidade alguma de comparação em como são concebidos um evento tão religioso como a festa do Divino e uma festividade carnavalesca. Contudo, o carnaval também apresenta variados exemplos de acontecimentos que ocorrem de maneira semelhante durante as festas do Divino: são representativos de um ambiente que foge ao cotidiano, marcado pela rua, pelo improviso, pela oralidade e pela possibilidade de inversões sociais.

“ No Brasil, sabemos que o carnaval é uma festa especial e também uma trapalhada, uma confusão, uma bagunça. Um momento em que as regras, rotinas e procedimentos são modificados, reinando a livre expressão dos sentimentos e das emoções, quando todos se podem manifestar individualmente". 357

Mesmo percebendo um Carnaval local que cada vez mais tem se massificado, sendo freqüentado por pessoas sem ligação alguma com a cultura popular e com a cidade, seus eventos são pensados e cresceram sendo valorizados pela sua identidade ímpar. A cidade criou um carnaval extremamente diferenciado: o repertório musical é exclusivo de marchinhas carnavalescas, entretanto, não no mesmo ambiente do começo do século XX como fala a reportagem do jornal norte-americano e, sim, reinventada e fortemente influenciada por toda a musicalidade dos grupos folclóricos, das bandas musicais e da tradicional fanfarra local. Novas tendências e ritmos da música brasileira já fazem parte das marchinhas luizenses há algum tempo também, em um processo de miscigenação cultural muito interessante.

\footnotetext{
${ }^{356}$ Idem nota anterior.

${ }^{357}$ DaMATTA, Roberto. Carnavais, malandros e heróis: para uma sociologia do dilema brasileiro. Rio de Janeiro: Rocco, 1997. página 157-158.
} 
Como já dito, os blocos carnavalescos não reverenciam personagens tradicionais do Carnaval como o pierrô e colombina e, sim, ícones da cultura local como o Juca Teles - oficial de justiça que registrou a maioria da documentação das festas da cidade em meados do século XX-e personagens das lendas locais. Podemos perceber na imagem abaixo estes personagens e a maneira artesanal de confecção dos bonecos. As técnicas de construção dos bonecos são as mesmas utilizadas nos bonecões João Paulino e Maria Angu presentes nas festas do Divino.

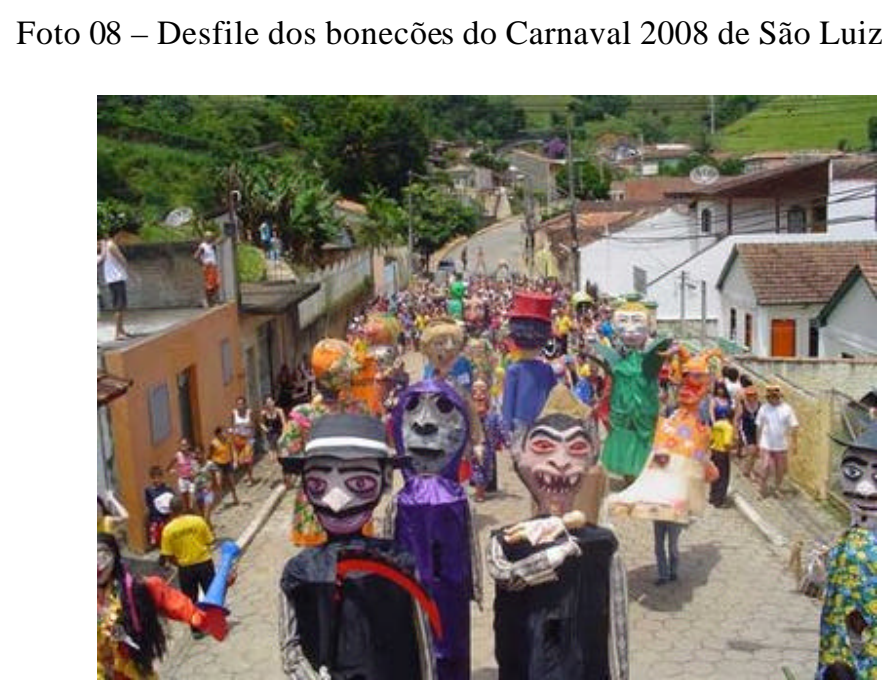

Fonte: foto de Cássio Ribeiro

As fantasias e alegorias dos foliões são também muito inventivas e a cultura luizense tem praticamente criado uma "nova moda". São confeccionadas fantasias sobretudo pelos luizenses ou visitantes que já conhecem as características do carnaval local - muito coloridas e baseadas no tecido florido da "chita": um tecido muito barato que vem se transformando em uma espécie de moda elegante nos grandes centros, na confecção de bolsas, cortinas, toalhas entre outros.

“ Nos primeiros anos da década de 1980, quando começamos a colocar os primeiros blocos na rua, não tínhamos recurso algum para montar as fantasias. Como a 'chita' era um pano barato e colorido, tive a idéia de utilizálo para fazer as fantasias dos meus filhos e de todos aqueles que iam sair no bloco "Zona do Agrião", nas noites do Carnaval. Passávamos horas e horas bordando alguns detalhes daquele pano tão feiozinho, mas, muito alegre ao mesmo tempo..." 358

\footnotetext{
${ }^{358}$ Entrevista com Dona Cinira dos Santos em outubro de 2007.
} 
Percebamos o quanto esta identidade muito forte da cultura local presente nos luizenses durante toda a sua história e, que tanto reafirmamos ao analisar os momentos da festa do Divino, acaba imperando nesse evento contemporâneo. Legitimar-se dentro de uma festa tão tradicional no país, como o carnaval, através de uma trilha sonora própria, personagens, alegorias e figurinos também próprios, demonstra claramente a capacidade de reinvenção e adaptação da cultura popular brasileira nos espaços onde ela está realmente constituída e representada.

Obviamente que não estou assumindo uma posição que simplesmente aceita como natural o desaparecimento e decadência de eventos seculares como os presentes nas festas do Divino pela simples suplantação de outros com alguns signos semelhantes como os presentes no carnaval local. Aliás, cada vez mais esse carnaval tem atendido a interesses econômicos e da valorização do entretenimento, apresentando a cultura popular como uma espécie de espetáculo para o crescente público turístico. ${ }^{359}$

No entanto, essa festividade carnavalesca, também é instrumento de valorização e resistência e da tentativa de manutenção da expressão de um modo de vida totalmente diferenciado na atualidade. Graças à constituição de uma identidade e uma memória coletiva efetivamente consistente no decorrer da história da sociedade luizense, torna-se possível continuar encontrando elementos, como a oralidade, ainda reverberados em diversas manifestações atuais.

O Carnaval de São Luiz do Paraitinga tem crescido exponencialmente sobre uma fórmula que prima pela manutenção de elementos típicos do mundo do popular, como discutimos nos principais momentos da história da festa do Divino. A própria opção da criação de um gênero próprio - as marchinhas são um estilo presente em muitos lugares, mas que em São Luiz do Paraitinga possuem características peculiares - utilizando-se das influências musicais e temáticas regionais mostra a força da cultura local. Os festivais de marchinhas carnavalescas são realizados todos

\footnotetext{
${ }^{359}$ É muito interessante a abordagem crítica do geógrafo local, Carlos Murilo Prado Santos, sobre esta "espetacularização" da cultura e do patrimônio de São Luiz do Paraitinga em recente artigo publicado na Revista Eletrônica de Turismo Cultural da ECA/USP www.eca.usp.br/turismocultural/carlos.pdf denominado "Desorganizando e organizando o território: o turismo e o desenvolvimento local em São Luiz do Paraitinga". Artigo síntese de sua dissertação já citada anteriormente : $O$ reencantamento das cidades: tempo e espaço na memória do patrimônio cultural de São Luiz do Paraitinga/SP. Dissertação de mestrado. Universidade Estadual de Campinas, Instituto de Geociências, 2006;
} 
os anos - semanas antes do carnaval - e envolvem uma parcela importante da comunidade durante os ensaios e apresentação das canções. A cidade já conta com mais de mil e quinhentas músicas compostas em pouco mais de vinte anos de carnaval nestes moldes. ${ }^{360}$

Como citado pela reportagem do "New York Times", há pouco, a cidade passou quase todo o século XX sem Carnaval. Logo que o Monsenhor Ignácio Gióia chegou à cidade - em 1916 -, ele proibiu todas manifestações consideradas, por ele, profanas. Surgiu um mito na cidade que o carnaval causava "rabo e chifre" e em meados do século XX cessam, inclusive, os bailes de salão.

Não foi por acaso então que o tema da retomada do Carnaval da cidade, que aconteceu no ano de 1981, logo após uma reportagem do tradicional "Jornal Nacional" da Rede Globo de Televisão, que tratava da cidade com ironia por não realizar a festa mais tradicional do país, por medo de "pragas religiosas", chamou-se o Carnaval do "Rabo e Chifre":

"Minha primeira composição, em 1981, foi "Rabo e Chifre". Passou uma reportagem grande no 'Jornal Nacional' que praticamente chamou a gente de bobo por não realizar o carnaval com medo de pragas. Esta primeira canção foi praticamente um samba. Não era bem a marcha ainda, mas estávamos justamente construindo nosso novo estilo. Aliás, depois começamos a fazer marcha e nunca mais fizemos samba para o Carnaval. Considero muito importante para o início do carnaval luizense o conjunto "Sambolero", uma típica banda de baile dos anos 80. Tocávamos em outras cidades: Lorena, Ubatuba, São José dos Campos entre outras e estava mais do que na hora de tocar em nossa cidade. Aproveitando da ocasião e ajudados por vários músicos locais - como a turma da família do Grupo Paranga -, convidamos o presidente do Clube na época, o Zezé do Mikilin, para que ele fizesse o primeiro Carnaval da cidade... que ainda foi dentro do Clube. Ele ficou com medo de dar prejuízo e fizemos assim mesmo! Acabou sendo um sucesso e já, em 1982, quando definitivamente apareceram as primeiras marchinhas de Carnaval, o carnaval começou a crescer e ganhou as ruas, surgiram os primeiros blocos - Zona do Agrião, Ovelhas Negras, Petróleo, Melindrosas, Rua Nova - e depois disso, só cresceu..."361

\footnotetext{
${ }^{360}$ Segundo projeção de Galvão Frade - um dos idealizadores do Carnaval local, ex-membro do Grupo Paranga e atual diretor de cultura da prefeitura municipal de São Luiz do Paraitinga.

${ }^{361}$ Entrevista com o músico e compositor José Roberto - conhecido pelo apelido "Quadô" - , de 24 de março de 2005. Retirada do projeto de pesquisa "Compositores Luizenses" - de minha autoria em conjunto com o músico Paulo Baroni - que tem recolhido e transcrito depoimentos dos compositores locais visando à construção de um histórico da festa local. O músico Quadô, infelizmente, faleceu poucos meses depois de proferir este depoimento.
} 
Realmente, é impressionante como foi rápido o crescimento desse evento que hoje recebe milhares de turistas originários das mais dversas cidades do país. E, como dito há pouco, mesmo tratando-se em seus princípios ideológicos de um momento totalmente diferente de uma festa do Divino Espírito Santo, o carnaval das marchinhas de São Luiz do Paraitinga contribui imensamente para a afirmação de muitos signos comuns e fundamentais à manutenção do perfil cultural tão elogiado de sua comunidade. São exemplos disto, o carnaval tratar-se de um momento da excepcionalidade do cotidiano - em um tempo diferenciado e, por sinal, como a festa do Divino, cíclico -, da criação de simbologias próprias e que reúne a comunidade em seu entorno, além, da própria confirmação pela sua população, - é bem verdade atraída muito pelo sucesso midiático da festa - da importância da manutenção da cultura local como recurso de reconhecimento no mundo moderno.

Como bem diz Néstor Garcia Canclini: “ As práticas culturais são, mais que ações, atuações." 362

\section{3 - O "Raloim Caipira" e as últimas considerações}

Para finalizar, é necessário registrar o surgimento da SOSACI - Sociedade dos Obseravdores de Saci -, uma associação civil, sem fins lucrativos, criada com o intuito de valorizar, através da figura mítica do saci-pererê, a cultura nacional em detrimento da invasão estrangeira neste setor. Gostaria de apresentar rapidamente a SOSACI neste trabalho por acreditar estar representado em sua criação a confirmação da cidade luizense como um ícone da defesa da cultura brasileira de uma forma mais ampla na atualidade. Status alcançado graças a todo o histórico da proeminência do popular no dia-a-dia da comunidade.

A SOSACI surgiu por iniciativa de um grupo de intelectuais que, inicialmente, poucas ligações possuíam com São Luiz do Paraitinga. Iniciou-se a partir de várias reuniões feitas por um grupo heterogêneo, formado por vários jornalistas, músicos e nomes representativos no campo cultural brasileiro - como

\footnotetext{
${ }^{362}$ CANCLINI, Néstor Garcia. Culturas Híbridas: estratégias para entrar e sair da modernidade: São Paulo, Editora da Universidade de São Paulo, 2003.
} 
Ziraldo, por exemplo - em sua maioria, da cidade de São Paulo, preocupados com o espaço da cultura popular na sociedade contemporânea. Um destes nomes, o jornalista Jô Amado, que residia em São Luiz do Paraitinga na época, pensou em utilizar esta cidade como sede da organização em criação, justamente pela representatividade positiva de estar situando-a em um local símbolo da cultura popular.

No ano de 2003, foram realizadas reuniões em São Luiz do Paraitinga, com a participação de alguns membros da comunidade luizense, e, constituída a associação oficialmente fundada no dia 07 de setembro ${ }^{363}$. As festas do "saci-pererê" na cidade têm contado com a apresentação de grupos musicais, contadores de história e apresentações teatrais de várias localidades do estado de São Paulo, além dos artistas luizenses e de projetos desenvolvidos com os alunos das escolas da cidade. Acabou constituindo um fundamental intercâmbio cultural dos luizenses com os artistas de outras localidades.

Aliás, foi escolhido o dia 31 de outubro como data ideal para se celebrar o "Raloim Caipira". Uma clara provocação ao tradicional Halloween norte-americano, substituindo-se a tradicional personagem da bruxa por entes do folclore nacional como o simbólico saci-pererê mas também o boitatá e curupira entre outros. $\mathrm{O}$ cardápio culinário oficial do evento sugere anualmente também aos visitantes o prato de abóbora com carne seca dentro dessa "missão" de enfrentamento proposto pelos membros da associação. O texto publicado pela própria SOSACI em 31 de outubro de 2003 é representativo desta proposta:

\section{"Manifesto Antropófago revisitado}

Qualquer semelhança com o Manifesto Antropófago de Oswald de Andrade, do ano de 1928, não se trata de mera coincidência!

Só o saci nos une. Sacialmente. Etnicamente. Culturalmente. No ano 449 da deglutição do Bispo Sardinha em Piratininga, e 75 anos após o lançamento do Manifesto Antropófago de Oswald de Andrade, os saciólogos desta terra vão, aos pulos, convergindo em torno da única lei justa do mundo globalizado. $\mathrm{O}$ saci resgata nossa identidade, nossas raízes, o xis da questão tupi. Contra todas as catequeses do Império só nos interessa o que não é deles. A lei do saci. Estamos fatigados de todos os colonialismos travestidos de drama roliudiano.

\footnotetext{
363 Registrada oficialmente no Cartório de Imóveis e Anexos de São Luís do Paraitinga em 10 de fevereiro de 2004.
} 
O cinema americano devorando corações e mentes. Demente. No país onde dá status ter casa em Maiami e comprar em sales com $20 \%$ off. Estacionar no valet parking e pedir comida delivery. Por isso fazemos eco ao brado oswaldiano, contra todos os importadores da consciência enlatada. Oswald ainda grita, resquícios do nheengatú ecoando ao longe. Nunca admitimos o nascimento de Jeca Tatu entre nós. Só que o Jeca de Lobato resiste. Ele resiste ao Pato Donald, aos Poquemons, ao Raloim, às bruxas do Bush.

O instinto do Saci. Só Saci. Um Saci contra as histórias do homem que começam no Cabo Canaveral. A fixação do progresso por meio de catálogos e aparelhos de televisão. E os transfusores de sangue. Das veias abertas da América Latina. Antes dos norte-americanos ocuparem o Brasil, o saci já tinha descoberto a felicidade. Definida pela sacizidade de um antropófago, o próprio Saci. A transfiguração da Abóbora em carne seca. Antropofagia. Absorção do inimigo abóbora.

A nossa independência já foi proclamada no 7 de Setembro, em São Luís do Paraitinga. Expulsamos o imperialismo travestido de globalização hegemônica. Contra a realidade social, vestida e opressora, cadastrada em Washington e Londres, a realidade sem complexos e sem penitenciárias do saciarcado de Pindorama.

São Luis de Paraitinga, 31 de outubro de 2003, ano da deglutição final da abóbora"364

Fiz questão de transcrever todo este manifesto pois acabo considerando-o uma síntese do verdadeiro desafio da cultura popular luizense na contemporaneidade feito por intelectuais de fora da cidade. Reconhecendo toda a importância da cultura popular luizense este manifesto acaba colocando sua cultura a serviço de uma dada identidade nacional. Se discutimos no decorrer de momentos da história local a decadência de algumas manifestações, a transformação ou mesmo a manutenção de outras, é só a nova realidade de uma cidade turística que pôde permitir o surgimento de uma associação como essa e, definitivamente, marcar a importância cultural construída e solidificada pelo município luizense em toda sua história.

É bem verdade que o manifesto da SOSACI representa uma visão de mundo completamente diferente das camadas populares até mesmo pela erudição apresentada na argumentação. Defende muito claramente ainda, um forte caráter de rejeição pura e simples ao estrangeiro - como vimos algo que não corresponde às atitudes freqüentes do mundo do popular - e, elege como símbolo de defesa um mito que não é local, aliás, talvez o mais brasileiro dos mitos quando pensamos em unidade cultural.

\footnotetext{
${ }^{364}$ Texto distribuído aos participantes do evento de 2003 e disponível no site da www.sosaci.org.br
} 
“ Como ele era um ser sobrenatural que expressava a divisão dos brasileiros nada melhor do que forçá-lo a uni-los, opondo aos "estrangeiros". E assim o Saci começou a ficar famoso. Domesticado, o Saci-menino ingressa definitivamente na era da indústria cultural e da publicidade. Com o desenvolvimento do rádio e o advento da televisão nosso personagem alcança projeção nacional. Despojado de seus traços mais sarcásticos, agressivos e contestadores, restaram-lhe as feições miúdas e o ar brincalhão..." 365

Surge então uma última questão: será que a cidade luizense não estaria correndo o risco de "infectar" sua cultura tão forte e com sua identidade bem marcada sucumbindo às tendências que culminariam em grandes espetáculos e entretenimentos como principal interesse?

Se pensarmos que uma festa tão tradicional como a do Divino tem perdido seu espaço de destaque rapidamente para eventos como o Carnaval - altamente diferenciado em sua concepção como vimos, entretanto, cada vez mais massificado - podemos concluir que sim. Se analisarmos que a SOSACI possa estar assumindo um papel de defesa da cultura local, contudo, suplantando o espaço de criação espontânea dos luizenses a partir de um discurso intelectualizado e generalizado, a situação talvez possa, sim, ser considerada preocupante. Isso, sem falar nas situações já levantadas no decorrer do trabalho da ocupação do espaço do popular pelo poder público, dos interesses vorazes do comércio e do turismo...

“ Diversos autores já observaram que, na sociedade brasileira, até mesmo as criações culturais de grupos subalternos terminam sendo apropriadas, redefinidas e exploradas pelas camadas dominantes. Esse processo sutil consiste em "limpar", "domesticar" tais criações, colocá-las no domínio da 'ordem', transformando-as, muitas vezes, em símbolos nacionais. Os exemplos mais conhecidos referem-se ao samba, ao candomblé, à feijoada e aos temas da malandragem". 366

Infelizmente, é necessário assumir a dificuldade da dura realidade do espaço de representatividade da cultura popular brasileira na atualidade. Chegar ao final desta pesquisa e propor um futuro para a festa do Divino Espírito Santo de São Luiz

\footnotetext{
${ }^{365}$ QUEIRÓZ, Renato da Silva. "Migração e metamorfose de um mito brasileiro: o saci, trickster da cultura caipira" in Revista do Instituto de Estudos Brasileiros n³8. São Paulo: Instituto dos Estudos Brasileiros da Universidade de São Paulo, 1995. página 147.

${ }^{366}$ QUEIRÓZ, Renato da Silva. op cit, página 147. Quando cita diversos autores em seu texto Renato Queiróz indica para BORGES PEREIRA, João Baptista. Negro e cultura negra no Brasil atual. Revista de Antropologia. São Paulo, vol 26, 1983; FRY, Peter. Para inglês ver: identidade e política na cultura brasileira. Rio de Janeiro: Zahar, 1982; e OLIVEN, Ruben George. A elaboração dos símbolos nacionais na cultura brasileira. Revista de Antopologia. São Paulo, v26, 1983.
} 
do Paraitinga, ou mesmo a capacidade de sua comunidade de criar novos símbolos e novas representações, não passaria de um erro grave e impreciso. Embora a atual situação do mundo moderno seja mais um dos tantos desafios que a cultura popular sempre enfrentou, não há como negar o "perigo" de que um corpo social consolidado, pautado nos valores de coletividade, identidade de grupo e religiosidade tradicional, se coloque cada vez mais a serviço de funções econômicas e políticas públicas como ressaltado nas discussões anteriores.

Fica claro, apesar de tudo, que todo esse interesse crescente acerca das manifestações culturais da comunidade luizense, revela a "outra face da moeda", justamente a capacidade de resistência, de reinvenção e de modificação da realidade pela cultura popular. Materializa a importância social destas pessoas, costumeiramente tão alijadas das principais representações políticas e sociais. Dessa maneira, qual o motivo então para não crer também na possibilidade da proeminência de muitas de suas manifestações na modernidade, mesmo frente a interesses diversos aos seus?! Ou buscar identificar a importância de transformação de sua presença nesta nova realidade que praticamente não lhes cede espaço? Algo, infelizmente, ainda muito pouco privilegiado pelos discursos históricos.

“ No entanto, não defendi aqui - e, na verdade, não acredito - que a história cultural seja a melhor forma de história. É simplesmente uma parte necessária do empreendimento histórico coletivo. Como suas vizinhas história econômica, política, intelectual, social e assim por diante - , essa abordagem ao passado dá uma contribuição indispensável à nossa visão da história como um todo, " história total', como dizem os franceses.".367

Observar, tomar contato e analisar momentos da festa do Divino e da cultura luizense permitiu vislumbrar versões diferentes de "nossa História". Partindo sempre de baixo para cima, foi possível, justamente, identificar e, em algumas vezes, "implodir" estruturas de autoritarismo e dominação que, costumeiramente, posicionamos como uma espécie de "inimigo invencível”.

${ }^{367}$ BURKE, Peter. O que é história cultural? Rio de Janeiro: Jorge Zahar Editora, 2005. página 163. 


\section{$\underline{\text { Bibliografia }}$}

\section{Documentos consultados}

- Arquivo do Estado de São Paulo. Caixa 25 9033. S Manuscritos São Luiz do Paraitinga (avulsos XVII - XVIII- XIX- XX) população, religião, serviços públicos, terras;

- Arquivo do Estado de São Paulo. Caixa 1 - 9009. S. Manuscritos (1887- 1927?) São Luiz do Paraitinga - Caderno número 31 - de Major Pinto, ou Juca teles do Sertão, oficial de Justiça;

- Arquivo do Estado de São Paulo. Maços de População, cx 33.. Lista Nominativa anual de habitantes da vila de São Luiz do Paraitinga para o ano de 1801;

- Arquivo do Estado de São Paulo. Ofícios da Câmara de Lorena, Guaratinguetá, etc, cx. 06, ord. 232, docs 6-1-18, 6-1-22, 6-1-24 (anos 1725-1726); DI, vol. L., pág. 157, 160, $168,171,245,264$ e 267 ;

- Arquivo do Estado de São Paulo, Ofícios das Câmaras 1721-1822, caixa número 7, São Luiz do Paraitinga, ordenação 233, pasta 3;

- Arquivo do Estado de São Paulo, Ofícios das Camaras/ São Luiz do Paraitinga, cx 7, ord. 233, doc 7-3-24;

- Arquivo do Estado de São Paulo, Ofícios das Câmaras/ São Luiz do Paraitinga, 1721/1822 caixa 7 , ord.233, pasta 3, despacho de 02 de maio de 1769;

- Arquivo de São Paulo. Ofícios diversos/ São Luiz do Paraitinga, ex 470. ord. 1265, Pasta Cap-Mor, oficio de 30 de julho de 1827;

- Arquivo do Estado de São Paulo, Ofícios Diversos/ São Luiz do Paraitinga, cx 472, ord. 1267, ofício de 17 de março de 1852;

- Arquivo do Estado de São Paulo, Ofícios Diversos/ São Luiz do Paraitinga, cx 472, ano de 1862, ofício respondido ao pedido de estatísticas trimestrais em 9 de agosto de 1862 ;

- Arquivo de São Paulo. Pasta População/ São Luiz do Paraitinga, cx 158, ord 158, ano 1774;

- Arquivo do Estado de São Paulo População/ São Luiz do Paraitinga, cx 160, ord. 160, Censo de $1830 ; 1^{\circ}$ Cia, fogos $n^{\circ} 1,2$ e 121 ; e $3^{\text {a }}$ Cia. Fogos $n^{\circ} 324,335,336,337,393$, 397, 399, 410, 421 e 423;

- Arquivo do Estado de São Paulo. Pedido no 23/1915 registrado na Câmara Municipal de São Luiz do Paraitinga da folia de Cunha. 13 de maio de 1915, assinado pelo sr. José Benedito de Souza (contra-mestre da folia). Caixa 9037 do Arquivo do Estado de São Paulo;

- Arquivo do Estado de São Paulo. Pasta SESMARIAS, vol II, pág 95 e 99. e pasta vol III;

- Arquivo do Estado de São Paulo. Pasta Sesmarias, vol IV, pág 20 e 47 e vol III, pág 60

- Biblioteca Nacional do Rio de Janeiro. Carta para Mendos de Foyos Pereira, Secretário de Estado, sobre as pedras minerais de D. Rodrigo de Castello- Barnco, vol LVII, pág 173, apud Tricentenário de Parati, DPHAN n 22, MEC;

- Câmara Municipal de São Luiz do Paraitinga.Arquivo folha 141-142 de 16/04/1809 citado por Jaime de Almeida, acessado em São Luiz do Paraitinga e hoje também depositado no Arquivo do Estado de São Paulo, caixa no 59 (Ordenanças e Atas da Câmara Municipal de São Luiz do Paraitinga). 
-Câmara Municipal de São Luiz do Paraitinga. Pasta atas de sessões (1829-1839), sessão de 04/11/1836 também depositado no Arquivo do Estado de São Paulo, caixa $n^{\circ}$ 59 (Ordenanças e Atas da Câmara Municipal de São Luiz do Paraitinga);

- CAMPOS, Benito. Discurso em lomenagem ao "Rei Nobre do Congo, Arcidão", acervo pessoal, São Luiz do Paraitinga, 26 de janeiro de 2008;

- Censos Demográficos Nacionais IBGE: anos de 1991, 2000 e 2006. Fonte www.ibge.gov.br/cidades/default selecionando-se o município de São Luiz do Paraitinga;

- Circular do Departamento de Imprensa e Propaganda do Governo Vargas distribuída às prefeituras municipais in Mattos Ibiapina, Júlio de. O Brasil de ontem e o de hoje. [Rio de Janeiro]: Departamento de imprensa e propaganda, 1942;

- Governo do Estado de São Paulo. Lei Estadual no 11.197. de cinco de julho de 2002 elevando a cidade à categoria de Estância Turística. Diário Oficial do Estado de São Paulo, Imprensa Oficial do Estado de São Paulo, São Paulo, 2002;

- Governo do Estado de São Paulo. Acervo de bens tombados. CONDEPHAAT. São Paulo, 2006;

- Hemeroteca de Taubaté. Livro Tombo da Matriz de Guaratinguetá. caixa 33 (documentos oficiais de Guaratinguetá - 1750-1780), folha número 5;

- IBGE, Resultados da Amostra do Censo Demográfico 2000 - Malha municipal digital do Brasil: situação em 2001. Rio de Janeiro: IBGE, 2004.

- IBGE, Resultados da Amostra do Censo Demográfico 2006

- Museu Oswaldo Cruz de São Luiz do Paraitinga. MOC- CMSLP. XVIII. F. Festas (1840-1903), docs de 13/04/ 1840, 3/01/1872 e 19/03/1872; Caderno de Juca Teles do Sertão, no 30 ;

- Ofício OF. G. 928/81 a sua Senhoria o Dr. Ariovaldo de Castro Almeida,D.D. Agente do I.N.P.S. - Taubaté do Gabinete da Secretaria de Cultura do Estado de São Paulo, 1981.

- Orçamento da Prefeitura Municipal de São Luiz do Paraitinga ano 2001 .Setor de Tributos.

- Orçamento da Prefeitura Municipal da Estância Turística de São Luiz do Paraitinga ano 2006. Setor de Tributos;

- Paróquia São Luiz de Tolosa. Lista dos Festeiros do Divino ( 1943-2007);

- Plano Diretor Participativo da Estância Turística de São Luiz do Paraitinga consultado na sede da prefeitura Municipal da Estância Turística de São Luiz do Paraitinga;

- Prefeitura Municipal de São Luiz do Paraitinga. Atas das discussões da montagem do plano diretor. Janeiro a novembro de 2006.

- Prefeitura Municipal de São Luiz do Paraitinga. Atas das reuniões do Conselho Municipal de Turismo. 2006-2007;

- Rádio Paraitinga FM 105,9 gravação do programa "Nas ondas da Paraitinga" no mês de novembro do ano de 2006 com o depoimento de Carlos Roberto Santos;

- São Luis do Paraitinga (usos e costumes) - separata da Revista o Arquivo, vol. CXXI. Departame nto de Cultura, São Paulo, 1949;

- Texto de abertura da I Semana da Canção Brasileira (distribuída em folders) do Governo do Estado de São Paulo, novembro de 2007; 


\section{$\underline{\text { Livros da Paróquia local }}$}

- Inventário dos bens existentes anos de 1825, 1826, 1837, 1839, 1895, 1910-1923, 1935, 1998-2006.

- Balancete das festas do Divino (1956, 1959, 1975, 1986, 1988-1996, 1998, 20002008).

\section{Programas de Festas do Divino}

- Todos os programas a partir da festa do Divino desde 1975 ininterruptos. Alguns poucos anteriores como o de Programa da Festa do Divino Espírito Santo da Parochia de São Luiz do Parahytinga, 1916, acervo pessoal de Benedita Antunes de Andrade.

\section{Jornais}

- Jornal "O Luizense": no LIV, II, 20/11/1904; no 334, V, 16/02/1908; no 336, VI,

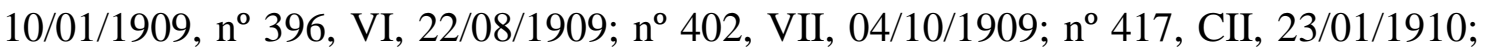
$n^{\circ} 423$, VII, 26/01/1913; no 437, XIII, 13/01/1916; no 444, 02/03/1916, no 472, XIV, 04/10/1916; n n $^{\circ} 554$, XV, 29/08/1918, no 675 08/05/1921; n ${ }^{\circ} 711, X X, 20 / 05 / 1923$. (microfilmes - CAPH/USP)

- Jornal "O Porvir": n03, 19/03/1916; n n 07 20/09/1916; n' 12 03/02/1917; (microfilmes - CAPH/USP)

- Jornal "O Lábaro": no 26, 30/06/1910; no 425, 28/02/1918; n 442, 27/06/1918; no 1250, 20/05/1999; $n^{\circ}$ 1253, 16/08/2003. (Arquivo da Diocese de Taubaté);

- Jornal de Taubaté n²065, XII, pág 1, "Estrada de Ferro de São Sebastião; Jornal de Taubaté no 2078, XII, 16/09/1905, pág.1, Estrada de Ferro; (Hemeroteca de Taubaté)

- Semanário de Taubaté, edição 85, junho de 1948 - (Hemeroteca de Taubaté, setor jornais e semanários, caixa 87- autoria de Mário Aguiar);

- Folha de São Paulo (período agosto 2006 a maio de 2008).

- O Estado de São Paulo (período agosto 2006 a maio de 2008).

- Vale Paraibano (período agosto 2006 a maio de 2008).

\section{Sítios utilizados}

- www.barca.com.br (último acesso em fevereiro de 2008);

- www.eca.usp.br/turismocultural/carlos.pdf; (abril de 2008)

- www.fsp.com.br (acesso constante durante a pesquisa);

- www.estadao.com.br (acesso constante durante a pesquisa);

- www.ibge.gov.br/cidades/default; ( acesso março/ abril 2008);

- www.matutomoderno.com.br; (último acesso fevereiro de 2008);

- www.paraitinga.com.br ( acesso constante durante a pesquisa);

- www.pmparaty.rj.gov.br (último acesso setembro 2007)

-www.saoluisdoparaitinga.sp.gov.br (acesso constante durante a pesquisa);

- www.semanadacancaobrasileira.com.br (setembro/2007) 
- www.sosaci.org.br (março de 2008);

- www.travel.nytimes.com/2008/01/27//travel/27journeys.html (março de 2008)

- www.valeparaibano.com.br (acesso constante durante a pesquisa)

- www.vanguardatv.com.br (acesso constante durante a pesquisa)

- www.vitruvius.com.br/ minhacidade / mc178/ mc178.asp (fevereiro de 2007);

- http://www.portugal-linha.pt/opiniao/jferreira/jf6.html. (maio de 2007);

\section{Cancões utilizadas}

- Canto Folia do Divino de São Luiz do Paraitinga- mestre Dito Geraldo

Registro de 1984 recolhido por Benedito Galvão Frade Junior

Transcrição feita em conjunto com o contramestre, sr. Rafael de Mendonça (2006);

- Fulia

Autor: Mestre Luiz de Catuçaba

LP "Cora Viola Canta Coração" -Grupo Paranga, 1981;

- Cai sereno (na rama da mandioquinha)

Autores: Elpídio dos Santos e Conde

LP “Cora Viola Canta Coração" -Grupo Paranga, 1981;

- Viva Santos Reis (folia de Reis)

Adaptação Ricardo Vignini e Alex Mathias

CD "Festeiro" -Grupo matuto Moderno, 2002.

\section{Entrevistas gravadas (todas em São Luiz do Paraitinga)}

- Afonsina Conceição de Souza, 16 de maio de 2007;

- Antonio Carlos Santos, 19 maio de 2007;

- Antonio da Silva Leme,16 de maio de 2007;

- Benedicta Antunes de Andrade, março de 2006, maio de 2007 e maio de 2008;

- Benedito Candido de Toledo, março de 2008;

- Benedito Galvão Frade, março de 2008;

- Benedito Urbano, junho de 2006;

- Bento Claro Pereira, maio de 2007;

- mestre Brás, 12 de abril de 2007;

- Dona Cinira dos Santos- realizadas nos dias 21, 23 e 26 de setembro de 2006;

- Danilo José de Toledo, agosto de 2006, 10 de dezembro de 2007 e 05 de abril de 2008;

- Eduardo Coelho, março de 2008;

- João Daniel dos Santos, outubro de 2007;

- José de Arimatéia, realizada no dia 24 de junho de 2006;

- José Edimar da Silva Rego, 19 de janeiro de 2008;

- José Roberto Rodrigues ("Quadô"), de 24 de março de 2005;

- Luiz Carlos Luzia Rodrigues, julho de 2007;

- Luiz Carlos da Silva, maio de 2007;

- Maria Antonia Brito, maio de 2006,

- Marco Antonio Rio Branco, janeiro e maio de 2008;

- Monsenhor José Eugênio de Faria, janeiro de 2008;

- Monsenhor Tarcísio de Castro Moura,18 de março de 2007;

- Nelson Alvarenga no dia 18 de dezembro de 2007; 
- Teresinha Clara de Jesus, maio de 2007;

- Zinho Aurélio, junho de 2006;

- Muitas conversas não gravadas com membros da comunidade foram fundamentais para as conclusões deste trabalho (Marcelo Toledo, Carlos Murilo Prado, Judas Tadeu, Galvão Frade, Marco Rio Branco, Thar Ferreira, Pedro Luís (Negão) Santos, Renata Marques, João Gaspar, Aziz Nacib Ab'Saber, Daniel Messias, Joana Egypto, Benito Campos, Netto Campos, César Nunes, Leandro Barbosa, Léo Couto, Rodolfo Santana, Luiz Egypto, Cássia Moradei, tio Expedito, tia Lourdinha, João Felipe, Érica Josiane, Cris Bittencourt e, de maneira toda especial, Luciane Bittencourt e meus pais ) 


\section{$\underline{\text { Livros, teses, dissertacões e artigos }}$}

- ABREU, Martha. O império do Divino: festas religiosas e cultura popular no Rio de Janeiro, 1830-1900. Rio de Janeiro: Nova Fronteira; São Paulo: Fapesp, 1999;

- AB'SÁBER, Aziz Nacib; BERNARDES, Nilo. Vale do Paraíba, Serra da Mantiqueira e Arredores de São Paulo. Guia de Excursão número quatro. XVIII Congresso Internacional de Geografia. Rio de Janeiro: Conselho Nacional de Geografia, 1958 ;

- AGUIAR, Mario. São Luis do Paraitinga (usos e costumes) - separata da Revista o Arquivo, vol. CXXI. Departamento de Cultura, São Paulo, 1949.

- ALMEIDA, Jaime de. Foliões (Tomos I e II). Tese de doutoramento apresentada ao departamento de História da FFLCH-USP. São Paulo, 1987;

- ANDRADE, Mário. Turista aprendiz, $2^{a}$ edição, São Paulo: Livraria duas cidades, 1983;

- ARAUJO, Alceu Maynard. Alguns ritos mágicos: abusões, feitiçaria e medicina popular In Separata da Revista do Arquivo do Estado de São Paulo, 1958;

. Folclore Nacional I: festas, bailados, mitos e lendas. $3^{\text {a }}$ edição, São Paulo: Martins Fontes, 2004;

- ARAUJO, Ana Maria Ramalho Câmara de. A Festa do Divino e suas transformações na comunicação e na cultura. Dissertação de mestrado, PUC/SP, São Paulo, 2003;

- ARTIÈRE, Philippe. Dizer a atualidade: o trabalho de diagnóstico em Michel Foucaul in GROS, Fréderic. (org). Foucault a coragem da verdade. São Paulo: Parábola Editorial, 2004.

- AZEVEDO, Antonio Carlos do Amaral. Dicionário de nomes, termos e conceitos históricos. $3^{\mathrm{a}}$ edição. Rio de Janeiro: Nova Fronteira, 1999;

- AZEVEDO, Paulo de C. Paraitinga no meu tempo. São Paulo: Gráfica Sangirard LTDA, 1986;

- AZZI, Riolando. História da Igreja Católica no Brasil. São Paulo, Edições Paulinas, 1983;

- BAKHTIN, Mikhail. A cultura popular na Idade Média e o Renascimento: o contexto de François Rebelais. São Paulo: Hucitec/ Ed. Universidade de Brasília, 1987;

- BAUMAN, Zygmunt. Modernidade líquida. Rio de Janeiro, Jorge Zahar, 2001.

- BENAMOU, Michel. Postface: In Praise of Marginality in Alcheringa - A first international symposium. Cambridge: Boston, University Press, 1976;

- BEOZZO, José Oscar, e outros. História da Igreja no Brasil. $1^{a}$ época. Tomo II/I. São Paulo, editora Paulinas, Petrópolis, editora Vozes, $4^{\text {a }}$ edição, 1992;

- BESSA, Virginia. Um bocadinho de cada coisa. Trajetória e obra de Pixinguinha. História e música popular no Brasil dos anos 20/30. São Paulo: DH/FFLCH/USP, 2006;

- BLOCH, Marc Leopold Benjamin. Os reis taumaturgos: o caráter sobrenatural do poder régio, França e Inglaterra. São Paulo: Companhia das Letras, 1993;

Europa-América LTDA, 2007; Introdução à História. Portugal: Publicações

- BOSI, Ecléa. Memória e sociedade: Lembrança dos velhos. $3^{\mathrm{a}}$ edição, São Paulo: Companhia das Letras, 1994;

- BRANDAO, Carlos Rodrigues. A Cultura na rua. Campinas, editora Papirus, 1989;

Fundação Nacional da Arte, 1978; O Divino, o Santo e a Senhora. Rio de Janeiro: . Caipiras de São Paulo. São Paulo, Brasiliense, 1983; 
- BRAUDEL, Fernand. Escritos Sobre a História. São Paulo: Editora Perspectiva, $2^{\mathrm{a}}$ edição 1992;

- BRENDA, Carranza. Renovação carismática católica : origens, mudanças e tendências. Aparecida, SP : Santuário, 2000;

- BURKE, Peter. Cultura Popular na Idade Moderna. São Paulo: Companhia das Letras, 1989;

- . O que é história cultural? Rio de Janeiro: Jorge Zahar Editora, 2005.

- CAMPOS, Judas Tadeu. Festa do Divino Espírito Santo em São Luiz do Paraitinga: decadência ou transição? in Revista de Ciências Humanas da Universidade de Taubaté. Volume 3, número 2, páginas 23-32, jul-dez, 1997;

- CANCLINI , Néstor García. A globalização imaginada. São Paulo: Editora Iluminuras LTDA, 2003. Culturas híbridas. Estratégias para entrar e sair da modernidade. São Paulo: Edusp, $4^{\circ}$ edição, 2003;

- CANDIDO, Antonio. Os parceiros do Rio Bonito: estudo sobre o caipira paulista e a transformação dos seus meios de vida. São Paulo: Duas cidades, Edição 34, 2001;

- CASAL, Manuel Ayres de.. Corografia brasilica. Fac-simile da edição de 1817, introdução de Caio Prado Júnior. Rio de Janeiro, Imprensa Nacional, 2 volumes, 1945/1947;

- CASCUDO, Luís da Câmara. Antologia do Folclore Brasileiro. São Paulo: Martins, 1943; $-$

Global, 2001; . Đicionário do folclore brasileiro. $10^{\mathrm{a}}$ edição. São Paulo:

- CAVAlCANTI, Maria Laura Viveiros de Castro. Cultura e saber do povo: uma perspectiva antropológica. In Revista Tempo Brasileiro, número 147 - outubrodezembro 2001;

- CHAVES, Robson Belchior Oliveira. Salesópolis - Festa do Divino: das origens aos dias atuais. Dissertação de mestrado, PUC/SP, 2003;

- CHIMÈNES, Myriam. Musicologie et histoire. Frontière ou 'no man's land entre deux disciplines. In Revue de Musicologie, Tome 84, nº 01, 1998;

- Comitê Pró Associação para o Desenvolvimento Cultural e Ambiental de São Luiz do Paraitinga (org). São Luiz o ano inteiro. Taubaté: Vogal Editora, 1997;

- COSTA, Sérgio. A cultura caipira. Nosso feriado, no 5, São Luiz do Paraitinga, 2007;

- DEODATO, Livia “A cultura da fé na Folia do Divino". Caderno 2. Jornal O Estado de São Paulo, ano XXI, número 7.051, 14 de maio de 2007;

- DIAMOND, Jared. Armas, germes e aço: os destinos das sociedades humanas. Rio de Janeiro : Record, 2001;

- DUVIGNAUD, Jean. Festas e civilizações. Fortaleza: Universidade Federal do Ceará/ Tempo Brasileiro, 1983;

São Paulo: Centauro, 2004;

Introdução in HALBWACHS, Maurice. A memória coletiva.

- ETZEL, Eduardo. Divino. Simbolismo no folclore e na arte popular. São Paulo: Giordano, 1995;

- FALCÃO, Joaquim. Patrimônio imaterial: um sistema sustentável de proteção. In Revista Tempo Brasileiro, número 147. Rio de Janeiro, outubro/dezembro 20001;

- FARIA, Teresinha Paiva de.(org). "Decadência do café numa comunidade valeparaibana". $1^{\circ}$ Simpósio de História do Vale do Paraíba. Guaratinguetá: Faculdade Salesiana de Filosofia, Ciências e Letras de Lorena, 1973;

- FAUSTO, Boris. Historia Concisa do Brasil. São Paulo: Editora da Universidade de São Paulo, Imprensa Oficial do Estado, 2001; 
- FERREIRA, Maria Nazareth (org) A tradição e seu significado para o turismo cultural: o vale do Paraíba. São Paulo: CELACC, 1999;

- FLORENÇANO, Paulo Camilher. A Festa do Divino Espírito Santo. Taubaté. Museu e Arquivo Histórico de Taubaté, mimeografado, (1985), apud CAMPOS, Judas Tadeu. Festa do Divino Espírito Santo em São Luiz do Paraitinga: decadência ou transição? in Revista de Ciências Humanas da Universidade de Taubaté. Volume 3, número 2, páginas 23-32, jul-dez, 1997.

- FRAZER, James. O ramo de ouro. Rio de Janeiro: Guanabara Koogan, 1982;

- FRY, Peter. Para inglês ver: identidade e política na cultura brasileira. Rio de Janeiro: Zahar, 1982.

- FUKUYAMA, Francis. Fim da historia e o último homem. Rio de Janeiro : Rocco, 1992;

- GINZBURG, Carlo. Mitos, emblemas, sinais: morfologia e história. São Paulo: Companhia das Letras, 1989;

. O queijo e os vermes. São Paulo, Companhia das Letras, 1987;

- GOUVÊA, Tânia Moradei GARCIA, Patrícia Lombardi. Os arquétipos do sagrado na alegoria da Festa do Divino Espírito Santo de São Luiz do Paraitinga, Taubaté, UNITAU, 1995;

- GROS, Fréderic. (org). Foucault a coragem da verdade. São Paulo: Parábola Editorial, 2004;

- GUARINELLO, Norberto Luiz. Festa, trabalho e cotidiano in JANCSÓ, Istvan; KANTOR, Íris (org) Festa: cultura e sociabilidade na América Portuguesa. São Paulo: Hucitec: Edusp: Imprensa Oficial: Fapesp, 2001;

- GUERRA, Abílio. Carnaval caipira em São Luiz do Paraitinga. Chuva, suor, cerveja e chita. In Revista eletrônica Minha Cidade, número 178, fevereiro de 2007;

- GUIMENEZ, Denis Maracci. São Luiz do Paraitinga por ele mesmo: aspectos históricos, tradição e cultura. IN FERREIRA, Maria Nazareth (org) A tradição e seu significado para o turismo cultural: o vale do Paraíba. São Paulo: CELACC, 1999;

- HALBWACHS, Maurice. A memória coletiva. São Paulo: Centauro, 2004;

- HAVELOCK, Eric A. A Revolução da Escrita na Grécia, São Paulo: Unesp; Rio de Janeiro: Paz e Terra, 1996;

- HOBSBAWM, E. J. Sobre história : ensaios. São Paulo : Companhia das Letras, 2007.

- HOLANDA, Sérgio Buarque (org). História Geral da Civilização Brasileira. Difusão Européia do Livro, São Paulo, 1967, Tomo 2, $2^{\circ}$ volume;

- IKEDA, T. Alberto; PELLEGRINI FILHO. Américo. Celebrações populares paulistas: do sagrado ao profano in SETUBAL, Maria Alice (org). Terra Paulista: manifestações artísticas e celebrações populares no Estado de São Paulo. São Paulo: Imprensa Oficial, 2004.

- Música na terra paulista: da viola caipira à guitarra elétrica. in SETUBAL, Maria Alice (org). Terra Paulista: manifestações artísticas e celebrações populares no Estado de São Paulo. São Paulo: Imprensa Oficial, 2004.

- JANCSÓ, Istvan; KANTOR, Íris (org) Festa: cultura e sociabilidade na América Portuguesa. São Paulo: Hucitec: Edusp: Imprensa Oficial: Fapesp, 2001.

- KUGEL, SETH. "Carnaval on a Smaller Stage". The New York Times, January 27, 2008: http://travel.nytimes.com/2008/01/27//travel/27journeys.html;

- LARAIA, Roque de Barros. Cultura: um conceito antropológico. Rio de Janeiro: Jorge Zahar, 2004;

- LE GOFF, Jaques. História e Memória. Campinas, 4a edição, Campinas: Unicamp, 1996; 
Prefácio in BLOCH, Marc. Introdução à História. Publicações

Europa-América LTDA, Portugal, 2007

- LIBÂNEO, José Carlos. Profissão professor ou adeus professora? Exigências educacionais contemporâneas e novas atitudes docentes in Adeus professo adeus professora. Editora Cortez, São Paulo, 1998;

- LINS, Sivia Queiroz Ferreira Barreto. De tropas, trilhos e tatus: arredores paulistanos do auge das tropas de muares à instalação das estradas de ferro. Tese de doutoramento apresentado ao programa de história social da Universidade de São Paulo, 2003;

- LOBATO, Monteiro. Cidades Mortas. Editora Brasiliense, São Paulo, 1977;

- LOWENTHAL, David. Como conhecemos o passado. In Revista do Programa de Estudos Pós Graduados em História do Departamento de História: Projeto História trabalhos de memória. São Paulo, número 17, novembro de 1998;

New York, 2003.

- LUNA, Francisco Vidal; COSTA, Iraci del Nero. Minas Colonial: economia e sociedade. São Paulo: Fipe: Pioneira, s/d [1973];

- LUPI, João. As festas do Divino Espírito Santo. Apud CHAVES, Robson Belchior Oliveira. Salesópolis - Festa do Divino: das origens aos dias atuais. Dissertação de mestrado, PUC/SP, 2003.

- MAIA, Tom; MAIA, Thereza Regina de Campos Maia. O folclore das tropas, tropeiros e cargueiros no Vale do Paraíba. Rio de Janeiro: Funarte: Instituto Nacional do Folclore: São Paulo: Secretaria do Estado da Cultura: Universidade de Taubaté, 1981;

- MAIA, Tom e HOLLANDA, Sérgio Buarque. Vale do Paraíba, velhas fazendas. São Paulo, Cia Editora Nacional e Editora da Universidade de São Paulo, 1975;

- MALLORY, J. P. In search of the Indo-Europeans : language, archaeology and myth. London : Thames and Hudson, 1999;

- MARCONDES, Renato Leite. A arte de acumular na economia cafeeira: Vale do Paraíba, século XIX. Lorena: Editora Stiliano, 1998;

- MARIZ, Vasco. História da Música no Brasil. Rio de Janeiro: Editora Nova Fronteira, 2000;

- MATTA, Roberto da. A casa \& e a rua. Rio de Janeiro: Rocco, 1997;

- _. Carnavais, malandros e heróis: para uma sociologia do dilema brasileiro. Rio de Janeiro: Rocco, 1997.

- MATTOS IBIAPINA, Júlio de. O Brasil de ontem e o de hoje. [Rio de Janeiro]: Departamento de imprensa e propaganda, 1942;

- MAUSS, Marcel. Ensaio sobre a dádiva: forma e razão da troca nas sociedades arcaicas in Sociologia e Antropologia- volume II Edusp, São Paulo, 1993;

; HUBERT, Henri. Sobre o sacrifício. São Paulo: Corac Naify, 2005.

- MEHYI, José Carlos Sebe Bom. Manual de História Oral. Edições Loyola, São Paulo, Brasil, $4^{\mathrm{a}}$ edição, maio de 2002;

- MELERO, Margareth Yayo Gimbo Melero. Cidades mortas, passado e presente vivo: a conservação da memória em São José do Barreiro. Dissertação de mestrado, São Paulo FFLCH-USP, 2000;

- MICELI, Paulo. O ponto onde estamos: viagens e viajantes na história da expansão da conquista. (Portugal séculos XV e XVI). São Paulo, Editora Página Aberta, 1994;

- MILLIET, Sérgio. Roteiro do Café e outros ensaios. Bispa Editorial, São Paulo, 1946;

- MORAES, José Geraldo Vinci de. História e música: canção popular e conhecimento histórico. In Revista Brasileira de História, São Paulo, volume 20, número 39, página 203-221, 2000; 
- MOURA, Américo Brasiliense A. de. Governo de Morgado de Matheus no vice Reinado do Conde da Cunha, in Revista do Arquivo Municipal de São Paulo, vol. LII, SP, 1938;

- MOURA, Carlos Eugênio Marcondes de. O Visconde de Guaratinguetá- um fazendeiro de café no vale do Paraíba. São Paulo, Studio Nobel, 2002;

- MULLER, Nice Lecocq. O fato urbano na bacia do Paraíba do Sul. Rio de Janeiro: Fundação IBGE, 1969;

- MURTA, Stela Maria; ALBANO, Celina (org). Interpretar o patrimônio: um exercício de olhar. Belo Horizonte: Editora UFMG: Território Brasileiro, 2002;

- NETO, Pedro Ribeiro Moreira Fotografia e Histórias de vida- famílias caipiras do Alto Vale do Paraíba. Tese de Doutorado, São Paulo FFLCH-USP, 2002;

- OLIVEIRA, J. T. História do Café no Brasil e no Mundo. Livraria Kosmos Editora LTDA, Rio de Janeiro, 1984;

- OLIVEIRA, Maria Alice Oliva. Espaço, tempo e memória: construção $e$ transformação do espaço em São Luiz do Paraitinga e Natividade da Serra. Dissertação de mestrado, São Paulo FFLCH-USP, 2000;

- OLIVEN, Ruben George. A elaboração dos símbolos nacionais na cultura brasileira. In Revista de Antopologia. São Paulo, v26, 1983 ;

- ORTIZ, Renato. Românticos e folcloristas. São Paulo, Editora Olho dágua. 1997;

- PEREIRA, João Baptista Borges. Negro e cultura negra no Brasil atual. In Revista de Antropologia. São Paulo, vol 26, 1983.

- PERNIOLA, Mário. Pensando o ritual: sexualidade, morte e mundo. São Paulo: Estúdio Nobel, 2000;

- PETRONE, Pasquale. A região de São Luiz do Paraitinga (Estudo de geografia humana) in Revista Brasileira de Geografia, ano XXI, julho-setembro de 1959;

- PIERUCCI, Antonio Flávio. Bye, bye Brasil - o declínio das religiões tradicionais no Censo 2000 in Dossiê Religiões no Brasil, Revista do Instituto dos Estudos Avançados da USP, número 52. São Paulo: Universidade de São Paulo, 2004;

- PRADO JUNIOR, Caio. História Econômica do Brasil. 43 edição - São Paulo: Brasiliense, 1998;

- PRIORE, Mary Del. Festas e Utopias no Brasil Colonial. São Paulo, Brasiliense, 1994;

- QUEIROZ, Maria Isaura Pereira de. Carnaval brasileiro: o vivido e o mito. São Paulo, Brasiliense, 1992;

- QUEIRÓZ, Renato da Silva. Migração e metamorfose de um mito brasileiro: o saci, trickster da cultura caipira in Revista do Instituto de Estudos Brasileiros n ${ }^{\circ} 38$. São Paulo: Instituto dos Estudos Brasileiros da Universidade de São Paulo, 1995;

- RAVELI, Flávia Albergaria. A reforma ultramontana e a Festa do Divino - São Luiz do Paraitinga entre os séculos XIX e XX. Dissertação de Mestrado, São Paulo, FFLCHUSP, 1999;

- REIS, João José. A morte é uma festa: ritos fúnebres e revolta popular no Brasil do século XIX. São Paulo: Companhia das Letras, 1991;

- REVEL, Jacques. A invenção da sociedade.. Rio de Janeiro: Editora Bertrand Brasil S.A., 1989;

- RICCI, Fábio. Origens e aspectos do desenvolvimento das indústrias têxteis no vale do Paraíba na República Velha. Tese de doutorado, São Paulo FFLCH-USP, 2002;

- RUSSEL, Bertrand. História da Filosofia Ocidental. São Paulo: Companhia Editora Nacional, 1969;

- SAIA, Luiz. No caminho do Paraitinga in São Luiz do Paraitinga Publicação $n^{o}: 2$, CONDEPHAAT. Governo do Estado de São Paulo: São Paulo, 1977; 
- SAINT-HILAIRE. A viagem à província de São Paulo. São Paulo: Edusp. Belo Horizonte: Itatiaia, 1976;

- SANTOS, Carlos Murilo Prado. O reencantamento das cidades: tempo e espaço na memória do patrimônio cultural de São Luiz do Paraitinga/SP. Dissertação de mestrado. Universidade Estadual de Campinas, Instituto de Geociências, 2006;

- SENA, Maria de Fátima Alves. QUEIROZ, Odaléia T. M. M.. Impactos ambientais e sócio-culturais do turismo de segunda residência: o caso de Ponta da Tulha, Ilhéus, BA. Caderno Virtual de Turismo ISSN:1677 - 6976 Vol. 6, N 4 (2006).

- SEVCENKO, Nicolau. A corrida para o século XXI. No loop da montanha russa. São Paulo: Companhia das Letras, 2001;

- SCHMIDT, Carlos Borges. A vida rural no Brasil: a área do Paraitinga, uma amostra representativa. São Paulo, Secretaria da Agricultura do Estado de São Paulo, 1954;

- SILVA, Rita de Cássia. Entre o velho e o novo - A festa do Divino Espírito Santo de Anhembi. Mestrado em Ciências Sociais, PUC/SP, São Paulo, 2003;

- SIMÃO, Voigt. Vocabulário de Teologia Bíblica. Petrópolis/RJ, Vozes, 1999.

- SOUKEF JUNIOR, Antonio. A ferrovia e a cidade : a experiência de Bauru. Tese FAU - FAC ARQ URBANISMO -USP, 2005;

- SOUZA, Laura de Mello. O diabo e a terra de Santa Cruz: feitiçaria e religiosidade popular no Brasil Colonial. São Paulo: 1986, Companhia das Letras ;

- SOUZA, Marina de MELLO. História, mito e identidade nas festas de Reis negros no Brasil- séculos XVIII e XIX. In JANCSÓ, Istvan; KANTOR, Íris (org) Festa: cultura e sociabilidade na América Portuguesa. São Paulo: Hucitec: Edusp: Imprensa Oficial: Fapesp, 2001;

UFRJ/ Tempo Brasileiro, 1994;

.Parati: a cidade e as festas. Rio de Janeiro: Editora Patrimônio imaterial, turismo cultural e identidade nacional uma tentativa de refletir acerca de Parati. Revista Tempo Brasileiro, número 147 - outubro-dezembro 2001;

Reis Negros no Brasil Escravista: história da festa e coroação do Rei Congo. Belo Horizonte: Editora UFMG, 2002;

- STEINER, George. Origens Douradoras. In Lições de Mestres. Editora Record, Rio de Janeiro, 2005;

- TINHORÃO, José Ramos. As festas no Brasil Colonial. São Paulo, editora 34, 2000;

- TOLEDO, Marcelo Henrique Santos. Espaços individuais e coletivos da sacralidade nos meios populares. Dissertação de mestrado apresentada ao departamento de Ciências da Religião da PUC-SP. São Paulo, 2001;

- THOMSON, Alistair. Recompondo a memória: questões sobre a relação entre a História Oral e as memórias in Projeto História: Revista do Programa de Estudos PósGraduados em História e do Departamento de História da PUC-SP (Pontifícia Universidade Católica de São Paulo). São Paulo, no 15, abril de 1997;

- TRINDADE, Jaelson Bitran. No caminho do Paraitinga in São Luiz do Paraitinga Publicação $n^{\circ} 02$ - Conselho de Defesa do Patrimônio Histórico Arqueológico, Artístico e Turístico do Estado - Condephaat. Secretaria da Cultura, Ciência e Tecnologia do Governo do Estado de São Paulo, 1977;

- VALVERDE, Orlando. Estudos de Geografia Agrária Brasileira. Editora Vozes, Petrópolis, 1985;

- VARZEA, V. Vocabulário de Teologia Bíblica. Petrópolis/RJ, Vozes, 1999;

- VELASCO, Juan Martín. Metamorfosis de lo sagrado e futuro do cristianismo. Cuadernos aqui y ahora 37. Santander: Sal Terrae., 1999. 
- WERNET, Augustin. A Igreja Paulista no século XIX - a reforma de D. Antônio Joaquim de Melo (1851-1861). São Paulo, Editora Ática, 1987;

- WILLWEMS, Emílio. Cunha - Tradição e Transição em uma cultura rural do Brasil. São Paulo: Sec. De a Agricultura do Estado, 1947. 


\section{$\underline{\text { Anexos }}$}

\section{$\underline{\text { I- Cd de áudio contendo as cancões para consulta: }}$}

FAIXA 1- Canto Folia do Divino de São Luiz do Paraitinga- mestre Dito Geraldo Registro de 1984 recolhido por Benedito Galvão Frade Junior

- gravação artesanal

FAIXA 2- Fulia ( Mestre Luiz de Catuçaba); - Cai sereno na rama da mandioquinha (Elpídio dos Santos e Conde)

- CD remasterizado do LP "Chora Viola Canta Coração" -Grupo Paranga, 1981;

FAIXA 3- Viva Santos Reis (adaptação Ricardo Vignini e Alex Mathias)

- CD "Festeiro" -Grupo matuto Moderno, 2002. 


\section{II- Cópia do Programa da festa do Divino mais antigo preservado até então em São Luiz do Paraitinga (ano de 1916) Acervo pessoal de Dona Didi Andrade}






\title{
III - Transcricão do Programa da Festa do Divino de 1916
}

\author{
(IMAGEM) \\ FESTA DO DIVINO ESPIRITO SANTO \\ Da \\ Parochia de São Luiz do Parahytinga \\ PROGRAMMA
}

SABBADO 16- Ás 17 horas, terá lugar o encontro da Bandeira do Divio Espírito Santo na chácara do Sr. Pedro Alves Ferreira. Funccionaráno acto a corporação musical $S^{a}$ Cecília.

DOMINGO 17- Ás 16 horas, haverá septenário, findo, sahirá a alvorada com a Bandeira do Divino. Funcciona acto a corporação musical SS. Sacramento.

SEGUNDA FEIRA 18- Ás 18 horas, septenário e alvorada com a Bandeira do Divino que percorrerá as ruas de costume precedida da corporação musical $\mathrm{S}^{\mathrm{a}}$ Cecília.

TERÇA FEIRA 19- Ás 18 horas, septenário, e alvorada com a Bandeira do Divino. Funccionará acto a corporação musical SS. Sacramento.

QUARTA FEIRA 20- Ás 18 horas, septenário e alvorada com a Bandeira do Divino que funccionando a corporação musical $S^{a}$ Cecília.

QUINTA FEIRA 21- Ás 10 horas, almoço aos presos da Cadeia Pública. As 16 horas, jantar aos mesmos. Ás 18 horas, septenário, e alvorada acompanhada pela corporação musical SS. Sacramento.

SEXTA FEIRA 22 - Ás 10 horas, almoço aos presos da Cadeia Pública. As 15 horas, encontro do exmo.revdmo. monsenhor Antonio Nascimento Nascimento Castro, Vigário Geral desta Diocese, que vem a esta cidade pregar o sermão do Divino Espírito Santo. Funcciona a corporação musical $S^{a}$ Cecília. As 16 horas jantar aos presos da Cadeia. As 18 horas septenario. Em seguida dar-se-a inicio ao leilão de prendas em benefício da festa. Será leiloeiro o $\mathbf{s}$. Tenente José Ephigenio das Chagas. Funcciona a corporação musical $S^{a}$ Cecília
SABBADO 23 - Ás 5 horas, matinais, sendo nessa occasiao queimada uma salva de 21 tiros. As 10 horas almoço aos presos da Cadeia. As 14 horas, terá lugar a tradicional procissão do mastro; funccionando a corporação musical SS Sacramento. As 18 horas Septenário, tomando parte a jantar aos presos da Cadeia. As 18 horas septenario corporação musical SS Sacramento. Terminado que seja, haverá leilão de prendas. Antes de ser queimada a tradicional fogueira, serão exhibidas ao publico varias peças e foguetes de cores, funccionando a corporação musical Santa Cecília.

DOMINGO 24- As 5 horas, matinais sendo nessa occasiao queimada uma bateria de 21 tiros no Largo da Matriz. As 10 horas será cantada Missa Solenne. Toma parte nesse acto religioso a orchestra da corporação musical Santa Cecília regida pelo Sr. Odulpho Rodrigues de Andrade. Ao Evangelho, sermão pelo conhecido e talentoso tribuno sacro, Monsenhor, Antonio Nascimento Castro que fará houvir mais uma vez nesta cidade, as suas palavras cientificas referentes ao acto.

O harmonioso solo ao pregador será cantado pela exm ${ }^{\mathrm{a}}$. Sra . d. Luiza de Castro Moura. Terminada a missa, um nando precatório de gentis senhoritas percorrerá com a bandeira do Divino Espírito Santo, as ruas de costume acompanhado da corporação musical SS. Sacramento esmolando em beneficio da festa. As 14 horas, terá lugar o leilão de criações. A corporação musical Santa Cecília funcionará neste acto. As 16 horas, sahirá a solenne procissão do Divino Espírito Santo, que percorrerá as principaes ruas da cidade, finda a qual terá lugar o encerramento dos festejos religiosos com a benção do S.S. Sacramento, funccionando a corporação musical SS Sacramento.

Á noite, haverá leilão de prendas, tocando a corporação musical SS Sacramento.

\section{Sabbado e domingo, ás 22 horas, sahira à rua o impagável João Paulino, typo tradicional destas festas.}

Para os leiloes que se effectuarão em beneficio das despesas da festa, o festeiro, espera que lhe sejam enviadas as necessárias prendas.

Para que as solenidades religiosas a se affectuar tenham completo exito e o brilhantismo preciso, o festeiro, abaixo assignado, solicita o valioso concurso de todas as irmandades religiosas da parochia, e bem assim, convida não só ao povo desta cidade e município como também ao das cidades e localidades visinhas, para comparecer ás mesmas.

S. Luiz do Parahytinga, 20 de agosto de 1916. O FESTEIRO

José Bernardino de Castro. 


\section{IV - Mapa do percurso da Folia luizense}

Mapa dos bairros das cidades vizinhas desenhado por Odilon Bonafé: o mapa de arrcadação da folia do Divino de São Luiz do Paraitinga.

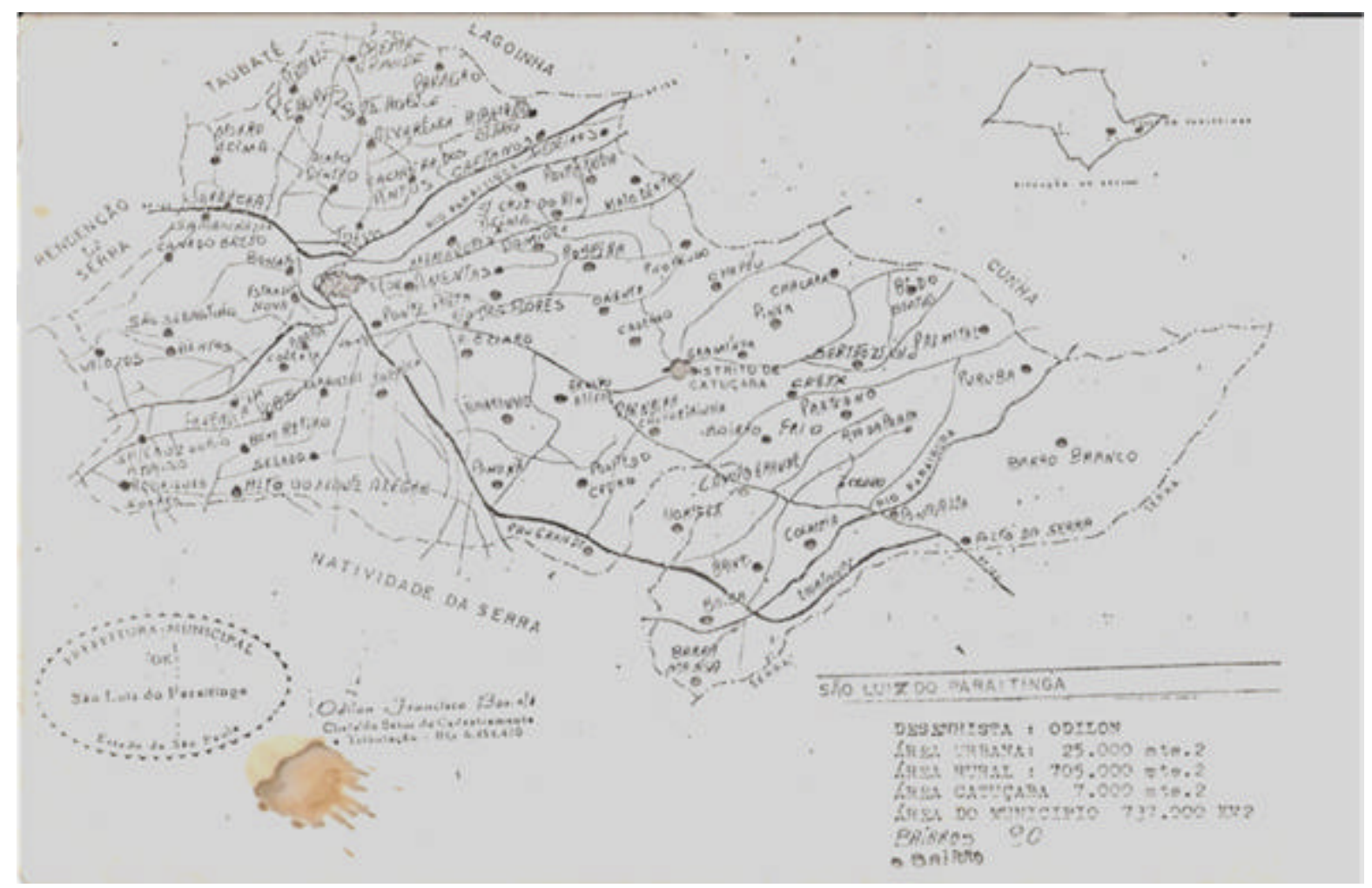




\section{$\underline{\text { V - Localização do município luizense }}$}

Mapa de localização do município de São Luiz do Paraitinga:



Fonte: www.saoluizdoparaitinga.sp.gov.br 